UNIVERSIDADE DE SÃO PAULO

FACULDADE DE FILOSOFIA, LETRAS E CIÊNCIAS HUMANAS

DEPARTAMENTO DE LINGÜÍSTICA

PROGRAMA DE PÓS-GRADUAÇÃO EM SEMIÓTICA E LINGÜÍSTICA

LEANDRO DE OLIVEIRA NERIS

Leituras escolares de um texto literário: a relação éthos/páthos no discurso 


\author{
UNIVERSIDADE DE SÃO PAULO \\ FACULDADE DE FILOSOFIA, LETRAS E CIÊNCIAS HUMANAS \\ DEPARTAMENTO DE LINGÜÍSTICA \\ PROGRAMA DE PÓS-GRADUAÇÃO EM SEMIÓTICA E LINGÜÍSTICA
}

\title{
Leituras escolares de um texto literário: a relação éthos/páthos no discurso
}

Leandro de Oliveira Neris

\begin{abstract}
Dissertação apresentada ao Programa de Pós-Graduação em Lingüística do Departamento de Lingüística da Faculdade de Filosofia, Letras e Ciências Humanas da Universidade de São Paulo para a obtenção do título de Mestre em Semiótica e Lingüística Geral.

Área de Concentração: Semiótica e Lingüística Geral
\end{abstract}

Orientadora: Profa. Dra. Norma Discini de Campos

São Paulo

2007 


\title{
Leituras escolares de um texto literário: a relação éthos/páthos no discurso
}

\author{
Dissertação apresentada ao Programa de Pós-Graduação em \\ Lingüística do Departamento de Lingüística da Faculdade de Filosofia, \\ Letras e Ciências Humanas da Universidade de São Paulo para a \\ obtenção do título de Mestre em Semiótica e Lingüística Geral. \\ Área de Concentração: Semiótica e Lingüística Geral
}

\section{Banca Examinadora}

Presidente: Prof ${ }^{\mathrm{a}}$. Dr ${ }^{\mathrm{a}}$. Norma Discini de Campos

Universidade de São Paulo

Titular: Prof. Dr. José Luiz Fiorin

Universidade de São Paulo

Titular: Prof. Dr. Arnaldo Cortina

Universidade Estadual Paulista (Unesp/Araraquara) 
Ao Wiliam, pelo o que ele representa na vida que compartilhamos juntos.

A meus pais, Waldemar e Cleusa, pela luta diária, pela valorização dada aos estudos e, principalmente, por minha constituição como ser humano. 


\section{AGRADECIMENTOS}

-A Norma Discini de Campos, que me orientou com extrema competência e seriedade, mostrando sempre o melhor caminho a percorrer;

-Ao CNPq, pela bolsa concedida para o desenvolvimento satisfatório desta pesquisa;

-A minha amiga especial Dayse, com quem compartilhei não só momentos de discussão teórica, mas também uma importante parte de minha vida;

-A Dezilda (mãe da Dayse), que sempre me acolheu como um filho em sua casa;

-Ao meu amigo Alexandre Mendes, pelo apoio disponibilizado durante a confecção deste trabalho;

-Aos meus amigos de mestrado, pelo bom convívio acadêmico. 
Eis então que o (romancista) desencadeia em nós, durante uma hora, todas as venturas e todas as desgraças possiveis, algumas das quais levaríamos anos para conhecer na vida, e outras as mais intensas dentre elas, jamais nos seriam reveladas, pois a lentidão com que se processam nos impede de as perceber (assim muda nosso coração, na vida, e esta é a mais amarga das dores; mas é uma dor que só conhecemos pela leitura).

MARCEL PROUST 
NERIS, L.O. Leituras escolares de um texto literário: a relação éthos/páthos no discurso. $184 \mathrm{f}$. Dissertação (Mestrado em Lingüística). Faculdade de Filosofia, Letras e Ciências Humanas (FFLCH) - Universidade de São Paulo (USP). São Paulo, 2007.

\section{$\underline{\text { RESUMO }}$}

Dentre os postulados metodológicos da teoria semiótica, os pontos de discussão que se apresentam como fundamentais nesta pesquisa são aqueles ligados às questões de leitura e interpretação de textos. A fim de estudar tais concepções baseadas no construto teóricometodológico da semiótica, temos como ponto de partida um corpus constituído de duas totalidades textuais. A primeira, composta de quatro contos literários do escritor norte-americano O. Henry e a segunda, formada por vinte e cinco textos interpretativos de alunos de uma classe da $3^{\mathrm{a}}$. série do ensino médio. Tais produções escolares foram elaboradas a partir do conto $O$ presente dos magos, considerado uma unidade que participa datotalidade literária em questão.

Ao colocar em cotejo essas duas totalidades, averiguamos, no movimento de leitura e interpretação, como a interioridade - as estruturas dos textos interpretativos - foi concebida em função de uma outra interioridade - as estruturas do conto literário, já que a produção interpretativa é sustentada no texto que lhe deu origem.

Do discurso literário, portanto, depreendemos dos contos de O. Henry as recorrências de um modo de dizer, a partir do que é dito. Essa análise nos permitiu verificar a imagem de um enunciatário cooperativo, com a competência para saber ler implícitos, um enunciatário (páthos) cético que incorpora o éthos cético do enunciador dos contos. Da totalidade escolar, por sua vez, reconstruímos, por meio de um exame da recorrência do fazer interpretativo dos alunos, uma imagem (éthos) de leitor e intérprete escolar erigida dos próprios textos dos sujeitos leitores.

Revela-se, pelo movimento analítico empreendido nas duas totalidades textuais, em última instância, um éthos escolar responsivo, que dialoga com a imagem do leitor (páthos) inscrito no texto literário. Nessa esteira, encaminhamo-nos em busca das relações que o éthos do leitor escolar entretêm com o páthos inscrito no texto-base para leitura.

Palavras-chave: semiótica, leitura, éthos, páthos, texto interpretativo. 
NERIS, L.O. School readings of a literary text: the ethos/pathos relation in the discourse. $184 \mathrm{f}$.

Dissertation (Master Degree in Linguistics). Faculdade de Filosofia, Letras e Ciências Humanas (FFLCH) - Universidade de São Paulo (USP). São Paulo, 2007.

\begin{abstract}
$\underline{\text { ABSTRACT }}$
Among the methodological concepts from semiotics, the discussion points considered as fundamental in this research are those related to the reading and interpretation process. To study these concepts based on the theoretical and methodological paradigm of semiotics, we have as a starting-point a corpus formed by two textual totalities: one, composed by four literary short stories by $\mathrm{O}$. Henry and the other, formed by twenty-five interpretative texts written by students of the $3^{\text {rd }}$ high school grade of a public school. The students' texts were created from The Gift of the Magi short story, considered as a unit that participates of the literary totality.

Relating and comparing these two totalities, we could verify as the interiority of the school texts were founded because of the structures of the literary short story, since the interpretative production is supported by the text that gave origin to it.

From the literary discourse, we could deduce from O. Henry's short stories the recurrences of a way of saying from what is said. This analysis permitted us to verify the image of a cooperative enunciatee with the competence to know how to read implicits, a skeptical enunciatee (pathos) that incorporates the enunciator's skeptical ethos instituted in the short stories. From the school totality, we reconstructed a school reader's image (ethos) erected from the students' texts by the exam of the interpretative doing recurrences.

It was revealed, at last, by the analytical movement executed in the two totalities, a responsive school ethos that dialogues with the reader's image (pathos) established by the literary text. Thus, we are conducted to observe the relations that the school reader's ethos maintain with the pathos instituted in the short story by O. Henry.
\end{abstract}

Keywords: Semiotics, reading, ethos, pathos, interpretative text. 
Capítulo I - Semiótica, leitura e texto interpretativo 15

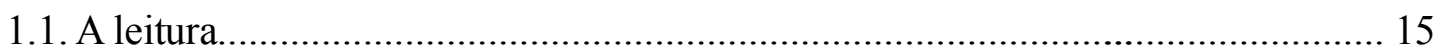

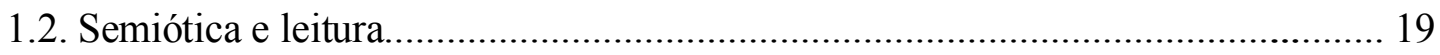

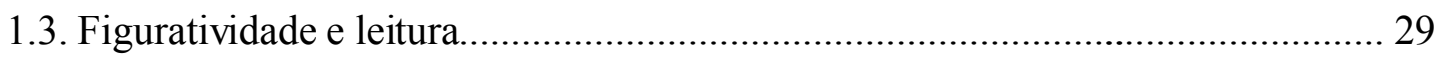

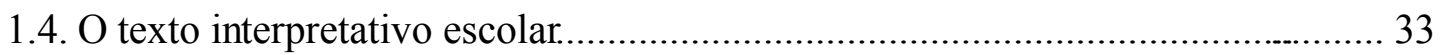

Capítulo II - Análise semiótica do conto O presente dos magos de O. Henry................ 42

2.1. Conto: O presente dos magos........................................................................... 42

2.2. Análise semiótica do conto $O$ presente dos magos .............................................. 48

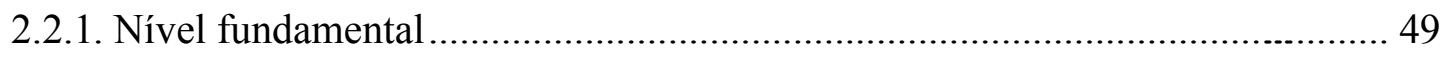

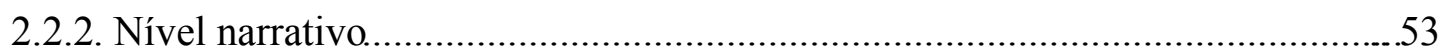

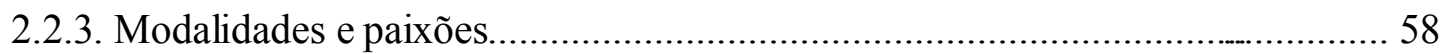

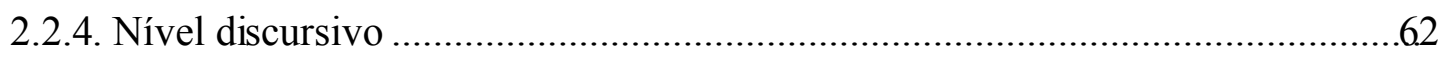

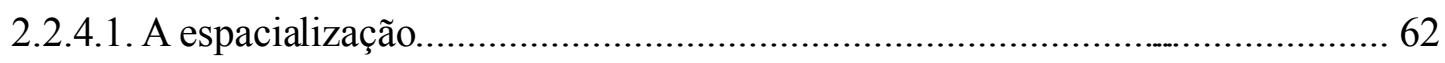

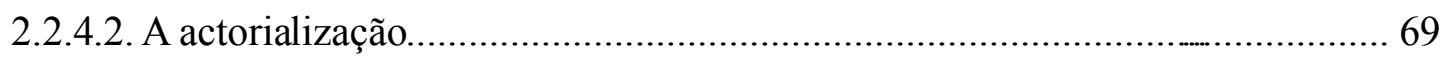

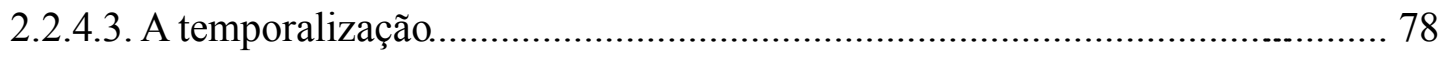

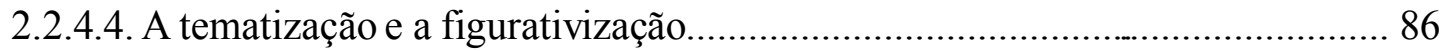

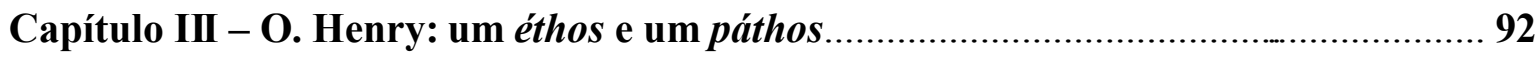

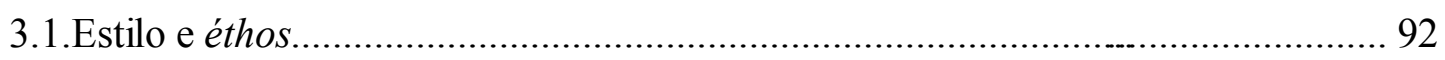

3.2. Em busca do éthos e do páthos em O. Henry ................................................... 96

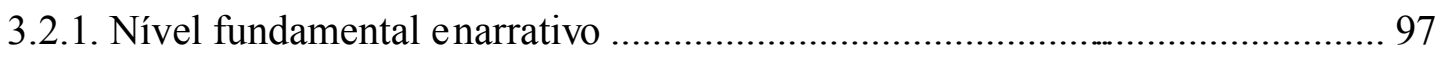

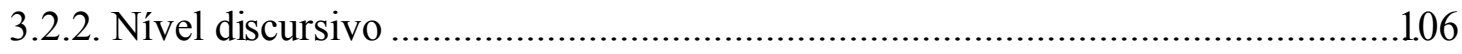

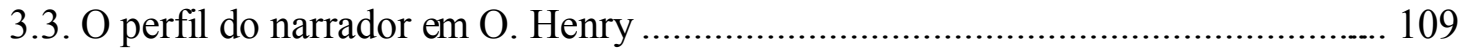

Capítulo IV - Estudo dos textos interpretativos: o éthos do leitor escolar.................... 117

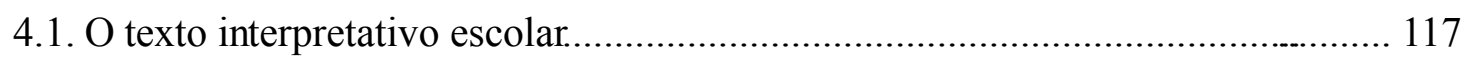

4.2. Abordagem semiótica dos textos interpretativos escolares ................................ 119

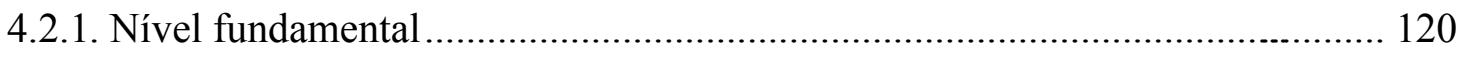

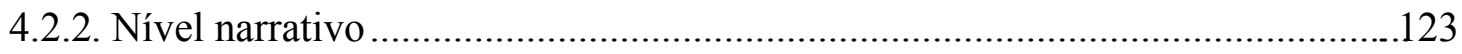




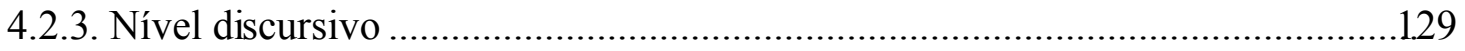

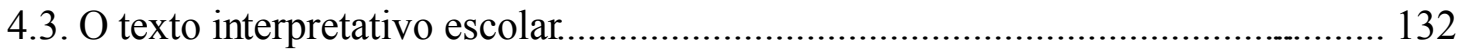

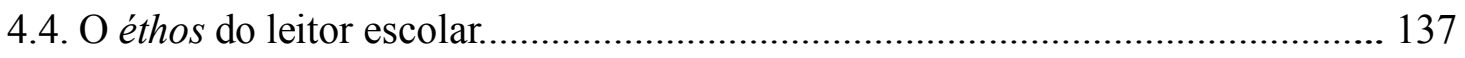

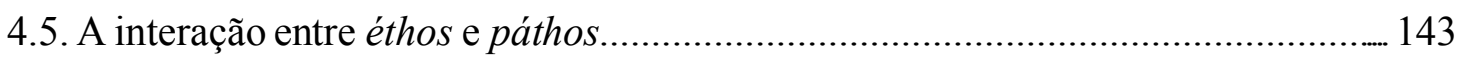

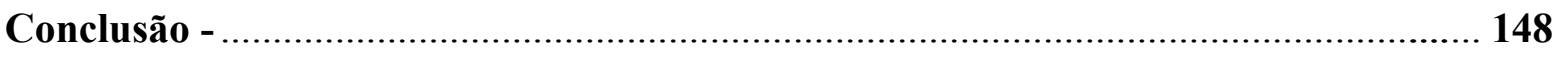

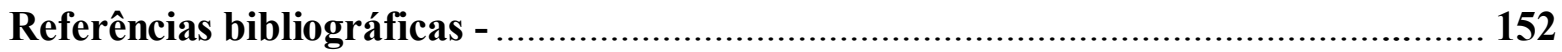

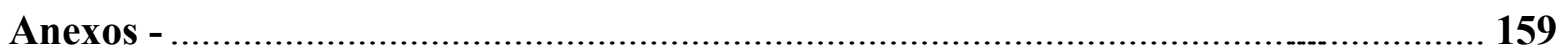

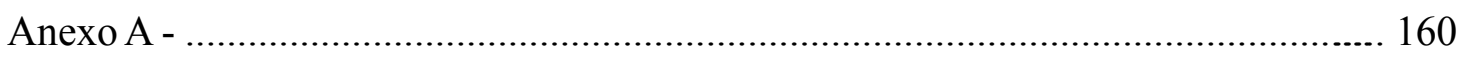

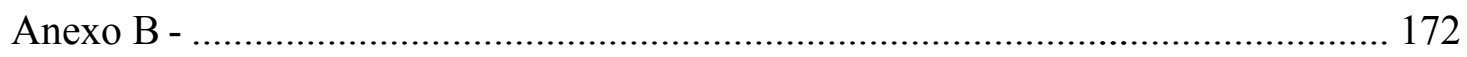




\section{Introdução}

Desenvolver um estudo relativo à leitura implica colocar o sujeito leitor e intérprete no centro de nossas preocupações e retomar inquietações importantes no que tange às competências necessárias para a capacidade de ler e interpretar. A leitura é um dos elementos que constitui o processo de produção da escrita, uma vez que fornece matéria-prima para a produção textual (o que escrever), coloca o leitor em contato com os procedimentos de organização interna do texto e contribui para a constituição de modelos (o como escrever). Cremos, dessa forma, que bons redatores precisam ter um repertório amplo de modelos ancorados em diretrizes que os guiem no processo de geração de seus textos.

Foi a partir de uma preocupação primeira com a importância da leitura no âmbito escolar e, particularmente, da necessidade da aplicação de "técnicas" de interpretação devidamente fundamentadas em um aparato teórico, em sala de aula, que nosso interesse em penetrar no universo do leitor se delineou. Como professor de Português, a constante observação do contato que os alunos tinham com os textos literários em classe já prenunciava "matéria-prima" para esta pesquisa. A relação pedagógica com um sujeito leitor empírico fez suscitar, então, a indagação que perpassa toda esta dissertação: quais as relações estabelecidas entre um texto interpretativo e um texto-fonte para leitura?

Para tentar respondê-la, tivemos que estipular parâmetros mais específicos que nos permitissem averiguar com mais controle o ato de ler e interpretar. Dessa maneira, ao optar pela teoria semiótica com sua metalinguagem descritiva e operacional, respaldamo-nos em um instrumento metodológico que possibilita chegar à constituição de um leitor inscrito no texto: o enunciatário. Esse leitor instituído e configurado por características discursivas propicia verificar princípios estruturados de interação entre texto e leitor. Assim, a confluência entre os simulacros inscritos no texto com aqueles construídos depois de uma leitura realizada apresenta-se, também, como o espaço recortado a ser pesquisado por nós.

Dessa forma, os objetivos traçados para nosso estudo seguem arrolados a seguir: 
1. verificar como e por que o texto interpretativo escolar materializa um gênero discursivo;

2. observar as relações estabelecidas com um texto-fonte, pelo leitor em situação escolar, a partir da observação de textos interpretativos escolares, promovidos como avaliação da expressão escrita em nível de ensino de segundo grau. Pretendemos averiguar, portanto, o olhar do leitor que se circunscreve à aparência textual ou o olhar que desce e busca na imanência discursiva mecanismos de construção de sentido; averiguar como o aluno produziu um texto que dialoga com o texto-fonte e as vozes convergentes e vozes divergentes do leitor em relação à voz do enunciador do conto;

3. descrever semioticamente mecanismos de construção do sentido do texto-fonte, um conto literário de $\mathrm{O}$. Henry, dado como matriz para a produção dos textos interpretativos dos alunos;

4. examinar o leitor instituído pelo texto-fonte, como feixe de estratégias enunciativas que projetam determinado conjunto de disposições e de paixões, tido como o páthos instituído pelo texto;

5. investigar, nos textos interpretativos escritos, desenvolvidos mediante proposta de interpretação do texto-fonte, mecanismos de construção de sentido da imagem do enunciador da totalidade considerada dos textos escolares. Examinar, portanto, o ator da enunciação pressuposto à totalidade dos textos interpretativos, como um modo próprio de presença no mundo, ao reagir aos apelos do texto-fonte, isto é, a imagem de si mesmo que este aluno constrói como éthos ao textualizar e discursivizar sua análise: o convicto ou o hesitante, o sujeito orientado pela paixão da indiferença, entre outras;

6. descrever e explicar como e por que o leitor previsto no texto-fonte converge para, ou diverge de um leitor dado em situação escolar de leitura: o gênero "texto interpretativo escolar", que materializa o discurso pedagógico.

Este trabalho justifica-se por propiciar reflexões teóricas que explicitem o papel da leitura diferentemente das pesquisas voltadas a um percurso histórico atrelado ao ato de ler. Julgamos necessário, portanto, desenvolver um estudo que desse conta de analisar o que se lê e como se lê, tratando de conhecer o enunciador e o enunciatário inscritos na produção do discurso.

Pensamos ser profícuo aplicar a teoria semiótica greimasiana e suas recentes descobertas para determinar questões relevantes que permeiam a leitura e a interpretação de textos literários. Temos o intuito, então, de que nossa pesquisa possa complementar para o desenvolvimento dos estudos semióticos, mais particularmente no que se refere aos estudos sobre a leitura. Poderemos, 
dessa forma, conhecer a imagem do produtor de textos interpretativos (éthos) como um éthos responsivo, que dialoga com a imagem do leitor (páthos) inscrita no texto literário. Afirmamos, pois, a justificativa deste trabalho na medida em que possa contribuir para entendermos a imagem do aluno - sujeito leitor e intérprete - e que as análises dos textos propostos não se restrinjam à confirmação da operacionalidade do uso do mesmo modelo analítico adotado.

Trabalhamos com duas totalidades textuais: uma que se refere a contos literários do escritor norte-americano O. Henry e a outra formada por textos interpretativos. Do discurso literário serão tomados quatro contos de O. Henry para que sejam depreendidas as recorrências de um modo de dizer a partir do que é dito. Ressaltamos, todavia, que os textos interpretativos foram construídos tendo como base apenas um conto do escritor, o qual intitula-se $O$ presente dos magos. Esse conto foi distribuído para uma classe da $3^{\mathrm{a}}$. série do ensino médio, contando com o número de vinte e cinco alunos, e serviu de texto-fonte para a seguinte proposição didática: "Leiam esse conto e escrevam uma interpretação a partir do que entenderam sobre ele e a partir do que sentiram ao entrar em contato com ele".

Em posse desse corpus formado por essas duas totalidades textuais, os movimentos da pesquisa orientaram-se por esta metodologia:

a) análise semiótica do texto-forte para interpretação - O presente dos magos;

b) cotejo com outros três contos do mesmo autor para buscar as invariâncias que subjazem às variações;

c) descrição dos mecanismos de construção do sentido dos textos escolares, considerados como um unus, uma unidade de sentido recortada para análise à qual corresponde, em relação de complementaridade, o totus.

d) exame do éthos e do páthos do texto-fonte, bem como dos modos de articulação do páthos instituído pelo conto com o éthos das produções escolares dadas a conhecer: convergência ou divergência?

Reafirmamos, que a linha teórica com a qual operamos fundamentalmente as análises segue o modelo da semiótica greimasiana. No entanto, apesar dos pressupostos da semiótica dominarem nosso estudo, alguns conceitos, quando pertinentes, advindos de obras de autores inseridos em outros referenciais teóricos, também foram incorporados para que pudéssemos abordar as questões de discurso, gênero e leitura com mais exatidão.

Do ponto de vista da estruturação desta dissertação, haverá uma divisão em quatro capítulos, seguidos de uma conclusão que retoma os aspectos principais discutidos ao longo do trabalho. 
No primeiro capítulo, apresentamos um olhar amplo no que concerne às questões de leitura. Abordamos diversos estudos que versam sobre diferentes concepções do leitor e do ato de ler, para que pudéssemos delimitar o campo de pesquisa que nosso trabalho abrange. Dessa forma, buscamos resgatar, dentro da conjectura teórica da semiótica, o estatuto da leitura e do leitor, expondo dois posicionamentos possíveis para o exame da leitura e tentando estabelecer um vínculo entre eles. Ainda, no mesmo capítulo, discorremos sobre a estruturação de um texto interpretativo e sua ancoragem em um gênero do discurso especificamente escolar. A explanação sobre o texto interpretativo nos permite averiguar as relações que as coerções próprias de um gênero escolar entretêm com a organização interna das produções textuais, que compõem a totalidade escolar em questão.

O segundo capítulo trata da análise semiótica efetuada do conto literário $O$ presente dos magos, texto este que serviu de texto-fonte para a coleta das interpretações escritas na escola. O trabalho analítico do conto faz-se necessário para que possamos compreender com maior clareza o movimento de leitura estabelecido pelos alunos ao discursivizar e textualizar suas interpretações. Examinamos, então, mecanismos de construção do sentido que remetem ao "fazer receptivo" do leitor, concebido como feixe de estratégias do próprio texto literário.

O terceiro capítulo, por sua vez, busca depreender o éthos e o páthos inscritos no interior dos contos literários de $\mathrm{O}$. Henry. Resgatamos mais três contos do autor, para examinar recorrências no modo de estruturar seus textos. O conto $O$ presente dos magos se constitui, então, como a peça discursiva considerada o pilar da totalidade: unidade que serelaciona de modo complementar com a totalidade.

No quarto capítulo, descrevemos e explicamos os textos interpretativos produzidos por alunos da $3^{\circ}$ série do ensino médio. Nesse ponto, mostramos o corpus coletado na escola e delimitado segundo critérios próprios. Procedemos à análise semiótica dessa totalidade textual, a fim de encontrar recorrências no modo de estruturar as produções interpretativas escolares. Nessa esteira, encaminhamo-nos em busca do éthos do leitor escolar como um reflexo e uma refração do páthos inscritos no texto-base. Poderemos deduzir, talvez, o tipo de relação éthos - páthos a partir da imagem do enunciador do conto (éthos); da imagem prevista do enunciatário no conto (páthos); da imagem do enunciador das redações escolares (éthos) - um éthos responsivo, que responde ao páthos previsto pelo conto de $\mathrm{O}$. Henry. 


\section{Capítulo I - Semiótica, leitura e texto interpretativo}

\section{1. A leitura}

Ao desenvolver um trabalho que se ocupa da leitura, devemos remontar a alguns princípios que circundam o ato de ler e reconhecer peças fundamentais que participam de sua constituição. Dessa forma, em uma primeira abordagem, podemos conceber a leitura como sendo

\footnotetext{
o reconhecimento dos grafemas (ou letras) e de sua concatenação que resulta na transformação de uma folha ornada de figuras desenhadas numa ordem manifesta de um texto. Por extensão, o termo leitura é empregado quando se fala de outras substâncias da expressão além do grafismo: a leitura táctil é praticada por cegos que se servem de livros impressos em relevo; a leitura óptica designa o deciframento dos caracteres escritos por computadores, etc (GREIMAS e COURTÉS, [1983], p. 251).
}

Observamos, a partir dessa primeira concepção, que a leitura demanda uma identificação de elementos de superfície necessária para percorrer de modo linear e coerente um texto. Assim entendida, em termos semióticos, a leitura é "essencialmente uma semiose, uma atividade primordial cujo resultado é correlacionar um conteúdo a uma expressão dada e transformar uma cadeia de expressão em uma sintagmática de signos" (GREIMAS e COURTÉS, [1983], p. 251).

Tal performance pressupõe uma competência do leitor, comparável ainda que não necessariamente idêntica, à do produtor do texto. Se, no momento da leitura, o fazer receptivo e interpretativo do enunciatário-leitor é condição necessária ao ato, a explicitação de tal ato, sob forma de procedimentos de análise estabelecidos, tendo em vista a reconstrução do sentido no enunciado tomado como base da leitura, constitui tarefa da semiótica. Nessa perspectiva, entende-se por leitura a construção, ao mesmo tempo sintáxica e semântica, do objeto semiótico que explica o texto-signo. O leitor deve possuir, ainda, um conhecimento da gramática da língua, o que implica em uma "competência léxica que concerne tanto ao significado quanto aos valores que se vinculam ao emprego dos termos" (MAINGUENEAU, 1996, p. 43). 
Julgamos necessário, então, apresentar alguns dos estudos realizados sobre o ato de ler e interpretar textos, para que possamos refletir sobre paradigmas teóricos que apontam para as múltiplas facetas que envolvem a leitura e o leitor, pois como afirma Maingueneau (1996,p. 34):

Provavelmente o mais incômodo está em o termo 'leitor' ser suscetível de usos muito variados, oscilando entre o histórico e o cognitivo. O leitor é ora o público efetivo de um texto, ora o suporte de estratégias de decifração. Os dois aspectos interpenetram-se, mas não tentam captar a mesma coisa. São pontos de vista diferentes sobre a posição da leitura.

Iniciemos falando sobre a teoria cognitivista de Smith (1999) em relação ao saber de "longo prazo". Tal saber deve ser entendido como uma organização de informações presentes na memória (pacotes de conhecimentos estruturados, acompanhados de instruções para seu uso): “A memória de longo prazo é tudo o que nós sabemos sobre o mundo, e tudo o que nós sabemos sobre o mundo está organizado" (SMITH, 1999, p. 45). Diríamos, dessa maneira, que todo leitor possui esse saber que deve ser acionado no momento da performance de leitura. Dessa forma, a capacidade de leitura atrelaria esse saber sobre o mundo a um conjunto de recursos mentais que nós mobilizamos ao ler e que é específico da atividade de leitura. Não podemos nos esquecer, contudo, de que essa capacidade gera diferentes formas de apreender o texto.

Próximo a esse pensamento, estariam os estudos desenvolvidos por Ângela Kleiman (2004b). Em seus trabalhos há uma focalização na atividade intelectual do leitor, uma vez que procura determinar os processos cognitivos que constituem a atividade em que o leitor se compromete para construir o sentido de um texto. Para tanto, a autora julga importante a necessidade de conhecimento prévio, tais como: conhecimento lingüístico, textual, de mundo, enciclopédico, que são ativados no momento da leitura. Kleiman (2004b, p.36) destaca também o aspecto individual do estabelecimento de objetivos e hipóteses.

As hipóteses do leitor fazem com que certos aspectos do processo, essenciais à compreensão, se tornem possíveis, tais como o reconhecimento global e instantâneo de palavras e frases relacionadas ao tópico, bem como inferências sobre as palavras não percebidas durante o movimento do olho durante a leitura, 
que não é linear, o que permitiria ler tudo, letra por letra e palavra por palavra, mas é sacádico, o que significa que o olho dá pulos para depois se fixar numa palavra e daí pular novamente uma série de palavras até fazer nova fixação.

Como vemos, conforme Kleiman (2004b), essa é uma atividade metacognitiva, ou seja, "atividades que pressupõem reflexão e controle consciente sobre o próprio conhecimento, sobre o próprio fazer, sobre a própria capacidade" (KLEIMAN, 2004b, p. 43-44). Estamos, portanto, no terreno da compreensão do pensamento ativado para o processo de leitura. Segundo os pressupostos para saber ler expostos acima, podemos, ainda, correlacionar o funcionamento da leitura, a um saber "fazer inferências". O estudo comentado propõe atividades que têm como objetivos a realização de deduções, associações e analogias, em que a interpretação é indissociável do texto, do contexto de enunciação, das condições de produção e recepção e dos conhecimentos prévios do sujeito.

Para Marcuschi (1985), uma das formas de entender a leitura é vê-la como um processo inferencial, ou seja, como uma operação cognitiva que possibilita ao leitor construir novas proposições a partir de outras já dadas. Dessa forma, há uma interação entre autor e leitor por meio do texto, sendo que o conhecimento de mundo, as experiências, as crenças individuais e coletivas influenciam na organização das inferências durante o ato de ler.

Marcuschi (1985) distribui o funcionamento das inferênciasem três grupos principais: a) inferências lógicas, que são aquelas realizadas por deduções imediatas; b) inferências pragmáticoculturais, que são aquelas baseadas no input textual e também no conhecimento de itens lexicais e relações semânticas; c) inferências pragmático-culturais, que são aquelas relacionadas a conhecimentos pessoais, crenças e ideologias do indivíduo. De acordo com esse modelo proposto por Marcuschi (1985), conseguimos vislumbrar os saberes necessários ao sujeito leitor para, no momento da leitura, produzir novas proposições. Seguindo essa visão inferencial, a performance de leitura preencheria por conexões lexicais ou conceituais "lacunas" apresentadas pelo texto. Dessa forma, o indivíduo é considerado capaz de rever seus esquemas, refazer hipóteses e redirecionar sua compreensão.

Mary Kato (1985), por sua vez, entendendo a leitura como um processo de decodificação, demonstra duas possibilidades de processamento da informação: a hipótese top-down ou descendente; a hipótese botton-up ou ascendente. A possibilidade ascendente prioriza o texto e os dados que há nele como ponto de partida para a compreensão; já a possibilidade descendente prioriza o leitor como fonte única de sentido, de forma que o texto serviria apenas como recurso para confirmação de hipóteses. A partir dessas duas posições diante da leitura, a autora determina, ainda, 
uma terceira possibilidade que observaria o processo de leitura, não como dependente de uma ou de outra das duas possibilidades expostas acima, mas de uma interação entre texto e leitor.

Nessa terceira concepção de leitura, o sujeito portador de esquemas mentais recrutaria seus conhecimentos prévios e os confrontaria com os dados do texto, construindo sentidos pelo ato de inferir, acionar esquemas e interagir com os dados do texto. De acordo com Kato (1985, p. 57): "o texto-produto é visto como um conjunto de pegadas a serem utilizadas para recapitular as estratégias do autore, através delas, chegar aos seus objetivos".

A Análise do Discurso (AD) considera o ato de ler como um processo discursivo no qual se inserem os sujeitos produtores de sentido - autor e leitor - ambos sócio-historicamente determinados e ideologicamente construídos. Nesse momento, o que está em questão é a leitura vista como atividade produtora de sentidos pela interação autor/leitor. Essa interação tem como lugar de efetivação o texto, entendido como materialidade, cuja organização interna implica a relação com a discursividade - o modo como elementos provindos do exterior sócio-histórico se organizam em seu interior para produzir o efeito de unidade do texto. Orlandi (1987), tendo como base para seus estudos a $\mathrm{AD}$, diz que a leitura é produzida e, portanto, é preciso que se atente para suas condições de produção.

Dessa forma, a AD considera a leitura como uma prática discursiva. O leitor ocupa um lugar de sujeito-leitor, identificado com uma formação discursiva. Assim, tal sujeito produz a sua leitura a partir de um lugar social que pode ou não coincidir com o lugar social a partir do qual o sujeito/autor produziu seu texto.

Para a Análise do Discurso, portanto, o contato com a materialidade textual requer a mobilização de uma memória discursiva (histórico de leituras, outros discursos e o contexto sóciohistórico), o que leva o leitor a interagir com o texto e desestabilizar os sentidos contidos nele (discutir, debater, argumentar). O sujeito promove, então, uma ressignificação do texto, na medida em que, ao desestabilizar seus sentidos pela produção de leitura, por meio de sua memória discursiva, reestrutura sua homogeneidade. O leitor emerge desse processo como um sujeito autor, uma vez que produz um novo texto a partir da atividade de leitura.

Todas esses desdobramentos expostos não esgotam as pesquisas que se propõem estudar o "evento", que é a leitura. Foram listadas algumas, apenas para que pudéssemos delimitar nosso escopo de estudo e orientar nossas reflexões em direção a uma abordagem semiótica da leitura. Buscamos uma visão de leitura segundo a noção de uma enunciação, enunciador/enunciatário, construídos, eles próprios, como efeito de sujeito, efeito de individuação, construídos nos e pelos textos. 


\subsection{Semiótica e leitura}

Postula-se em Semiótica que o discurso é o resultado de um fazer enunciativo, cujos componentes podem ser descritos em diferentes níveis de generalidade e complexidade. A geração do enunciado-discurso é apreendida como um percurso que vai do patamar mais simples ao mais complexo, pelo sucessivo investimento de valores semânticos sobre articulações sintáticas cada vez mais refinadas. Os níveis de descrição subordinam-se hierarquicamente uns aos outros, sendo que os mais complexos pressupõem e determinam os mais simples.

As estruturas responsáveis pela organização do sentido no plano do conteúdo dos textos constituem o que Greimas denominou percurso gerativo do sentido. A distribuição dos componentes e sub-componentes desse percurso pode servisualizada conforme o quadro seguinte:

\begin{tabular}{|c|c|c|c|}
\hline \multicolumn{3}{|c|}{ PERCURSO GERATIVO } \\
\hline \multirow{2}{*}{$\begin{array}{c}\text { Estruturas Sêmio- } \\
\text { narrativas }\end{array}$} & \multicolumn{2}{|c|}{ Componente sintático } & Componente semântico \\
\cline { 2 - 4 } & Nível profundo & $\begin{array}{c}\text { SINTAXE } \\
\text { FUNDAMENTAL }\end{array}$ & $\begin{array}{c}\text { SEMÂNTICA } \\
\text { FUNDAMENTAL }\end{array}$ \\
& Nível de superfície & $\begin{array}{c}\text { SARRATIVA DE } \\
\text { SUPERFÍCIE }\end{array}$ & SEMÂNTICA NARRATIVA \\
Estruturas & SINTAXE DISCURSIVA & SEMÂNTICA DISCURSIVA \\
Discursivas & Discursivização & Tematização \\
& \multicolumn{2}{|c|}{$\begin{array}{c}\text { Actorialização } \\
\text { Temporalização } \\
\text { Espacialização }\end{array}$} & Figurativização \\
& \multicolumn{2}{|c|}{} & \\
\hline
\end{tabular}

A teoria semiótica deve "explicitar, sob a forma de construção conceptual, as condições da apreensão e da produção do sentido" (GREIMAS e COURTÉS, [1983], p. 415). A semiótica revela então duas preocupações: uma, com a leitura, interpretação e exploração do sentido através da análise; e, numa etapa posterior, uma vez observados os mecanismos de geração textual, fornecer 
subsídios para a produção de textos verbais ou não verbais. Por meio da teoria semiótica, temos a possibilidade de enfocar os diversos níveis de significação de textos, isto é, de conjuntos significantes, explorando-os e descrevendo-os. Esses procedimentos mostram como as estruturas que compõem hierarquicamente a geração do sentido se unem à expressão para produzir a significação, ou melhor, como o sentido se transforma em significação no momento da enunciação e atinge assim o nível da textualização.

Dessa maneira, o percurso gerativo do sentido, com sua respectiva sistematização, aponta para a problemática da colocação em discurso das estruturas que compõem o plano do conteúdo dos textos e, particularmente, em um processo inverso, do reconhecimento delas no ato cognitivo de ler. Nesse sentido, torna-se necessário aproximar a teoria que desvenda a imanência dos textos da "linguagem 'em ato', apreendida em seu 'contexto' social e interacional" (LANDOWSKI, 1992, p. 145).

Adentrar, dessa maneira, no terreno da leitura e recepção de textos nos faz tentar compreender uma prática representativa de uma atividade que engloba percepção, processamento, memória, inferência e dedução. Como, então, seria possível desenvolver dentro do construto teóricometodológico da semiótica tais noções vinculadas mais aos aspectos pragmáticos da leitura em busca do "acontecimento" do ato de ler? Bertrand (2003, p. 399-400) nos dá um direcionamento possível para a compreensão do ato de leitura fundado no quadro teórico dasemiótica greimasiana.

\footnotetext{
A semiótica é sempre vista como uma teoria descritiva e explicativa, centrada, em virtude de seu princípio de imanência, somente nas relações internas do texto, ignorando assim a presença e o papel do leitor [...] Hoje procuramos menos analisar e racionalizar os diferentes níveis de articulação da significação textual, considerando alguns de seus modelos como aquisições, do que ligar a efetuação do sentido com a enunciação viva, numa interação estreita entre leitor e o texto; procuramos em suma, apreender a palavra em ato.
}

Inicialmente, somos levados a distinguir para a teoria semiótica duas posições diante da leitura: uma, que observa o leitor inscrito no texto-fonte, o texto dado à leitura, o leitor, visto pela semiótica como a figura do enunciatário; e outra, voltada para a ação, considerando o leitor como o sujeito performativo do ato deler. 
O primeiro posicionamento considera o enunciatário não como o leitor real, mas como o destinatário implícito da enunciação. São os elementos do próprio texto que proporcionam o contorno desse leitor a partir de características discursivas. Esse sujeito passa a ser, então, coenunciador de todo e qualquer texto, já que vai determinar a escolha dos elementos que irão compor a estrutura textual. Duas formas lingüísticas estão presentes, então, na enunciação: o sujeito gerador do discurso, o enunciador, e aquele para quem se dirige esse mesmo discurso, o enunciatário.

Necessário, ainda, é diferenciar enunciatário de narratário. O narratário, conforme Greimas e Courtés ([1983], p. 294) é um actante da enunciação enunciada e pode encontrar-se "em sincretismo com um dos actantes do enunciado (ou da narração), tal como o sujeito do fazer pragmático ou do sujeito cognitivo, por exemplo”. Nessa esteira, Maingueneau (1996) aponta para um leitor invocado, para o qual o texto se dirige explicitamente. Temos, dessa forma, o destinatário do discurso explicitamente instalado no enunciado (tu) como um efeito de sentido interno ao texto. O enunciatário se aproxima, por sua vez, do leitor instituído de Maingueneau (1996, p. 35), pois "será a instância que a própria enunciação do texto implica" e como posição de leitura exigida pela enunciação.

O enunciatário, manipulado cognitiva e pragmaticamente pelo enunciador, cumpre os papéis de destinatário-sujeito e o fazer pretendido mantém-se pressuposto. O fazer-interpretativo do enunciatário, que responde ao fazer persuasivo do enunciador, ocorre em qualquer texto como efeito de sentido. O leitor é, então, efeito de sentido, é arquitetura do texto. O enunciador propõe um contrato que estipula como o enunciatário deve interpretar a verdade do discurso, uma vez que marcas do texto-fonte de leitura prevêem a performance do leitor.

Ademais, o enunciatário-leitor não é apenas o destinatário da comunicação, mas também sujeito produtor do discurso, por ser a leitura um ato de linguagem (um ato de significar) da mesma maneira que a produção do texto propriamente dita. $\mathrm{O}$ enunciatário, manipulado cognitiva e pragmaticamente pelo enunciador, cumpre os papéis de destinatário sujeito, ainda que o fazer pretendido não se realize (BARROS, 2001). O fazer interpretativo do enunciatário, que responde ao fazer persuasivo do enunciador, é depreensível do discurso-enunciado. O enunciador propõe um contrato que estipula como o enunciatário deve interpretar a verdade do discurso.

A interpretação depende, assim, da aceitação do contrato fiduciário e, sem dúvida, da persuasão do enunciador para que o enunciatário encontre as marcas de veridicção do discurso e as compare com seus conhecimentos e convicções, decorrentes de outros contratos de veridicção, e creia, isto é, assuma as posições 
cognitivas formuladas pelo enunciador. $\mathrm{O}$ enunciador não produz discursos verdadeiros ou falsos, mas constrói discursos que criam efeitos de sentido de verdade ou de falsidade, que parecem verdadeiros. O parecer verdadeiro é interpretado como ser verdadeiro, a partir do contrato de veridicção assumido. (BARROS, 1988, p. 94)

Dessa forma, para explicar "o que o texto diz", a semiótica trata de examinar os procedimentos de organização textual e, ao mesmo tempo, os mecanismos enunciativos de produção e recepção do texto. Em relação a tais mecanismos, citando Maingueneau (1996, p. 32) "é o coenunciador que enuncia a partir das indicações cuja rede total constitui o texto da obra". Dessa forma, as questões relativas à enunciação nos servirão de parâmetros teóricos, uma vez que dois actantes estão presentes na enunciação narrativizada: o sujeito gerador do discurso, o enunciador, e aquele para quem se dirige esse mesmo discurso, o enunciatário, no programa narrativo de base que é a manipulação. Além disso, o perfil do leitor é concebido como feixe de estratégias inscrito no próprio texto, isto é, como imagem (páthos), depreensível do enunciadb.

O segundo posicionamento é aquele que explicita os mecanismos de recepção do texto, ou seja, o processo de leitura em ato, captando o leitor em seu fazer-interpretativo como o principal modo de funcionamento da competência epistêmica. Assim como diz Cortina (2004, p. 186), “A semiotização do ato de leitura se dá na medida em que se examina o movimento significativo instaurado pela relação entre o enunciado e o sujeito social da leitura". Desse ponto de vista, se, para a semiótica, o leitor real está fora de seu horizonte teórico, deve-se tentar apreendê-lo, "semiotizar o ato de leitura" estudando o fazer-receptivo sob a descrição semiótica.

Em semiótica, como já vimos, o estudo do leitor sempre se envereda para a descrição de um modelo homogêneo capaz de organizar as relações entre enunciador e enunciatário pautadas em um simulacro da interação entre autor e leitor. Empreende-se uma apropriação dos modelos sêmionarrativos e discursivos que possam dar suporte ao percurso de leitura realizado por um sujeito, sujeito este dotado de competências e de um fazer que delimita um desempenho realizado sob a forma de um comportamento de leitura fundado em um fazer cognitivo.

Devemos apropriar-nos, assim, do modelo metodológico da semiótica para compreender a produção e a recepção dos textos e observar mecanismos que explicam a atividade interacional de leitura. Dessa forma, em um trabalho realizado com leitura, os momentos de apreensão dos níveis de construção do sentido pelo leitor fazem-nos verificar que o componente pragmático já se encontra instituído no texto, uma vez que a própria estruturação textual já prefigura um ato empírico de ler 
por meio de uma operacionalidade leitora que se inscreve no próprio interior do texto. É fazer sair do texto um leitor dotado de competências modais que se erige em um ser de linguagem capaz de interagir com o texto.

Colocamos em questão a própria existência semiótica da leitura, ao enfatizar a necessidade de apreender como o sentido advém aos sujeitos que lêem. Se ler é fazer abstrações, tal existência pressupõe uma competência leitora e intérprete para que o leitor possa "fazer ser" o sentido, idéia essa apoiada na (des) e (re)construção do que está construído. $\mathrm{O}$ ato de leitura pressupõe então a concepção de operação e geratividade que se relaciona sempre com o contato singular entre texto e leitor, sujeito este guiado por arranjos e procedimentos pertencentes ao próprio texto.

\footnotetext{
Por particulares e diversos que sejam, os textos ativam elementos comuns - o que é pressuposto de qualquer teoria sobre o sentido, da mesma maneira, postula-se a descrição do próprio evento de leitura com o estabelecimento de suas possíveis regularidades, a identificação do mesmo no diferente, no ato particular. É o que pretende a semiótica, que aqui exploramos, com a consideração do perceptivo e do emocional. Por mais difusas que sejam as percepções, por mais vasto que seja e complexo que seja o universo das emoções humanas, elas são passíveis de descrição (MARCHEZAN, 2004, p. 146).
}

Tomando, pois, as palavras da autora citada, pensamos que semiotizar o ato de leitura é justamente procurar observar no diferente, isto é, em cada ato de leitura possível e particular, regularidades que nos conduzam à sistematização de um fazer que não é e não pode ser aleatório. Essa regularidade pode ser encontrada quando trabalhamos com um conjunto de textos considerados como uma totalidade. Estabelece-se, então, um modo de compreender o processo de leitura, ou seja, de entender, pela relação texto-matriz e texto-interpretativo, por exemplo, o que ocorre no processo de ler. Tal relação permite reconstruir por meio de um processo analítico, o movimento de leitura, entendido por nós comouma performance realizada pelo leitor.

Estudar uma performance de leitura é então observar uma recuperação por abstração do simulacro de produção do sentido. Da livre intervenção interpretativa do leitor chegamos a uma interpretação regulada por características textuais que já prefiguram movimentos interpretativos. Dessa maneira, compreender a leitura por meio de textos interpretativos é buscar nos enunciados mecanismos enunciativos que participaram da interpretação, ao averiguar no produto traços da 
produção. Assim, podemos dar conta da geração e dos processos de reconhecimento dos enunciados pelas especificidades de um fazer performativo como a leitura. Atentamos ainda para o fato de que a ação de ler se vê envolvida por restrições que determinam a realização do discurso interpretante: limites de ordem sociocultural, impostos pelo hábito, pelas ritualizações, pelos esquemas e pelos gêneros.

De qualquer maneira, tal performance pressupõe uma competência do leitor, comparável, ainda que não necessariamente idêntica, à do produtor do texto. Nesse momento, entender cada um dos termos do binômio (competência/performance) vai permitir delinear considerações acerca da estrutura do ato de ler.

A análise dos discursos narrativos faz com que nos deparemos, a todo instante, nas suas dimensões pragmática e cognitiva, com sujeitos performantes (quer dizer, realizando seqüências de comportamentos programados) que, para agir, precisam possuir ou adquirir antes a competência necessária: o percurso narrativo do sujeito se constitui desse modo de dois sintagmas que têm os nomes de competência e performance. (GREIMAS e COURTÉS, [1983], p. 63).

A leitura é aqui considerada como uma seqüência de comportamento programado e, por isso, analisada nas bases dos domínios de competência e performance. É, então, por meio da análise de textos interpretativos, a partir de uma leitura feita, que procuramos dar conta operatoriamente de uma realidade empírica como a leitura. Ainda com Greimas e Courtès ([1983], p. 328) “a performance identifica-se numa primeira abordagem, com o ato humano, que interpretamos (em português comum) como um 'fazer ser' e a que damos a formulação canônica de uma estrutura modal, constituída por um enunciado de fazer que rege um enunciado de estado". A performance estando ligada, pois, ao conceito de "transformação" que produz um novo estado de coisas, está "condicionada, isto é, sobremodalizada", pelo tipo de competência de que se acha dotado o sujeito performador, em nosso caso, o sujeito leitor. Observar a leitura como uma performance, isto é, uma execução na dimensão pragmática, indica uma tentativa de descrição e de compreensão da leitura como uma atividade humana particular.

Em relação à performance que é um fazer, a competência em semiótica relaciona-se a um saber e/ou poder fazer. Considerando essas duas modalidades constituintes da competência de um leitor, notamos, em princípio, que o poder é também passível de ser articulado a uma 
capacidade leitora. Se resgatarmos articulações modais, observamos, por exemplo, que um sujeito que não pode ler está no âmbito da impotência (não poder fazer), pois lhe falta a competência necessária para o fazer.

A modalidade do saber, por sua vez, configurada enquanto ato em potência é separável do fazer sobre o qual incide. Nesse sentido, de acordo com Greimas e Courtès ([1983], p. 62), "se o ato é um fazer-ser, a competência é aquilo que faz ser, todas as preliminares e pressupostos que tornam a ação possível”. Encarando o leitor, então, como um sujeito que deve possuir determinadas competências para poder ler, podemos dizer que "qualquer seqüência de comportamento pressupõe, por um lado, um programa narrativo virtual e, por outro, uma competência particular que torna possível sua execução"(GREIMAS e COURTÉS, [1983], p. 63).

Esse “comportamento" explicitado pelos autores é aproximado por nós ao comportamento de leitura e, portanto, requer uma "competência particular". O leitor-receptor vai ser descrito, então, como um sujeito dotado de uma competência e "apreendido em um momento de seu devir, em uma ótica mais dinâmica, em um ponto de vista mais humanizante adotado pela semiótica" (GREIMAS e COURTÉS, [1983], p. 372). Podemos distinguir, assim, uma competência sêmio-narrativa, de que se encarrega a enunciação, e uma competência discursiva e textual, que definem a própria enunciação como uma instância de mediação que possibilita a performance.

No âmbito geral de uma "teoria da competência", destacamos a importância do estudo da modalidade do saber para a performance de leitura. Torna-se fundamental observar que o saber do leitor está ligado "à produção, à circulação do saber, de sua presença e de sua ausência (o não-saber) e, mesmo, de seus graus” (GREIMAS e COURTÉS, [1983], p. 388). Enfatizamos a noção de "presença ou ausência e dos graus de saber" que estão envolvidos no ato de ler e que irão influenciar a leitura de um texto e o entendimento de sua significação mediante a captação de suas estruturas de significação. Dessa forma, ficam envolvidas no instante de leitura as variações dessa modalidade do saber do leitor. Cremos que, dependendo da variação desse saber, determinadas posições diante do ato de ler serão acionadas. Fontanille $(1987$, p. 31) em relação ao saber vai dizer:

On sait que la langue, en termes de savoir, est constituée comme une mémoire sociale qui rassemble une connaissance idéale, ou optimale des structures et des mécanismes préssuposés par la parole. Si on peut généraliser cette observation au 
discours, on se rappellera alors que ce qui joue, en sémiotique, le role de la "langue saussurienne", ce sont les structures sémio-narratives".

Dessa maneira, todo e qualquer produtor/leitor possuiria esse saber (estruturas sêmionarrativas) que fariam o papel de um conhecimento ideal de produção e reconhecimento da discursivização. A partir de um determinado tipo de saber e suas variações, podemos supor, então, que um sujeito cognitivo tenha acesso, seja às organizações mais figurativas, seja às organizações mais abstratas.

Ainda, em relação ao saber que entra na constituição da competência do leitor, pensamos que as afirmações feitas por Fontanille (1987, p. 49) ajudam a entender o motivo pelo qual ofazer-receptivo de um leitor se processa de determinada maneira:

En effet, si le sujet 'informé' dispose d'un savoir niveau 'n', le sujet 'cultivé' peut être doté soit d'un hyper-savoir de niveau ' $n+1$ ', soit d'un hyper-savoir d'un niveau ' $n-1$ '; dans le premier cas, la culture est un mode d'organisation discursive et figurative de l'information: c'est une modalité 'contensive'; dans le second cas, la culture est une mise en relation des savoirs informatifs avec des couches sémantiques plus profondes, par exemple avec l'idéologie ou les axiologies propres à un groupe. Si on considère en revanche le sujet de faire cognitif, l'hyper-savoir apparaîtra comme la competénce cognitive nécessaire à la réalisation du programme cognitif: il pourra être glosé, selon les cas, comme savoir observer, savoir interpréter, savoir chercher, etc $^{2}$.

Fiorin em As Astúcias da Enunciação (1996) discorre sobre as competências que o enunciador necessita para discursivizar seu texto. Cremos, então, que, como o processo de leitura está atrelado ao de produção do sentido, tais competências sobre as quais fala o autor podem muito

1 Sabe-se que a língua, em termos de saber, é constituída como uma memória social que se assemelha a um conhecimento ideal, ou optimal das estruturas e dos mecanismos pressupostos pela parole. Se se pode generalizar essa observação ao discurso, lembrar-se-á então que o que desempenha o papel, em semiótica, da "língua saussureana", são as estruturas sêmio-narrativas (Tradução nossa).

2 De fato, se o sujeito 'informado' dispõe de um saber de nível ' $\mathrm{n}$ ', o sujeito 'culto' pode ser dotado seja de um hiper-saber de nível ' $n+1$ ', seja de um hiper-saber de um nível ' $n$ - 1'; no primeiro caso, a cultura é um modo de organização discursiva e figurativa da informação: ela é uma modalidade çontensiva'; no segundo caso, a cultura coloca em relação saberes informativos com camadas semânticas mais profundas, por exemplo, com a ideologia ou as axiologias próprias a um grupo. Se se considera, por outro lado, o sujeito do fazer cognitivo, o hiper-saber aparecerá como a competência cognitiva necessária à realização do programa cognitivo: ele poderá ser glosado, de acordo com o caso, como saber observar, saber interpretar, saber buscar, etc (Tradução nossa). 
bem servir para os propósitos de uma performance de leitura, já que, tanto para produzir como para receber um texto, elas devem existir. Podemos, dessa forma, correlacionar as competências que Fiorin (1996) atribui para o enunciador e inseri-las, também, no universo de saberes do leitor Invertemos, portanto, o eixo, redirecionando tais competências para o receptor/leitor:

a) competência lingüística: o leitor deve possuir uma competência básica para poder reconhecer a gramática (sistemas morfológico, fonológico, sintático) e o léxico de uma língua;

b) competência discursiva: esta engloba uma competência narrativa; o leitor deve saber reconhecer transformações de estado presentes em todos os textos e seu arranjo em frases de um esquema canônico que parece ser universal; uma competência discursiva propriamente dita, que concerne de um lado à tematização e à figurativização e, de outro, ao espaço, ao tempo e ao ator. Além disso, o leitor deve ser capaz de reconhecer mecanismos argumentativos, implícitos no uso da norma lingüística, das figuras de pensamento aos modos de citação, do discurso alheio, aos efeitos de objetividade e de realidade, subjetividade etc;

c) competência textual: o leitor deve saber identificar o uso da semiótica objeto que foi veiculado no discurso (processos de criação de imagens no cinema e na televisão e os processos de textualização em língua natural);

d) competência interdiscursiva: relaciona-se a um saber cultural e ideológico do leitor, ou seja, a competência enciclopédica;

e) competência intertextual: permite ao leitor observar as relações contratuais ou polêmicas que um texto mantém com os outros;

f) competência pragmática: corresponde ao reconhecimento dos valores ilocutórios dos enunciados por parte do leitor;

g) competência situacional: o leitor deve ser capaz de compreender a situação em que se dá a comunicação.

A ativação de todas as competências arroladas acima permite-nos caracterizar um "leitor ideal", ou seja, aquele que sabe e pode reconhecer no momento da leitura todas as instâncias produtoras de um texto. Dessa maneira, para a realização do fazer (ler), levamos em conta, neste trabalho, a posição do sujeito leitor modalizado pelo saber, no desenvolvimento do processo de leitura, uma vez que essa competência é requerida para uma capacidade de percorrer os níveis de significação, selecionando os componentes no conjunto do percurso gerativo do sentido. Fazemos menção particularmente ao item (b) descrito acima no que diz respeito à competência discursiva do leitor. 
É nesse "percurso" de identificação dos elementos discursivos constitutivos de um texto que o sujeito leitor deve preencher "lacunas" do texto-fonte orientado por um sistema de atração que regula os mecanismos de construção do sentido. Esse sistema se apóia na recorrência de pontos de estímulo do texto-base, norteadores da interpretação. Durante a leitura, entra em ação a capacidade do leitor em reconhecer as estruturas produtoras do texto-fonte e, conseqüentemente, em “estabelecer a relevância de certos componentes e não de outros para a significação do texto em questão" (ORLANDI, 1996b, p. 198).

Os componentes do texto-fonte, tal como são descritos por meio do percurso gerativo do sentido, provocam determinadas reações e guiam a leitura. Acreditamos, nós, analistas, que, com o instrumental do percurso gerativo do sentido, pode ser observado como e por que leitores se apropriam de determinados temas e figuras do discurso. Como temas e figuras se articulam a todos os níveis de geração do sentido, esses níveis estarão implicados para que se descreva o ato de recepção, a leitura.

\subsection{Figuratividade e leitura}

Denis Bertrand (2003, p. 154) afirma que, ao ler um texto literário, entramos imediatamente nos domínios da figuratividade. Isso nos conduz a pensar que a primeira via de acesso ao texto se dá por meio do universo construído pelas figuras do discurso, pois como diz Fiorin (2002, p. 65) "a figura é todo conteúdo de qualquer língua natural ou de qualquer sistema de representação que tem um correspondente perceptível no mundo natural". Dessa forma, o ato de recepção é regrado, em um primeiro momento, pela maneira de recuperar e reconstruir as instâncias figurativas do texto de leitura.

Procuramos estabelecer, portanto, as relações entre o componente figurativo e as possíveis aberturas interpretativas do ato de ler. Nessa direção, visamos a examinar a constituição figurativa dos textos interpretativos via resgate da figuratividade do texto-fonte para leitura. Essa recuperação possibilita analisar comparativamente duas totalidades textuais e, por conseguinte, duas formas de privilegiar isotopias do discurso.

Seria pertinente lembrar que a ação de ler e, por conseguinte, de privilegiar isotopias é regulada pela competência do leitor. Assim, se a leitura for considerada fácil, para um conjunto de leitores, em particular, determinadas isotopias podem ser selecionadas. Ao contrário, se o leitor se depara com um texto com o qual sua competência leitora é incompatível, a seleção de elementos 
durante a leitura será regulada por uma escolha mais lenta de figuras mais esparsas. Isso quer dizer que o leitor irá percorrer o texto e reconhecer nele apenas elementos perceptíveis do mundo natural sem que um fio de permanência seja estabelecido e possibilite a constituição de um universo figurativo. Nesse caso, estamos nos referindo somente aos elementos mais concretos do discurso (figuras) que, revestem, por sua vez, isotopias mais abstratas.

A própria noção de leitura aí também se erige, na medida em que, estando atrelada à figuratividade, permite inclusive pensar na complexificação dos atos de ler ao longo do aprendizado da leitura. Um leitor mais "despreparado" pode permanecer apenas no nível figurativo, ao passo que um leitor mais "avisado" busca logo um significado mais amplo para o texto a partir dos elementos figurativos. Tudo isso depende do encadeamento figurativo identificado pelo leitor no momento da leitura, pois conforme Fiorin (1995, p. 80) "a depreensão dos temas subjacentes a um texto figurativo só é possível a partir do confronto cuidadoso das figuras que se articulam e se encadeiam no interior dele, formando uma rede". O leitor incapaz de reconhecer o enlace figurativo do texto não é competente para perceber a rede coerente formada pelas figuras. Além do mais, após o reconhecimento das figuras e a depreensão dos temas do texto, o leitor deve possuir a capacidade ainda de "enquadrar todos os temas disseminados ao longo do texto e englobá-los dentro de um tema mais geral que sintetize de maneira ampla todo o conjunto" (FIORIN, 1995, p. 87).

Seguimos a proposição de isotopia tal qual é definida por Bertrand (2003, p. 420-421) quando explicita que esse conceito se refere à "recorrência de um elemento semântico no desenvolvimento sintagmático de um enunciado, que produz um efeito de continuidade e permanência de um efeito de sentido ao longo da cadeia do discurso". O conceito de isotopia nos remete à susceptibilidade de um texto apresentar várias leituras possíveis, isto é "leituras múltiplas" ou "leitura plural”. Nesse sentido, Greimas e Courtés ([1983], p. 252) afirmam que

\footnotetext{
A impressão da 'abertura' infinita do texto é freqüentemente causada por leituras parciais: esta ou aquela seqüência do discurso, tomada separadamente, pode conter, com efeito, um grande número de isotopias que ficam contudo suspensas devido à sua incompatibilidade com as seqüências que seguem e que tem por função, entre outras, desambigüizar a seqüência poliisotópica, deixando subsisitir para o conjunto do texto apenas um número restrito de leituras possíveis.
}

Dessa forma, como um texto pode conter diversas isotopias, principalmente os literários, vários percursos de leitura propostos estão a disposição do leitor que vai tomar como caminho esta 
ou aquela isotopia. Isso nos possibilita averiguar, pelos diferentes níveis isotópicos, se no ato de leitura o leitor apenas reconhece superficialmente, isotopias figurativas - "que concernem antes de mais nada aos atores, ao espaço e ao tempo no desenvolvimento da narrativa, por exemplo" (BERTRAND, 2003, p. 188), ou se os leitores chegaram a isotopias temáticas que subjazem às figuras instaladas no discurso.

Os leitores, desse modo, ao entrar em contato com o texto literário perseguem e elegem um fio condutor guiado pelas isotopias. Sendo assim, "a leitura consistirá muitas vezes em hierarquizá-las e reconhecer, isolando-a, uma isotopia regente mais profunda, que dominará e controlará os conjuntos de isotopias de nível superior" (BERTRAND, 2003, p. 189). A escolha, no momento da leitura, desta ou daquela isotopia é estratégica, uma vez que ela é responsável pela interpretação. Se pensarmos no leitor inscrito no texto, essa escolha estará em acordo com o páthos previsto no texto literário, pois o enunciador já seleciona, para o enunciatário, percursos figurativos de leitura que conduzem a um percurso temático, mais abstrato. $\mathrm{O}$ enunciatário considerado coenunciador já recebe, dessa maneira, o trajeto figurativo a ser seguido no ato de ler, uma vez que, em harmonia com o enunciador, ambos devem compartilhar do mesmo universo figurativo para a manutenção da harmonia entre éthos e páthos.

O sujeito, por meio de um fazer seletivo, escolhe, no universo isotópico do texto a direção de leitura, para a qual irá traçar seu caminho na superfície textual. Esse fazer seletivo é regido, como diz Bertrand (2003, p. 189), por "um saber" que se relaciona a "diferentes decisões de leitura”, já que cada leitor escolhe e valoriza determinadas isotopias a seu modo. Nesse sentido, em uma das etapas do movimento de leitura, o sujeito formularia hipóteses por meio de uma superposição de isotopias, isto é, levando em conta sua organização em regentes e regidas no texto. "A leitura consiste em antecipar-lhes a existência e em atualizar nos encadeamentos e elipses do texto, os elementos sêmicos que serão compatíveis com ela”. (BERTRAND, 2003, p. 190) A leitura ocorre, portanto, de contínuas negociações com o sentido, advindas das suposições, o que podemos caracterizar como um dos princípios da interação entre texto e leitor. Nessa direção, a leitura em semiótica, unida à capacidade de fazer abstrações, em um primeiro momento, cuidaria da valorização de isotopias “capazes de reger em 'profundidade' as significações de superfície" (BERTRAND, 2003, p. 189).

Greimas (1973, p. 66) considera ainda que, dependendo do conhecimento sociocultural do leitor, uma ou outra isotopia será estabelecida e nós acrescentamos: privilegiada como a regente ou secundarizada como a regida. Dessa forma, cumpre examinar, pela relação texto-matriz e textos interpretativos, o processo que permite o estabelecimento de isotopias regentes e regidas durante uma performance de leitura. Podemos averiguar, assim, como possíveis isotopias regentes no texto- 
fonte não se constituem enquanto tal em uma produção interpretativa. Não devemos nos esquecer de que o nível discursivo é um nível superior de enriquecimento dos níveis fundamental e narrativo. Portanto, ao seguir um percurso por meio da figuratividade de um texto, o leitor está ao mesmo tempo percorrendo uma narratividade e valores euforizados edisforizados no nível fundamental.

Ainda com Greimas, podemos afirmar que dentro da heterogeneidade do discurso há variações e dimensões da isotopia que dependem do contexto no qual esse mesmo discurso está inserido. Alguns fatores são responsáveis por essa heterogeneidade: uma grade cultural seria uma condição de estabelecimento desta ou daquela isotopia por um determinado leitor

A leitura é descrita, então, como um reconhecimento e uma fixação a partir da percepção do leitor, dependendo de uma competência em questão. Esse reconhecimento recobre, portanto, as variações organizadas em torno do mais concreto ao mais abstrato. Isso nos encaminha aos terrenos da percepção da iconicidade, da tematização e das manifestações graduais da figuratividade de acordo com o uso que o discurso faz dela e dos efeitos das construções discursivas.

Nesse movimento de leitura, entra em jogo o reconhecimento do leitor em relação a um efeito de referenciação forte ou, inversamente, de uma abstração formada pela baixa densidade sêmica. A interação leitor e espaço figurativo nos orienta a ver no ato de leitura a criação de um "mundo" pautado por um efeito de realidade e sensibilização. Ao ler o texto, sob uma axiologia sociocultural fixadora de normas de leitura, delineia-se um espaço de atração - leitor $\leftrightarrow$ figuras e figuras $\leftrightarrow$ leitor - no qual vemos ser erigido o próprio sentido em devir na figuratividade. Falamos, nesse caso, do "sujeito individual e sua própria competência perceptiva" unida a uma instância de "sensibilização, pois o afeto é indissociável da percepção em si mesma” (BERTRAND, 2003, p. 248). Importante notar que esses dados propiciam afirmar que as recorrências do olhar receptivo dos leitores configuram, no ato de expressar o fazer interpretativo, em um texto interpretativo, um éthos depreendido pelas contingências da performance de leitura.

\subsection{O texto interpretativo escolar}

Esperava-se que, após uma trajetória de estudo de textos orientada por práticas pedagógicas vigentes nas escolas brasileiras, os alunos tivessem desenvolvido certas competências e habilidades para leitura e interpretação textual. Logo, um aluno em seu último ano de Ensino Médio, por meio dessa competência-leitora e intérprete supostamente adquirida ao longo do percurso escolar, deveria saber ler e interpretar os mais diversos tipos de textos. Teríamos, então, um poder e 
um saber interpretar um texto-fonte como competência pressuposta do sujeito operador, o sujeito da ação do ato de ler e depois o sujeito do ato de escrever sobre o que entendeu da leitura feita.

No entanto, segundo Fiorin (1997), o desempenho observado na prática de interpretação de textos demonstra que o ensino de leitura e interpretação, tal qual vem sendo praticado na maioria das escolas, parece não ter ainda assimilado os avanços feitos pelas teorias lingüísticas.

A aula de interpretação consiste em responder a um questionário com perguntas que não representam nenhum desafio intelectual ao aluno e que não contribuem para o entendimento global do texto. Muitas vezes o professor não se satisfaz com os textos e os roteiros de interpretação dos livros didáticos, seleciona algum texto e faz uma bela interpretação em classe. Se um aluno lhe pergunta como enxergar numa produção discursiva as coisas geniais que ele nela percebeu, costuma apresentar duas respostas: para analisar um texto é preciso ter sensibilidade; para descobrir os sentidos dos textos, é necessário lê-lo uma, duas, três, $n$ vezes. (FIORIN, 2002, p. 9).

Se, para a leitura e a interpretação textual, Fiorin (2002) nos apresenta o simulacro de um contexto escolar, para as práticas de produção de texto escrito, é Geraldi (2001, p. 39, grifo nosso) quem nos encaminha a perceber que:

Há uma incapacidade generalizada de articular um juízo e estruturar lingüisticamente uma sentença. E, para comprovar tais afirmações, os exemplos são abundantes: as redações de vestibulandos, o vocabulário da gíria jovem, o baixo nível de leitura comprovável facilmente pelas baixas tiragens de nossos jornais, revistas, obras de ficção, etc.

Esse diagnóstico atestado pelo autor reflete as condições de produção dos textos escritos por alunos em situação de ensino-aprendizagem Da mesma maneira, podemos dizer que os produtores de textos interpretativos escritos apresentam uma "falta de domínio das organizações

3 O destaque dado ao termo é para demonstrar uma prática de leitura e interpretação de textos que ocorre, de uma maneira geral. Assim, nosso corpus, apesar de ser em número limitado, toma, na verdade, toda a dimensão de uma prática que ocorre na escola. 
discursivas, do desconhecimento da gramática narrativa e da discursiva e, também das condições sócio-históricas específicas de produção e de recepção textual" (BARROS, 1985, p. 256). A relação leitura e produção escrita se faz aqui necessária, na medida em que o aluno-leitor materializa sua interpretação por meio de um texto escrito e é pelas marcas deixadas no enunciado que podemos reconstituir o ato enunciativo de leitura. Dessa forma, o ato de ler estará implicado na descrição dos mecanismos de construção do sentido das produções escolares, analisadas como enunciados que têm pressuposto um enunciador que constrói seu texto determinado por uma cena enunciativa escolar.

O contexto escolar nos direciona a perceber que, embora haja teorias que se ocupam do tratamento da interpretação de textos na escola e de documentos oficiais ${ }^{4}$ que subsidiam a prática pedagógica dos professores, não há historicamente uma aplicação pedagógica sistematizada para esse ensino, demonstrando haver um abismo entre a teoria e a prática, no que se refere ao ensino formalizado de leitura.

Essa falta de sistematização firmou-se como um modo de ensinar a interpretação de texto na escola, sobressaindo a prática subjetiva do professor em detrimento da incorporação de alguma teoria que subsidiasse a própria prática docente. Sob esse ponto de vista, Almeida Filho (1993, p. 11) afirma que "o conjunto de forças das tradições de ensinar, social e institucionalmente marcadas, se integram de alguma forma com as contribuições pessoais [da abordagem] do professor". Essa "tradição de ensinar" nas escolas, segundo Almeida Filho (1993), exerce influências variáveis sobre o professor e cria uma ideologia de ensino de produção de textos interpretativos na escola, ideologia essa que produz no professor a ilusão de que sua prática de ensino, no que se refere à leitura e interpretação de textos, cumpre o papel educacional pretendido.

Embora este trabalho esteja pautado em uma pesquisa sobre leitura na escola, não a abordaremos do ponto de vista da prática pedagógica, buscando encontrar razões para a problemática da crise da leitura. Tampouco, tentaremos elencar formas de ensinar ou aprender a ler baseadas em práticas didáticas variadas. Esta pesquisa justifica-se por propiciar reflexões teóricas que explicitem o papel do sujeito leitor e intérprete pela análise do que se lê e como se lê. Entretanto, as práticas de ensino de leitura e interpretação nos auxiliam na construção de nosso corpus de análise, na medida em que os textos interpretativos escritos são ancorados por um gênero do domínio discursivo escolar, modelado pelas coerções que a instituição "Escola" impõe.

Diante desse panorama escolar apresentado, a partir do corpus selecionado para esta pesquisa, examinaremos pelo menos algumas das condições de produção dos textos interpretativos escolares, em um movimento que parte da interioridade dos textos para o entendimento da relação

4 Documentos oficiais compreendem as propostas curriculares de Língua Portuguesa e os subsídios às propostas curriculares de Língua Portuguesa. Estes são constituídos por coletânea de textos, publicados por autores que teorizam sobre o ensino-aprendizagem da língua materna, tanto para a leitura como para a escrita. 
com a exterioridade sócio-histórica que os constitui. Dizemos "exterioridade sócio-histórica", na medida em que "crenças fincadas na sociedade e representativas de diferentes segmentos sociais ditam o que deve ser dito. Depois, porque coerções de gênero ditam como dizer" (DISCINI, 2005a, p. 34).

Dessa forma, a maneira, como o sujeito-leitor e intérprete responde a determinadas coerções, permite depreender um modo recorrente de dizer vinculado a um gênero discursivo específico, pois como atesta Maingueneau (1997, p. 35) "há gênero a partir do momento que vários textos se submetem a um conjunto de coerções comuns". Nesse sentido, pela totalidade de textos, nos será dado a conhecer o conjunto de coerções próprias a práticas escolares na configuração de um texto da esfera de circulação institucional. Assim, somos capazes de delimitar um modo de ler e interpretar particular articulado a um ritual enunciativo escolar.

A cada gênero associam-se momentos e lugares de enunciação específicos e um ritual apropriado. O gênero como toda instituição, constrói o tempo-espaço de sua legitimação. Estas não são "circunstâncias" exteriores, mas os pressupostos que o tornam possível (MAINGUENEAU, 1997, p. 36).

Das questões de gênero, especificamente, devemos enfatizar as noções de estilo que nos possibilitam chegar ao éthos do leitor escolar. Conforme Bakhtin (2003, p. 261), o estilo é determinado "pelas escolhas lexicais, fraseológicas e gramaticais da língua. Ainda, segundo o mesmo autor, "o estilo está indissoluvelmente ligado ao enunciado e a formas típicas de enunciados" (BAKHTIN, 2003, p. 265). Em outros termos, “o estilo é o conjunto de marcas lingüísticas exigidas por um gênero" (FIORIN, 2004b, p. 102). Na verdade, essas marcas constroem-se pela maneira de "operar do enunciador no momento da produção do discurso" (GREIMAS e COURTÉS, [1983], p.350), isto é, pelas escolhas feitas no ato de discursivizar. A ênfase é dada na construção de um estilo "individual" e a recorrência desse estilo na produção discursiva constitui uma totalidade.

Em nosso caso, a totalidade é formada pela reunião de textos interpretativos, de onde buscaremos a imagem de um sujeito, construída por essa totalidade. Tal imagem erigida a partir de uma unidade de sentido depreende-se dos textos pelo modo de dizer e pela maneira de "valorizar valores”. Entramos aqui em uma outra noção de estilo. Discini (2003, p. 36) assim define estilo: 
Partimos, então, da noção de que estilo é um efeito de sentido e, portanto, uma construção do discurso. Acreditamos que esse efeito emerge de uma norma, determinada por recorrências de procedimentos na construção do sentido, desde os níveis mais profundos até os mais superficiais do percurso gerativo do sentido.

A totalidade de textos escritos remete, a partir de um único fato de estilo, à configuração de um gênero porque as escolhas de um indivíduo se repetem na de seus congêneres. Conforme Discini (2003, p. 35), "às estruturas recorrentes de um conjunto de discursos, subjaz, portanto, uma estrutura única e abrangente". Nessa esteira, ainda segundo Discini (2003, p. 35) "o feixe de regularidades subjacente a uma totalidade" de discurso, caracterizada também por uma temática e uma estrutura composicional, faz emergir o estilo de um gênero.

O gênero, enquanto virtualidade, possibilita realizações estilísticas recorrentes observadas na materialização dos textos. "As recorrências referidas, constituindo uma regularidade e uma previsibilidade de um modo de dizer, remetem, por sua vez, a uma unidade virtual, que aguarda realização em situações de comunicação, numa circularidade de sentido" (DISCINI, 2003, p.35). As maneiras recorrentes de organizar os enunciados nos textos reportam, portanto, à constituição de um sistema, que, por sua vez, pressupõe regularidades. Assim, podemos dizer que elas constituem uma homogeneidade ${ }^{5}$ regida por regras, a qual prevê "recorrências de procedimento na construção de sentido da totalidade" (DISCINI, 2003, p. 61).

Em contrapartida à regularidade do fato de estilo que corresponde à dos mecanismos de construção do sentido nos três níveis de produção textual, conferindo homogeneidade a uma totalidade discursiva, é também inerente, à constituição, à presença de irregularidades, que lhe proporcionam um caráter heterogêneo, condição para as marcas de subjetividade dos textos. Nessa perspectiva, "a totalidade de estilo é homogênea e heterogênea. $\mathrm{O}$ fato de estilo garante essa homogeneidade, já que pressupõe uma semelhança de procedimentos na construção do sentido que, por sua vez, constrói o efeito de individuação de uma totalidade" (DISCINI, 2003, p. 67). Se estilo é um modo recorrente de dizer e esse modo assume valores ideológicos disseminados pelas condições de produção, que, por sua vez, vão estabelecer as bases de coerção para esse modo de dizer, o estilo (as escolhas realizadas) é revestido por valores ideológicos advindos das condições de produção, determinando traços da própria subjetividade.

Particularmente, nosso olhar analítico busca nos textos escolares a recorrência do que é dito por meio do exame da constância de uma estrutura. O sujeito é, então, reconstruído a partir de

A homogeneidade, nesse contexto, é entendida como o conjunto de características estilísticas comuns apresentadas pelos sujeitos. 
estratégias discursivas que ele emprega na discursivização e textualização de sua interpretação do texto-fonte. Discini (2003, p. 18), a respeito disso, atesta que

deve haver uma recorrência no modo de ver, sentir, captar, reconstruir, enfim, a 'realidade', no que diz respeito a uma enunciação que forja um éthos, um estilo. Deve haver uma coerência interna num conjunto de discursos, uma permanência de modos, objetos e meios, estes, que constituem critérios distintivos da própria mímese aristotélica, proposta na Arte Poética. Deve haver um crer e um fazer crer que fundam uma previsibilidade reconhecível.

No caso específico das produções interpretativas escritas da totalidade escolar, podemos dizer que as condições de ensino propiciam a existência de determinadas recorrências encontradas na totalidade examinada, pelo próprio saberdisponibilizado pela Escola.

$\mathrm{O}$ estilo dos textos interpretativos baseia-se, dessa maneira, numa coerência interna no conjunto que tais textos constituem. Pelo percurso gerativo do sentido podemos depreender o estilo dos textos dos alunos a partir de uma previsibilidade que emerge da totalidade, previsibilidade compreendida como "um estoque que potencializa" o sujeito leitor para um modo próprio de usar tal repertório. Cumpre averiguar, então, o estoque que os alunos-intérpretes possuem e, mais ainda, o modo como manejam tal estoque, uma vez que o aluno detém um modo específico de usar o repertório adquirido ao longo do percurso escolare da vida.

Até o momento, explanamos sobre as relações entre o texto interpretativo e o ambiente escolar, na tentativa de vincular as coerções de gênero, próprias à escola, com os textos produzidos pelos sujeitos alunos. Pensamos, dessa maneira, como as projeções feitas por umgênero, vinculadas à situação de comunicação escolar, fazem com que o aluno leitor utilize determinadas coerções como instrumento para "a construção de lugares enunciativos" (DISCINI, 2003, p. 53) por meio de suas produções interpretativas.

A interpretação deve ser pensada, então, como a "instância resultante da leitura, na medida em que o sujeito que lê, reflete, no texto de leitura, determinadas expectativas, o que irá direcionar sua busca" (CORTINA, 2004, p. 154). Dessa forma, o ato de interpretar tem sempre de ser considerado como uma relação, isto é, devemos necessariamente colocar em cotejo duas totalidades textuais (texto-fonte e texto-interpretativo) para que sejam percebidas as "filtragens"

Termo empregado por Maingueneau em Gênese dos discursos, 2005a, p.158. 
operadas pelo sujeito-leitor a partir do texto-matriz para leitura. Tais filtragens remetem a convergências ou divergências de composição (acréscimos ou reduções na construção do texto do leitor), enfim, identidades e alteridades que alicerçam a interpretação. Ainda, a práxis interpretativa deve ser considerada como "rearranjo", na medida em que o sujeito no ato de recepção reorganiza as estruturas do Percurso Gerativo do Sentido.

Isso nos leva a tentar entender como a interioridade - as estruturas dos textos interpretativos - é concebida em função de uma exterioridade a si e interioridade do outro - as estruturas do texto literário. A produção interpretativa é sustentada, então, no texto que lhe deu origem, já que ler é produzir um texto que tem como referente um outro texto. A interioridade do discurso do aluno deve ser concebida, então, pela sua relação com a interioridade do texto-fonte, que não deixa de ser o "outro" recuperado pela leitura.

Elaboramos, portanto, as características de um texto interpretativo padrão ${ }^{7}$ com base na proposta de Fiorin $(2005$, p. 106) quando se refere à dissertação. A partir desses critérios chegamos a algumas coerções do texto interpretativo:

a) deve ser temático, pois não se destina a contar episódios singulares ou a descrever seres concretos e particulares, mas dá explicações, faz análises e avaliações válidas para muitos casos concretos e particulares; por isso, constrói-se dominantemente com termos abstratos;

b) a ordenação não é temporal como na narrativa, em que se relata um acontecimento depois do outro, de acordo com sua progressão no tempo, mas é uma ordenação construída com base em relações lógicas: pertinência, causalidade, coexistência, implicação, correspondência, etc;

c) como esse tipo de texto pretende expor verdades gerais (ou pelo menos tomadas como tal), válidas para muitos casos particulares, o tempo é o presente atemporal; podem-se, eventualmente usar outros tempos, principalmente, outros dois tempos do sistema do presente: o pretérito perfeito e o futuro do presente;

d) normalmente a estrutura composicional desse tipo de texto é: introdução, desenvolvimento e conclusão;

e) normalmente, o enunciador não se projeta no interior do enunciado: daí a preferência por não usar a primeira pessoa do singular, mas a primeira pessoa do plural ou as formas impessoais;

f) predominância de dois microtipos textuais: o opinativo e o expositivo;

Dizemos "padrão" para nos referir a um tipo de produção aceita institucionalmente. 
g) dependência do texto-fonte para leitura e interpretação;

h) aparato teórico-metodológico para análise, isto é, desbastamento do plano da expressão por meio da observação realizada no plano do conteúdo, onde predominam interpretações sobre o mundo.

Dessa forma, o texto interpretativo destina-se ao comentário, crítica, princípios de análise, buscando explicar a interioridade de um outro texto. Em termos da semiótica greimasiana, o produtor desse gênero deve apresentar um domínio das organizações sêmio-narrativas e discursivas, além do trabalho formal com a expressão escrita que oambiente escolar exige.

Reconstruiremos, portanto, por meio de um exame da recorrência do fazer desses alunos, uma imagem de leitor e intérprete escolar, erigida da totalidade coletada para análise, pelo modo de estruturar o conteúdo dos textos. É, a partir desse modo próprio de construção textual, que depreendemos um corpo, um caráter e um tom de voz que se articulam às coerções de gênero. Surge um estilo e, por conseguinte, um éthos, pois como declara Discini (2003, p. 57) “estilo é éthos, é modo de dizer".

Orientados então por escolhas enunciativas que partem desde a imanência discursiva até a aparência textual, os enunciadores dos textos interpretativos engendram a escolha tímica fundamental (euforizações e disforizações), escolhas axiológicas que fundamentam a construção ideológica do discurso até elementos da expressão que participam da textualização. Reforçamos, ainda, que todas as escolhas que participam das produções escolares se dão fundamentalmente em relação ao texto-fonte para leitura.

Dessa maneira, as noções aqui apresentadas de leitura e texto interpretativo atreladas à teoria semiótica conduzirão ao desenvolvimento das análises das duas totalidades textuais propostas para esta dissertação. Como teoria da significação, a semiótica deve explicitar, sob forma de uma construção conceitual, as condições da apreensão e produção do sentido e com isso permitir-nos distinguir os níveis de descrição dos textos considerados como resultados de um dispositivo estruturado de regras e de relações. O movimento analítico empreendido neste trabalho observa, em última instância, por meio do instrumental teórico-metodológico da semiótica um éthos da totalidade escolar responsivo, que dialoga com a imagem do leitor - páthos inscrito no texto literário. 


\section{CAPÍTULO II - Análise semiótica do conto $O$ presente dos magos de $\mathbf{O}$. Henry}

\subsection{Conto: $O$ presente dos magos $^{8}$}

Apresentamos o texto-fonte da atividade de expressão escrita desenvolvida com os alunos da $3^{\text {a }}$. Série do Ensino Médio. Lembramos que passagens de outros contos do mesmo autor, em momento oportuno, serão cotejadas com este, para que possamos averiguar recorrências necessárias para a depreensão da imagem do enunciador e do enunciatário em O. Henry. Antes, porém, de apresentar o conto propriamente dito, gostaríamos de expor algumas notas sobre a vida e a obra do autor em questão.

O. Henry, pseudônimo do escritor norte-americano William Sydney Porter, nasceu em Greensboro na Carolina do Norte em 1862. Desenvolveu atividades de vários tipos e fundou em 1882 o jornal humorístico The Rolling Stones. Envolvido em um escândalo no banco onde trabalhava, fugiu para Honduras e México com o fora-da-lei Al Jennings. Voltou ao país, foi preso e durante os três anos que passou na prisão começou a escrever contos, publicados inicialmente em jornais e mais tarde reunidos em volumes.

As publicações de O. Henry são impulsionadas pela verdadeira sede por ficção que apareceu nos Estados Unidos no fim do século XIX, época em que se via a grande difusão dos romances em série e das short stories (contos). Nessa época, revistas que publicavam qualquer coisa que fosse sucinta (novelas, crônicas, contos) eram lançadas freqüentemente e inundavam o país de lado a lado.

Durante essa década de popularidade do conto é que O. Henry desenvolve sua técnica e escreve centenas deles, pois dependia inteiramente do que escrevesse para sobreviver. Pressionado por editores, que sempre exigiam novas histórias para atender a demanda do público, O. Henry escrevia um conto por semana, contando ao final de sua carreira com mais de trezentos. Inspirou-se principalmente na massa humana que se aglomerava nas ruas de Nova Iorque, em geral nos bairros pobres.

Lançou coletâneas de contos como a de 1904, intitulada Cabbages and Kings (Repolhos e Reis), que reúne histórias de aventura e de revolução em um país fictício da América Central e The

8 As passagens recuperadas do conto, para fins de análise, estarão em itálico e entre aspas no corpo do texto. 
Four Million (Os Quatro Milhões) de 1906 em que O. Henry apresenta seus melhores contos, abusando de uma técnica que causou sensação na época: o conto de twist ou final inesperado. Foram lançados, ainda, Heart of he West (Coração do Oeste) em 1907 e The Voice of the City (A Voz da Cidade) em 1908, tendo uma aceitação ainda mais entusiasmada por parte do público e permitido a O. Henry consolidar definitivamente sua popularidade.

Por fim, apareceram em 1909 Options (Opções) e Roads of Destiny (Caminhos do Destino), e em 1910 Strictly Business (Estritamente Negócios) e Whirligigs (Carrosséis). Estes dois foram os últimos a serem publicados ainda em vida pelo escritor (três mais seriam publicados postumamente), que morreu em Nova Iorque em 1910. Suas últimas palavras foram: "Levantem o estore para que eu possa ver Nova Iorque. Não quero ir para casa no escuro".

\section{$\underline{\text { O presente dos magos - O. Henry }}$}

Um dólar e oitenta e sete centavos. Era tudo. E sessenta centavos eram em moedas. Moedas economizadas uma a uma, pechinchando com o dono do armazém, o dono da quitanda, o açougueiro, até o rosto arder à muda acusação de parcimônia que tais pechinchas implicavam. Três vezes Della contou o dinheiro. Um dólar e oitenta e sete centavos. E no dia seguinte seria Natal.

Não havia evidentemente mais nada a fazer senão atirar-se ao pequeno sofá puído e chorar. Foi o que Della fez. O que leva à reflexão moral de que a vida é feita de soluços, fungadelas e sorrisos, com predomínio das fungadelas.

Enquanto a dona da casa gradualmente passa do primeiro ao segundo estágio, vamos dar uma espiada na casa. Um apartamento mobiliado, a oito dólares por semana. Não era exatamente miserável, mas tinha essa palavra pronta para o grupo de mendicância.

No vestíbulo embaixo havia uma caixa de correspondência na qual carta nenhuma seria posta, e um botão de campainha que nenhum dedo mortal jamais apertaria. Encontrava-se ali também um cartão anunciando o nome de "Mr. James Dillingham Young".

O "Dillingham" fora acrescentado durante um anterior período de prosperidade, quando seu possuidor estava ganhando trinta dólares por semana. Agora, que a receita baixara para vinte dólares, as letras de "Dillingham" pareciam nubladas, como se estivessem pensando seriamente em abreviar para um modesto e despretensioso D. Mas sempre que Mr. James Dillingham Young voltava para casa e chegava ao seu apartamento lá em cima, era chamado de "Jim" e carinhosamente abraçado por Mrs. James Dillingham Young, já apresentada ao leitor como Della. O que está muito bem.

Della terminou de chorar e cuidou do rosto com a esponja de pó. Postou-se junto à janela e ficou a contemplar melancolicamente um gato cinzento caminhando sobre uma cerca cinzenta num quintal 
cinzento. Amanhã seria Dia de Natal e ela tinha apenas um dólar e oitenta e sete centavos para comprar o presente de Jim. Estivera a economizar tostão por tostão havia meses, e esse era o resultado. Vinte dólares por semana não dão para nada. As despesas tinham sido maiores do que calculara. Sempre são. Apenas um dólar e oitenta e sete centavos para comprar o presente de Jim. O seu Jim. Muitas horas felizes passara ela planejando comprar-lhe alguma coisa bonita. Alguma coisa fina, rara, legítima - algo que estivesse bem perto de merecer a honra de ser possuída por Jim.

Havia um espelho de tremó entre as janelas da sala. Talvez o leitor já tenha visto um espelho de tremó num apartamento de oito dólares. Uma pessoa muito esguia e muito ágil pode, com observar seu reflexo numa rápida seqüência de tiras longitudinais, obter uma concepção bastante acurada de sua aparência. Della, por ser esguia, lograra aperfeiçoar-se nessa arte.

Subitamente, afastou-se da janela e postou-se diante do espelho. Seus olhos estavam brilhantes, mas sua face perdeu a cor ao cabo de vinte segundos. Num gesto rápido, soltou o cabelo e deixou desdobrar-se em toda a sua extensão.

Ora, os James Dillingham Youngs tinham dois haveres de que muito se orgulhavam. Um era o relógio de ouro de Jim, que pertencera a seu pai e a seu avô. O outro era o cabelo de Della. Morara a Rainha de Sabá no apartamento do outro lado do poço de ventilação, e Della teria algum dia deixado o seu cabelo cair fora da janela para secá-lo e depreciar assim as jóias e as riquezas de Sua Majestade. Fora o Rei Salomão o zelador, com todos os seus tesouros empilhados no porão, e Jim teria puxado o relógio cada vez que por ele passasse, só para vê-lo arrancar as barbas de inveja.

O cabelo de Della, pois, caiu-lhe pelas costas, ondulando e brilhando como uma cascata de águas castanhas. Chegava-lhe abaixo do joelho e quase lhe servia de manto. Ela então o prendeu de novo, célere e nervosamente. A certo momento, deteve-se e permaneceu imóvel, enquanto uma ou duas lágrimas caíam sobre o puído tapete vermelho.

Vestiu o velho casaco marrom; pôs o velho chapéu marrom. Com um ruge-ruge de saias e coma centelha brilhante ainda nos olhos, correu para a porta e desceu rapidamente a escada que levava à rua.

Parou onde havia um letreiro anunciando: "Mme Sofronie, Artigos de Toda Espécie para Cabelos". Della subiu a correr um lance de escada e se deteve no alto, arquejante, para recompor-se. Madame, corpulenta, alva demais, fria, dificilmente faria jus ao nome de "Sofronie".

- Quer comprar meu cabelo? - perguntou Della.

- Eu compro cabelo - disse Madame. - Tire o chapéu e vamos dar uma olhada no seu.

Despenhou-se, ondulante, a cascata de águas castanhas.

- Vinte dólares - ofereceu Madame, erguendo a massa com mão prática.

- Dê-me o dinheiro depressa - pediu Della.

Oh, as duas horas seguintes voaram com asas róseas. Perdoe-se a metáfora gasta. Della se pôs a vasculhar as lojas à procura de um presente para Jim. 
Encontrou-o por fim. Fora certamente feito para ele e para ninguém mais. Nada havia que se lhe parecesse nas outras lojas, e ela as revirara de alto a baixo. Era uma corrente de platina, curta, simples e de modelo discreto, proclamando adequadamente seu valor por sua mesma substância e não por qualquer ornamentação espúria - como o devem fazer todas as coisas boas. Era digna até do Relógio. Tão logo a viu, soube que tinha de ser de Jim. Era como ele. Serenidade e valor - a descrição se aplicava a ambos. Vinte e um dólares cobraram-lhe por ela, e Della correu para casa com os oitenta e sete centavos. Com aquela corrente no relógio, Jim poderia preocupar-se decentemente com o tempo na frente de qualquer pessoa. Grande como era o relógio, ele às vezes o consultava meio envergonhado devido à velha tira de couro que usava em lugar de corrente.

Quando Della chegou a casa, seu embevecimento cedeu lugar a um pouco de prudência e razão. Pegou os ferros de frisar, acendeu o gás e pôs-se a reparar os estragos causados pela generosidade acrescida ao amor. O que sempre é uma tarefa muito árdua, queridos amigos - uma tarefa gigantesca.

Ao cabo de quarenta minutos, sua cabeça estava coberta de pequenos caracóis cerrados, que a faziam parecer, admiravelmente, um menino vadio. Contemplou sua imagem no espelho durante longo tempo, crítica e cuidadosamente.

- Se Jim não me matar - disse consigo mesma - antes de olhar-me pela segunda vez, dirá que pareço uma corista de Coney Island. Mas que podia eu fazer... oh, que podia eu fazer com um dólar e oitenta e sete centavos? Às sete horas, o café estava preparado e uma frigideira quente no fogão esperava o momento de fritar as costeletas.

Jim nunca se atrasava. Della dobrou a corrente no côncavo da mão e sentou-se a um canto da mesa, perto da porta pela qual ele sempre entrava. Ouviu então seus passos no primeiro lance da escada e empalideceu por um instante. Ela tinha o hábito de rezar pequenas preces silenciosas a propósito das mínimas coisas diárias, e agora murmurava:

- Oh, Deus, fazei-o por favor achar-me ainda bonita!

A porta se abriu, Jim entrou e a fechou. Parecia magro e muito sério. Pobre sujeito, apenas vinte e dois anos e já responsável por uma família! Precisava de um sobretudo novo e não tinha luvas.

Jim avançou alguns passos, tão rígido quanto um perdigueiro na pista de uma codorniz. Seus olhos estavam fitos em Dela e havia neles uma expressão que ela não conseguia ler e que a aterrorizava. Não era raiva, nem surpresa, nem desaprovação, nem horror; não era nenhum dos sentimentos para os quais ela estava preparada. Ele simplesmente a fitava com aquela peculiar expressão na face.

Della esgueirou-se para fora da mesa e se encaminhou para ele.

- Jim, querido - gritou -, não me olhe desse jeito! Mandei cortar o cabelo e o vendi porque não poderia passar o Natal sem dar um presente a você. Ele crescerá de novo... não se aborreça, por favor. $\mathrm{Eu}$ tinha de fazer isso. Meu cabelo cresce terrivelmente depressa. Diga "Feliz Natal!", Jim, e fiquemos felizes. Você não sabe que coisa bonita, que belo presente tenho para você.

- Mandou cortar o cabelo? - perguntou Jim a custo, como se não se tivesse ainda compenetrado desse fato patente após o mais árduo esforço mental. 
- Cortei-o e vendi-o - disse Della. - Você não continua a gostar de mim do mesmo jeito, então? Estou sem cabelo, não estou?

Jim olhou à volta do aposento de modo curioso.

- Você diz que seu cabelo se foi? - insistiu, com um ar de quase idiotia.

- Não precisa procurar por ele - disse Della. - Foi vendido, como lhe disse... vendido, não está mais aqui. É Véspera de Natal, querido. Seja bonzinho comigo, fiz isso por sua causa. Talvez fosse possível contar os cabelos da minha cabeça - continuou ela, com súbita e grave doçura -, mas ninguém poderá jamais avaliar o meu amor por você. Posso fritar as costeletas, Jim?

Emergindo do seu transe, Jim pareceu despertar rapidamente. Abraçou a sua Della. Por dez segundos, contemplemos, com discreta atenção, qualquer objeto inconseqüente, noutra direção. Oito dólares por semana ou um milhão por ano - qual a diferença? Um matemático ou uma pessoa arguta daria a resposta errônea. Os magos trouxeram presentes valiosos, mas isso não estava entre eles. Esta asserção obscura será esclarecida mais tarde.

Jim tirou um pacote do bolso do sobretudo e atirou-o sobre a mesa.

- Não me interprete mal, Della - disse. - Não acho que haja alguma coisa, corte de cabelo, raspagem ou xampu, capaz de fazer-me gostar menos da minha mulherinha. Mas se você abrir esse pacote, poderá ver por que fiquei abafado no princípio.

Alvos dedos ligeiros desfizeram o atilho e o embrulho. Ouviu-se então um grito estático de alegria, e depois, ai!, uma súbita mudança feminina para as lágrimas e os gemidos, que exigiram o imediato emprego de todos os poderes de consolação do senhor do apartamento.

Pois sobre a mesa jaziam Os Pentes - o jogo de pentes para cabelos que Della adorara havia muito numa vitrine da Broadway. Belos pentes, de tartaruga legítima, orlados de pedraria - da cor exata para combinar com o lindo cabelo desvanecido. Eram pentes caros, ela o sabia, e seu coração se limitara a desejá-los e a suspirar por eles sem a menor esperança de vir um dia a possuí-los. E agora pertenciam-lhe, mas as tranças que os anelados enfeites deveriam adornar não mais existiam.

Ela, porém, os apertou contra o peito e, por fim, pôde erguer os olhos nublados, sorrir e dizer:

- Meu cabelo cresce tão depressa, Jim!

E então Della pulou como um gatinho chamuscado e gritou:

$-\mathrm{Oh}$ ! oh!

Jim ainda não vira o seu belo presente. Ela lho estendeu ansiosamente na palma da mão aberta. O fosco metal precioso parecia brilhar com o reflexo do seu jubiloso e ardente espírito.

- Não é uma beleza, Jim? Vasculhei a cidade toda para achá-lo. Doravante, você terá de ver as horas uma centena de vezes por dia. Dê-me o seu relógio. Quero ver como fica nele.

Em lugar de obedecer, Jim deixou-se cair no sofá, pôs as mãos atrás da cabeça, e sorriu:

- Della - disse -, vamos pôr os nossos presentes de Natal de lado e deixá-los por algum tempo. São lindos demais para poderem ser usados agora. Vendi o relógio para conseguir o dinheiro com que comprei os seus pentes. Que tal se você fritasse as costeletas agora? 
Os magos, como sabem, eram homens sábios - homens maravilhosamente sábios - que trouxeram presentes para a Criança na manjedoura. Inventaram a arte de dar presentes natalinos. Sendo eles sábios, seus presentes eram sem dúvida igualmente sábios. Possivelmente admitiam o privilégio de troca em caso de duplicação. E aqui lhes contei canhestramente a desimportante crônica de duas crianças tolas, num apartamento, as quais da maneira a mais insensata, sacrificaram, uma pela outra, os maiores tesouros de seu lar. Mas como derradeira palavra para os sensatos dos dias que correm, seja dito que, de todos que dão presentes, os dois foram os mais sábios. Todos que dêem e recebam presentes como os deles são os mais sábios. Em toda parte, os mais sábios. São os magos.

O. HENRY (1988). O presente dos magos. In: O. HENRY. Caminhos do destino e outros contos. Trad. Alzira Machado Kawall e José Paulo Paes. São Paulo: Ediouro, p. 34 - 38.

\subsection{Análise semiótica do conto $O$ presente dos magos de $O$. Henry}

A análise do conto torna-se importante neste trabalho, para que possamos averiguar as relações estabelecidas entre as estruturas de $O$ presente dos magos com as dos textos da esfera de comunicação escolar, em nosso caso as produções interpretativas dos alunos. Devemos lembrar ainda que, para chegar ao éthos do leitor escolar como produtor de textos interpretativos, aqui cremos ser importante a depreensão do éthos do enunciador e do páthos do enunciatário inscritos nos contos literários de $\mathrm{O}$. Henry. Apesar de os alunos terem se deparado no momento da leitura com uma imagem de narrador e narratário, pois em um texto particular é da imagem desses actantes da enunciação enunciada de que tratamos, afirmamos que, essas imagens construídas, tendo em vista apenas esse segundo nível da hierarquia enunciativa, remetem ao éthos e ao páthos circunscritos à totalidade.

Dessa forma, é possível observar, em uma instância interpretativa específica, as relações que os sujeitos intérpretes entretêm com o éthos do enunciador e com o páthos do enunciatário, erigidos a partir do narrador e narratário de um texto literário, na discursivização de uma interpretação escrita e, conseqüentemente, na construção de sua própria imagem como leitor. Ao ler um texto como uma unidade, o leitor entraria em contato, então, com imagens de narrador e narratário, como já dissemos. Entretanto, se podemos recuperar o todo na parte, isto nos permite afirmar que éthos e páthos também se encontram como elemento constitutivo do unus, ou seja, de 
um único texto. Todavia, somente pelo exame da totalidade da qual esse texto participa, é que se pode confirmar a hipótese de éthos/páthos feita, isto é, se as imagens do narrador/narratário convergem ou divergem da imagem do enunciador/enunciatário.

Cria-se, dessa maneira, no momento da leitura, um vínculo entre éthos e páthos projetados pelo enunciador, incorporados nos papéis de narrador e narratário do conto, e éthos do leitor intérprete. Nesse sentido, um simulacro de leitor pode ser construído pela aceitação e concordância ou por refutação, discordância e negação das imagens projetadas no texto-fonte para leitura.

\subsubsection{Nível fundamental}

Tendo em vista uma relação categorial básica no nível fundamental do conto $O$ presente dos magos de O. Henry, podemos estabelecer uma primeira oposição mínima de articulação do sentido: gratuidade vs utilitarismo, depreendida a partir dos termos presença vs ausência do nível narativo. A escolha dessa relação se fundamenta, pois, na possibilidade de distinguir dois estados existenciais para os sujeitos da narrativa. Se pensarmos, então, que, o sujeito e o objeto são constituintes básicos do nível narrativo, o quadrado semiótico estabelecido por nós demonstra uma sintaxe fundamental que organiza o conto em função de aquisições e privações, dadas segundo possessões e despossessões. A gratuidade e/ou utilitarismo fundamenta as aquisições e perdas de objetos ao longo do conto.

Pela passagem transcrita, averiguamos como o termo mínimo "ausência" dá movimento à narrativa pela instalação da obrigatoriedade da busca e, conseqüentemente, da passagem para uma conjunção (presença) com um objeto material.

"Um dólar e oitenta e sete centavos. Era tudo. E sessenta centavos eram em moedas. Moedas economizadas uma a uma, pechinchando com o dono do armazém, o dono da quitanda, o açougueiro, até o rosto arder à muda acusação de parcimônia que tais pechinchas implicavam. Três vezes Della contou o dinheiro. Um dólar e oitenta e sete centavos. E no dia seguinte seria Natal. 
Não havia evidentemente mais nada a fazer senão atirar-se ao pequeno sofá puído e chorar. Foi o que Della fez. O que leva à reflexão moral de que a vida é feita de soluços, fungadelas e sorrisos, com predomínio das fungadelas.

Enquanto a dona da casa gradualmente passa do primeiro ao segundo estágio, vamos dar uma espiada na casa. Um apartamento mobiliado, a oito dólares por semana. Não era exatamente miserável, mas tinha essa palavra pronta para o grupo de mendicância.

No vestibulo embaixo havia uma caixa de correspondência na qual carta nenhuma seria posta, e um botão de campainha que nenhum dedo mortal jamais apertaria. Encontrava-se ali também um cartão anunciando o nome de 'Mr. James Dillingham Young,",.

Lembramos que essa organização profunda do texto literário é representativa, no nível narrativo, de conjunções e disjunções em relação aos objetos materiais. Podemos, portanto, examinar a axiologização desses termos como categorias ressemantizadas pela projeção da categoria fórica: euforia vs disforia. A presença/conjunção e a ausência/disjunção se homologam no discurso à isotopia temático-figurativa do mundo material (euforia buscada). A conjunção com o objeto de valor descritivo (presente utilitário) é euforizada; a disjunção com tal objeto de valor é disforizada. Tal axiologização demonstra, portanto, valores considerados atraentes ou repulsivos. Desse ponto de vista, Tatit (2003, p. 199) afirma que "se tomarmos a foria como uma força que transporta as categorias semânticas, torna-se plausível admitir que estas últimas já surgem conformadas por modulações tensivas".

Dessa maneira, de acordo com os termos e suas operações de asserção e negação, a presença diz respeito ao maior relaxamento possível, ao passo que a ausência é o motor gerador de tensões. Durante o desenrolar do conto, a aquisição do "material" e a possibilidade de entrar em conjunção com ele são consideradas como termo eufórico, visto que há uma valorização melhorativa em relação à aquisição de objetos utilitários, passando de descontinuidades a continuidades, isto é, da ausência à presença.

Estabelecemos, assim, o seguinte quadrado semiótico como uma forma sumária da sintaxe do conto descrita emnível profundo:

Utilitarismo

Presença (3)

Conjunção
Gratuidade

Ausência (1)

Disjunção 


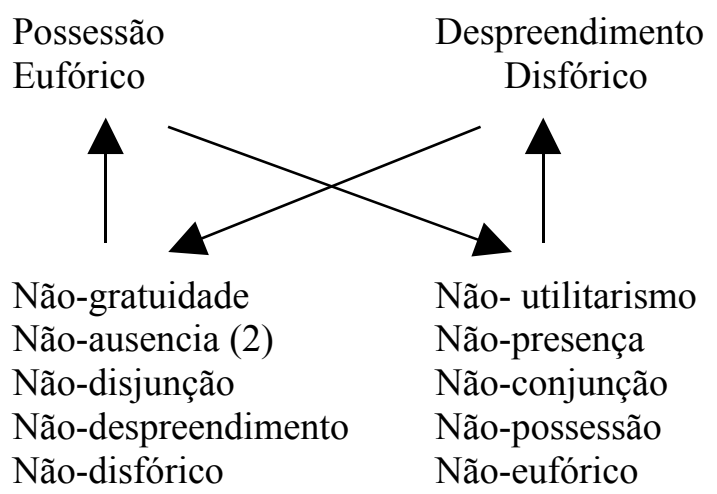

Dessa forma, temos o seguinte movimento: (1) - gratuidade (ausência) $\rightarrow(2)$ - nãogratuidade (não-ausência) $\rightarrow(3)$ - utilitarismo (presença), isto é da disjunção à conjunção com objetos materiais. No início do conto, então, os bens materiais, objeto de valor descritivo, são tidos como termos eufóricos, figurativizados como "pentes" e "corrente de relógio". Mas, à medida que o conto progride até seu final, vemos que há uma inversão no componente tímico. O objeto de valor descritivo, o presente utilitário, perde seu caráter euforizante, pois seus valores são deixados de lado, pelo advento de novos valores não fundados no materialismo, isto é, valores pautados pela gratuidade. Essa constatação, que possibilita afirmar a existência de uma mudança na foria, pode ser verificada pelo excerto a seguir:

“- Della - disse -, vamos pôr os nossos presentes de Natal de lado e deixá-los por algum tempo. Vendi o relógio para conseguir o dinheiro com que comprei os seus pentes. São lindos demais para poderem ser usados agora. Que tal se vocêfritasse as costeletas agora?"

Notamos, dessa maneira, que no texto o desprendimento (abdicação) assume um caráter eufórico, ao passo que a possessão (materialismo) assume um caráter disfórico. Por outro lado, a abdicação desse bem material se dá em função de um sentimento que ultrapassa o utilitarismo, sentimento este guiado pelo "amor'. Nesse sentido, Tatit (2003, p. 199) vai dizer que: 
A euforia opera a passagem das relações tensivas, caracterizadas por rupturas, às relações relaxadas, as que estabelecem os elos contínuos entre os elementos. Contrariamente, a disforia compreende a passagem das continuidades às descontinuidades que geram as tensões.

Pela inversão de valores, constatada no final do conto, seria possível estruturar um segundo quadrado semiótico, tendo por base uma nova projeção da categoria fórica. Nesse quadrado, temos o movimento que parte da presença em direção à ausência: (1) presença $\rightarrow$ (2) nãopresença $\rightarrow$ (3) ausência. Essa mudança na articulação do conto é resultado de uma transformação no componente juntivo, já que a conjunção como objeto material não pôde ser efetivada.

\begin{tabular}{|ll|}
\hline Utilitarismo & Gratuidade \\
Presença (1) & Ausência (3) \\
Conjunção & Disjunçao \\
Possessão & Despreendimento \\
Disfórico & Eufórico \\
\hline Não-gratuidade & Não-utilitarismo \\
Não-ausência & Não-presença (2) \\
Não-disjunção & Não-conjunção \\
Não-despreendimento & Não-possessão \\
Não-eufórico & Não-disfórico \\
\hline
\end{tabular}

O termo disfórico gratuidade (ausência) do primeiro quadrado semiótico, portanto, é aquele que acarreta sofrimento ao actante-ator do enunciado devido à dificuldade em se obter o 
material e, em seguida, no segundo quadrado, por adquirir um saber sobre a impossibilidade de "conjunção efetiva" com os valores investidos nele. Mudam-se os valores, mudam-se os estados de alma, as paixões: o desejo de conjunção com a possessão material seria eufórico, mas resulta em aflição; resignação. Por outro lado, a disjunção com a possessão material gera um estado de desprendimento pela seu caráter de gratuidade.

O conto apresenta, assim, uma evolução bastante peculiar em relação à estruturação do nível fundamental. Até a conjunção com os bens materiais, estipulamos um primeiro quadrado semiótico que afirma euforicamente a presença e, conseqüentemente, a conjunção. Por outro lado, o final do texto nos permite constituir um novo quadrado que disforiza a completude (presença) com bens materiais. Esse é o movimento fundamental do texto de $\mathrm{O}$. Henry: da ausência à presença e da presença à ausência, isto é, do utilitarismo à gratuidade.

Dessa maneira, há, por meio desse jogo de afirmações e negações da categoria mínima, utilitarismo ve gratuidade, uma preferência por afirmar axiologicamente as incompletudes dos sujeitos. Fecha-se o círculo diante da impotência e da ruptura, ironizando e revelando o pavor que se tem dessa mesma incompletude, dada por meio do peso e da preponderância do tema da "falta existencial" que permeia os relacionamentos e que se figurativiza nas situações concretas de troca de presentes materiais desencontrados. Vale lembrar, portanto, que a maneira de apresentar as euforizações e disforizações no nível fundamental já demonstra uma escolha que supõe um modo próprio de presença no mundo do sujeito. (DISCINI, 2005a, p. 35).

\subsubsection{Nível narrativo}

Nesse componente do Percurso Gerativo do Sentido, examinaremos os programas narrativos que englobam a sucessão de estados e transformações surgidos a partir de uma relação entre sujeito e objeto. Dessa forma, as estruturas narrativas permitem observar as possibilidades de tensão no que concerne ao percurso do sujeito e sua relação com o objeto de valor pela distância que os separa.

Resgatando, então, Vladimir Propp (1983) e sua seqüência falta-busca-prova, observamos que o conto apresenta uma "falta inicial" que, na terminologia de Greimas, é denominada como um estado de falta, ou seja, uma disjunção: “Um dólar e oitenta e sete centavos. Era tudo".

A partir desse estado de falta, é que se desenrola a narrativa e todas as ações do conto são organizadas em torno dessa ausência. Esse obstáculo (não ter dinheiro) encontrado pelo sujeito 
Della para a aquisição do objeto-valor visado permite-nos averiguar que há uma tensão crescente ao longo do conto até a conjunção final. Dizemos, ainda, que no início presenciamos um estado de distanciamento máximo entre o sujeito e seu objeto de valor, responsável por um máximo de tensão no universo da narrativa, pois estamos diante de uma disjunção indesejada. Disjunto do objeto-valor e distante dele a tensão aumenta e se intensifica.

Dessa forma, as transformações do sujeito ao longo do conto ocorrerão em função da disjunção sujeito/objeto e do distanciamento entre eles, uma vez que um querer é instaurado, e qualquer que seja o querer há a implicação de um sujeito disjunto de um objeto (um sujeito de falta) que visa à conjunção, à liquidação da falta. O querer, como diz Bertrand (2003, p. 324), “é suficiente para instaurar um sujeito, para estabelecer uma falta, para orientar um perfil de valores". Estabelece-se, então, um programa narrativo de busca por um /querer-estar-conjunto/ com o objeto de valor "presente". Ainda, como afirma Tatit (2001, p. 25) "as disjunções impostas às funções de sujeito e objeto revelam a predominância das descontinuidades tensivas no âmbito narrativo". O conto apresenta, então, uma descontinuidade inicial, que é a matriz de disjunções narrativas entre sujeito e objeto, uma vez que o actante (Della) tenta recobrar a continuidade (conjunção).

Della é considerada, então, como um sujeito de busca, estabelecendo uma direção para liquidar sua falta, vista como carência ou necessidade. Ainda com Bertrand (2003, p. 322), "o sujeito de busca é definido por uma seqüência modal cuja primeira modalidade é o querer", já que o desejo e a necessidade impulsionam a ação. Tal sujeito de busca é definido pela modalidade do quererfazer, isto é, estando disjunto do objeto ( $\mathrm{S} \quad \mathrm{O})$, quer estar conjunto com ele ( $\mathrm{S} \quad \mathrm{O})$. As transformações para a aquisição de objetos-valor são evidenciadas por um sujeito de busca, em que o querer modaliza e domina na construção do simulacro de Della. Dessa forma, se há um querer estar conjunto, Della é sujeito de estado e sua modalidade é o querer-ser. Mas, na verdade, ela é sujeito de estado e de fazer. Por isso, quer ser e quer fazer.

Della quer, dessa maneira, tornar-se competente para suprir a falta ou estado de disjunção inicial. Na relação $S_{1}$ (Della), Ov (dinheiro) e Ov (presente), devemos explicitar que o sujeito não busca o objeto em si, mas o valor investido nesse objeto. A simples existência do desejo implica o valor do objeto visado, e este se confunde com aquele. Dessa maneira, o presente de Jim, mostrado como uma corrente de platina para o relógio, incute o valor de "agradar ao outro", uma vez que esse objeto seria doado a ele.

Neste momento da análise, convém esclarecer teoricamente essa "movimentação" de objetos. Citando Santana (2001, p. 129) “Tanto podemos encontrar objetos que circulam entre sujeitos, como sujeitos e um objeto, como objetos em relação a um sujeito, ou ainda, um objeto disputado por vários sujeitos". Há, portanto, toda uma dinâmica da narrativa que implica em um 
processo de circulação de objetos. O texto apresenta um grupo de objetos visados e valorizados pelos sujeitos do querer: Della e Jim. Como afirma Bertrand (2003, p. 332), "o objeto é compreendido como um simples lugar de fixação e de investimento do valor; e este, produzido pelo uso cultural, está tão estreitamente ligado aos objetos que participa em grande parte de sua definição".

Para entrar em conjunção com o poder-fazer, Della precisa entrar em disjunção com um outro objeto - "seu cabelo". O cabelo de Della é tido como objeto-valor, uma vez que o orgulho, trazido pela beleza deles era o que ela possuía de mais precioso: “Ora, os James Dillingham Youngs tinham dois haveres de que muito se orgulhavam. Um era o relógio de ouro de Jim, que pertencera a seu pai e a seu avô. O outro era o cabelo de Della."

Todo o valor desse objeto está embutido nesse ponto da narrativa: seu cabelo caía "como uma cascata de águas cristalinas", "seus olhos brilhavam", ele trazia-lhe "dignidade pessoal, brio e altivez". Dessa forma, a comparação dada figurativamente no discurso imprime maior valor de desejo ao objeto.

Dada a relação entre sujeitos e objetos dentro do conto, temos, em um primeiro caso, a situação de uma venda/compra de objeto entre Della e Madame Sofronie. Verificamos, então, dois sujeitos e dois objetos envolvidos em uma barganha que para ser efetivada depende da habilidade dos sujeitos em estabelecer uma discussão sobre o valor do objeto em questão: “- Quer comprar meu cabelo? - perguntou Della. - Eu compro cabelo - disse Madame. - Tire o chapéu e vamos dar uma olhada no seu."

Firma-se um contrato fiduciário. Nessa operação de troca entre os sujeitos, o valor proposto aos objetos é reconhecido pelas partes implicadas, assegurando o valor do objeto a ser recebido em contrapartida: "Despenhou-se, ondulante, a cascata de águas castanhas. - Vinte dólares - ofereceu Madame, erguendo a massa com mão prática. - Dê-me o dinheiro depressa pediu Della."

Verificamos, então, que $S_{1}$ entra em conjunção com o objeto (dinheiro) pretendido e, em contrapartida, entra em disjunção com outro objeto-valor (cabelo). Na aquisição do dinheiro dizemos que houve uma aquisição transitiva - atribuição, já que o sujeito do fazer (doador), e o sujeito de estado (beneficiário) são dois atores distintos. Em contrapartida, pode-se dizer que houve uma privação, uma vez que um novo estado de falta foi instituído. Há uma perda de um objeto, uma despossessão, em que o sujeito do fazer é diferente do sujeito de estado. Della conseguiu o dinheiro, entretanto, ficou sem seu cabelo. Em posse do objeto dinheiro, Della consegue comprar o presente a Jim, enfim. 
"Della se pôs a vasculhar as lojas à procura de um presente para Jim. Encontrouo por fim. Fora certamente feito para ele e para ninguém mais. Nada havia que se the parecesse nas outras lojas, e ela as revirara de alto a baixo. Era uma corrente de platina, curta, simples e de modelo discreto, proclamando adequadamente seu valor por sua mesma substância e não por qualquer ornamentação espúria - como o devem fazer todas as coisas boas".

Dessa forma, Della entra em conjunção com um objeto de valor descritivo e a respeito deles, Barros (2001, p. 46) diz que "os valores descritivos, por sua vez, classificam-se em valores objetivos (consumíveis e armazenáveis) e em subjetivos (prazeres, estados de alma)". Isso indica que Della quer entrar em conjunção com um valor que lhe proporcione a "satisfação" de agradar seu marido. Vale lembrar, como também atesta Barros (2001, p. 45), "a escolha de valores corresponde a uma primeira decisão do sujeito da enunciação, quanto ao discurso que será produzido".

Até o momento, analisamos as relações entre Della (actante-sujeito 1), objeto (dinheiro), objeto (cabelos) e objeto (corrente), ou seja, o percurso narrativo de $\mathrm{S}_{1}$. A partir, dos enunciados do fazer podemos, então, vislumbrar o percurso de $\mathrm{S}_{1}$ depois de todas essas considerações sobre a conjunção e disjunção com os objetos.

\section{1) Della não tem dinheiro - vai adquirir dinheiro}

A partir desse estado disjuntivo Della reúne competências para agir, ou seja, o seu fazer transformador. O actante-sujeito possui um querer(fazer) agradar seu marido com "algo que fosse digno da honra de pertencer a Jim" e um dever-fazer já que "no dia seguinte era Natal." Adquire um poder-fazer, pois podia vender seu cabelo e um saber-fazer; adquiriu um saber aonde ir para vendê-lo. Dessa forma, Della torna-se competente e age, vende seu cabelo e obtém o objeto desejado (dinheiro). Institui-se, nesse momento de compra do presente, a realização do sujeito performativo e um relaxamento é demonstrando pela união entreo sujeito e o objeto.

\section{2) Della compra o presente para Jim}

De posse de dinheiro, Della torna-se, mais uma vez, competente para adquirir o objetovalor - "corrente de platina para o relógio". Ela quer e deve presentear o marido, pode, pois adquiriu o dinheiro para tal e sabe onde procurar pelo presente. Della, mais uma vez, por meio de seu fazer transformador, age: "Della vasculhava as lojas à procura do presente de Jim.", 
“Encontrou, por fim. Certamente fora feito para Jim." Apesar das conjunções operadas, uma falta ainda resta. Della ficou sem seu cabelo, "sem seu bem precioso".

A seqüência principal observada é comprar o presente desejado e agradar o marido. Portanto, conseguir o dinheiro é a competência necessária para a compra. Pode-se dizer que há uma "seqüência encaixada", já que para poder comprar o presente é preciso adquirir o dinheiro e, para se obter o dinheiro, é preciso vender os cabelos. Barros (2001, p. 33) diz que no "programa de aquisição reflexiva ou por apropriação (opera-se a conjunção e o sujeito do fazer é igual ao sujeito de estado); de privação transitiva ou por espoliação (opera-se a disjunção e o sujeito do fazer é diferente do sujeito de estado)".

Apesar de menos destacado no texto, já que é o percurso de Della que o texto explicita na grande maioria, a estrutura narrativa do conto apresenta um percurso de estrutura similar para Jim, isto é um percurso emparelhado ao de Della: falta de dinheiro, vender o objeto de maior apreço (relógio), comprar um presente para Della (pentes para cabelo). Jim, em um outro percurso do sujeito performativo, está disjunto do dinheiro. "Vendi o relógio para conseguir dinheiro", o termo "conseguir" demonstra o estado de falta em relação ao objeto visado. Apesar de não estar explícito no texto, houve, por pressuposição, assim como explicitado no percurso de Della, uma barganha, o dinheiro pelo relógio, figurativizada pela "venda". Do mesmo modo, Jim privou-se do objeto que mais se orgulhava - o relógio - cujo valor remete ao apreço familiar: "um era o relógio de ouro de Jim, que tinha sido de seu pai e de seu avô". Compra, então, os pentes para Della com o dinheiro que adquire por meio de tal venda.

No fim do texto, encontramos uma estrutura caracterizada como "troca" de objetos. Della dá a Jim seu presente e Jim, do mesmo modo, presenteia Della com os "pentes". Essa troca, ou dom recíproco, é entendida pela conjunção de $\mathrm{S}_{1}$ com um objeto que ele recebe de $\mathrm{S}_{2} \mathrm{e}$ há, simultaneamente, uma disjunção de outro objeto, atribuído a $S_{2}$. Isso significa uma doação recíproca que constitui uma das formas de transferência ou comunicação de objetos-valor. Nesse sentido, Greimas e Courtés ([1983],p. 67) assinalam que:

As transferências de objetos que se apresentam sob a forma de aquisições e de privações afetam apenas os sujeitos e constituem, na medida em que se revestem de formas canônicas, sistemas de relações inter-humanas, que regulamentam os desejos e os deveres dos homens. 
Ainda, de acordo com os autores ([1983], p. 133) "a doação representa a transformação que dá lugar a uma atribuição e a uma renúncia concomitantes: no plano narrativo, corresponde, portanto, simultaneamente a uma conjunção transitiva e a uma disjunção reflexiva”. Existe, por assim dizer, uma equivalência entre os valores dos dois objetos, pois "a troca é um fazer que situado no interior de uma estrutura binária de sujeitos (numa relação de doação recíproca) constitui uma das formas de comunicação da transferência de objetos-valor" (GREIMAS e COURTÉS, [1983], p. 471). Diante desse fato, observamos dois objetos equivalentes implicados em uma operação recíproca $\mathrm{S}_{1}$ (Della) e $\mathrm{S}_{2}$ (Jim) operam uma performance dupla "subseqüente à conclusão de um contrato". "A troca se realiza, dessa forma, quando há uma crença partilhada pelos parceiros sobre as valências de seus objetos, quando reconhecem juntos sua equi-valência” (BERTRAND, 2003, p. $334)$.

Ao término da troca propriamente dita, o valor proposto aos objetos é reconhecido, "são belos demais", apesar da impossibilidade de gozar do valor investido neles. Notamos, assim, que, ao final da análise do conto, há um engendramento de conjunções e de disjunções que dão suporte à organização do nível narrativo.

\subsubsection{Modalidades e paixões}

No que concerne às modalidades, no início do conto $O$ presente dos magos, o sujeito Della tem uma existência modal definida pelo querer-ser e pelo não-poder-ser, o que torna os objetos buscados por ela desejáveis e impossíveis. Em relação a esse querer Edward Lopes afirma que "o querer é essa vontade e essa emoção que dá partida ao movimento narrativo. Entendendo por movimento a mudança de algo que passa do estado atual de potência, para o estado real, de ato, diremos que o motor do movimento narrativo éa paixão".

Ao longo de seu percurso vemos que a existência modal é alterada por meio das transformações operadas. Na relação de venda do cabelo, Madame Sofronie altera a competência modal de Della no momento em que se estabelece uma relação de barganha. No que diz respeito ao percurso de Della, podemos visualizar o seguinte esquema de modalidades:

-Poder-fazer: possível - pode vender o cabelo;

-Querer-fazer: desejável - quer comprar o presente;

-Não-poder-fazer: impossível - não pode comprar o presente, pois não tem o dinheiro;

-Dever-fazer: indispensável - deve vender o cabelo para conseguir o dinheiro. 
As modalidades encontradas possibilitam, portanto, desenvolver considerações sobre os estados passionais do actante-sujeito Della, uma vez que tomamos como pressupostos teóricos os estados passionais observados a partir de uma concepção de articulação modal sobre a tensividade e a aspectualidade.

Nessa esteira, a intensidade e a extensão do querer, dever, poder e saber são organizadas em um complexo modal tensivo, permitindo que as paixões sejam examinadas pelo viés de correlações tensivas que permitem um efeito de sentido passional pelas combinações de modalidades. O dispositivo, ora esboçado, leva-nos a efeitos de sentidos ditos estados passionais ou estados de alma. Dessa forma, são os fenômenos passionais que regulam a intensidade do discurso (conto), perpassando da sintaxe narrativa à sintaxe tensiva. A tensão é induzida por determinações tensivas impostas ao valor dos objetos, isto é, pela correlação entre intensidade afetiva investida no objeto, por um lado, e sua quantidade ou extensão por outro.

Temos, então, no início do conto, decorrente da falta estabelecida, a iconização da figura do dinheiro, por meio de uma enumeração figurativa:

"Um dólar e oitenta e sete centavos. Era tudo. E sessenta centavos eram em moedas. Moedas economizadas uma a uma, pechinchando com o dono do armazém, o dono da quitanda, o açougueiro, até o rosto arder à muda acusação de parcimônia que tais pechinchas implicavam".

Quanto maior o elenco de figuras, mais a vergonha da pechincha, instalando uma tensão inicial fundada na disjunção e na distância do sujeito e seu objeto visado.

De acordo com Fiorin (1992, p. 57) no caso da vergonha:

Estabelece-se para o sujeito um dever/fazer/ser correlacionado a um não poder/ não fazer/ser. Se o sujeito agir em não conformidade com essa modalidade deôntica receberá, no caso da vergonha, uma sanção cognitiva e negativa, a reprovação própria ou alheia, segundo o destinador da sanção esteja ou não em sincretismo com o sujeito do fazer. Essa reprovação gera a vergonha. 
Della, nesse caso, sabe que não possui a competência para um fazer, ou seja, sabe que não possui dinheiro para adquirir o objeto desejado. Dessa forma, no que concerne às modalidades do querer-ser, o actante-sujeito Della demonstra uma paixão simples. No percurso de Della fica evidente uma maior intensidade do querer, há um desejo excessivo em relação à compra do presente:

"Apenas um dólar e oitenta e sete centavos para comprar o presente de Jim. O seu Jim. Muitas horas felizes passara ela planejando comprar-lhe alguma coisa bonita. Alguma coisa fina, rara, legítima - algo que estivesse bem perto de merecer a honra de ser possuída por Jim".

A esse respeito Barros (1990, p. 61) afirma:

Percebem-se, pelas definições analisadas, mais dois critérios de diferenciação das paixões de objeto: a maior ou menor intensidade do querer - desejo ardente, sôfrego, veemente, excessivo, violento, irreprimível - e os tipos de valores desejados - pragmático-descritível na cobiça, na cupidez na avareza...

A partir desse querer instaura-se um momento de "espera", pois o sujeito desenvolve a expectativa de estar em conjunção com um objeto-valor. Em nosso caso, Della espera entrar em conjunção com o objeto "presente". A partir disso, cria-se um estado de infelicidade e tristeza, pois há a combinação do /querer ser/ com o /saber não poder ser/; um saber sobre as possibilidades de ocorrência da não conjunção desejada pelo sujeito da espera. "Não havia evidentemente mais nada a fazer senão atirar-se ao pequeno sofá puído e chorar. Foi o que Della fez".

Desse estado intenso e não-eufórico de não-conjunção, temos a insegurança de Della de não conseguir o dinheiro, o que vai gerar a aflição decorrente de uma espera tensa. De acordo com Barros (1990, p. 66) "o sentimento de falta resulta do conflito entre /querer ser/ e o /saber poder não ser/ e o /crer ser/ [...] seguidos do sentimento de falta dá lugar a um programa de liquidação da falta". Della tenta suprir a falta de objeto, criando novos percursos passionais. Della pode ser considerada como um sujeito forte e ofensivo, pois um programa de liquidação da falta é gerado 
quando sai para vender seu cabelo e consegue enfim, o dinheiro para adquirir o objeto de valor visado.

De um estado de disjunção e tensão, Della passa a um estado de conjunção e relaxamento. Instaura-se a paixão da satisfação e alegria. Por outro lado, para entrar em conjunção com o objeto-valor visado, Della teve que entrar em disjunção com um outro objeto-valor (cabelo). Temos nesse caso, uma paixão do querer-não-ser que gera o desprendimento e a generosidade, uma generosidade fundada na disposição para dar mais do que se espera, ao pressupor desinteresse pessoal e desapego.

A figura do "soluço" antecipa cataforicamente no discurso a grande perda que ocorrerá ao longo da narrativa. A figura das "fungadelas", por sua vez, antecipa cataforicamente o soluço recolhido, o pranto atenuado, o que remete à evolução da angústia pela perda de um objeto de valor desejável. Temos uma catáfora discursiva. As fungadelas ironizam, portanto, a própria dor humana. Essa dor, por mais contundente que seja, quando os atores se vêem privados cada qual de um objeto de valor descritivo, como a corrente para o relógio e a pentes para os cabelos, decresce. Assim, a figurativização do primeiro parágrafo sintetiza poeticamente o que será narrado ao longo do texto.

\subsubsection{Nível discursivo}

Nesse componente do Percurso Gerativo do sentido, procuramos analisar as estruturas discursivas consideradas como o lugar de desvendamento da enunciação. O nível discursivo é o patamar mais superficial da geração do sentido, o mais próximo da manifestação textual. As estruturas narrativas convertem-se em estruturas discursivas quando assumidas pelo sujeito da enunciação. Tal sujeito opera uma série de escolhas de pessoas, espaços e tempos, temas e figuras para, então, projetá-las nos textos/discursos.

\subsubsection{A espacialização}

Para a análise da categoria espacial do conto, necessitamos antes de tudo distinguir dois modos possíveis de conceituá-la. Dessa maneira, somos levados a observar uma organização da espacialidade tendo em vista um espaço lingüístico e um espaço tópico. No espaço lingüístico 
estamos diante de um espaço constituído tendo como referência os actantes da enunciação em relação aos do enunciado. Não se estabelece, portanto, um espaço geométrico. O espaço tópico, por sua vez, permite observar corpos dispostos em relação a um ponto de referência, instituindo uma direcionalidade aos movimentos emuma determinada dimensão espacial.

Observamos, entretanto, a singularidade do espaço lingüístico por ordenar-se em função do discurso. Tal ordenação faz-se a partir do hic, ou seja, do lugar do ego e é expressa "pelos demonstrativos e por certos advérbios de lugar. O espaço lingüístico não é o espaço físico, analisado a partir das categorias geométricas, mas é aquele onde se desenrola a cena enunciativa" (FIORIN, 2003, p. 174). Por sua vez, em oposição ao aqui está o alhures, que estabelece o espaço do enunciado, ou seja, um ponto marcado no texto. $\mathrm{O}$ espaço tópico, no entanto, pode ser descrito nos moldes de uma programação espacial desenvolvida pela semiótica para averiguar "os procedimentos de programação espacial que permite a realização de uma disposição linear dos espaços parciais, conforme a programação temporal dos programas narrativos" (GREIMAS e COURTÉS, [1983], p. 155).

Se quisermos, entretanto, estabelecer um tipo de "dependência" entre as duas concepções de espaço, temos que observar que o espaço tópico será sempre um especificador do espaço lingüístico, explicitamente manifestado ou não. A esse respeito, Greimas e Courtés afirmam que "o alhures e o aqui discursivos, considerados como posições espaciais zero, são, então, pontos de partida para a instalação da categoria topológica tridimensional que depreende os eixos da horizontalidade, da verticalidade e da prospectividade (adiante/atrás)" ([1983], p. 264-265). Assim, os procedimentos de debreagem e embreagem são compreendidos como mecanismos que aplicam no discurso uma organização espacial que "serve de quadro para a inscrição dos programas narrativos e de seus encadeamentos" (GREIMAS e COURTÉS, [1983], p. 155). Ainda, Greimas e Courtés (1986, p. 208) atestam que:

Il semble difficile, tant du point de vue de l'arbitraire que de celui de l'adéquation, de "contenir" la spacialization au seul niveau discursif. Les structures profondes sont difficilement pensables sans une spacialité shématique: espacements de la sémantique fondamentale, déplacements et parcours de la syntaxe fontamentale. Les structures narratives de surface, en raison des rapports de conjonction et de disjonction qui les soumettent, requièrent, non la spacialité, mais une spacialité9.

Parece difícil, tanto do ponto de vista do arbitrário quanto do da adequação, "conter" a espacialização somente no nível discursivo. As estruturas profundas são dificilmente pensadas sem uma espacialidade esquemática: 
Buscamos, então, uma descrição da espacialidade “concebida como uma distribuição topológica, conforme à definição da própria narrativa e paralela ao seu desenrolar" (GREIMAS, 1993, p. 92). Devemos ser orientados pelo eixo da prospectividade, que corresponde no discurso narrativo, à linearidade do texto seguida pelo percurso do sujeito. Procuramos, dessa maneira, explorar o eixo da prospectividade, a fim de detectar uma distribuição espacial linear, homologável aos percursos narrativos dos sujeitos e à circulação dos objetos-valor. "Essa distribuição espacial não articula senão e unicamente o espaço enuncivo (alhures)" (GREIMAS e COURTÉS, [1983], p. 265). Por meio de uma debreagem espacial enunciva, temos, então, em $O$ presente dos magos, a ancoragem espacial determinada pela instalação do alhures figurativizado pelo topônimo "apartamento/casa" que designa um dos lugares colocados pela narração para ser o sustentáculo dos PNs dos sujeitos. Um alhures que se constrói em função de um espaço fora da cena enunciativa e que se firma como um longe urbano. Essa constatação nos leva a fundar uma análise que dê conta da organização figurativa responsável pelo revestimento de uma estrutura mais abstrata da espacialidade do conto.

O "apartamento", tido como o centro espacial, erige um eixo de localização pela estabilização de um espaço sistêmico que organiza as performances a serem desenroladas ao longo dos programas narrativos. A partir desse locus central, podemos ainda estabelecer um outro ponto de referência mencionado no texto em questão: a figura da "rua" - "correu para a porta e desceu rapidamente a escada que levava à rua". Chegamos a uma segmentação do conto em três seqüências espaciais, levando-se em conta esses dois marcos inscritos no texto:

1. movimentação dos atores pelo espaço do apartamento;

2. movimentação dos atores pelo espaço da rua;

3. movimentação dos atores pelo espaço do apartamento.

Isso posto, somos capazes de observar uma estruturação espacial que articula as categorias da interioridade (apartamento) vs exterioridade (rua). Além disso, articulamos os termos euforia vs disforia - com tais categorias, visto que a adjetivação permite investir categorias axiológicas nos termos da interioridade e da exterioridade. Dessa forma, podemos pensar na aspectualização do espaço descrito pelos modos de passagem de um lugar a outro. Della, ao sair de seu lar, estabelece uma incoatividade do percurso da distância que separa o local do apartamento do lugar visado (rua); a chegada a esse lugar estabelece uma terminatividade. $\mathrm{O}$ trajeto estabelecido

espaçamentos da semântica fundamental. As estruturas narrativas de superfície, em razão de relações de conjnçaão e de disjunção que as submetem, requerem não $a$ espacialidade, mas uma espacialidade (Tradução nossa). 
pela incoatividade, de saída do apartamento, parece acelerar a movimentação pelo espaço em direção à exterioridade, ao passo que o deslocamento produzido na interioridade parece aproximarse mais da estaticidade, descrita pela própria presença desaceleradano espaço dos atores do conto.

Seguindo o recorte dado ao texto, na primeira seqüência, vemos que uma valoração dota o termo da interioridade (apartamento) de uma determinação espacial disfórica, isto é, de uma definição axiológica disforizada em que a ausência e, por conseguinte, a disjunção deixam-se apreender. Assim, a topicalização do alhures pela figura do "apartamento" é construída a partir de uma estrutura de qualificação na qual se encontra a conotação disfórica, sendo iconizado pelas seguintes figuras: "pequeno sofá puído", "um apartamento mobiliado, a oito dólares por semana. Não era exatamente miserável, mas tinha essa palavra pronta para o grupo de mendicância”, "no vestíbulo embaixo havia uma caixa de correspondência na qual carta nenhuma seria posta”, "botão de companhia que nenhum dedo mortal jamais apertaria", "puído tapete vermelho" e "espelho de tremo num apartamento de oito dólares".

A descrição do apartamento pelo processo de iconização dispõe e ordena objetos fazendo emergir um "cenário discursivo" por meio do qual se apreende a isotopia figurativa espacial do mundo circundante dos atores do enunciado, o que não deixa de revelar sobre o próprio sujeito que o habita. Como dizem Greimas e Courtés (1986, p. 208),

Notons qu'un lieu est susceptible d'un investissement sémantique qui est l'équivalent $\mathrm{du}$ rôle thématique pour un acteur; un lieu peut valoriser ou dévaloriser l'acteur qui s'y trouve, et le déplacement peut modifier la competénce modale d'un sujet, de sorte qu'un lieu peut aussi occuper un rôle actanciel ${ }^{10}$.

Por seu turno, na segunda seqüência, o espaço da exterioridade (rua) ganha uma determinação eufórica, pois é o lugar da aquisição da competência necessária (poder) para a conjunção com o objeto-valor (corrente para o relógio e pentes para o cabelo). Na terceira seqüência, de volta ao apartamento, apesar da conjunção com os objetos, ainda resta a sensação de ausência e de disjunção pela não atualização do valor dos objetos no momento da troca dos presentes. Poderíamos dizer, então, que o termo disfórico predomina na categoria topológica da

10 Notemos que um lugar é suscetível de um investimento semântico que é o equivalente do papel temátco para um ator; um lugar pode valorizar ou desvalorizar o ator que aí se encontra, e o deslocamento pode modificar a competencia modal de um sujeito, de modo que um lugar pode também ocupar um papel actancial (Tradução nossa). 
interioridade dando suporte para os temas da incompletude e da despossessão. Ademais, o espaço da rua é o local de aquisição de objetos-valor, ao passo que o espaço da casa é o de ausência de objetosvalor, ou no limite, o da impossibilidade de conjunção total e da atualização dos valores dos objetos. Para corroborar com nossas afirmações, apoiamo-nos em Greimas e Courtés (1986, p. 208) quando dizem que

la division de l'espace en deux lieux distincts est souvent figure par la présence d'un obstacle aux regards (linhe d'horizon, mur) qui délimite une opposition entre le dedans et le dehors; cette opposition, à son tour, génère une division des objets et des sujets en présents et absents [...] l'objet peut être tout près, sous la main, ou plus loin, visible, mais inaccessible sans déplacement ${ }^{11}$.

Devemos verificar assim que o lugar exterior modaliza o sujeito Della para o programa narrativo de aquisição, como comprovado pela seguinte passagem do conto:

"Vestiu o velho casaco marrom; pôs o velho chapéu marrom. Com um ruge-ruge de saias e coma centelha brilhante ainda nos olhos, correu para a porta e desceu rapidamente a escada que levava à rua.

Parou onde havia um letreiro anunciando: "Mme Sofronie, Artigos de Toda Espécie para Cabelos". Della subiu a correr um lance de escada e se deteve no alto, arquejante, para recompor-se. Madame, corpulenta, alva demais, fria, dificilmente faria jus ao nome de "Sofronie".

- Quer comprar meu cabelo? - perguntou Della.

- Eu compro cabelo - disse Madame. - Tire o chapéu e vamos dar uma olhada no seu.

Despenhou-se, ondulante, a cascata de águas castanhas.

- Vinte dólares - ofereceu Madame, erguendo a massa com mão prática.

- Dê-me o dinheiro depressa - pediu Della.

Oh, as duas horas seguintes voaram com asas róseas. Perdoe-se a metáfora gasta. Della se pôs a vasculhar as lojas à procura de um presente para Jim.

Encontrou-o por fim. Fora certamente feito para ele e para ninguém mais. Nada havia que se lhe parecesse nas outras lojas, e ela as revirara de alto a baixo. Era

11 A divisao do espaço em dois lugares distintos é freqüentemente representada pela presença de um obstáculo no olhar (linha do horizonte, muro) que delimita uma oposição entre o dentro e o fora; essa oposição, por sua vez, gera uma divisão dos objetos e dos sujeitos em presentes e ausentes [...] o objeto pode estar bem perto, à mão, ou mais longe, visível, mas inacessível sem deslocamento (Tradução nossa). 
uma corrente de platina, curta, simples e de modelo discreto, proclamando adequadamente seu valor por sua mesma substância e não por qualquer ornamentação espúria - como o devem fazer todas as coisas boas. Era digna até do Relógio. Tão logo a viu, soube que tinha de ser de Jim. Era como ele. Serenidade e valor - a descrição se aplicava a ambos. Vinte e um dólares cobraram-lhe por ela, e Della correu para casa com os oitenta e sete centavos. Com aquela corrente no relógio, Jim poderia preocupar-se decentemente com o tempo na frente de qualquer pessoa. Grande como era o relógio, ele às vezes o consultava meio envergonhado devido à velha tira de couro que usava em lugar de corrente.

Quando Della chegou a casa [...]”.

Do ponto de vista narrativo, o sujeito Della se coloca em movimento, munido de um querer ao anunciar sua busca ao sair do apartamento: "com um ruge-ruge de saias e coma centelha brilhante ainda nos olhos, correu para a porta e desceu rapidamente a escada que levava à rua". A saída do apartamento marca o deslocamento do sujeito e sua entrada em um espaço diferente, o que propicia uma disjunção espacial do espaço próprio e uma conjunção espacial com o espaço alheio. $\mathrm{O}$ "descer a escada" demonstra uma fronteira de demarcação de dois espaços particulares, permitindonos correlacionar os termos próprio vs alheio à categoria da interioridade vs exterioridade.

O espaço próprio é aquele comum ao sujeito Della e, por sua vez, o espaço alheio é aquele tido como "o vasto mundo onde se aventura o herói” (GREIMAS, 1993, p. 91). Tal saída marca o afastamento do espaço familiar e inaugura, ao mesmo tempo, a abertura de um espaço de busca, que é para $\mathrm{S}_{1} \mathrm{o}$ lugar de aquisição de objetos. No que concerne à movimentação do sujeito Della no espaço externo, temos uma construção dada segundo uma visualidade: "parou onde havia um letreiro anunciando" - uma operação cognitiva que permite a aquisição de um saber - e segundo uma exploração espacial "Della se pôs a vasculhar as lojas à procura de um presente para Jim” $e$ “nada havia que se lhe parecesse nas outras lojas, e ela as revirara de alto a baixo”.

Pela descrição dos ambientes interiores e exteriores, parece-nos oportuno dizer também, que cada uma dessas duas articulações categoriais permite depreender paixões (estados de alma) do sujeito, principalmente, quando o sujeito narrativo se relaciona a uma determinada figura do discurso que compõe a estrutura espacial. Alguns exemplos ilustram nossa afirmação:

- “Atirar-se no pequeno sofá puido e chorar”;

- “Afastou-se da janela e postou-se diante do espelho"; 
- "Permaneceu imóvel, enquanto uma ou duas lágrimas caíram sobre o puído tapete vermelho".

Nesse caso, as figuras (sofá, tapete, espelho) disseminadas ao longo do texto, além de criarem um liame entre a tessitura discursiva para a manutenção da isotopia da "mobília", elas relacionam-se diretamente a paixões do sujeito, e caracterizam a construção figurativa do espaço interior estabelecido pelo enunciador. O "apartamento" é o local onde são revelados estados interiores dos atores (Della e Jim) e, mais particularmente, as figuras (móveis), dotadas de “investimentos particularizantes, suscetíveis de produzir a ilusão referencial” (Greimas e Courtés, [1983], p. 223), provocam e acolhem reações passionais dos sujeitos.

Della, ao se olhar no espelho do apartamento, deixa aflorar um determinado comportamento (estado dealma): "subitamente afastou-se da janela e postou-se diante do espelho. Seus olhos estavam brilhantes, mas sua face perdeu a cor ao cabo de vinte segundos. Num gesto rápido, soltou o cabelo e deixou desdobrar-se em toda a sua extensão", ao chorar sob o tapete: "ela então o prendeu de novo, célere e nervosamente. A certo momento deteve-se e permaneceu imóvel, enquanto uma ou duas lágrimas caíam sob o puído tapete vermelho" e, ainda, quando Della caino sofá: "não havia evidentemente mais nada a fazer senão atirar-se ao pequeno sofá puído e chorar".

Seria pertinente afirmar, então, que são apresentadas, pela disposição figurativa da espacialidade do conto, as visões que Della tem do espaço que a rodeia. Essas figuras mencionadas desempenham o papel de atualizar comportamentos e de participar da configuração da existência dos atores do enunciado, isto é, de acordo com o modo que os objetos preenchem o espaço, os comportamentos dos sujeitos devem ser examinados erelacionados com o uso que fazem deles. É curioso observar, ainda, que o espaço pode ser semantizado pelas paixões desencadeadase desencadeadoras. Dessa forma, esse espaço é percebido pelo atores na medida em que constrói a competência modaldesses mesmos atores: eles querem, devem, podem, sabem; ou não.

Os pontos analisados até o momento fazem entender o estatuto semiótico da espacialidade e "as relações que o espaço mantém com ação romanesca, com os sujeitos, cuja identidade ela sustenta, com a axiologia e o conjunto de valores em jogo na narrativa" (BERTRAND, 2003, p. 144). Dessa forma, retomando a categoria espacial mais abstrata (interioridade vs exterioridade), o texto leva a ver todo o recobrimento figurativo que permite definir a isotopia da espacialidade em $O$ presente dos magos. A esse respeito Bertrand (2003, p. 146) afirma que 
a espacialidade, portanto, não controlaria somente uma ordem de representação icônica do mundo sensível, a topografia, o cenário, a percepção e os movimentos das personagens; ela formaria, ao mesmo tempo, uma 'topologia' mais abstrata, responsável por outras funções semânticas.

Dessa forma, aplicar tais noções teóricas significa encontrar na articulação discursiva uma categoria fundante do espaço que passa a ser figurativizada e, também, iconizada, reconhecendo uma hierarquia que rege a configuração espacial. No conto, comojá dissemos, a categoria interioridade vs exterioridade é considerada como base para a articulação espacial, figurativizada respectivamente por "apartamento" e "rua" e, por fim, iconizada por quantificações e qualificações, levando a produção de um efeito de sentido de realidade.

Devemos mencionar, outrossim, que, se pensarmos nos termos categoriais de articulação do nível fundamental do conto, dados como ausência vs presença, seria possível criar homologações que perpassariam os diversos níveis de construção do sentido. Dessa forma, para a categoria espacial eufórica exterioridade, teríamos no nível fundamental o termo presença articulado à conjunção com os objetos de valores no nível narrativo. Porsua vez, o mesmo se dá para a categoria espacial disfórica interioridade, homologável aos termos ausência e disjunção, dos níveis fundamental e narrativo respectivamente.

Fica à vista, portanto, um modo próprio de fazer ver uma dimensão espacial, afirmada pelo convite do narrador do texto: "enquanto a dona da casa gradualmente passa do primeiro ao segundo estágio, vamos dar uma espiada na casa". Descortina-se a movimentação dos atores do conto por um cenário que os acolhe eparticipa da construção de suas identidades emolduradas por comportamentos davida cotidiana.

\subsubsection{A actorialização}

Para o exame da actorialização do conto, devemos ter em mente que tal componente da discursivização está fundado nos procedimentos de debreagem e embreagem. Esses mecanismos instalam a pessoa que, depois de tematizada e figurativizada, converte-se em ator do discurso. $\mathrm{O}$ ator é, então, o ponto de convergência de investimentos semânticos do subcomponente sintáxico e 
semântico. Ademais, o uso dos recursos enunciativos e enuncivos de instalação das pessoas no discurso direciona-nos a atentar para a criação de determinados efeitos de sentido. A debreagem enunciativa cria um efeito de subjetividade pelas marcas da enunciação presentes no enunciado: apreciações de fatos, por exemplo. A debreagem enunciva, pela eliminação dessas mesmas marcas da enunciação, faz com que o discurso produza efeitos de sentido de objetividade. Não, portanto, se instalam os simulacros do ego-hic-nunc enunciativos.

Dessa forma, convém apresentar, se bem que de modo sumário, os diferentes níveis enunciativos que guiarão nossas discussões. O primeiro nível da enunciação tem como actantes o enunciador e o enunciatário. Esse é o nível da enunciação considerada como o quadro implícito e logicamente pressuposto pela própria existência do enunciado. (GREIMAS; COURTÉS, [1983], p. 125). O enunciador e o enunciatário são, por sua vez, o autor e o leito implícitos. Essa instância enunciativa será retomada mais detalhadamente quando tratarmos do éthos e do páthos dos contos de O. Henry.

O segundo nível da hierarquia enunciativa é a do destinador e do destinatário instalados no enunciado, ou seja, narrador e narratário, actantes da enunciação enunciada. É nesse ponto que iremos ater nossa atenção por ora, pois o trabalho com a análise de um único conto nos permite no momento obter um exame desses actantes da enunciação enunciada para, posteriormente, averiguarmos como narrador e narratário remetem ao enunciador e ao enunciatário dos textos de $\mathrm{O}$. Henry.

Analisar o narrador do conto é identificar por trás de quem o enunciador se esconde e mostrar que o enunciador ao projetar um tipo de narrador-observador está projetando a si mesmo. Cremos, assim, que a imagem do narrador projetada no conto $O$ presente dos magos remete e coincide com uma imagem de enunciador da obra de O. Henry. Estamos, por enquanto, no estabelecimento de um éthos hipotético que deve ser confirmado com o exame de outros contos do autor.

A noção de éthos pré-discursivo, instituída por Dominique Maingueneau ou éthos prévio para Ruth Amossy e Calit Haddad ${ }^{12}$, serve a nossos propósitos, pois o narrador ao apresentar "um certo posicionamento ideológico induz expectativas em matéria de ethos" (MAINGUENEAU, 2005, p. 71). Lidamos, nesse caso, com a construção de uma representação de uma imagem de enunciador. Buscando, dessa forma, confirmar as hipóteses expostas, temos como suporte teórico o segundo nível enunciativo, que abarca narrador e narratário. Podemos, assim, por meio da análise

12 Tais termos encontram-se em MAINGUENEAU, Dominique (2005). Éthos, cenografia, incorporação. In: AMOSSY, Ruth (org.). Imagens de si no discurso: a construção doéthos. São Paulo: Contexto, p.71. 
desses actantes, compreender a organização actorial de $O$ presente dos magos e demonstrar os efeitos de sentido criados pela instauração dos atores do discurso.

Pensemos, então, que toda enunciação pressupõe um eu que se projeta no enunciado seja sob a forma de um narrador em primeira pessoa, seja sob a forma de um narrador em terceira pessoa, pois como diz Fiorin (2002, p. 104) "na medida em que o narrador pode intervir a todo instante como tal na narrativa, toda narração é virtualmente feita em primeira pessoa". Vemos aí uma noção ampliada da enunciação enunciada.

No conto de O. Henry, percebemos que há um entremear de tais operações, pois o texto que ora é iniciado em terceira pessoa pela projeção do eu sob a forma de um ele, nos apresenta também intervenções explícitas de um eu-narrador. Notamos, portanto, que o texto, narrado em terceira pessoa, é permeado por intrusões e apreciações desse eu-narrador. Intrusões estas que se enfeixam em um conjunto de apreciações moralizantes feitas pelo narrador e que se ligam diretamente à enunciação, instância pressuposta da qual fazem parte enunciador/enunciatário. Afirmamos, com isso, que tratamos de analisar um conto em terceira pessoa povoado de interferências de um eu-narrador, o que colabora para a criação de uma malha narrativa de debreagens enunciativas e enuncivas.

Considerando a narração em terceira pessoa, o "ele", instalado no enunciado por meio de uma debreagem actancial enunciva, é figurativizado pelas personagens: "Della e Jim”. Temos aí a construção dos atores principais do texto por meio da assunção de qualificações descritivas que iconizam e apresentam a um só tempo estados narrativos: estados de falta e sujeitos de busca. A figura do casal introduz a debreagem enunciva e causa um efeito de objetividade pela eliminação das marcas da enunciação - simulacro "passageiro" do distanciamento do enunciador em relação aos fatos narrados. Isto implica em abster-se emocionalmente, ao menos no modo do parecer, dos acontecimentos do discurso. Figurativizado, então, pela determinação onomástica (Della e Jim), o casal de amantes surge instalado no discurso para determinar e individualizar os actantes do enunciado, fundar um efeito de verdade e conferir credibilidade ao dito.

Vemos, entretanto, que as seqüências de descrição das ações dos atores não são neutras, isto é, não se acham desprovidas de qualquer marca valorativa. O narrador, sempre após a apresentação dos fatos, lança mão de uma apreciação moralizante e, portanto, se confirma como um eu. Os exemplos são abundantes. Vejamos alguns:

1) Após a discursivização da situação socioeconômica do ator Della, no primeiro parágrafo, o narrador já demonstra no segundo valorações do que foi exposto: "Não havia evidentemente mais nada a fazer senão atirar-se ao pequeno sofá puído e chorar. Foi o que Della fez. O que leva à reflexão moral de que a vida é feita de soluços, fungadelas e sorrisos, com. 
predomínio das fungadelas" (grifo nosso). Observamos, nesse trecho, um narrador altamente avaliativo, que atribui uma apreciação às ações dos atores do enunciado. O tom assertivo, de afirmação, de asseveração é explicitado pelo narrador que, nesse caso, se constitui como um eunarrador pelas marcas da enunciação enunciada.

2) E ainda mais adiante:

"Quando Della chegou a casa, seu embevecimento cedeu lugar a um pouco de prudência e razão. Pegou os ferros de frisar, acendeu o gás e pôs-se a reparar os estragos causados pela generosidade acrescida ao amor. O que sempre é uma. tarefa muito árdua, queridos amigos - uma tarefa gigantesca" (grifo nosso).

O narrador, mais uma vez, emerge no meio do enunciado para impelir um determinado ponto de vista bem marcado em relação ao dito.

3) Um outro exemplo do texto reafirma nossas constatações: “A porta se abriu, Jim entrou e a fechou. Parecia magro e muito sério. Pobre sujeito, apenas vinte e dois anos e já. responsável por uma família! Precisava de um sobretudo novo e não tinha luvas" (grifo nosso). Esse processo enunciativo colocado no interior do enunciado ajuda acompor um conjunto de marcas identificáveis que remetem à instância da enunciação. Se evidenciarmos esse princípio, podemos examinar o trecho sublinhado recortando adjetivos, advérbios e substantivos que formam a enunciação enunciada: “pobre sujeito", “apenas”, “já responsável”.

4) Além disso, as intrusões, consideradas como deslocamento de pessoas, explicitam a presença do eu-narrador que convida um narratário a participar da narrativa e a acompanhar de perto as personagens e sua movimentação: "Enquanto a dona da casa gradualmente passa do primeiro ao segundo estágio, vamos dar uma espiada na casa. Um apartamento mobiliado, a oito dólares por semana. Não era exatamente miserável, mas tinha essa palavra pronta para o grupo de mendicância" (grifo nosso). A subjetividade existe quando verificamos a presença do narrador e a do narratário que remetem à instância da enunciação. A questão da conversa do narrador com o leitor merece ainda um outro esclarecimento. Ao estabelecer explicitamente o narratário no conto, por meio de uma relação de aproximação e de cumplicidade, temos a intervenção explícita da 
enunciação: "Perdoe-se a metáfora gasta" e "O que sempre é uma tarefa muito árdua, queridos amigos - uma tarefa gigantesca".

Por esses exemplos, conseguimos generalizar tal modo de dizer para o texto todo, uma vez que, como já mencionamos, por entre a tessitura discursiva emergem apreciações do narrador que evidenciam seu tom assertivo e que imprimem uma marca de pessoalidade, de aproximação à enunciação. A distância que, parecia haver entre enunciação e enunciado, principalmente pela abertura do texto em debreagem enunciva, se atenua e mostra laços de aproximação mais apertados.

O modo de construção do conto, no que concerne à instalação das pessoas no discurso, parece alicerçado em uma estrutura de composição que segue a seguinte fórmula: debreagens enuncivas (terceira pessoa/ele) para a narração das ações que tomam a dimensão de exposições de acontecimentos, seguida de debreagens enunciativas (primeira pessoa/eu) que se encarregam de avaliar valorativamente os percursos do atores. Encontramos, dessa forma, por meio do recurso da debreagem enunciativa, um narrador que comenta, em primeira pessoa, os acontecimentos e a narração, em um movimento em que a enunciação toma a palavra: “Esta asserção obscura será esclarecida mais tarde".

O ápice do julgamento do narrador se dá pelo final do conto, que mais lembra um final de uma fábula pelo tom de ensinamento e comportamento a ser valorizado e seguido.

\footnotetext{
"Os magos, como sabem, eram homens sábios - homens maravilhosamente sábios - que trouxeram presentes para a Criança na manjedoura. Inventaram a arte de dar presentes natalinos. Sendo eles sábios, seus presentes eram sem dúvida igualmente sábios. Possivelmente admitiam o privilégio de troca em caso de duplicação. E aqui lhes contei canhestramente a desimportante crônica de duas crianças tolas, num apartamento, as quais da maneira a mais insensata, sacrificaram, uma pela outra, os maiores tesouros de seu lar. Mas como derradeira palavra para os sensatos dos dias que correm, seja dito que, de todos que dão. presentes, os dois foram os mais sábios. Todos que dêem e recebam presentes como os deles são os mais sábios. Em toda parte, os mais sábios. São os magos.” (grifo nosso).
}

Nesse trecho, o narrador se mostra explicitamente pela desinência verbal de contei $\mathrm{e}$ inicia um julgamento em relação à troca de presentes e ao sacrifício feito pelos atores Della e Jim. 
Nessa avaliação, a conotação tímica eufórica aparece homologada ao percurso narrativo desempenhado pelos actantes-sujeitos e é confirmada pelo tema do sacrifício. O narrador não repugna explicitamente um comportamento, mas ao contrário, mostra ao leitor as virtudes de determinadas ações humanas e de uma conduta passível de ser seguida. $\mathrm{O}$ tom de ensinamento também permeia o excerto: "todos que dêem e recebam presentes como os deles são os mais sábios". Direciona-se ao narratário um comportamento eufóricoque pode e deve ser assimilado. Além disso, a timia incinde sobre os próprios conteúdos investidos e, nos moldes de Greimas e Courtés ([1983],p. 286), “ela aparece como um dos aspectos do fenômeno mais geral da axiologização".

Podemos afirmar, desse modo, que pelas interferências, comentários e avaliações, o narrador se manifesta dotado do traço + /onisciência/, já que o sincretismo com o observador permite uma visão total dos fatos narrados. Tal característica liga-se diretamente à questão do poder e do saber. Um narrador que pode conduzir seu discurso de um modo particular e que possui um determinado saber como competência modal definida para o narrar, isto é, um sujeito que deve e pode assumir sua palavra e que demonstra um saber de seu papel de narrador para a apresentação de uma visão ideológica de mundo.

Além disso, a descrição feita pelo narrador, que se vincula diretamente à atividade perceptiva, também revela traços de subjetividade e um ponto de vista bem orientado. Como afirma Bertrand (2003, p. 115, “o ponto de vista é, pois, regido pelo observador eseu modo de presença enunciativa". Reafirmamos aqui que o observador do conto está emsincretismo com o narrador. Dessa forma, a disposição dos elementos dadescrição revela um modo de apreensão do mundo narrado e, conseqüentemente, também do narrador. É o narrador-observador que conduz o narratário a ver, perceber e a localizar os elementos na disposição narrativa. Ainda, esse ponto de vista designa a expressão de um juízo, de uma opinião, de uma tomada de posição.

Essa posição em O presente dos magos é sustentada pela maneira como o discurso é instalado, ora com debreagens enunciativas, ora com debreagens enuncivas, pela proposição e afirmação de argumentos. Vemos, assim, ser construído o alicerce do texto de O. Henry pela gradação da ativação dos recursos de debreagem. O fenômeno da focalização interna se dá quando o narrador/observador acompanha Della em seu percurso de aquisição de objeto-valor. Introduzem-se valores passionais (sacrifício dado segundo o amor) que comandam a organização dos elementos figurativos enfeixados linearmente para o desenrolar da narrativa, assegurado pelo desenvdvimento narrativo do ator Della.

Em suma, a respeito do observador, Bertrand (2003,p. 126) assume que 
Os tipos de observador se depreendem da discursivização dos atos de conhecimento. Eles implicam por isso mesmo, uma atividade perceptiva. Esta pode ser explicitada por meio de predicados da percepção (ver, envolver com o olhar, perceber, explorar examinar, etc.) que definem a natureza do ato, a estratégia utilizada e o papel atribuído ao observador. Ela pode igualmente ser induzida pela disposição dos objetos, pelo modo de sua seleção, pela estruturação das diferentes partes em relação à totalidade visada.

Parece que é o que justamente acontece no conto. O narrador/observador faz ver por meio de predicados de percepção, "vamos dar uma espiada na casa”, "por dez segundos, contemplemos, com discreta atenção, qualquer objeto inconseqüente, noutra direção” e também pela disposição de objetos, "num gesto rápido, soltou o cabelo e deixou desdobrar-se em toda a sua extensão" (grifo nosso). O observador vê em $O$ presente dos Magos "as relações, os engates e desengates, a seqüência ininterrupta das conjunções e disjunções, as esperas percebidas como causas, os objetivos últimos dos deslocamentos, enfim, toda essa micronarratividade que tem por atores as máquinas”(BERTRAND, 2003, p. 135).

Estreitando a análise, é possível observar ainda no conto algumas funções desempenhadas pela presença do narrador. Temos como exemplo de uma primeira função, o convite feito pelo narrador para que o narratário acompanhe o desenrolar da narrativa. Instalam-se no enunciado os actantes da enunciação (eu/tu) configurando aquilo que Fiorin chama de função de comunicação: "vamos dar uma espiada na casa", "talvez o leitor já tenha visto um espelho de tremó num apartamento de oito dólares", "o que sempre é uma tarefa muito árdua, queridos amigos - uma tarefa gigantesca" e "já apresentada ao leitor como Della. O que está muito bem”. Assim, "a função de comunicação reside numa orientação para o narratário, quando o narrador conversa com ele, imagina suas reações, etc" (FIORIN, 2002, p. 106).

Podemos observar ainda, seguindo as tipologias expostas por Fiorin (2002), uma outra função, a de atestação que é "aquela que fala da relação afetiva, moral ou intelectual do narrador com a história" (FIORIN, 2002, p. 106). Em nosso caso, essa função tem o papel de indicar os sentimentos que os episódios narrados despertam no narrador. Podemos comprovar esse recurso narrativo pelas constantes observações do narrador em relação ao narrado: "não havia 
evidentemente mais nada a fazer senão atirar-se ao pequeno sofá puído e chorar. Foi o que Della fez. O que leva à reflexão moral de que a vida é feita de soluços, fungadelas e sorrisos, com. predomínio das fungadelas" (grifo nosso). Nesse exemplo, notamos que, logo após uma exposição narrativa, emerge uma atestação sentimental ligada ao fato.

E, por fim, uma função ideológica também está presente no texto. O narrador avalia ideologicamente as ações do conto a partir do ponto de vista de uma visão de mundo. Nesse sentido, Bertrand (2003, p. 112) afirma que "não há enunciado qualquer que seja sua dimensão, que não esteja submetido à orientação de um ponto de vista", já que "o ponto de vista engloba, ao mesmo tempo o modo de presença do enunciador em seu discurso e a maneira pela qual ele dispõe, organiza e orienta seus conteúdos" (BERTRAND, 2003, p. 112).

O uso da debreagem enunciava para instalar os atores do enunciado (Della e Jim) e o desenvolvimento de seus percursos já implica um ponto de vista na estruturação da narrativa. A própria focalização dada ao ator Della é de grande importância, pois é a partir dessa escolha que o conjunto narrativo vai se organizar. Dessa forma, a seleção de um ator que porta o traço da feminilidade marca no discurso uma ideologia que coloca em cena valores ligados aos sacrifícios matrimoniais feitos pela mulher. Temos a ideologização da mulher segundo ideais do senso comum, que apagam contradições e desestabilizações de papéis sociais.

Devemos nos referir, ainda, ao terceiro nível da hierarquia enunciativa. Nesse nível, o enunciador dá voz a um actante do enunciado pela operação chamada de debreagem de segundo grau, isto é, os actantes tomam voz por meio de uma debreagem interna. Cria-se, dessa forma, o diálogo, como um simulacro da estrutura da comunicação no interior do discurso, pela projeção de um interlocutor e de um interlocutário. Verificamos que os diálogos ao fundar uma estrutura do real servem como "meio de passar a responsabilidade do que é dito àquele que se cita em discurso direto" (BARROS, 2001, p. 76).

Em O presente dos Magos, os diálogos revelam ainda uma característica particular. Notamos falas lacônicas, tomadaspelo cansaço de existir. Há o predomínio de expressões contidas o que resulta em um plano da expressão que se fundamenta em silêncios que recortam as falas. As falas dos atores em discurso direto, na sua pouca freqüência e na sua não prolixidade, confirmam, por sua vez, o mundo em que nem tudo precisa ser explicitado. Reproduzimos, em seguida, um trecho que representaessa estrutura peculiar do diálogo no conto. 
“- Mandou cortar o cabelo? - perguntou Jim a custo, como se não se tivesse ainda compenetrado desse fato patente após o mais árduo esforço mental.

- Cortei-o e vendi-o - disse Della. - Você não continua a gostar de mim do mesmo jeito, então? Estou sem cabelo, não estou?

Jim olhou à volta do aposento de modo curioso.

- Você diz que seu cabelo se foi? - insistiu, com um ar de quase idiotia.

- Não precisa procurar por ele - disse Della. - Foi vendido, como lhe disse..."

O mundo da falta se perpetua pelo modo de reproduziro discurso dos atores quando relatados em discurso direto. Temos atores com pouca voz, com pouca extensão devoz, o que os torna concentrados em um universo de poucas justificativas. Quanto ao discurso indireto, o narrador tem o controle da narrativa com eventuais demonstrações de discurso indireto livre, quando a fala da personagem invade a voz do narrador.

O emprego do discurso indireto livre perpassa todo o conto e pode ser confirmado pelos seguintes exemplos:

a) "Oh, as duas horas seguintes voaram com asas róseas";

b) “A porta se abriu, Jim entrou e a fechou. Parecia magro e muito sério. Pobre sujeito, apenas vinte e dois anos e já responsável por uma família! Precisava de um sobretudo novo e não tinha luvas";

c) "Ouviu-se então um grito estático de alegria, e depois, aị!, uma súbita mudança feminina para as lágrimas e os gemidos, que exigiram o imediato emprego de todos os poderes de consolação do senhor do apartamento".

O enunciador instala, portanto, um leitor-narratário altamente participativo, cooperativo em um emparelhamento dos corpos do narrador com o do narratário por meiode um convite a uma movimentação própria e por meio de uma proxêmica equivalente para ambos os sujeitos.

Interessante notar que, a análise feita do narrador e, conseqüentemente do narratário, faz com que nos aproximemos do enunciador edo enunciatário do texto, uma vez que narrador e narratário são sujeitos diretamente delegados do enunciador e do e enunciatário. Dessa forma, a disposição desses actantes da enunciação enunciadano conto $O$ presente dos Magos ajuda a controlar os modos de 
acesso à significação para o leitor. As seleções operadas pelo enunciador orientama apreensão dos sentido e dos valores. Assim, o próprio fato de organizar seus textos com esse tipo de narrador, levanos a verificar uma remissão ao enunciador do conto e, por conseqüência, de uma totalidade de enunciados pressuposta.

\subsubsection{A temporalização}

Na questão da temporalização pretendemos verificar o enlaçamento temporal usado para a construção do conto de O. Henry e observar, a partir dessa articulação, um encaixamento entre o uso dos tempos na criação de efeitos de sentido. Na base da articulação temporal, vemos então que "o discurso instaura um agora, momento da enunciação. Em contraposição ao agora, criase um então. Esse agora é, pois, o fundamento das oposições temporais da língua" (FIORIN, 2002, p. 142). Ainda, como afirma Fiorin (2003, p. 167):

Existem na língua dois sistemas temporais: um relacionado ao momento de referência presente e, portanto, diretamente ao momento da enunciação, já que o momento de referência presente é concomitante ao momento da enunciação, e outro ordenado em função de momentos de referência passado ou futuro instalados no enunciado.

Essa afirmação aparece bem nítida no conto, uma vez que os tempos do texto são ora organizados em função do agora, ora organizados em função do então. Ao estabelecer o narrado, os tempos são todos enuncivos - pretérito perfeito 2 e pretérito imperfeito, por exemplo; ao apresentar as falas do narrador no narrado dizendo $e u$, são todos enunciativos com predominância do tempo presente.

Inicialmente, podemos detectar o uso de duas categorias para o tempo passado: o pretérito imperfeito e o pretérito perfeito 2, ambos enuncivos, centrados em um momento de referência pretérito. Esses dois tempos foram instalados por uma debreagem enunciva da 
enunciação. O enunciador ao projetar essa categoria de tempo no conto, estabelece a narração com o pretérito perfeito 2, pois apresenta estados ou transformações sucessivos:

"Vestiu o velho casaco marrom; pôs o velho chapéu marrom. Com um ruge-ruge de saias e com a centelha brilhante ainda nos olhos, correu para a porta e desceu rapidamente a escada que levava à rua.

Parou onde havia um letreiro anunciando: "Mme Sofronie, Artigos de Toda Espécie para Cabelos". Della subiu a correr um lance de escada e se deteve no alto, arquejante, para recompor-se".

Do mesmo modo, a presença do pretérito imperfeito é recorrente, o que demonstra uma descrição. A respeito disso, Fiorin (2003, p.171)atesta que:

O imperfeito, ao contrário, apresenta fatos como simultâneos, como formando um quadro contínuo, ou melhor, como vinculados ao mesmo momento de referência pretérito. Por isso, é o tempo que melhor atende aos propósitos da descrição.

Além desses dois usos predominantes, verificamos, ainda, uma riqueza nos movimentos temporais construídos no conto seja pela presença de embreagens, seja pela movimentação do narrado no subsistema da anterioridade.

Em relação à embreagem, temos um "efeito de retorno à enunciação, produzido pela suspensão da oposição entre certos termos da categoria de pessoa e/ou do espaço e/ou do tempo, bem como pela denegação da instância do enunciado" (GREIMAS e COURTÉS, [1983], p. 140). No que concerne à embreagem temporal no conto, alguns exemplos podem ser evidenciados: "Enquanto a dona da casa gradualmente passa do primeiro ao segundo estágio, vamos dar uma espiada na casa" (grifo nosso) - uso do presente pelo pretérito, e "Estivera a economizar tostão por tostão havia meses, e esse era o resultado. Vinte dólares por semana não dão para nada" (grifo nosso) - uso do presente pelo passado imperfeito.

Do subsistema temporal da anterioridade, alguns empregos verbais também podem ser elucidados: 
"Morara a Rainha de Sabá no apartamento do outro lado do poço de ventilação, $e$ Della teria algum dia deixado o seu cabelo cair fora da janela para secá-lo e depreciar assim as jóias e as riquezas de Sua Majestade. Fora o Rei Salomão o zelador, com todos os seus tesouros empilhados no porão, e Jim teria puxado o relógio cada vez que por ele passasse, só para vê-lo arrancar as barbas de inveja" (grifo nosso).

Dessa forma, o narrado se movimenta no sistema enuncivo, dado sob o MR pretérito ora perpassando pela concomitância em relação ao MR pretérito instalado no enunciado, ora em relação de não concomitância ao MR pretérito. Temos como exemplo o seguinte trecho: "No vestíbulo embaixo havia uma caixa de correspondência na qual carta nenhuma seria posta, e um botão de campainha que nenhum dedo mortal jamais apertaria" - estamos diante aqui, nesse exemplo, de um MR pretérito (subsistema da anterioridade), não concomitante, posterior e perfectivo (futuro do pretérito composto).

O que pode, também, ser considerado como peça importante nessa articulação dos tempos, é a presença do dêitico temporal "véspera de Natal". A ancoragem temporal "véspera de Natal" possui, então, a função de determinar e mover temporalmente alguns acontecimentos da narrativa. Em relação aos advérbios e locuções adverbiais, Fiorin (2002,p. 162) vai dizerque:

Os advérbios de tempo articulam-se também em um sistema enunciativo e enuncivo. Aquele centra-se em um momento de referência presente, idêntico ao momento da enunciação; este organiza-se em torno de um momento de referência (pretérito ou futuro) inscrito no enunciado, o que significa que o que tange aos advérbios não existe um subsistema relacionado a um MR pretérito e outro, a um MR futuro. A cada um dos momentos de referência (enunciativo e enuncivo) aplica-se a categoria topológica concomitância vs não-concomitância (anterioridade vs posterioridade).

Para comprovar o uso dos tempos enuncivos e que, particularmente, se organizam em relação ao marco temporal "no dia seguinte seria Natal", averiguamos que a posteridade se dá em função de: $e m+$ artigo definido + nome designativo de divisão de tempo ou nome de intervalo temporal + seguinte, como exemplificado pelo trecho: "Três vezes Della contou o dinheiro. Um 
dólar e oitenta e sete centavos. E no dia seguinte seria Natal". Assim, a posterioridade é indicada por meio do marco referencial futuro "no dia seguinte". O futuro anterior (futuro do pretérito) representa uma anterioridade, não concomitância em relação ao MR futuro.

Interessante averiguarmos, ainda, o uso da expressão adverbial amanhã, em "amanhã seria Dia de Natal', instalada no enunciado. Fiorin (2002, p. 166) apresenta uma explicação para tal emprego:

Cabe lembrar, no entanto, que é possível usar conjuntamente um tempo verbal e uma expressão adverbial temporal que não pertencem ao mesmo sistema de referência, quando dois momentos distintos de referência estiverem implicados.

Dessa forma, como o momento de referência é a "véspera de Natal", isto é, um dia anterior ao Natal, esse amanhã indica o uso de um tempo verbal e de uma expressão adverbial temporal que não pertencem ao mesmo sistema de referência, pois dois momentos distintos de referência estão implicados.

A temporalização do conto, enquanto enriquecimento dos níveis anteriores, pemite comprovar, assim, a direção narrativa estabelecida pelo nível narrativo. Se, averiguamos um sujeito de busca (Della) que estabelece um percurso para suprir uma determinada falta no nível narrativo, podemos dizer que, no que concerne à instalação do tempo no conto no nível discursivo, verbos de direcionalidade revestem tal busca, isto é, o percurso narrativo dos sujeitos.

Essa direcionalidade é desenvolvida pela instalação e encaixamento de verbos como: “atirar-se”, “passa”, “terminou”, “cuidou”, “postou-se”, “afastou-se”, “soltou”, “vestiu-se”, “correu”, “desceu”, “subiu”, "pôs a vasculhar”, “encontrou”, “chegou”, etc. Esses exemplos demonstram que os verbos instalados pela debreagem enunciva conduzem a narrativa e estabelecem o eixo da prospectividade, isto é, sempre em frente para a aquisição do objeto. Tal direcionalidade demonstrada por alguns verbos nos leva a notar ainda a presença de uma aspectualização que revela a presença implícita de um observador. Como afirmam Greimas e Coutés ([1983], p. 29) "o efeito de aspectualidade resulta do investimento de categorias aspectuais que convertemas funções (ou predicados) dos enunciados narrativos em processo". É introduzido, assim, um actante observador "para quem a ação realizada por um sujeito instalado no discurso aparece como um processo, ou 
seja, como uma 'marcha', um desenvolvimento" (Idem). Por isso que é privilegiado o uso do pretérito imperfeito.

Em $O$ presente dos magos a presença do observador deixa-se apreender, então, por meio desse sujeito cognitivo que observa o fazer. Curioso notar ainda que ao lado dos tempos verbais que denotam aspectos encontramos também advérbios de aspecto. A esse respeito Fiorin (2002, p.168) atesta que "assim como o sistema verbal distingue formas para expressar no âmbito de uma dada relação temporal, os aspectos pontual e durativo (contínuo e iterativo), bem como o acabado e o inacabado, o sistema adverbial apresenta também advérbios de aspecto" (grifo do autor)

Encontramos, então, no texto, na sua grande maioria, advérbios que denotam o aspecto pontual: "subitamente", "num gesto rápido", "rapidamente”, “depressa”, "tão logo”. Esses advérbios pontuais de acordo com Fiorin $(2002,168)$ "por indicar a descontinuidade que irrompe na continuidade, servem muitas vezes, associado ao perfeito 2, para marcar o início das transformações que se dão em meio a um estado apresentado pelo pretérito imperfeito".

O deslocamento narrativo do sujeito Della, dessa maneira, é enriquecido no nível discursivo por esses advérbios pontuais. Eles afirmam o olhar do observador no deslocamento do sujeito e demarcam um modo de presença no decurso das ações dos atores do enunciado. Assim, a aspectualização dos verbos é reforçada e intensificada pelo emprego dos advérbios: "gradualmente passa", "subitamente, afastou-se", "num gesto rápido, soltou”, "tão logo a viu”, "Jim pareceu despertar rapidamente", etc. O emprego dos advérbios aparececom maior freqüência na primeira parte do texto, pois as ações que iniciam o conto são aquelas debusca de objetos. Dizemos, assim, que há também uma aceleração no inicio do texto e uma desaceleração em seu final. Tal cadência do ritmo narrativo é atestada por muitos dos recursos que já expusemos aqui. A aceleração pode ser afirmada também no plano da expressão pelas falas lacônicas do narrador que apresentam pouco fôlego de voz, imprimindo um andamento narrativo rápido.

Podemos observar assim duas grandes seqüências no texo: a primeira sendo aquela que vai do início do conto até oretorno de Della ao apartamento: “um dólar e oitenta e sete centavos. Era tudo. E sessenta centavos eram emmoedas" até "quando Della chegou a casa...". E a segunda seqüência refere-se à chegada de Della ao final do texto: "quando Della chegou a casa, seu embevecimento cedeu lugar a um pouco de prudência e razão" até "todos que dêem e recebam presentes como os deles são os mais sábios. Em toda parte, os mais sábios. São os magos".

A primeira seqüência apresenta-secomo bastante aceleradapelo uso recorrente de advérbios e verbos que denotam deslocamento rápido. A conjunção com os objetos, tida como 
necessidade extrema para agradar o marido, rege o motivo da aceleração. As ações são velozes, assegurando um início turbulento ao conto, e o tempo passa rápido: “Oh, as duas horas seguintes voaram com asas róseas". Na seqüência seguinte, quando a conjunção já está estabelecida, há uma desaceleração, diminui-se radicalmente o uso dos advérbios e as ações transcorrem mais lentamente, "seu embevecimento cedeu lugar a um pouco de prudência e razão" e "ao cabo de quarenta minutos, sua cabeça estava coberta de pequenos caracóis cerrados, que a faziam parecer, admiravelmente, um menino vadio".

A desaceleração propicia e realça ainda um efeito de suspense instaurado na segunda parte do texto, pois, antes de terminada a troca de presentes, há um prolongamento, uma suspensão no desfecho da narrativa. O desvelar de um "mistério" é o resultado do suspense, o que propicia dramaticidade ao discurso. Como afirmam Greimas e Courtés ([1983], p. 448) "para a semiótica, a suspensão surge como um dos 'propulsores dramáticos' do discurso narrativo". Desde o começo do conto, com a instauração da falta, há o início da criação de um suspense baseado emuma expectativa em função da liquidação dessa mesma falta. Essa suspensão que fundaum segredo levanos a identificar uma estratégia enunciativa com a finalidade de obter uma adesão peculiar do enunciatário ao texto. $\mathrm{O}$ enunciador propicia o saber sobre o desenrolar da narrativa paulatinamente. Essa gradação (desaceleração no fornecimento de informações) estende o discurso e adia a verdade.

\footnotetext{
O procedimento parece mais elaborado e mais complexo ainda quando, por exemplo, a suspensão da modalização epistêmica faz surgir, num momento dado, um fazer informativo neutro, provocando assim uma "inquietação no enunciatário", abandonado na ignorância do estatuto veridictório do saber recebido (GREIMAS e COURTÉS, [1983], p. 448 - 449).
}

A suspensão e o segredo criados pela desaceleraçãoe, conseqüentemente, pela elasticidade do discurso, mantém o enunciatário na "isotopia do secreto". O mistério toma fôlego no momento em que Jim vê Della com os cabelos cortados. A partir daí, o segredo começa a se arrastar e uma lentidão na narrativa é instaurada. O diálogo estabelecido em torno do "corte do cabelo de Della" é a peça que engendra todo o suspense. A segunda seqüência já se institui pela introdução dos acontecimentos em torno do lexema cabelo, aqui entendido como uma das figuras-chave da narração, assim como, a figura do relógio. Vejamos: 
1. “Ao cabo de quarenta minutos, sua cabeça estava coberta de pequenos caracós cerrados, que a faziam parecer, admiravelmente, um menino vadio";

2. "Ouviu então seus passos no primeiro lance da escada e empalideceu por um instante”;

3. "A porta se abriu, Jim entrou e a fechou";

4. "Seus olhos estavam fitos em Dela e havia neles uma expressão que ela não conseguia ler e que a aterrorizava";

5. "Mandei cortar o cabelo e o vendi porque não poderia passar o Natal sem dar um presente a você. Ele crescerá de novo... não se aborreça, por favor. Eu tinha de fazer isso. Meu cabelo cresce terrivelmente depressa";

6. “- Mandou cortar o cabelo? - perguntou Jim a custo”;

7. “-Cortei-o e vendi-o - disse Della. - Você não continua a gostar de mim do mesmo jeito, então? Estou sem cabelo, não estou?";

8. "Jim olhou à volta do aposento de modo curioso";

9. “-Você diz que seu cabelo se foi?";

10. “- Não precisa procurar por ele-disse Della. - Foi vendido, como lhe disse...”;

11. "Emergindo do seu transe, Jim pareceu despertar rapidamente";

12. "Jim tirou um pacote do bolso do sobretudo e atirou-o sobre a mesa";

13. “- Não me interprete mal, Della-disse”;

14. "Alvos dedos ligeiros desfizeram o atilho e o embrulho. Ouviu-se então um grito estático de alegria, e depois, ai!";

15. "Pois sobre a mesa jaziam Os Pentes - o jogo de pentes para cabelos que Della adorara havia muito numa vitrine da Broadway".

Percebamos, assim, mais detidamente a evolução das ações no engendramento do suspense, em nosso caso, por conta de um segredo. Em relação ao segredo, Bertand (2003, p. 241) diz que "um segredo só faz sentido se, de uma maneira ou de outra, puder ser descoberto, traído ou revelado".

Por fim, resta-nos averiguar ainda a instalação do tempo presente no texto. Aqui, queremos apresentar o emprego particular desse tempo nas intrusões do narrador no 
desenvolvimento das ações. Dessa forma, do sistema enunciativo, podemos destacar esse tipo de presente que reporta à enunciação por meio de uma opinião.

Alguns exemplos nos ajudam a elucidar tal uso:

1. "O que leva à reflexão moral de que a vida é feita de soluços, fungadelas e sorrisos, com predomínio das fungadelas".

2. "Mas sempre que Mr. James Dillingham Young voltava para casa e chegava ao seu apartamento lá em cima, era chamado de "Jim” e carinhosamente abraçado por Mrs. James Dillingham Young, já apresentada ao leitor como Della. O que está muito bem”.

3. "Vinte dólares por semana não dão para nada. As despesas tinham sido maiores do que calculara. Sempre são"”.

4. "Pegou os ferros de frisar, acendeu o gás e pôs-se a reparar os estragos causados pela generosidade acrescida ao amor. O que sempre é uma tarefa muito árdua, queridos amigos - uma tarefa gigantesca”.

5. "Todos que dêem e recebam presentes como os deles são os mais sábios. Em toda parte, os mais sábios. São os magos".

Estamos diante de uma debreagem enunciativa que marca uma coincidência entre o momento do acontecimento e o momento de referência presente. Como estamos na presença de asserções do narrador, o uso do presente omnitemporal ou gnômico é o mais apropriado. Um presente em que o momento de referência é ilimitado e, portanto, também é o momento de acontecimento. Como afirma Fiorin (2002, p. 151) "é o presente utilizado para enunciar verdades eternas ou que se pretendem como tais. Por isso é a forma verbal mais utilizada pela ciência, pela religião, pela sabedoria popular (máximas e provérbios)". Dessa forma, se na actorialização temos um eu-narrador que avalia os atos dos atores do enunciado e não se assume como pessoa que narra a própria vida, na temporalização, tal narrador lança mão do tempo presente ilimitado para cunhar as apreciações fincadas na "sabedoria" do enunciador.

\subsubsection{A tematização e a figurativização}


Lembrando que os valores assumidos pelo sujeito no nível narrativo disseminam-se sob a forma de temas e figuras no nível discursivo, cumpre-nos agora detectar alguns percursos figurativos no texto de O. Henry e chegar a alguns temas de maior relevância para nossa análise.

A tematização é um procedimento de conversão semântica que possibilita formular abstratamente valores. A esse respeito, Barros (2001, p. 115) afirma que a "tematização é a formulação abstrata dos valores, na instância discursiva, e sua disseminação em percursos”. Dessa forma, é a tematização que assegura a conversão da semântica narrativa em semântica discursiva. Isso nos direciona a observar no conto $O$ presente dos magos o procedimento de conversão dos valores de ausência vs presença do nível fundamental, disjunção e conjunção do nível narrativo em temas e figuras no nível discursivo. Para Bertand (2003, p. 431) a tematização é uma "operação que consiste em reconhecer, a partir de uma ou várias isotopias figurativas, uma isotopia mais abstrata, subjacente aos conteúdos figurativos cuja significação global ela condensa, orientando-a e integrando-lhe valores". Dessa forma, a questão das isotopias relaciona-se diretamente à da disseminação dos temas via figuratividade.

A figurativização, por sua vez, é compreendida como um novo "investimento semântico pela instalação de figuras do conteúdo que se acrescentam, 'recobrindo-o', ao nível abstrato dos temas" (BARROS, 2001, p. 116). Importante ressaltar também que o processo de figurativização compreende dois patamares: o primeiro patamar relaciona-se à figuração, isto é, à instalação das figuras semióticas e o segundo diz respeito à iconização, "que visa a revestir exaustivamente as figuras, de forma a produzir a ilusão referencial que as transformaria em imagens do mundo" (GREIMAS E COURTÉS, 1983, p. 187).

O primeiro tema reconhecido por um percurso figurativo do conto é aquele que se refere à falta socioeconômica. $\mathrm{O}$ tema socioeconômico da vida urbana é identificado pelas figuras que remetem à disjunção com o dinheiro. A dificuldade financeira na qual se encontrava o casal permeia todo o conto e pode ser comprovada pelas seguintes figuras: "moedas economizadas uma a uma", "pechinchando", "pequeno sofá puído", "caixa de correspondência na qual carta nenhuma seria posta", "um botão de campainha que nenhum dedo mortal jamais apertaria", "a receita baixara", "economizar tostão por tostão", "havia meses despesas tinham sido maiores", "puido tapete vermelho", "o velho casaco marrom" e "velho chapéu marrom". Tais figuras espalhadas pelo texto estabelecem um contexto que constrói as condições de vida de uma classe trabalhadora empobrecida. Atores que levam uma vida em falta, em disjunção, em despossessão, enfim, constituem o foco discursivo.

A falta de dinheiro comprova, então, o tema da despossessão econômica retratado no conto: 
“O 'Dillingham' fora acrescentado durante um anterior periodo de prosperidade, quando seu possuidor estava ganhando trinta dólares por semana. Agora, que a receita baixara para vinte dólares, as letras de "Dillingham" pareciam nubladas, como se estivessem pensando seriamente em abreviar para um modesto $e$ despretensioso D." (grifo nosso).

Atrelado a isso, surgem ideais burgueses referentes a trabalho, sucesso e aparência: "Com aquela corrente no relógio, Jim poderia preocupar-se decentemente com o tempo na frente de qualquer pessoa". Nesse sentido, fetichizam-se, ainda, os objetos-valor "Relógio" e "Pentes" detectados no plano da expressão com letra maiúscula.

Um outro tema possível de ser reconhecido refere-se ao sacrifício por amor. Tal tema faz pressupor uma troca, já que se espera algo pelo sacrifício realizado: seja reconhecimento, seja retribuição. Em O presente dos magos, o sacrifício feito por ambos os atores refere-se ao fato de eles terem vendido os bens que mais valorizavam para agradar um ao outro: "ora, os James Dillingham Youngs tinham dois haveres de que muito se orgulhavam. Um era o relógio de ouro de Jim, que pertencera a seu pai e a seu avô. O outro era o cabelo de Della" (grifos nosso).

A venda desses bens institui um ato que, mais uma vez, reporta a uma despossessão material. Esta é a base do sacrifício no texto de O. Henry: abrir mão do que se tem de mais valioso em função do outro: “- Não precisa procurar por ele - disse Della. - Foi vendido, como lhe disse... vendido, não está mais aqui. É Véspera de Natal, querido. Seja bonzinho comigo, fiz isso por sua. causa” (grifo nosso). Nessa esteira, Fontanille e Zilberberg (2001, p.271) tecem comentários em relação ao sacrifício: "Tanto quanto a ascese, o sacrifício é uma renúncia que se torna condição da oferenda, numa relação de troca gentil e interessada".

Ainda, nos dizeres dos mesmos autores, o sacrifício articula-se a partir de uma tensão para a disjunção. Della, para poder comprar o presente para o marido deve entrar em disjunção com seu cabelo, o que é motivo para a criação de uma tensão: “o cabelo de Della, pois, caiu-lhe pelas costas, ondulando e brilhando como uma cascata de águas castanhas. Chegava-lhe abaixo do joelho e quase lhe servia de manto. Ela então o prendeu de novo, célere e nervosamente. A certo momento, deteve-se e permaneceu imóvel, enquanto uma ou duas lágrimas caíam sobre o puído tapete vermelho" (grifo nosso). 
O tema do sacrifício une-se ainda ao tema da sabedoria explicitado no último parágrafo do conto:

\begin{abstract}
"Os magos, como sabem, eram homens sábios - homens maravilhosamente sábios - que trouxeram presentes para a Criança na manjedoura. Inventaram a arte de dar presentes natalinos. Sendo eles sábios, seus presentes eram sem dúvida igualmente sábios. Possivelmente admitiam o privilégio de troca em caso de duplicação. E aqui lhes contei canhestramente a desimportante crônica de duas crianças tolas, num apartamento, as quais da maneira a mais insensata, sacrificaram, uma pela outra, os maiores tesouros de seu lar. Mas como derradeira palavra para os sensatos dos dias que correm, seja dito que, de todos que dão presentes, os dois foram os mais sábios. Todos que dêem e recebam presentes como os deles são os mais sábios. Em toda parte, os mais sábios. São os magos”.
\end{abstract}

Dessa maneira, estamos diante do tema da excelência ou da magnitude da sabedoria, possível de ser aproximado do termo "Phronesis" usado por Aristóteles para descrever a "sabedoria prática" ou a "habilidade para agir de maneira acertada"13. Explicita-se, assim, por meio desse tema, uma virtude orientada a um habitus positivo a ser seguido. Uma verdade e uma qualidade atestada pelo discurso em função de uma moralidade apoiada em um "conselho": "mas como derradeira palavra para os sensatos dos dias que correm, seja dito que, de todos que dão presentes, os dois foram os mais sábios. Todos que dêem e recebam presentes como os deles são os mais sábios". Afirma-se um olhar benevolente e uma ingenuidade dos atores do enunciado. Ingenuidade esta que é recuperada como sabedoria, pois os atores do enunciado apresentam-se com prontidão, por meio da conjunção com um saber peculiar.

Averiguando, mais especificamente, o final do conto, encontramos aquilo que, no nível narrativo, caracterizamos como a "troca" de objetos. Dessa forma, ao final de nosso exame da dinâmica dos objetos inscritos no conto, observamos que no enunciado o objeto de valor descritivo figurativizado como "corrente de relógio" e "pentes" mantém os traços semânticos do lexema "presente", ou seja, algo para ser oferecido, gerando alegria, surpresa, satisfação, felicidade. No entanto, a enunciação desconstrói esse núcleo sêmico: O. Henry apresenta um presente que não se cumpre.

13 Os termos entre aspas foram baseados no artigo de EGGS, Ekkehard. Éthos aristotélico, convicção e pragmática moderna. In: AMOSSY, Ruth (Org.). Imagens de si no discurso: a construção do éthos. São Paulo: Contexto, 2005. 
Paixões da falta e da incompletude como decepção e frustração apontam para a confusão estabelecida na troca de simulacros entre Della e Jim. Cada um dos cônjuges aprofunda o hiato fiduciário, ou seja, fica demonstrada a vulnerabilidade das trocas sociais, no caso, na relação amorosa. Por meio desses recursos, O. Henry recupera figuras bíblicas do Novo Testamento para deslocá-las da cena eufórica fundante. Recuperamos, a seguir, três versículos da passagem bíblica na qual a visita dos Reis Magos ao menino Jesus se realiza. Desse modo, podemos cotejar as estruturas de troca de presentes tal como descritas no capítulo bíblico e no conto de O. Henry:

Os Magos do oriente vêm adorar Jesus

Mt. 2, 9-11

9 A tais palavras do rei, partiram. E eis que a estrela, que havia visto no Oriente, os precedia, até que chegou e ficou parada sobre o lugar, onde se achava o menino.

10 Ao verem o astro, exultaram com grandes transportes de alegria. 11 Entrando na casa, viram o menino com Maria, sua mãe, e, prostrando-se, o adoraram; a seguir, abrindo seus tesouros, ofereceram-lhe de presente ouro, incenso e mirra. (BÍBLIA SAGRADA, 2002, p. 1240)

No texto de O. Henry, no lugar da euforia homologada à esperança no instante da visita dos Reis Magos para o Rei que nasce, temos a disforia homologada ao desvelamento da falta: o presenteado não poderá usar o presente. Eliminada a iminência da fruição, compatível com as paixões da completude e o cumprimento do contrato fiduciário, resta a relação cotidiana entre o casal de amantes, permeada pela ausência: ausência de conhecimento sobre possíveis performances recíprocas (nem Della nem Jim puderam ou souberam prever ações recíprocas). O símbolo cristão, representado no conto por "Feliz Natal”, é mais do que consumismo capitalista, ele é ironizado pelo Discurso. A enunciação, então, provoca o leitor: não existe "Feliz Natal". Os atores do enunciado se configuram assim pelo traço da ingenuidade: /não saber/, /não crer não saber/ das contradições do mundo.

O final do conto revela, portanto, a racionalidade dos sujeitos que percebem por meio de uma diminuição da emoção e com ceticismo existencial o fim da utopia, verificada em $O$ presente dos magos pela questão: “Que tal se você fritasse as costeletas agora?”. Esse desvelamento final, dado pela constatação dos desdobramentos causados por uma falta e pelas paixões decorrentes dela, 
demonstra que há uma proposição do sujeito no mundo como um ser em falta, isto é, a ausência da possibilidade de ser feliz. O ser humano quer, deve, mas não sabe, logo, não pode ser feliz.

Dentre todos os temas disponibilizados pelo texto, enfatizamos aqueles que estão relacionados à impossibilidade da completude na constituição da natureza humana. $\mathrm{O}$ tema da incompletude é figurativizado por meio dos atores do enunciado: marido e mulher que se movimentam em um espaço discursivizado como o espaço do alhures e como atores dados segundo o ele. Ao longo do conto, as conquistas e as perdas de objetos comprovam esse tema. Ao passo que um objeto é conseguido um outro é perdido. No fim do texto, esse tema fica mais evidente, uma vez que ao dar os presentes nenhum dos dois podia gozar de seus objetos de valor, já que uma falta havia sido instalada, não permitindo que os objetos fossem utilizados. Desse modo, os atores apresentamse sempre em falta, o que permite ao discurso a construção de um mundo em que a falta é determinante na trajetória do homem. 


\section{CAPÍTULO III - O Henry: um éthos e um páthos}

\subsection{Estilo e Éthos}

Tendo, pois, desconstruído pela análise o texto de O. Henry, a fim de deixar à mostra uma estrutura que permite observar como o sentido foi erigido, resta-nos, nesse momento, encontrar elementos comuns decomposição em outros contos do autor, os quais entrarão como argumento comprobatório das depreensões feitas paraa construção do sentido de $O$ presente dos magos.

A partir dos modos e formas de organização de um unus, buscaremos confirmar como esse conto se articula a um totus, isto é, como a totalidade recortada cria esse unus. Tais "formas de organização" da unidade, relacionadas a formas de organização similares da totalidade, confirmam um estilo ao recuperar, pois a relação da parte no todo. Nesse sentido, Discini (2003, p. 31) afirma que "ao falar em estilo, falamos em unidade e em totalidade; unidade porque há um sentido único, ou um efeito de individuação; totalidade, porque há um conjunto de discursos, pressuposto à unidade". Unidade e totalidade formam o eixo a partir do qual a individuação, base do estilo, desponta e possibilita a depreensão de um éthos, constituinte do efeito de sujeito de uma totalidade.

O unus pressupõe o totus, o "bloco inteiro", a totalidade integral, a qual "destaca a absorção dos indivíduos isolados numa massa indivisível”. Estilo é, então, totalidade, enquanto unidade integral (unus) e enquanto totalidade integral (totus), sendo que um termo pressupõe outro, numa relação de interdependência. É o recorte do leitor que decide o que é considerado unus ou totus (DISCINI, 2003, p. $34)$.

Nesse esteira, pretendemos verificar as relações que as organizações sintáticas e semânticas do conto O presente dos magos (unus) entretêm com outros contos do autor (totus) para identificar estruturas recorrentes de um conjunto de discursos e, por conseguinte, um efeito de estilo, 
determinado por uma constância nos procedimentos de construção do sentido. Tal efeito de estilo remete obrigatoriamente a um efeito de sujeito, que, por sua vez, aponta para um actante-sujeito da enunciação, isto é, ao ator da enunciação, em se tratando de uma totalidade de discursos. Em relação ao ator da enunciação, Discini (2003, p. 39) vai dizer que

\begin{abstract}
O enunciador do estilo, produto da reunião das propriedades assinaladas, pode ser visto como o grande enunciador, construído por meio do efeito de individuação. A totalidade de discursos constrói esse efeito de individuação, fundamentado-o num efeito de perspectiva sobre o mundo, o que indica crenças, transformadas em valores. Esse efeito de individuação, salientamos, emerge da recorrência do uso.
\end{abstract}

Do estilo pode-se reconstruir umcorpo, uma voz e um caráter do sujeito enunciador, ou seja, o éthos do contista e, emparelhado a ele e como reflexo e refração dele o páthos do leitor dos contos. Encaminhamo-nos, então, para a afirmação de que as recorrências na estruturação dos textos de O. Henry configuramum éthos depreendido pelo modo recorrente de dizer.

\begin{abstract}
Descrever um estilo é (re)construí-lo. Para tanto, (re)construímos o ator da enunciação, esse sujeito cuja figura emerge como corpo, como caráter de uma totalidade enunciada. Por isso, o estilo é um efeito de sentido, uma construção do discurso. O efeito de estilo pressupõe, concretizada nas figuras da espacialidade, temporalidade e actorialidade uma sistematização (DISCINI, 2003, p. 59).
\end{abstract}

Em busca do estilo de O. Henry, tomaremos por base, então, a permanência de escolhas na construção do sentido, para que possamos confirmar um corpo, um caráter e uma voz de uma unidade estilística. Assim, conduzimo-nos a examinar uma cenografia específica para o ator da enunciação dos contos. É a partir da cenografia (situação de enunciação), portanto, que serão gerados o éthos do enunciador entendido como a imagem do autor e o páthos do enunciatário 
entendido, por sua vez, como a imagem do leitor. O éthos, reafirmamos aqui, é depreendido pelo caráter, corpo e tom de voz do enunciador eé ao papel primordial desempenhado pelavoz do enunciador que conferimos o poder de exprimir a sua interioridade, com a qual dizemos que há um envolvimento do co-enunciador fiscamente.

Refletindo, ainda, sobre a previsibilidade de imagens do enunciatário nos discursos, podemos pensar que, se de acordo com o "foco de coordenadas" que compõem a cenografia, o eu sempre se dirige a um tu, um tu já é previsto pelo produtor. Nesse caso, um tipo de co-enunciador que se relaciona ao éthos de um discurso dado é sempre previsto pelo actante da enunciação como um feixe de expectativas dado pelo próprio texto. A respeito dessa questão, Fiorin (2004b, p. 135) afirma que

Com efeito, a imagem do enunciatário constitui uma das coerções discursivas a que obedece o enunciador: não é a mesma coisa produzir um texto para um especialista numa dada disciplina ou para um leigo; para uma criança ou para um adulto. O enunciatário é também uma construção do discurso.

Nesse sentido, cada discurso constrói seu público que influencia, por sua vez, nas escolhas discursivas para a produção do texto. O leitor é, dessa forma, uma figura virtual, ou seja, um destinatário implícito para o qual o discurso se dirige devendo respeitar ascoerções do gêneroe a enunciação particular instituídas pela obra. O público/leitor pretendido pelo autor é aquele que é tido em mente, como um efeito de sentido dado nos próprios textos. Dessa maneira, temos uma compatibilidade entre essas duas instâncias que emergem no texto, ou seja, há uma convergência entre éthos e páthos, pois o leitor já é o pressuposto do texto e a obra já organiza e dirige a leitura.

Como ilustração de previsibilidade de co-enunciadores, um exemplo de Maingueneau (2005a, p. 91) serve a nossos propósitos:

No discurso humanista devoto, por exemplo, o enunciador se dá como integrado em uma "Ordem": é membro de uma comunidade religiosa reconhecida, bispo, mestre-escola... e dirige-se a destinatários também inscritos em 'Ordens' 
socialmente bem caracterizadas (enquanto pais de famílias, magistrados, donas de casa, etc...

O páthos projetado pelo escritor no interior do discurso diz respeito, dessa forma, à imagem do receptor ideal, capaz de concretizar os sentidos pelos percursos de leitura propostos pelo texto, visto como unidade em análise ou totalidade pressupostos. O leitor, cuja previsibilidade está assentada no texto, compartilha com o enunciador "mundos que ele torna sensíveis por seu próprio processo de enunciação" (MAINGUENEAU, 2005b, p. 87), isto é, há incorporação, já que o coenunciador se relaciona ao éthos de um dado discurso.

Do conjunto de textos de O. Henry, fizemos um recorte selecionando outros três contos para examinar supostas recorrências na obra do autor. Esses textos ${ }^{14}$ propiciam, então, operar com possíveis generalizações em relação a um modo próprio de construção do sentido que perpassa toda a composição do escritor. Estabelecemos, dessa forma, como critério de busca de recorrências pontos advindos da análise de $O$ presente dos magos, pois as considerações feitas neste item do trabalho seguem o movimento que parte do unus em direção ao totus, na confirmação da participação da unidade na totalidade.

A análise que apresentamos do conto permite estabelecer, então, um pilar analítico que possibilita observar o uso de recursos recorrentes em outros textos de O. Henry, pois como estamos tratando de éthos e páthos, torna-se necessário calçar nosso exame do conto $O$ presente dos magos em subsídios analíticos advindos de outras produções literárias do mesmo autor, para que possamos formar uma totalidade discursiva e observar recorrências no modo de dizer.

É nas recorrências existentes na totalidade de discursos, que o éthos e o páthos podem ser reconstruídos, partindo da profundidade, por meio da articulação da categoria mínima de sentido, até as estruturas mais superficiais como a recorrências temático-figurativas. Assim, esse modo próprio de construção textual deve manifestar, por meio das recorrências do dito, um estilo, uma voz, um tom de voz, um caráter, um corpo; corpo este "que enunciador e enunciatário partilham, enquanto construções e reconhecimento e que é construído para o enunciador ou fiador da enunciação como o éthos que toma corpo e, para o enunciatário, ou co-enunciador, como a incorporação desse corpo" (DISCINI, 2003, p. 58). Nossas discussões orientam-se também pelas diretrizes propostas por Fiorin (2004b, p. 125):

14 Os outros três contos de O. Henry constam dos anexos nesta dissertação. 
Onde se encontram, na materialidade discursiva da totalidade, as marcas do éthos do enunciador? Dentro dessa totalidade, procuram-se recorrências em qualquer elemento composicional do discurso ou do texto: na escolha do assunto, na construção das personagens, nos gêneros escolhidos, no nível da linguagem usado, no ritmo, na figurativização, na escolha dos temas, nas isotopias etc.

É, então, em busca das recorrências de um modo próprio de dizer que, nossas análises vão encaminhar-se, obedecendo à divisão em níveis do Percurso Gerativo do Sentido. Buscaremos, assim, semelhanças na maneira de estruturar o nível fundamental dos outros contos, averiguando a escolha de termos categoriais mínimos de sentido, bem como o investimento tímico dado a eles. Mais ainda, no nível narrativo, examinaremos as similaridades na arquitetura dos percursos narrativos dos actantes-sujeitos e seus movimentos de disjunção em busca de conjunção. E, por fim, no nível discursivo, o modo como o enunciador recorre às debreagens para instalar um narrador pontual, uma maneira própria de trabalhar com a espacialização e temporalização, e de tematizar e figurativizar seus contos.

\subsection{Em busca do éthos e do páthos em O. Henry}

Para poder, então, depreender o éthos e o páthos em O. Henry, iremos nos pautar, fundamentalmente, em mais três contos do escritor, além de $O$ presente dos magos, já analisado por nós. O primeiro deles intitula-se $O$ quarto alugado. Esse conto descreve o percurso de um homem que tenta desesperadamente encontrar sua amada. Depois de incessantes buscas pela mulher desaparecida, o rapaz, não suportando a dor da falta por não ter conseguido encontrá-la, decide se suicidar.

Um outro conto, a partir do qual buscaremos recorrências, chama-se The Brief Debut of Tildy $^{15}$. A narrativa mostra uma garçonete que nunca conseguiu encontrar um namorado. Subitamente, um homem a beija na lanchonete onde trabalhava e ela pensa ter, finalmente, se deparado com um grande amor. No entanto, o final do conto revela que o homem estava alterado pela bebida, pede desculpas à garçonete pelo o que havia feito e vai embora. A moça retorna ao estado de solidão atestado no início do texto.

15 A breve estréia de Tildy (Tradução nossa). 
O terceiro texto, a ser colocado em cotejo, denomina-se A Service of Love ${ }^{16}$. Nesse conto, um casal em conjunção com o dinheiro passa a entrar em disjunção com ele e tem de aprender a viver sem as mordomias com as quais estava acostumado. Da posse a despossessão, a narrativa trata de sacrifícios feitos pelo casal de amantes. A esposa, estudante de piano, por exemplo, vê-se forçada a trabalhar em uma lavanderia para poder proporcionar ao casal uma sobrevivência mínima.

\subsubsection{Nível fundamental e narrativo}

Nos contos selecionados, temos dois tipos de movimentos de articulação no nível profundo e no nível narrativo: um que institui o final em disjunção e outro que institui um final em conjunção. Esses contos reforçam, portanto, os termos mínimos encontrados em $O$ presente dos magos. Apresenta-se, dessa maneira, uma tensão entre conjunções e disjunções no nível narrativo que configuram a gratuidade e o utilitarismo, valores do capitalismo, do nível profundo. Em $O$ quarto alugado, por exemplo, tal articulação mínima é tão evidente que a disjunção total do objetovalor culmina em suicídio. Temos, claramente, um final em disjunção em que a ausência impera. Impulsiona-se a presença em direção à ausência, o que estrutura o quadrado semiótico desse conto.

\footnotetext{
Não, sempre não. Cinco meses de interrogatórios incessantes e a inevitável negativa. Tempo perdido durante o dia a questionar empresários, agentes, escolas e companhias; e durante a noite, a perscrutar a assistência dos teatros, desde os de primeira ordem até music-halls tão sórdidos que temia encontrar neles, aquela por quem tanto suspirava. Ele que tanto a amara, tenta reencontrá-la (O. HENRY, 1988, p. 87).
}

Explicita-se o percurso de insucessos na busca de um sujeito do querer, "Cinco meses de interrogatórios incessantes e a inevitável negativa. Tempo perdido durante o dia a questionar empresários, agentes, escolas e companhias; e durante a noite, a perscrutar a assistência dos teatros"; e a falta surge sem reparação - "Não, sempre não”. A impossibilidade de encontrá-la e o suicídio subseqüente atestam um ser humano que não sabe, não quer e não pode conviver com a

16 Um serviço de amor (Tradução nossa). 
falta. A lembrança da amada reforça paixões da disjunção e tensão pelo querer-ser, crer-não-ser e saber-poder-não-ser. A isotopia da infelicidade é, dessa forma, criada por esse núcleo de paixão.

O rapaz agradeceu e voltou desanimado para o quarto. O aposento estava morto. Volatilizara a essência que lhe dera vida. Fora-se o perfume de resedá. Em seu lugar, havia agora o antigo cheiro rançoso de móveis mofados, de atmosfera confinada.

Fugira-lhe a esperança, e, com ela, a fé. Ele sentou-se e ficou a olhar o gás amarelo que sibilava. Logo se dirigiu para a cama e começou a rasgar os lençóis. Com a lâmina do canivete, introduziu-as apertadamente, em todas as fendas em volta das janelas e da porta. Quando tudo estava bem calafetado, desligou o gás, escancarou-o novamente, e estendeu-se gratamente no leito (O. HENRY, 1988, p. 90).

O suicídio, firmado nas bases de uma quebra na esperança pelo fim de um querer, atesta um estado tenso-disfórico pela impossibilidade da aquisição do objeto (amada) e, por conseguinte, da impossibilidade da completude dada segundo uma conjunção total. Resta a falta levada até as últimas conseqüências a morte, termo negativo que compõe o eixo semântico da existência.

Em The Brief Debut of Tildy, observamos mais um exemplo de conto de final em disjunção. Uma garçonete que nuncahavia tido um namorado vive uma vida solitária e em falta.

In the steaming, chattering cabbage-scent Bogle's there was almost a heart tragedy. Tildy with the blunt nose, the hay-coloured hair, the freckled skin, the bag-o'-meal figure, had never had an admirer. Not a man followed her with his eyes when she went to and fro in the restaurant save now and then when they glared with the beast hunger for food. None of them bantered her gaily to conquettish interchanges of wit. None of them loudly 'jollied' her of mornings as they did Aileen, accusing her, when the eggs were slow in coming [...]. No one had ever given her a turquoise ring or invited her upon a voyage to mysterious distant 'Parsifal'. (O. HENRY, 1995, p. 82). ${ }^{17}$

17 No ruidoso Bogle's, com seu vaporoso cheiro de repolho, havia quase uma tragédia do coração. Tildy com seu nariz obtuso, o cabelo cor de feno, a pele sardenta, a figura de saco de comida, nunca tinha tido um admirador. Nunca nenhum homem jamais a seguiu com seus olhos quando ela ia para lá e para cá no restaurante, salvo às vezes quando eles olhavam fixamente loucos por comida. Nenhum deles brincava com ela alegremente para 
A constante enumeração negativa dada no enunciado para a falta (never - nunca, not a nem um, none of - nenhum, no one - nenhum), confirma no nível fundamental a escolha do termo categorial da ausência. Determinam-se, inicialmente, valores disfóricos para a constituição do ser do sujeito e direciona-se o destino (fazer) narrativo do actante a uma possível conjunção.

Nessa trajetória primeira de ausência que beira a inexistência, um certo dia, Tildy é beijada de surpresa por um dos fregueses do restaurante para o qual trabalhava. Arrebatada por um amor súbito, a garçonete entra em conjunção com um sentimento que jamais possuíra. Vemos, dessa forma, o movimentar dos termos mínimos de articulação de sentido do conto. Temos a passagem da ausência à presença e, conseqüentemente, de um estado de disjunção a um estado de conjunção com os valores do amor.

One day when Mr. Seeders came in to dinner he had been drinking beer. There were only two or three customers in the restaurant. When Mr. Seeders had finished his weakfish he got up, put his arm around Tildy's waist, kissed her loudly and impudently, walked out upon the street, snapped his fingers in the direction of the laundry (O. HENRY, 1995, p. 83). ${ }^{18}$

A conjunção com o objeto visado euforiza a presença e permite aflorar paixões da satisfação e alegria pela reparação da falta. Institui-se um sujeito em posse de valores cuja base está assentada na modalidade do querer, já que está de posse de um objeto de desejo. O sentimento de felicidade/alegria é erigido ainda pela sanção positiva que Tildy recebera de Mr. Seeders: "man had found her waist achievable and desirable" (O. HENRY, 1995, p. 83) ${ }^{19}$, pois como já foi dito, ela nunca havia sido reconhecida por nenhum homem. Tildy enquanto objeto, torna-se desejável a Mr. Seeders, o desejável na esteira do positivo e do querer possuir. O reconhecimento positivo dado a Tildy, desperta ainda uma paixão fiduciária na crença de que o homem gosta dela, “And Tildy’s heart swelled in her bosom, for she saw at last the towers of Romance rise above the horizon of the gray

conquistar trocas de bom senso. Nenhum deles ruidosamente a 'saudava'pelas manhãs como eles faziam com Aileen, acusando-a, quando os ovos estavam demorando a chegar [...] Ninguém nunca havia lhe dado um anel de turquesa ou a convidado a uma viagem para o misterioso e distante 'Parsifal' (Tradução nossa).

${ }^{18}$ Um dia quando Mr. Seeders veio para o jantar ele começou a beber cerveja. Havia somente dois ou três clientes no restaurante. Quando Mr. Seeders terminou seu peixe ele se levantou, colocou seu braço ao redor da cintura de Tildy, beijou-a ruidosamente e descaradamente, caminhou em direção à rua, estalou seus dedos em direção à lavanderia. (Tradução nossa).

19 Um homem achou sua cintura possível de ser conquistada e desejável (Tradução nossa). 
plain in which she had for so long traveled" (O HENRY, 1995, p. 84) ${ }^{20}$, já que uma crença no outro é estabelecida, isto é, uma relação de confiança. Nesse caso, há um contrato imaginário, em que Tildy pensa poder contar com Mr. Seeders para realizar suas esperanças.

No fim do conto, no entanto, movimentam-se, mais uma vez, os termos da estrutura fundamental, instituindo um retorno à disjunção.

'Miss Tildy", said he, 'I want to apologize for what I done the other evenin'. Tell you the truth, I was pretty well tanked up or I wouldn't of done it. I wouldn't do no lady that a-way when I was sober. So I hope, Miss Tildy, you'll accept my “pology, and believe that I wouldn't of done it If I'd known what I was doin'and hadn't of been drunk'.

With this handsome plea Mr. Seeders backed away, and departed, feeling that reparation had been made.

But behind the convenient screen Tildy had thrown herself flat upon a table among the butter chips and the coffee cups, and was sobbing her heart out - out and back again to the grey plain wherein travel they with blunt noses and haycoloured hair (O. HENRY, 1995, p. 85). ${ }^{21}$

A expressão - "back again (de volta)" - reforça o retorno ao estado inicial do sujeito, um sujeito em falta, em disjunção, em ausência, enfim. Paixões da tristeza e decepção, fundadas pela quebra do simulacro construído por Tildy, revelam o rompimento da relação fiduciária - de confiança. Dessa forma, não há um direcionamento à liquidação da falta e a garçonete volta a ficar sozinha: "and back again to the grey plain wherein travel they with blunt noses and hay-coloured hair" (O. HENRY, 1995, p. 85 - grifo nosso).

Ainda, em A Service of Love, verificamos a mesma recorrência no modo de estruturar o nível fundamental e narrativo: o início do conto demonstra a conjunção com valores materiais. A posse euforiza a "presença" que afirma a completude dos sujeitos.

\footnotetext{
${ }^{20}$ E o coração de Tildy inchou em seu peito, pois, ela viu, até que enfim, as torres do Romance elevarem-se na linha do horizonte da planície cinza na qual ela havia viajado por tanto tempo (tradução nossa).

${ }^{21}$ Senhorita Tildy', disse ele, 'Eu quero me desculpar pelo o que eu fiz naquela noite'. Para dizer a verdade, Eu estava bastante bêbado ou então eu não teria feito aquilo. E não faria a nenhuma senhora aquilo se eu estivesse sóbrio. Então eu espero, senhorita Tildy, que você aceite minhas desculpas, e acredite que eu não teria feito aquilo se eu soubesse o que eu estava fazendo e se eu não estive bêbado'. Com esse belo apelo o Sr. Seeders virou-se, e partiu, sentindo que a reparação tinha sido feita.

Mas atrás da tela conveniente Tildy tinha se atirado em uma mesa entre as batatas amanteigadas e as xícaras de café, e estava soluçando seu coração para fora - fora e de volta à planície cinza por onde havia viajado com o nariz rude e o cabelo cor de feno (tradução nossa).
} 
But the best in my opinion was the home life in the little flat- the ardent, voluble chats after the day's study; the cozy dinners and fresh, light breakfasts; [...] stuffed olives and cheese sandwiches at 11 p.m. (O. HENRY, 1995, p. 22). ${ }^{22}$

A ausência, verificada pela introdução de uma disjunção que persiste até o fim do conto, mais uma vez, institui sujeitos em falta: "everything going out and nothing coming in" (O. HENRY, 1995, p. 22) 23 $^{23}$ "money was lacking to pay Mr. Magister and Herr Rosenstock their prices" (O. HENRY, 1995, p. 22). ${ }^{24}$ Ainda, o tema do sacrifício, perpassado pela dificuldade financeira, para a liquidação da falta se apresenta novamentecomo constituinte de mais um texto de O. Henry.

Um processo gradual de disjunção é estabelecido e a despossessão com o objeto-valor dinheiro é a propulsora dos desenvolvimentos narrativos. O casal, vendo-se privar dos valores aos quais estava acostumado, decide ir em busca do objeto desejado. Temos um emparelhamento de programas narrativos, assim como em $O$ presente dos magos, em que cada um dos sujeitos desempenha um percurso semelhante. Della e Jim executam o programa narrativo da venda e da compra, Joe e Delia executam o do trabalho, pois tiveram que trabalhar para suprir as necessidades da casa.

Tanto em um como em outro conto, o percurso é desenvolvido secretamente. A sanção positiva, dada segundo o sacrifício feito, tende a reconhecer positivamente os atos dos sujeitos do enunciado. Em ambos os contos, as ações pautadas no deslocamento narrativo são euforizadas, mesmo que a falta persista, pois o julgamento positivo reside justamente no fazer do sujeito. Em relação a esse tipo de sanção que recai sobre o fazer embebido pelo sacrifício, recuperamos mais um trecho de A Service of Love:

What have you been doing for the last two weeks, Dele? He asked.

I couldn't get any pupils, she confessed. And I couldn't bear to have you give up your lessons; and I got a place ironing shirts in that big Twentyfourth street laundry. And I think I did very well to make up both General Pinkney and Clementina, don't you, Joe? And

\footnotetext{
22 Mas, o melhor em minha opinião, era a vida do lar no pequeno apartamento - as ardentes e volumosas conversas depois do dia de estudo, os jantares aconchegantes e o café da manhã sempre leve e fresco; [...] azeitonas recheadas e sanduíches de queijo às 11 da noite (Tradução nossa).

23 Tudo saindo e nada entrando (Tradução nossa).

24 O dinheiro começava a faltar para pagar o Sr. Magister e Herr Rosenstock seus preços (Tradução nossa).
} 
when a girl in the laundry set down a hot iron on my hand this afternoon I was all the way home making up that story about the Welsh rabbit. You're not angry, are you, Joe? And if I hadn't got the work you mightn't have sold your sketches to that man from Peoria (O.

HENRY, 1995, p. 25). ${ }^{25}$

Os exemplos de contos que trabalham com esse tipo de transformação básica são inúmeros. Tivemos a pretensão aqui de demonstrar apenas alguns para elucidar uma recorrência na construção do sentido em O. Henry, isto é, contos que articulam os termos fundamentais, a partir da seguinte estrutura: da ausência à presença e da presença à ausência. Os finais são sempre em disjunção e o sujeito sempre em falta. Essa falta ocupa uma posição essencial no desenvolvimento narrativo da totalidade, uma vez que se apresenta como uma peça motriz de constituição textual. Como afirmam Greimas e Courtés ([1983],p. 181)

No esquema narrativo canônico, derivado de Propp, a falta é a expressão figurativa da disjunção inicial entre sujeito e objeto da busca: a transformação que opera sua conjunção (ou a realização) desempenha um papel de pivô narrativo (que permite passar de um estado de carência a sua liquidação) e corresponde à prova decisiva (ou performance). Assim, vê-se que a falta não é propriamente uma função, ms um estado que resulta, em verdade, de uma operação prévia de negação (situada ao nível profundo).

No entanto, mesmo que em outros contos a conjunção seja instituída para o final do texto, temos que salientar que a disjunção toma grande parte dos percursos narrativos dos sujeitos: "uma falta compensada, mas sempre recriada" (DISCINI, 2003, p. 47).

Lembramos que o objetivo do cotejo com outros textos do autor é a depreensão da recorrência de um modo de dizer que remete a um modo de ser. O que importa, então, averiguar aqui é o uso recorrente do mecanismo narrativo de instauração de uma falta e demonstrar como a

25 O que você tem feito nessas duas últimas semanas, Dele? Ele perguntou.

Eu não consegui nenhum aluno, ela confessou. E eu não podia suportar a idéia de você deixar suas aulas; e eu consegui um posto para passar camisas naquela grande lavanderia da Vigésima-quarta avenida. E eu acho que eu fiz bem em inventar sobre o General Pinkney e Clementina, não é, Joe? E quando uma garota na lavanderia derrubou aquele ferro quente em minha mão esta tarde, eu estive o caminho todo de volta para casa inventando essa história sobre o coelho de Gales. Você não está bravo, está Joe? E se eu não tivesse conseguido o trabalho você não teria vendido seus esquetes para aquele homem de Peoria (Tradução nossa). 
ausência e a disjunção constituem o pivô narrativo em O. Henry. Para reforçar nossas constatações, aproveitamos um excerto do conto The Pendulum ${ }^{26}$, que, apesar de não figurar de nosso corpus, deve ser aproveitado para explicitar o papel da falta nos trabalhos de O. Henry. Um casal que nunca havia se separado, vê-se agora longe. A esposa de John teve que ir cuidar de sua mãe doente e ele sente a dor da separação momentânea: "Never during their two years of matrimony had he and Katy been separated for a night. John read the note over and over in a dumbfounded way. Here was a break in a routine that had never varied, and it left him dazed" (O. HENRY, 1995, p. 124). ${ }^{27}$

O rompimento na rotina conjugal faz surgir paixões de tristeza e melancolia ligadas ao prolongamento durativo da falta da esposa. Opera-se a disjunção e com ela o sofrimento do sujeito:

Everything in the room spoke of a loss, of an essence gone, of its soul and life departed. John Perkins stood among the dead remains with a queer feeling of desolation in his heart" 28 ,"he had never thought what existence would be without Katy. She had become so thoroughly annealed into his life that she was like the air he breathed--necessary but scarcely noticed. Now, without warning, she was gone, vanished, as completely absent as if she had never existed. (O. HENRY, 1995 , p. 124$)^{29}$

Vemos, assim, um sujeito modalizado por um querer intenso, a partir do qual paixões da falta se apresentam no enlace narrativo. Notamos, assim, em O. Henry, paixões humanas surgidas pelo sofrimento que pressupõem modalizações do querer determinadas pela falta: um sujeito patemizado pela insatisfação que culmina em resignação. Para explicitar a recorrência da paixão da resignação, tomemos como exemplo o conto O quarto alugado. Sem mais esperanças de encontrar a mulher que tanto procurava, o rapaz só pode aceitar: "O rapaz agradeceu e voltou desanimado para o quarto". (O. HENRY, 1988, p. 90)

Verificamos, até o momento, que todas as mudanças nos estados narrativos dos actantes do enunciado dos contos, vislumbram uma quebra na rotina e, por isso mesmo, na previsibilidade 26 O pêndulo (Tradução nossa).

27 Nunca durante seus dois anos de matrimônio, tinham ele e Katy se separado por uma noite. John leu o bilhete várias vezes pasmo. Aqui estava uma quebra na rotina que nunca variava, e isso o deixava atordoado (Tradução

28 npssa)

quarto falava de uma perda, de uma essência que se foi, de sua alma e vida que partiram, John Perkins estava parado no meio dos restos mortos com um sentimento estranho de desolação no coração (Tradução nossa).

29 Ele nunca imaginou sua existência sem a Katy. Ela se tornou tão completamente ligada a sua vida que ela era como o ar que ele respirava - necessária, mas raramente notada. Agora, sem aviso, ela se foi, desapareceu, tão completamente ausente como se ela nunca tivesse existido (Tradução nossa). 
das ações. Cria-se uma fratura que põe em cena sujeitos de espera com a conjunção total com os objetos de valor visados. A cisão, pela introdução do descontínuo na continuidade sintagmática do discurso, permanece enquanto parte da vida do sujeito, pois a experiência dramática do descontínuo nunca se dilui completamente. Essa falta, que sempre volta nos textos de O. Henry, torna visível uma circularidade que pressupõe a própria pulsação constitutiva do ser que se funda em ausências e presenças.

Demonstra-se, com isso, a tendência contínua à conjunção dada pelo querer dos seres humanos. Esse é o modo de existência dos sujeitos em O. Henry, sujeitos que têm como identidade definida passar por momentos de tristeza, angústia e insatisfação, o que reforça o status de vulnerabilidade humana. Tal é o mundo previsível construído pela totalidade para os sujeitos, uma exacerbação da falta nos contos, uma falta dolorosa e inevitável como parte da figura do homem, isto é, uma existência atravessada pela idéia da ruptura amorosa, da ausência, da ferida, da tristeza, da cisão.

Dessa forma, O. Henry alerta para a descontinuidade, tematizada pela despossessão, ao qual todos os seres humanos passam na vida; despossessão esta, material ou sentimental. Direcionase, assim, o leitor a ver na descontinuidade valores que transcendem a cotidianeidade. As disjunções, tidas como ápice narrativo ao demonstrarem a irreparável lacuna que perdura, fazem com que o discurso nos aproxime da ausência e sugere o gosto do incômodo e do desconforto suscitados pelos textos. A predileção por paixões da falta, com seus estados durativo-contínuo acentuados pela distância, exibe um sujeito que enuncia sempre o querer ser daqueles que não são. Uma "oscilação passional", dada segundo as disjunções e as conjunções, aparece, então, como uma marca na obra do autor: de alegrias sublimes pela aquisição de objetos-valor a tristezas profundas pela perda dos mesmos.

A ausência, recorrente nos contos de O. Henry, expõe, dessa maneira, os estados existenciais dos sujeitos do enunciado. Estados estes de plenitude que se dirigem à vacuidade dada segundo disjunções operadas nos percursos narrativos. Coloca-se em jogo, a passagem de estados de densidade existencial, pois os sujeitos ao perderem uma condição de conjunção anterior se deparam com a impossibilidade ou a dificuldade de abraçar qualquer projeto novo de reconquista de seus objetos. Assim, os sujeitos nos contos de O. Henry sempre se apresentam, em um ou outro ponto da narrativa, em estado de vacuidade ${ }^{30}$ pela perda ou pela impossibilidade de conjunção com objetos de desejo. Efetivam-se, dessa forma, papéis actanciais que revelam papéis temáticos para os atores no nível discursivo.

30 Termo empregado por Luiz Tatit (2001, p. 141). 
As análises efetuadas, tendo em vista apenas o nível fundamental e narrativo dos contos até o momento, tiveram a pretensão de propor uma fórmula sintáxica genérica das articulações primárias e seus revestimentos em ações a partir do início, meio e fim dos textos. A regularidade procurada reside, assim, no encadeamento orientado dos acontecimentos que culminam em uma intensificação da disjunção em um movimento de avultamento da falta. Essa fórmula elementar de tratar a narrativa tem, ao nosso ver, um ponto de intensificação que perpassa todos os contos do autor: a ausência, a falta, a disjunção.

Averiguamos, por entre a tessitura dos contos, então, uma avaliação crítica do ator da enunciação em relação aos estados de conjunção e disjunção aos quais os seres humanos estão fadados. Disjunções dadas segundo as incompletudes e conjunções dadas pelas completudes que aparecem para centralizar a tensão existente nas relações entre sujeitos. Estamos diante de opções feitas por um sujeito para engendrar uma estratégia narrativa a partir da qual o sentido narrativo resulta e remete, em última instância, ao sujeito da enunciação.

\subsubsection{Nível discursivo}

Encontrar recorrências a partir dos sub-componentes do nível discursivo é averiguar aproximações entre contos da obra de O. Henry por similaridades nos elementos de actorialização, temporalização, espacialização, tematização e figurativização.

No que concerne à busca de recorrências em semântica discursiva, isto é, temas e figuras, iremos nos apoiar nas discussões feitas por Barros sobre configuração discursiva, a fim de encontrar percursos figurativos e temáticos invariantes na obra de O. Henry. Dessa maneira, resgatando sempre as estruturas de $O$ presente dos magos, tentaremos observar uma invariância figurativa e temática que costura os textos do autor. Barros (2001, p. 120) define configuração discursiva como "uma espécie de 'lexema do discurso', que subsume vários percursos figurativos e temáticos, além dos narrativos, e conta com algumas figuras invariantes”. A configuração discursiva é identificada ainda por figuras que permanecem, mas também pode apresentar "uma variação na configuração, seja figurativa, temática ou narrativa" (BARROS, 2001, p. 121).

Em O. Henry, um primeiro percurso figurativo que atravessa seus contos é aquele ligado à figura do dinheiro que constitui, por sua vez, um núcleo figurativo comum a seus textos. Ainda, Discini (2003, p. 65) nos mostra a importância das configurações discursivas na depreensão do estilo: "Propomos, para a análise de um estilo, que esse estoque de configurações discursivas seja 
visto como uma configuração interdiscursiva, cujos núcleos figurativos e temáticos apontam para a reconstrução do significado da totalidade". Por meio da observação da recorrência desses núcleos mencionados pela autora, podemos, enfim, notar valores sociais e individuais afirmados ou negados pelo enunciador.Tais valores se apóiam, portanto, nos universais presença vs ausência atribuídos como organização mínima para seus contos.

Examinemos, então, o núcleo figurativo constituído pela figura invariante do dinheiro em dois contos. Em $O$ presente dos magos, como já analisado, a figura do dinheiro compõe fundamentalmente o percurso narrativo de busca e estabelece o tema socioeconômico da despossessão financeira. No conto A Service of Love, temos o mesmo núcleo figurativo recoberto pelo tema da queda dos recursos econômicos: "They were mighty happy as long as their money lasted" ${ }^{31}$ (O. HENRY, 1995, p. 22) A privação com tal objeto força os actantes a ações de aquisição: "For two or three days she went out canvassing for pupils". ${ }^{32}$ (O. HENRY, 1995, p. 22) Reforçamos, ainda, que o dinheiro concretiza um percurso temático pautado pela desapropriação/privação econômica, constituindo um núcleo temático da necessidade financeira.

Averiguamos, assim, um modo repetido de usar figuras e temas circunscrito fundamentalmente às relações conjugais permeadas por "amor" e "dinheiro". Notemos como se constrói a totalidade pelo desenvolvimento de núcleos temáticos e figurativos envolvidos por uma axiologização da falta material e sentimental e as conseqüências decorrentes dela. Ritualiza-se uma performance dos atores que emparelhada conto a conto representa uma coletividade pela existência do papel de um ator em ausência.

A espacialidade na obra de O. Henry merece também algum destaque. Recorrente é o uso da categoria da interioridade e o modo dos atores de ocupar o espaço enunciado. Em seus contos, tal categoria aparece figurativizada como a habitação ou como o local de trabalho dos atores do enunciado. Lugares, na maioria das vezes, disforizados pelo tipo de figuratividade que iconiza negativamente o ambiente no qual se encontram os sujeitos da narrativa. As figuras que revestem o termo da interioridade estão sempre ligadas à falta de dinheiro e, portanto, à dificuldade socioeconômica, o que produz o núcleo temático da dificuldade financeira e da pobreza que recobre grande parte dos textos. Em $O$ quarto alugado temos uma das maiores expressões da disforia que reveste o espaço interior pelo qual se movimenta o ator do enunciado e que se vincula, também, ao tema da carência econômica.

\footnotetext{
Eles seriam bastante felizes enquanto o dinheiro durasse (Tradução nossa).

32 Por dois ou três dias ela saiu em busca de alunos (Tradução nossa).
} 
O conforto ilusório se exibia nos vislumbres da mobília arruinada - o estofamento de brocado puído de um sofá e duas poltronas, o espelho barato alongando-se entre duas janelas, uma ou duas gravuras de moldura dourada, uma cama de metal a um canto. [...] A mobília estava contundida e lascada; o sofá, de molas rebentadas, parecia um monstro disforme, abatido pelo ímpeto de alguma convulsão grotesca. Um cataclisma mais violento arrancara um pedaço do mármore da lareira. Cada tábua do assoalho possuía uma inclinação própria e um rangido peculiar, como se padecesse uma agonia individual e distinta (O. HENRY, 1988, p. 88).

Observamos, dessa maneira, uma preferência no olhar de O. Henry para os ambientes internos e, principalmente, para a figurativização que encaminha esse olhar a uma focalização que "faz ver" atmosferas de pobreza e necessidade. Um olhar que perscruta o habitat das massas humanas e que explora o perímetro espacial de deslocamento dos sujeitos. Muitos são os contos que fazem uso de tal recurso para figurativizar o alhures. Ora, essa maneira específica de movimento por entre os espaços que cercam e envolvem os sujeitos ajuda a compor a identidade social do enunciador, definida e afirmada, pois, pelo modo próprio de descrição de uma estrutura que se apóia em bases fundamentais como rico/pobre, dentro/fora que engendram as práticas em sociedade. Os textos nos mostram que é por esse crivo gerador categorial que a construção da espacialidade se pauta. Além disso, os ambientes internos despontam como o ideal topológico do enunciador, pois, assim, torna possível investigar o ser dos sujeitos em seus espaços mais íntimos e revelar, pela categoria da interioridade, a própria interioridade dos sujeitos. Trata-se, pois, de mostrar um universo social e as peças que o compõem.

No que concerne à instalação dos atores nos contos de O. Henry, podemos dizer que há uma preferência pela figurativização dada a casais, fundamentalmente, marido e mulher e namorados. São vários os exemplos dentro da produção do autor, pois a estrutura que funda a relação amorosa se repete ao longo do discurso. Vemos, dessa forma, pela aproximação dos contos da totalidade literária que a configuração discursiva do "amor" é sempre abordada e, por conseguinte, figurativizada e tematizada. Falaríamos, assim, em uma configuração discursiva actorial, uma vez que a base comum e invariante - casal - desponta nos textos.

Estamos diante, dessa maneira, de uma única estrutura actancial figurativizada onomasticamente de modo diverso. Ainda, os atores se avizinham por uma constituição mais profunda sugerida por Greimas e Courtés ([1983], p. 34): “Acrescentamos que o ator não é somente 
investimento desses papéis, mas, também, de suas transformações, consistindo o discurso, essencialmente, em um jogo de aquisições e perdas sucessivas de valores".

A recorrência dos papéis temáticos de homem e mulher, subsumidos pelo termo "casal", assim como averiguado em $O$ presente dos magos, relaciona-se à determinação de uma mesma posição do percurso do ator no desenvolvimento narativo. Tal regularidade na forma de compor os atores do enunciado nos leva a entender como "Della e Jim" se integram a um conjunto muito mais vasto e generalizado. A aplicação dos procedimentos de actorialização, no momento da enunciação, revelam o estoque actorial ao qual O. Henry recorre, pois como declaram Greimas e Courtés ([1983], p. 75): “tal intervenção pressupõe, vê-se, um sujeito da enunciação dotado não somente da competência narrativa, mas também de um estoque de configurações discursivas acompanhado, por assim dizer, de seu 'modo de usar'".

\subsection{O perfil do narrador em O. Henry}

Compete-nos, nesse momento, verificar a presença do narrador nos contos de O. Henry para que possamos estabelecer uma imagem de enunciador e de enunciatário pelas recorrências mostradas. Em O presente dos magos, averiguamos um narrador pontual, que lança mão de apreciações sobre os atos dos atores do enunciado. Afirmamos, pois, que este é o tipo de narrador que atravessa as narrativas do autor. Um narador que explicita um tipo de "saber" que conduz o narratário a um crer na validade dos julgamentos pautados na prudência e na sensatez. Tal é o tom assertivo e moralizante que remete indistintamente ao do enunciador. Esquematizamos, a seguir, passagens de narradores dos contos da totalidade literária, para que, aproximados, possamos observar um modo de ser do enunciador pela maneira que institui recorrentemente narradores nos contos.

\begin{tabular}{|l|l|}
\hline 1. A Service of Love & $\begin{array}{l}\text { When one loves one's art no service seems } \\
\text { too hard. That is our premise. This story }\end{array}$ \\
shall draw a conclusion from it, and show at \\
the same time that the premise is incorrect. \\
That will be a new thing in logic, and a feat \\
in story-telling somewhat older than the
\end{tabular}




\begin{tabular}{|c|c|}
\hline & Great Wall of China $(1995$, p. 21$){ }^{33}$ \\
\hline 2. O quarto alugado & $\begin{array}{l}\text { A maior parte da população do distrito } \\
\text { proletário do baixo West Side é inquieta, } \\
\text { errante e fugaz como o próprio tempo. Sem } \\
\text { possuir lar próprio, os habitantes dessa zona } \\
\text { têm uma centena de lares. Pulam de quarto } \\
\text { alugado para quarto alugado, } \\
\text { permanentemente nômades: nômades de } \\
\text { moradia, nômades de coração e pensamento. } \\
\text { [...] Daí as casas desse bairro, tendo tido mil } \\
\text { moradores, terem mil histórias a contar, na } \\
\text { maioria tristes, por certo (1988, p 86). }\end{array}$ \\
\hline 3. The Brief Debut of Tildy & $\begin{array}{l}\text { If you do not know Bogle's Chop House and } \\
\text { Family Restaurant it is your loss. For if you } \\
\text { are one of the fortunate ones who dine } \\
\text { expensively you should be interest to know } \\
\text { how the other half consumers provisions } \\
(1995, \text { p. } 80)^{34} \text {. }\end{array}$ \\
\hline
\end{tabular}

O enunciador expõe freqüentemente dramas de relacionamento interpessoal, avaliados pela instalação de um narrador altamente judicativo das ações humanas. Se em $O$ presente dos magos o tempo empregado para as intromissões do narrador é sempre o do presente, nos trechos escolhidos averiguamos o mesmo uso temporal, o que confirma e radica um enunciador que se direciona a expor verdades. Os verbos, principalmente o verbo ser, utilizados no presente remetem a asserção e a sabedoria de quem expõe pontos de vista tidos com válidos. Há, dessa maneira, em O. Henry uma vocalidade manifestada por meio de um tom assertivo (moral) dos narradores que remete em última instância ao do enunciador: Essa é a voz que ressoa nos textos, voz esta pautada por tom que varia do humor a acidez para fazer valer um tipo de verdade sobre os fatos. A apreciação, segundo Charaudeau e Maingueneau (2004, p. 50), "recobre, então, tudo aquilo que diz respeito à reação afetiva ou de julgamento de valor".

33 Quando alguém ama sua arte nenhum serviço parece tão difícil. Essa é a nossa premissa. Esta história deve tirar uma conclusão disso, e mostrar ao mesmo tempo que a premissa está incorreta. Isso será uma coisa nova em lógica, e uma façanha no contar histórias, mais antiga do que a Grande Muralha da China (Tradução nossa).

34 Se você não conhece a Casa de Costeletas do Bogle e o Restaurante Familiar, você é quem perde. Pois se você é um dos afortunados que comem de modo caro, você deveria se interessar em conhecer como a outra metade dos consumidores se abastecem (Tradução nossa). 
É apresentado, assim, segundo um saber do enunciador, como deve ser o comportamento dos outros, ao demonstrar comportamentos vinculados a expectativas de condutas humanas. Isso nos faz aceder diretamente ao enunciador, pois como afirma Maingueneau (2001a, p. 139) "o texto está sempre relacionado a alguém, uma origem enunciativa, uma voz que atesta o que é dito". Tal voz estando ligada, então, a uma origem enunciativa revela a interioridade de um sujeito que leva o coenunciador a incorporar um imaginário criado pelo modoespecífico de enunciação.

A partir do narrador, podemos, também, fazer referência a um outro aspecto marcante nos contos: a consolidação de mecanismos de conversa com o leitor. Assim, como visto em $O$ presente dos magos, tal característica é explicitada na totalidade. Um exemplo retirado de The Brief Debut of Tildy assenta nossas constatações: “And if you belong to the half of whom waiters' checks are things of moment, you should know Bogles 's, for there you get your money's worth - in quantity, at least ${ }^{35}$ (O. HENRY,1995, p. 80). Esse artifício usado por O. Henry, tendo como ponto de partida narrador e narratário, define um enunciador que busca criar um contrato veridictório próprio. $\mathrm{O}$ enunciatário é levado a crer em um mundo criado pelo enunciador, de acordo com concepções e exame de uma determinada realidade. $\mathrm{O}$ enunciador, dessa forma, apresenta ao enunciatário um mundo não idealizado, mas sim repleto de disjunções. Disjunções essas que rodeiamo homem.

Um narrador que demonstra, ainda, gosto pelo uso de metáforas, como em $O$ presente dos magos:

\footnotetext{
"Despenhou-se, ondulante, a cascata de águas castanhas.

- Vinte dólares - ofereceu Madame, erguendo a massa com mão prática.

- Dê-me o dinheiro depressa - pediu Della.

Oh, as duas horas seguintes voaram com asas róseas. Perdoe-se a metáfora gasta." (grifo nosso)
}

O emprego dessas metáforas nos conduz a observar, também, da parte do narrador, a tendência a concretizar numa figurativização peculiar como:

a) em O presente dos magos: "Jim avançou alguns passos, tão rígido quanto um perdigueiro. na pista de uma codorniz";

35 Se você pertence à metade daqueles em que a verificação do garçom é coisa de momento, você deveria conhecer o Bogle's, pois lá o seu dinheiro vale - em quantidade pelo menos (Tradução nossa). 
b) em $O$ quarto alugado: "ele percorreu então o aposento como um perdigueiro na pista, perscrutando as paredes, examinando de gatinhas, os campos do tapete saliente" (O. HENRY, 1988, p. 89).

Não poderíamos terminar nossas análises sem mencionar o uso da "isotopia do secreto", muito marcante nos contos de O. Henry. Como já demonstramos pela análise de $O$ presente dos magos, tal estratégia enunciativa, de prolongamento narrativo até o desvendar de um segredo, permite ao enunciador manter a adesão do enunciatário ao texto, por meio de uma doação lenta de um saber sobre o desenrolar da narrativa. Recuperamos um trecho de $O$ quarto alugado para demonstrar o emprego desse recurso discursivo na obra do autor. Depois do suicídio do rapaz com gás por não ter encontrado quem procurava, a revelação de um segredo demonstra um desfecho surpreendente.

Era a noite de Mrs. McCool sair com o canecão a buscar cerveja. Ao trazê-la de volta, sentou-se com Mrs. Purdy num desses antros subterrâneos onde as senhorias costumam se reunir e onde os vermes raramente jejuam.

- Aluguei o quarto dos fundos, no terceiro, hoje à tarde - disse ela a Mrs. Purdy, atrás de um belo círculo de espuma. - Aluguei-o a um rapaz; ele já se deitou há duas horas.

- Não diga, Mrs. Purdy! - exclamou Mrs. McCool, com intensa admiração. - A senhora é um colosso para alugar quartos como esse. E contou-lhe tudo? concluiu num murmúrio rouco, carregado de mistério.

- Quartos - disse Mrs. Purdy, com sua voz mais felpuda - são mobiliados para alugar. Não contei nada, Mrs. McCool.

- Tem toda a razão; é alugando cômodos que ganhamos a vida. Tem muito jeito para negócios, dona. Muita gente recusaria um quarto ao saber que alguém se suicidou na própria cama que ali está.

- Como diz, temos que ganhar a vida - observou Mrs. Purdy.

- É mesmo, é verdade. Faz uma semana hoje que ajudei a senhora a pôr em ordem o quarto dos fundos, no terceiro. Era uma moça tão bonita, bonita demais para se suicidar com gás! E que carinha linda tinha!

- Poderíamos dizer que era um tipo de beleza - assentiu Mrs. Purdy, com certo ar de crítica -, não fosse o sinal preto junto da sobrancelha esquerda. Mais um pouco de cerveja, Mrs. McCool? (O. HENRY, 1988, p. 90 - 91). 
Os excertos retirados desses contos do escritor possibilitam, juntamente com aquelas de O presente dos magos nos possibilitam, expor quem é o enunciador dos textos de O. Henry, e ainda mais, quem é o "O. Henry" apresentado pelos textos. Resta-nos, então, reunir tudo o que foi encontrado e extrair uma imagem de enunciador e enunciatário. O éthos, compreendido como a imagem do enunciador construída por um modo recorrente de dizer, revela um sujeito "em um quadro profundamente interativo, em uma instituição discursiva inscrita em uma certa configuração cultural e que implica papéis, lugares e momentos de enunciação legítimos, um suporte material e um modo de circulação para o enunciado" (MAINGUENEAU, 2005b, p. 75).

Pelo exame dos textos da totalidade literária, verificamos, assim, que a fala assertiva do enunciador implica, por sua vez, em um caráter e em uma corporalidade. O caráter, constituído por um feixe de traços psicológicos, encaminha-se para um conjunto de “estereótipos específicos de uma época, de um lugar, que a literatura contribui para validar e nos quais se apóia” (MAINGUENEAU, 2001a, p. 139). O enunciador mostra, assim, por suas apreciações um caráter judicioso de quem revela acerto, juízo e sensatez: "But the best, in my opinion, was the home life in the little flat"36 (O. HENRY, 1995, p. 22).

Chegamos a um corpo de um enunciador que se aproxima e passeia por entre a massa humana com seus pequenos dramas diários e que, por assim dizer, faz circular uma determinada esquematização do corpo e encarnar um modo de presença no mundo. Um corpo de um ser ativo, reforçado por uma héxis corporal distensa pela maneira dinâmica de habitar o espaço social, que percorre as interioridades e as exterioridades por onde se deslocam os sujeitos para desvendar o modo de vida daqueles que sofrem com a dor da falta. Um corpo que sente, portanto. Em relação à corporalidade, Maingueneau nos afirma que:

Quanto à corporalidade, é associada a uma compleição do corpo do fiador, inseparável de uma maneira de se vestir e se movimentar no espaço social. O etos implica portanto um policiamento tácito do corpo, uma maneira de habitar o espaço social. Longe de surgir todo armado do imaginário pessoal de um autor, constitui-se através de um conjunto de representações sociais do corpo ativo em múltiplos domínios (MAINGUENEAU, 2001a, p. 139).

36 Mas, o melhor, em minha opinião, era a vida de casa no pequeno apartamento (Tradução nossa). 
Os espaços visitados por esse corpo social intensificam uma corporalidade que se identifica com a do vivente. Esse trânsito do corpo faz emergir, portanto, um contexto que agrega modos de ser: diferenças sociais, pobreza, sacrifícios, desilusões amorosas; tudo entremeado ao dissabor das disjunções humanas. O co-enunciador, por sua vez, incorpora esse conjunto de esquemas do enunciador e se identifica "com uma certa determinação de um corpo em movimento, apreendido em seu entorno social" (MAINGUENEAU, 2001a, p. 146). Interessante notar que o éthos/páthos em O. Henry se constitui a partir da expressão desse corpo em deslocamento por um mundo social, isto é, por um "espace pratique de l'existence quotidienne" (BOURDIEU, 1979, p. $189)^{37}$. Ao percorrer o espaço das "pessoas comuns", vemos um corpo que sente a carência que preenche o destino e a natureza humana dada segundo uma falta sentimental ou socioeconômica.

Dessa forma, O. Henry, por meio de ironias que têm como alvo sentimentalismos, elimina a credulidade, introjetando nos contos percalços narrativos cheios de incompletudes. $\mathrm{Na}$ enunciação, então, fica decretado que a falta é constitutiva do homem. Estabelece-se no enunciado o tema do amor duradouro em direção à completude do sujeito como um valor fundamental para a vida a dois, uma sabedoria cristalizada por um amor desprendido e partilhado, independentemente das dificuldades. Sobre isso Garcia (1966,p. 123) afirma:

\footnotetext{
Se o amor estiver presente, a vida pode ser uma grande aventura que transcende toda a sordidez, mas se estiver ausente, nada mais pode tomar o seu lugar. Inversamente, como está freqüentemente ausente - ou, quando presente, existe apenas momentaneamente e em estado frágil - o mundo pode reconhecer e sentir o triste significado da vida sem ele.
}

Há inscrito nos contos, dessa maneira, a imagem de um enunciatário cooperativo, com a competência para saber ler implícitos, um enunciatário (páthos) cético que incorpora o éthos cético do enunciador. Cético porque faz ver as mazelas humanas e direciona o foco para um julgamento sobre o mundo "que impregna o sujeito e que é reconstruído por ele, para que ele, sujeito, também se construa na totalidade de seus discursos. Assim se projeta a imagem-fim que, por motivar esse ator, constitui um simulacro sempre presente na totalidade" (DISCINI, 2003, p. 74). A voz da razão do enunciador que critica e afirma é responsável pela moralidade que impõe um sentido ao dito. Uma

\footnotetext{
37 Espaço prático da existência cotidiana (Tradução nossa).
} 
moralidade que carrega um juízo sobre a narrativa e permite a enunciação entrar explicitamente no enunciado.

O páthos dado como imagem determinada por escolhas enunciativas afirma um leitor implícito que relativiza a eficácia do discurso. A imagem do enunciatário construída pelos textos de O. Henry respalda-se por uma concretização daquele que aprecia ironias, daquele que mantém um estado cético de espírito. O autor espera um sujeito que constrói de si e para si o simulacro de quem quer, deve, sabe e pode garimpar o sentido do texto e da vida para além do dado. Os argumentos construídos por $\mathrm{O}$. Henry projetam a imagem do enunciatário que aprecia o distanciamento emocional necessário para poder, metalingüisticamente, entender que está diante de um texto literário. $\mathrm{O}$ auditório previsto para esses argumentos tem a disposição para o ceticismo existencial, além de um certo cansaço no que diz respeito às relações amorosas. Revela-se um estilo que apresenta, portanto, um ponto de vista sobre o mundo. 


\section{Capítulo IV - Estudo dos textos interpretativos: o éthos do leitor escolar}

\subsection{O texto interpretativo escolar}

O exame semiótico dos textos interpretativos nos permitirá chegar a um corpo, uma voz, um tom de voz: um éthos, enfim. Ressalvamos, contudo, que não iremos depreendero éthos de um leitor escolar de todas as escolas de todos os níveis. Nosso corpus possibilita a depreensão do éthos do leitor da totalidade recortada de textos interpretativos. Teremos, então, o éthos do leitor escolar do ensino médio de uma determinada escola estadual do interior do Estado de São Paulo. Dessa maneira, a partir da premissa de que cada produção escolaré um enunciado com uma enunciação pressuposta, veremos como e por que os textos $(\mathrm{T} 1, \mathrm{~T} 2, \mathrm{~T} 3, \mathrm{~T} 4 \ldots)$ remetem a uma totalidade.

As vinte e cinco produções escritæs recolhidas formam uma totalidade discursiva (totus), isto é, uma classe de alunos leitores, que remete ao unus, objeto recortado para análise. A partir desse conjunto de textos, podemos considerar essa totalidade assim como Greimas e Courtés ([1983], p. 55) que apontam para a existência de um actante coletivo: "diz-se que um actante é coletivo quando, a partir de uma coleção de atores individuais, acha-se dotado de uma competência modal e/ou de um fazer comum a dos atores que subsume".

Ainda como afirmam Greimas e Courtés ([1983], p. 55), “o actante-coletivo paradigmático constitui-se, também, a partir de uma totalidade de alunos de uma classe" não sendo, portanto, uma "simples soma de cardinais", mas por formar "uma totalidade intermediária entre uma coleção de unidades e a totalidade que os transcende”. Dessa forma, podemos observar o actantecoletivo, entendido como sujeito único a ser depreendido de todos os textos escolares em pauta.

O número de vinte e cinco produções escolares coletadas pareceu-nos suficiente para poder examinar a estruturação de um texto interpretativo. Tal constatação advém do fato de que, pela análise dos elementos constitutivos de tais textos interpretativos, já notamos reiterações no que diz respeito à recuperação dos níveis profundo, narrativo e discursivo do texto-fonte. Essa reiteração nos direciona a encontrar um paralelismo e uma homogeneidade na competência para produzir textos, 
uma identidade, portanto. De acordo com Greimas e Courtés ([1983], p. 223): “a identidade serve para designar o traço ou o conjunto de traços [...] que dois ou mais objetos têm em comum".

Os alunos apresentam, dessa maneira, uma identidade no modo de enunciar, observada pelo exame dos textos escolares, fazendo com que a generalização de um modo recorrente de ler e interpretar seja depreensível dos próprios textos.

A identidade serve igualmente para designar o princípio de permanência que permite ao indivíduo continuar o "mesmo", "persistir no seu ser", ao longo de sua existência narrativa, apesar das modificações que provoca ou sofre. Também e da mesma maneira é ao conceito de identidade a que nos referimos quando falamos da permanência de um actante apesar das transformações de seus modos de existência ou dos papéis actanciais que ele assume no seu percurso narrativo, da permanência também de um ator discursivo no decorrer do discurso no qual ele está inscrito (GREIMAS e COURTÉS, [1983], p. 223).

Dessa forma, buscamos entender as relações do texto-fonte com os textos interpretativos escolares, para, a partir da interpretação, verificar o movimento de captação identidades ou alteridades estruturais construídas a partir do texto-fonte. O conto de O. Henry é a condição de construção de sentido do discurso dos textos dos alunos. Nesse ponto, devemos descrever a significação do conto literário e dos textos escolares, observando a estruturação das duas totalidades, desde o patamar mais elementar da significação até o nível mais superficial, pelas relações que eles entretêm. É no cotejo entre as estruturas do texto-fonte e dos textos interpretativos que podemos começar a pensar, em termos da semiótica francesa, nos princípios que regulam a interpretação enquanto captação de um texto-base.

$\mathrm{Na}$ desconstrução das estruturas dos textos que compõem a totalidade escolar em questão, formada pelos textos interpretativos escolares, nos será dado a conhecer a "orientação de um sujeito social, histórico, que imprime sua intencionalidade ao que é dito, ao como é dito e ao porquê é dito" (DISCINI, 2002, p. 12). É possível compreender então o porquê do modo de construção dos textos interpretativos por enunciadores escolares. Isso permitiu a perceber que a organização das estruturas dos textos escolares descortina um determinado aspecto do ensino de interpretação textual, uma vez que tal contexto deixa-se resgatar por meio da própria existência da estrutura dos textos escolares. A partir do exame que será feito do processo de recepção, então, temos como proposta descrever a organização de um texto interpretativo produzido por leitores escolares. 
As produções dos alunos leitores seguem transcritas na íntegra em anexo, respeitando a textualização dos produtores. Assim, problemas de ortografia, concordância entre outros, foram mantidos para não descaracterizar o original.

\subsection{Abordagem semiótica dos textos interpretativos escolares}

As produções interpretativas serão examinadas à luz da teoria semiótica a fim de observar as organizações discursivas, o engendramento narrativo e a articulação fundamental dos textos dos alunos, para que possa ser feito o cotejo com o texto-fonte. A instância de recepção leva a uma recriação dessas organizações constitutivas do discurso. Tal "recriação" nos permite verificar a fixação do olhar do leitor ao percorrer as estruturas do texto de O. Henry e, fundamentalmente, orientar nossas discussões a respeito do éthos do leitor escolar configurado como um éthos convergente ou divergente da imagem do enunciatário inscrita no conto, um éthos responsivo, portanto.

Além disso, o exame semiótico dos textos interpretativos possibilita investigar o domínio que os leitores escolares apresentam de técnicas mínimas de interpretação. Tocamos novamente na questão do papel da escola na formação de leitores e intérpretes de textos com o intuito de reforçar a função primordial que essainstituição deve exercer.

Gostaríamos, ainda, de estabelecer uma última constatação. De todos os textos escolares recolhidos, uma diferenciação entre eles deve ser feita. Dessa forma, podemos separá-los em três grandes grupos. O primeiro diz respeito aos textos que se ordenam como paráfrases completas do texto-fonte, uma vez que se apresentam como "cópia literal", dada as devidas reduções, do texto literário para leitura. $\mathrm{O}$ segundo grupo abarca os textos que se constroem segundo um resumo pessoal do conto de $\mathrm{O}$. Henry. O terceiro, por sua vez, agrupa produções que mais se aproximam de um texto interpretativo, pois os alunos demonstram como apreendem alguns temas de $O$ presente dos magos e como os captam. Notamos, assim, que a constituição dos textos escolares se funda da paráfrase à apreensão de alguns temasdo texto literário.

A estreita vinculação das produções interpretativas ao texto-fonte nos autoriza a não efetuar uma análise semiótica minuciosa da totalidade escolar, pois estaríamos analisando o conto novamente. $\mathrm{O}$ que importa é verificar a recorrência na recuperação das estruturas do texto literário para poder depreender, a partir de uma focalização do olhar do leitor, um estilo próprio que condiz a 
uma totalidade escolar. Dessa forma, pretendemos abordar semioticamente os textos escolares em busca dos componentes e sub-componentes do percurso gerativo do sentido retomados e reorganizados pelos sujeitos leitores e intérpretes.

\subsubsection{Nível fundamental}

Nas produções interpretativas, que tiveram como base o conto $O$ presente dos magos, os alunos recuperam do texto-matriz a oposição semântica mínima gratuidade vc utilitarismo - presença vs ausência - e constroem seus textos sob essa articulação. Inevitavelmente, de acordo com o fundamento interpretativo da totalidade escolar, todos os textos se apóiam nesses termos básicos.

A averiguação efetuada do nível fundamental dos textos escolares demonstra, portanto, uma recorrência dessa articulação mínima e pode ser visualizada no modelo a seguir do quadrado semiótico:

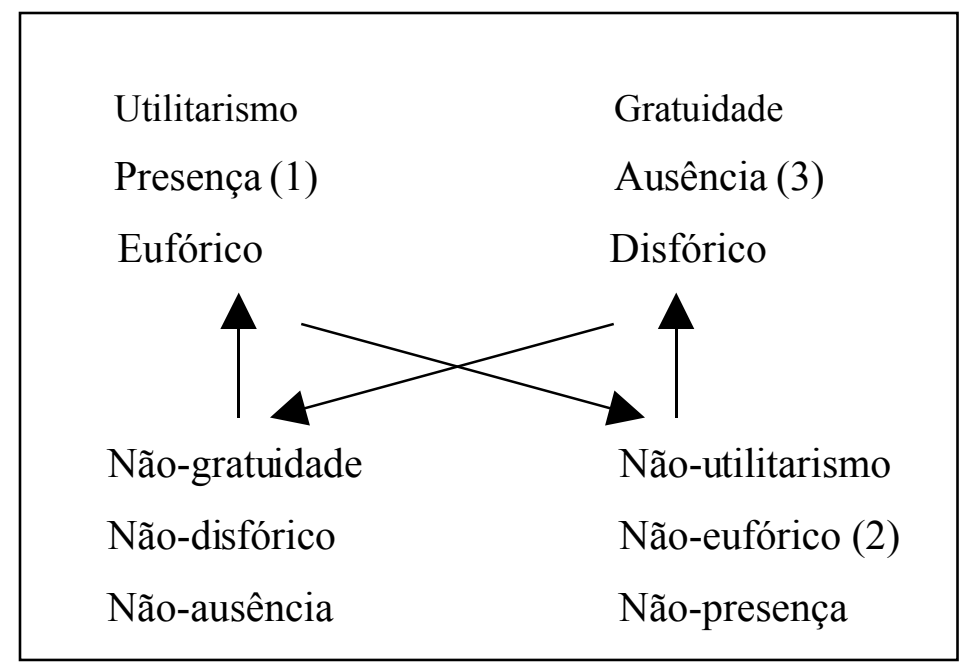

A partir desses dois termos, nossos leitores organizam seus textos em torno da posse (possessão) de objetos materiais e da renúncia (desprendimento) em relação a tais objetos. A partir da valorização de uma determinada isotopia de leitura presente no texto de O. Henry e explicitada pelo final do conto, os alunos pregam a conjunção com o objeto "amor" como forma de apresentar a eternização da completude do ser humano. Temos, então, a recuperação da conjunção, dada pelo 
valor argumentativo do texto criado pelo caráterfabular de seu final. Os textos dos alunos focalizam, portanto, a moral presente no conto parasuplantar a disjunção.

Os sujeitos leitores negam, portanto, afirmam a única possibilidade do fazer do homem no mundo: um homem sempre em conjunção. Pelos finais de alguns textos escolares essa característica discursiva de nossos leitores pode ser comprovada:

Foi então que Jim e Della envolvidos com o espírito Natalino que se aproximava descobriram que o que realmente importa é a intensão de agradar uns aos outros com amor e compreensão. (ANEXO B, texto 1, p. 172)

Ali os dois se olharam e riram pois eles intenderem que por mais que seja dificil a vida o amor deles compensava tudo. (ANEXO B, texto 9, p. 175)

E esse texto mostra que eles são um casal muito unido, acima de qualquer coisa, venceram juntos o que mais gostavam para fazer um ao outro feliz, naquela véspera de natal. (ANEXO B, texto 12, p. 177)

Deixaram os presentes de lado e se abrasarãm e viram que o maior presente que pudessem dar um ao outro era o amor e o amor dos dois já compartilhavam. (ANEXO B, texto 18, p. 180)

E chegou o grande dia de Natal Jim colocou seu presente: Mas o não importa o presente que se dá mais a sim a intenção que é dado. (ANEXO B, texto 23, p. 183)

Por outro Jim estava na mesma situação, para dar um presente para Della também teve que desfazer de uma das coisas que mais gostava, vendeu o seu relógio para comprar um belo presente par Della.

Isto mostra como o amor dos dois é tão grande eles abriram mão do que mais gostavam só para agradar um ao outro. (ANEXO B, texto 24, p. 184)

Della ganha o presente que tanto queria, os pentes que tanto namorara na vitrine da loja; enquanto seu marido acabou com um presente que parecia ser bonito, mas de nada serviria. 
Mas o que realmente importa, nem sempre é o presente si, mas sim a intenção, o amor, o carinho que leva a pessoa a dá-lo. (ANEXO B, texto 25, p. 184)

A conjunção, euforizada, passa a ser tematizada pela possessão amorosa e figurativizada pelo enamoramento nos textos de leitura. Dessa maneira, observamos a seguinte articulação fundamental nas produções interpretativas: (1) ausência $\rightarrow$ (2) não-ausência $\rightarrow$ (3) presença. Negase a ausência em um movimento em direção à presença. $\mathrm{O}$ contrário se dá no conto-matriz.

Encontramos na estruturação do nível fundamental uma recorrência primeira no olhar do leitor que, ao perscrutar o texto-fonte, de lá resgata e recria tal movimentação de termos mínimos de articulação do sentido. Temos um leitor que se apropria de um par de termos categoriais advindos do ato de leitura e que os reordena a seu modo próprio nos textos interpretativos, o que já deixa transparecer aceitações e rejeições de determinadas axiobgizações pertencentes ao conto de $\mathrm{O}$. Henry na confirmação de um efeito de individualidade. Como afirma Discini (2003, p. 44):

Uma escolha tímica fundamental, tendo determinado dêixis como eufóricas ou disfóricas e tendo orientado escolhas axiológicas, deve, lembremos, também, fundamentar a construção ideológica desse efeito de individualidade.

Essa recuperação apresenta-se como uma peça inicial que nos permitirácompor um estilo e, conseqüentemente, o éthos do leitor escolar, a partir de um determinado olhar sobre o mundo, o que radica um ator da enunciação subjacente às interpretações escolares.

\subsubsection{Nível narrativo}


Se recuperarmos o esquema básico da ação, dividido sumariamente em situação inicial e final, podemos visualizar a estruturação narrativa basilar dos textos interpretativos. Nessa segmentação, empregamos critérios narrativos, pois eles asseguram uma homogeneidade na construção inicial e final das produções escolares, apesar de algumas variaçõesnarrativas se disseminam ao longo dos vinte e cinco textos conforme os diferentes modos de redução do textofonte. Ressaltamos com isso que certos elementos foram explicitados por alguns leitores e outros não. De toda maneira, elementos convergentes são encontrados emtodos os textos, o que garante a permanência de um modo próprio de olhar o outro (texto para leitura) e, retomar dele, em um processo sintetizador, as estruturas que mais julgaram importantes.

\begin{tabular}{|l|l|}
\hline Situação inicial & Situação final \\
\hline Disjunção material & Conjunção espiritual \\
\hline
\end{tabular}

Nossos leitores de O. Henry captam as bases semânticas do conto, para o fim específico de expor o que entenderam do texto. Para isso, constroem seus comentários parafrásticos e explicações. Nesse sentido, no que concerne à captação do nível narrativo do texto-matriz, todos os leitores começam seus textos pela disjunção material flagrante do início de $O$ presente dos magos.

O foco do leitor se deteve inicialmente nessa característica do conto, uma vez que a tensão patêmica estabelecida pelas relações de despossessão material atraiu de imediato o olhar do leitor para a captação desse estado narrativo no qual se encontra o actante-sujeito Della. Alguns excertos validam essas constatações:

Era véspera de Natal, Della se sentia angustiada e chorava tinha apenas um dólar e oitenta e sete centavos, era pobre sem muito conforto, vivia em um apartamento mobiliado por oito dólares semanais no dia seguinte era Natal. (ANEXO B, texto 14, p. 179)

Era véspera de natal e Della tinha apenas um dólar e oitenta e sete centavos. Queria muito dar um presente para seu marido Jim, porém o único dinheiro que tinha era aquela mesquinhez, resultado de suas economias. (ANEXO B, texto 19, p. 181) 
O texto Presentes de Reis Magos mostra um casal de jovens humildes.

Della era uma dona de casa que tinha um dolar e oitenta e sete centavos para compra um presente para seu marido, pois era natal no dia seguinte. (ANEXO B, texto 20, p. 182)

Um dolar e oitenta e sete centavos. Era tudo que Della tinha para comprar um presente. Para Jim. Seu amado Jim. (ANEXO B, texto 21, p. 182)

Encontramos, ainda nos trechos selecionados, uma situação inicial determinada por um estado tenso-disfórico que assinala para o sujeito uma falta ou uma ausência do objeto-valor desejado. A ausência se apresenta, assim, bem marcada pelos sujeitos leitores, o que demonstra uma prioridade na recuperação do estado disjuntivo de um sujeito que sofre. Os alunos intérpretes resgatam maciçamente do conto literário um momento de dor e sofrimento ao manifestar interesse pela ausência. A organização modal querer-ser + não saber-poder-ser caracteriza a espera simples de Della em relação ao objeto de valor visado. O sujeito deseja entrar em conjunção, mas não sabe o que fazer para consegui-lo.

De um modo geral, os textos da totalidade escolar, a partir desse estado inicial de falta, explicitam dois pontos na organização narrativa: o percurso de Della para a aquisição de dinheiro com a venda do cabelo e o momento de troca de presentes entre Della e Jim - os dois actantessujeitos implicados.

Della está em uma situação de não-possessão (S U Ov riqueza, bens materiais) e vai realizar transformações para entrar em uma situação de possessão com tais bens materiais (Ov descritivos). A respeito de objetos de valor descritivos, Barros (2001, p. 46) diz que "os valores descritivos, por sua vez, classificam-se em valores objetivos (consumíveis e armazenáveis) e em subjetivos (prazeres, estados de alma)". Isso indica que Della quer entrar em conjunção com um valor que lhe proporcione a "satisfação" de agradar seu marido. Lembramos, ainda, como também atesta Barros (2001, p. 45), "a escolha de valores corresponde a uma primeira decisão do sujeito da enunciação, quanto ao discurso que será produzido".

Nessa busca pela reparação da falta, o querer de Della também foi amplamente explicitado nas produções escolares. 
Era véspera de natal e Della queria muito comprar um presente para o seu marido (grifo nosso). (ANEXO B, texto 3, p. 173)

Temos um querer que impulsiona o homem às ações e, que, de algum modo, demonstra um posicionamento frente às dificuldades. A força do querer, que leva a um fazer e, por conseguinte, a um ser, permite-nos conceber o percurso narrativo de Della como permeado pelo sacrifício para agradar o marido. Eis aí um dos motivos da identificação do leitor escolar que, ao enfatizar as estruturas de venda do Ov (cabelo), euforiza as atitudes de Della. Essa identificação feita pelo leitor em relação ao percurso do actante-sujeto Della está inscrita nas próprias redaçõesescolares.

Della saiu nas ruas a procura de um presente para Jim mas tinha pouco dinheiro, ela encontrou uma mulher que compraria seus cabelos a coisa mais valiosa que ela tinha, ela queria muito dar um presente para Jim. Mandou cortar seus cabelos para ganhar Vinte dólar (ANEXO B, texto 2, p. 172)

Della teve a idéia de sacrificar seu cabelo para comprar o presente para seu marido Jim. (ANEXO B, texto 23, p. 183)

Della está modalizada pelo saber-poder-fazer, tornando-se assim um sujeito competente, desde que se exponha ao programa narrativo de privação do objeto cabelo. Esse objeto representa, assim, a possibilidade de realização do sujeito, que constrói de si e para si um simulacro positivo pela possibilidade de reparação da falta inicial. O "cabelo" define, também, uma espera fiduciária, pois Della acredita que Madame Sofronie a colocará em conjunção com outro objeto de valor descritivo (dinheiro). A figura do cabelo representa, também, o poder-ser e o crer-ser para um sujeito do querer-ser (Della).

Dessa forma, os textos interpretativos apreendem do texto-fonte as seguintes organizações narrativas:

1) Actante-sujeito (Della) disjunto do Ov (dinheiro, poder-comprar);

2) Actante-sujeito (Della) disjunto do Ov (cabelo, beleza, orgulho), mas conjunto com o Ov (dinheiro, poder-comprar);

3) Actante-sujeito (Della) conjunto com o Ov (presente, agradar o marido, satisfação). 
Os textos interpretativos se organizam, então, de acordo com a estruturação básica dada neste diagrama:

\begin{tabular}{|c|c|c|}
\hline Situação inicial & Desenvolvimento narrativo & Situação final \\
\hline $\begin{array}{l}\text { Disjunção material (dinheiro } \\
\text { e presentes) } \\
\text { Estado de falta }\end{array}$ & $\begin{array}{l}\text { Venda do Ov (cabelo) } \\
\text { Aquisição de Ov (dinheiro) } \\
\text { Troca de presentes }\end{array}$ & $\begin{array}{l}\text { Conjunção espiritual com os } \\
\text { valores do "amor" } \\
\text { Liquidação da falta }\end{array}$ \\
\hline
\end{tabular}

Alguns leitores das redações escolares explicitam também o percurso narrativo de Jim, análogo ao de Della. O actante-sujeito Jim entra em disjunção de um objeto-valor para adquirir outro. A troca de objetos também não é apresentada por todas as produções interpretativas. Dessa forma, nem todos os sujeitos escolares puderem apreender o movimento de troca de presentes e, principalmente, reconhecer os efeitos de sentido criados por tal organização no nível narrativo.

Cumpre reforçar, assim, que os finais dos textos interpretativos apresentam para os actantes-sujeitos do conto uma conjunção com os valores do "amor"; conjunção que liquida a falta socioeconômica. De um modo ou de outro, os sujeitos leitores terminam suas produções escolares apresentando um tipo de compensação para a falta, diferentemente do conto de O. Henry que é finalizado por uma suspensão na conjunção: “que tal se vocêfritasse as costeletas?"

Ali os dois se olharam e riram pois eles intenderem que por mais que seja dificil a vida o amor deles compensava tudo (ANEXO B, texto 9, p. 175)

Deixaram os presentes de lado e se abrasarãm e viram que o maior presente que pudessem dar um ao outro era o amor e o amor dos dois já compartilhavam (ANEXO B, texto 18, p. 180)

Mas o que realmente importa, nem sempre é o presente si, mas sim a intensão, o amor, o carinho que leva a pessoa a dá-lo. (ANEXO B, texto 25, p. 184) 
Ainda, no nível narrativo, convém determinar algumas paixões que aparecem nas produções escritas dos alunos. Como já mencionamos, o estado de falta é descrito por todos os leitores e é, a partir desse estado, que evidenciaremos as paixões instaladas nos textos em questão. Os sujeitos identificam, então, inicialmente, paixões de tristeza e angústia:

Não havia nada a fazer a não ser cair na poltrona remendada e chorar. (ANEXO B, texto 6, p. 174)

Della pensativa, com seus olhos lacrimados, pois se a pensar um tudo e lembrou que ela e seu marido (ANEXO B, texto 12, p. 177)

Era véspera de Natal, Della se sentia angustiada e chorava tinha apenas um dólar e oitenta e sete centavos. (ANEXO B, texto 14, p. 179)

Nas redações escolares, tal qual no conto de base, o sujeito Della tem uma existência modal definida pelo querer-ser, o que torna os objetos buscados por ela desejáveis. Há, portanto, a manutenção da paixão do desejo em todos os textos em análise. Entretanto, o sujeito aparece como desanimado e abatido pelo querer-fazer e não poder-fazer. Tais modalidades aparecem ressaltadas, portanto, no início dos textos dos alunos pelo fato de o actante-sujeito Della estar em disjunção material, o que radica um olhar patêmico intenso do sujeito leitor em relação à despossessão. Essa aproximação patêmica configura-se em função do privilégio dado à falta sofrida pelo sujeito; falta esta dada segundo uma carência que o discurso da totalidade escolar ressalta como socioeconômica. A ausência de recursos financeiros se sobrepõe aos estados emocionais de precariedade, mais nas produções escolares do que no conto de O.Henry.

O leitor da totalidade considerada reconstrói a relação de venda do cabelo, enfatizando a competência modal de Della no momento em que se estabelece uma relação de barganha com o comprador. O objeto-valor, "pulseira de relógio", que antes era desejável e impossível passa a desejável e possível, uma vez que, agora, Della pode comprar o presente para o marido, já que vendeu o cabelo. No que concerne às modalidades do querer-ser, (na dimensão do desejável) tanto Jim quanto Della demonstram uma paixão simples - a paixão do desejo. No percurso de Della fica evidente uma maior intensidade do querer, pois há um desejo intensificado em relação à compra do presente. 
De um estado de disjunção e tensão, Della passa a um estado de conjunção e relaxamento. As produções dos alunos, também, enfatizam o estado de conjunção de Della com o objeto visado e, a partir desse estado, instaura-se a paixão da satisfação e da alegria. Por outro lado, para entrar em conjunção com o objeto-valor visado, Della teve que entrar em disjunção com um outro objeto-valor (seu cabelo). Temos neste caso, uma paixão do querer-não-ser que gera o desprendimento e a generosidade.

Dessa maneira, os textos interpretativos apresentam basicamente paixões que vão da tensão inicial à distensão final:

Seqüência inicial

Tensão:

Impaciência, aflição
Seqüência final

Distensão:

Desprendimento, generosidade

\subsubsection{Nível discursivo}

Nesse nível do percurso gerativo do sentido, poderemos verificar o posicionamento dos leitores escolares ao instalar narradores em seus textos interpretativos, bem como os temas que apreenderam do texto-fonte. A temporalização, espacialização e figurativização enuncivas são recuperadas nas produções escolares somente até os parágrafos finais em analogia ao conto e também constituem motivo de recorrência na construção do estilo do leitor escolar.

Para o tempo, a maioria dos produtores dos textos escolares baseou-se fundamentalmente no "pretérito-perfeito" e no "pretérito imperfeito"; estamos falando em debreagem enunciva. Como textos de comentários parafrásticos, nada melhor para expressar descrições que o uso de imperfeito e expressar narrações, com suas transformações, por meio do emprego do pretérito perfeito. Podemos evidenciar tal uso quando Della e o apartamento são descritos pelo emprego do imperfeito: "Della era muito pobre", "Não era exatamente miserável', "No vestíbulo embaixo havia uma caixa de correspondência na qual carta nenhuma seria posta", “Encontrava-se ali também um cartão anunciando o nome de 'Mr. James Dillingham Young”" (grifos nossos). 
Já o pretérito perfeito é amplamente utilizado para mostrar as transformações ocorridas: "terminou de chorar", "passou pó de arroz", "foi em busca do presente"; "resolveu abrir mão", "vendeu seu cabelo" e "vendeu seu relógio" (grifos nossos).

Devemos observar que em alguns textos o uso do tempo "presente" prepondera, como é o caso da produção número vinte e cinco (ANEXO B, texto 25, p. 184): "mostra", "fazem”, "moram”, "ocorre", "passa", "gostamos", "ganha". Esse presente pode ser descrito como uma neutralização no interior de um mesmo sistema, isto é, há uma embreagem temporal no uso do presente pelo pretérito perfeito. Isto pode ser observado pelos verbos assinalados, pois como diz Fiorin (2002, p. 197) “presentifica-se o acontecimento anterior para mostrar que ele tem uma ressonância no presente, que pesa mais que o passado da ação".

Em relação ao tempo presente e, particularmente, no que se refere ao verbo ser, utilizado pelos alunos para finalizar seus textos, assinalamos que seu estudo será dado com acuidade no item em que nos propomos depreender o éthos do leitor escolar, uma vez que o uso desse verbo e desse tempo permite averiguar um éthos mais contundente, ou um modo contundente de opinar sobre o conto-matriz e sobre o mundo. Dessa forma, para não recair em redundâncias, preferimos tratar desse tópico em momento mais oportuno de nossas análises.

A actorialização é instaurada de duas maneiras nos textos analíticos dos alunos: a) textos em que só aparecem pessoas enuncivas, como Della e Jim, atores do enunciado ou b) produções em que o narrador aparece explicitamente sob a pessoa do eu e ou sob a pessoa do nós. Abaixo, segue um exemplo de cada um desses usos:

Era véspera de Natal, Della desapontada contava o único dinheiro que lhe restara, economizados um a um.

Humildes, Della e Jim, seu marido, moravam num pequeno apartamento e trabalhavam duro para se sustentar. Apesar das dificuldades, Della não se esquecera de seu marido, planejando assim lhe comprar algo que o fizesse feliz. (ANEXO B, texto 1, p. 172)

Eu entendi que Della era uma menina muito sofrida casada com um grnade homem que se chamava Jim. (ANEXO B, texto 8, p. 175)

A história que ocorre na véspera de Natal, nos passa a mensagem de companheirismo, o sacrifício que as vezes passamos para agradar as pessoas que gostamos muito. (ANEXO B, texto 25, p. 184) 
Primeiramente, assim como vislumbrado no texto 1 (ANEXO B, p. 172), o ele é utilizado para o sentido de objetividade do que está sendo relatado. Esse leitor conta o que leu, como que se pudesse distanciar-se dos fatos e não se responsabilizasse por aquilo que está sendo dito. Podemos dizer, então, que o eu está mascarado em terceira pessoa, produzindo apenas actantes do enunciado: Della e Jim. Essa distância entre a instância da enunciação (eu) e do enunciado (ele) cria o efeito de objetividade.

A produção número 8 (ANEXO B, p. 175) apresenta um eu explicitamente instalado no enunciado. $\mathrm{O}$ enunciador se projeta no enunciado por meio de um eu-narrador que relata $\mathrm{o}$ desenvolvimento das ações. O eu demonstra, pela apreciação dos fatos, um efeito de subjetividade. Nesse tipo de interpretação, o leitor se mostra em seu texto, assumindo a responsabilidade por aquilo que é dito. Outras produções ilustram ainda tal marca da enunciação:

Pelo que eu li e entendi Della era uma mulher pobre que amava seu marido Jim. (ANEXO B, texto 13, p. 178)

O que entendi da história, é que um casal apaixonado quer na época do Natal presentear um ao outro mas as condições não estava muito boa para poderem trocar presentes. (ANEXO B, texto 15, p. 179)

Eu pude notar nesse texto um relato de um casal jovên que na vespêra do Natal se deparam com a dura realidade de estarem sem dinheiro, para comprarem presentes um para o outro. (ANEXO B, texto 18, p. 180)

O texto de número 25 apresenta um "nós" projetado no discurso: "Presente de Reis Magos é um texto que nos mostra a dificuldade de dois jovens, que fazem de tudo para agradar um ao outro" (ANEXO B, p. 184 - grifo nosso). Por meio desse pronome, podemos observar a categoria de pessoa "nós" que, de acordo com Fiorin (2003, p. 165):

Nós: não é a multiplicação de objetos idênticos, mas a junção de um eu com um não-eu; há três nós: um nós inclusivo, em que ao eu se acrescenta um $t u$ (singular 
ou plural); um nós exclusivo, em que ao eu se juntam ele ou eles (nesse caso, o texto deve estabelecer que sintagma nominal o ele presente no nós substitui) e um nós misto, em que ao eu se acrescem $t u$ (singular e plural) e ele(s).

Percebemos, assim, que esse aluno da redação 25 utiliza um "nós" para emparelhar o enunciatário ao enunciador, ele próprio aluno-leitor. Assim, o aluno obriga o leitor a assumir o texto com ele. Após o exame de todos os textos escolares, averiguamos que a preferência do leitor repousa pela produção de textos em que a debreagem enunciava é preponderante. O distanciamento do narrador em relação ao narrado perpassa grande parte das produções interpretativas.

O espaço lingüístico dos três textos é o espaço do alhures. Não há menção de uma localização espacial fundada no aqui. Trata-se de "algum lugar" do narrado. A maior parte dos alunos, entretanto, recupera a figura topológica do apartamento, uma vez que esse é o espaço onde os atores do conto vivem seu "drama narrativo".

Além de todos os pontos já examinados, resta observar a disseminação de temas e figuras nos textos analíticos dos alunos. Torna-se evidente que a organização temático-figurativa encontrada nos textos em análise recebe um respaldo no texto de O. Henry, uma vez que o comentário parafrástico é um dos modos de diálogo entre os textos.

Foram detectados, portanto, os seguintes temas principais nas produções escritas

1) tema socioeconômico: concretizado pelas figuras que recobrem diretamente à disjunção com o objeto dinheiro;

2) tema do sacrifício em função do amor: os actantes-sujeitos entram em disjunção com os objetos que mais valorizavam para agradar um ao outro;

3) tema da completude: nas produções, os leitores compensam a falta e para isso constroem o simulacro da completude que supõe paixões tais como: satisfação e alegria. Esse tema é vislumbrado em muitos finais dos textos escritos dos alunos.

Como os textos de nossos alunos trabalham com resumos parafrásticos do texb-fonte, observamos que a coerência narrativa fica prejudicada, pois as estruturas do conto paraleitura são sintetizadas e apresentam, assim, saltos nos percursos narrativos, nãosendo explicitadas, muitas vezes, as aquisições de competências, de objetos etc.

\subsection{O texto interpretativo escolar}


A característica dominante do texto interpretativo dos alunos é sua dependência ao textofonte pela submissão à esfera de sentido do texto disponibilizado para interpretação. A tipologia narrativa toma grande parte da constituição textual devido ao seu estatuto de organização estar fundamentado em um resumo parafrástico do texto-fonte para leitura. Dessa forma, a presença do tipo narrativo se deve ao fato de que no texto literário, este é o que predomina e que, por sua vez, é resgatado na produção do texto escolar

Por meio de um processo de aceitação do enunciado do texto-fonte, as redações escolares recuperam o dito por O. Henry, mas não conseguem resgatar os implícitos de $O$ presente dos magos. Há falta de um olhar analítico que desça à imanência discursiva e busque lá mecanismos de produção do sentido. Diante disso, o sujeito-aluno é levado a fazer escolhas na produção de seus enunciados porque está determinado a um dizer movido pelas próprias coerções de um gênero, no contexto escolar. No que concerne a tais coerções sofridas pelo aluno leitor, Discini (2005a, p. 34) constata que "o sujeito firma-se, entretanto, como um modo de ser no mundo pela maneira como responde às coerções". Nesse sentido, para essa autora, "as coerções consolidam convenções para o dizer e como dizer" (DISCINI, 2005a, p. 38). Em nosso caso, esse sujeito é o próprio aluno que responde às coerções da instituição escola.

Podemos, portanto, dizer que o texto interpretativo escolar configura-se como submisso ao status quo. A temática fica, pois, subordinada à temática do texto-fonte para leitura, uma vez que a categoria da aproximação ao conto dá sustentação ao texto interpretativo. Dissemos aproximação para expressar a dependência que a produção interpretativa escolar possui em relação ao texto-base para leitura.

Dessa forma, o tipo de organização dos textos que compõem a totalidade escolar já demonstra por si só um estilo, se pensarmos em estilo como recorrência. O texto interpretativo escolar mantém uma relação de "existência" em função de outro texto, por meio de um resumo parafrástico: uma relação quase simbiótica. Ressalvamos, contudo, que o texto interpretativo tem que existir em função de outro texto, mas não necessariamentecomo resumo parafrástico, paráfrase esta apresentada como comentários parafrásticos pelos nossos sujeitos intérpretes. Conforme Britto (2001, p. 125), “a maior ou menor presença de cada um desses procedimentos depende damaneira como o estudante recruta e opera com os vários recursos lingüísticos de que dispõe, bem como do tema, modalidade redacional, do momento e do lugar em que escreve e da imagem do interlocutor". Britto sugere o modo como o enunciador-aluno ativa e maneja os conhecimentos que estruturam a forma de expressão e a do conteúdo no momento da discursivização de seu texto. No corpus 
analisado, o sujeito-leitor é pouco presente: é mais um sujeito mediador entre o conto literário e o sujeito pressuposto às próprias redações escolares.

Por meio da relação estabelecida entre os conjuntos textuais, devemos ter em mente que pelo menos duas maneiras distintas de organizar textos interpretativos podem ocorrer. Como queremos chegar à demarcação do estilo de um grupo de usuários da língua (enunciadores no final do processo de escolarização de uma escola específica) em práticas sócio-discursivas escolares, constatamos um estilo dos textos interpretativos escolares examinados. Esse estilo é depreendido e definido a partir do agrupamento dos sujeitos que compartilham características discursivas comuns, constituindo, assim, um tipo de norma interpretativa na escola. Nesse sentido, poderíamos encontrar um texto que se respaldasse em um aparato teórico-metodológico para poder lançar um olhar analítico ao texto-fonte para leitura, ou um texto que parafraseasse o texto-fonte e utilizasse opiniões pautadas em uma ideologia bem marcada.

Teríamos então dois estilos próprios: o estilo do sujeito analista, que faz uso de uma metodologia de análise baseada em uma metalinguagem e o estilo do sujeito parafraseador, que apenas reproduz as estruturas do texto-matriz para leitura. Esses dois estilos nos conduziriam a observar o ideal enunciativo exigido pela instituição escolar e o tipo de prática enunciativa revelada por nosso corpus. Se tivéssemos a concretização desses dois modos de dizer, nas produções escolares examinadas, diríamos a preponderância do éthos A (estilo A) ou do éthos B (estilo B). Não é o que acontece, pois temos apenas o estilo B.

Interessante notar que, apesar do ideal enunciativo pregado pela escola ser direcionado a um fazer analítico, nosso corpus revela um distanciamento desse propósito investigativo. Cria-se um antagonismo, uma incompatibilidade entre o tipo de modelo de análise estabelecido teoricamente pelo Discurso Pedagógico e o modelo observado pelos textos que constituem nossa totalidade examinada.

Apesar do ideal visado de produção escolar, a existência de um discurso escolar interpretativo, vinculado a um sujeito parafraseador, demonstra claramente a situação de ensino de leitura e interpretação nas escolas brasileiras, uma vez que a Escola $\left(\mathrm{S}_{1}\right)$ leva o Aluno $\left(\mathrm{S}_{2}\right)$ a adquirir um objeto valor (saber e um poder ler/interpretar) por meio de uma doação de um objeto modal que se tematiza como recordar, resumir e parafrasear. Assim, o modo de organização das estruturas do Percurso Gerativo do Sentido dos textos interpretativos escolares reflete a condição de um sujeito leitor e intérprete constituído pela escola ao longo dos anos escolares; uma escola que não permite ao sujeito aluno a conjunção com saberes que o leve a se tornar um sujeito analista de fato. Ao escrever um texto opinativo, o aluno parafraseia o já dito, sem a tensão com a polissemia, 
respondendo a coerções no modo de dizer já consolidadas pelo ensino escolar. Entra em cena o primado de uma competência discursiva que nos permite observar os modos de articulação do discurso e da capacidade dos sujeitos escolares de interpretar e produzir enunciados. Os estudantes parafraseiam as estruturas do texto-fonte, já que estão orientados pela competência escolar que prevê um poder e um saber fazer segundo o outro, o texto-fonte. A ordem deve ser mantida de acordo com a cena fundadora.

A tarefa de construção textual empreendida pelos estudantes justifica-se, ainda, se pensarmos que o ato de resumir representa também uma escolha que não é neutra, uma vez que durante o movimento sintetizador, ênfase é dada a alguns fatos, ao passo que outros são deixados de lado. O estilo dos textos interpretativos está assentado justamente no processo de captação resumidora, que pressupõe escolher de um texto-fonte determinados valores do nível fundamental, percursos narrativos, objetos de valor, atores, tempos, espaços, temas e figuras e reestruturar todos esses elementos em um texto "analítico" escrito. Como afirma Eco (2004, p. 85), "uma vez atualizado o nível discursivo, o leitor está em condições de sintetizar trechos inteiros de discurso mediante uma série de macroproposições". Nesse sentido, Fuchs (1994, p. 10) vai dizer: "Le résumeur construit à partir de l'interprétation qu'il a de $\mathrm{T}$ un nouveau texte T' plus court, aux fins de transmettre à l'interlocuteur les informations 'essentielles' contenues dans $T^{\prime 38}$. Portanto, por meio de "sumários", isto é, resumos parafrásticos do conto, os alunos leitores deram ênfase a determinadas instâncias do Percurso Gerativo do Sentido emdetrimento a outras.

É pelo processo de captação do texto-fonte para leitura, captação esta observada em todos os níveis de geração do sentido, que podemos demonstrar como um sistema de atração presente no texto norteia a leitura e a interpretação, uma vez que o leitor precisa orientar-se no textofonte para poder realizar sua produção como enunciador de um texto interpretativo. Dessa maneira, as produções escritas aqui reunidas não se estruturam ao acaso, pois as recorrências do olhar receptivo dos leitores escolares "convergem para pontos nodais" (RIFFATERRE, 1973, p. 50) do texto de O. Henry. Entendemos, entretanto, os "pontos nodais" como uma estrutura de pontos nodais do conto de O. Henry recuperada pelos textos dos alunos. Essa convergência de procedimentos cria uma homogeneidade no olhar receptivo que se articula mais uma vez ao Discurso Pedagógico. Esse discurso prega uma uniformização de respostas e mostra a perspectiva de olhar único aos objetos semióticos.

Nessa direção, no fazer-parafrástico dos alunos há uma constante na seleção dos recursos a ser parafraseados. A invariância observada nas redações escolares converge a pontos que

\footnotetext{
38 O resumidor constrói a partir da interpretação que el e tem de T um novo texto T' mais curto, a fim de transmitir
} ao interlocutor as informações "essenciais" constidas em T (Tradução nossa). 
foram observados pelos leitores no texto-matriz para leitura. A paráfrase se baseou, portanto, em pontos de estímulo do texto-base norteadores da interpretação. Esses pontos nos direcionam a parcelas de recorrências significativas nas produções escritas dos alunos, o que nos mostra que determinados aspectos da estruturação interna do conto foram privilegiados em detrimento a outros. Os leitores analistas enfatizam, então, valores que são ressaltados pelo próprio ato de parafrasear, valores que todos os leitores/receptores compartilham. Os enunciadores dos textos interpretativos fazem, dessa maneira, uma captação seletiva reconstrutiva que aponta para estruturas do texto-matriz e demonstram, assim, uma preferência na seleção de conteúdos parafraseados.

Les choix effectués par le sujet lors de la reformulation du contenu sont évidemment fonction de l'ensemble des paramètres constitutifs de l'activité discursive: ils dépendent de l'objectif poursuivi par le sujet reformulant (selon le type de tâche langagière dans laquelle il est engagé), de ses connaissances du monde, des contraintes d'ordre situationnel (selon la représentation qu'il a de la situation d'énonciation du T-source et de sa propre situation de reformulation: visée de son interlocuteur, image de lui-même), ainsi que, en dernière instance, de préférences subjectives (Fuchs, 1994, p. 32)

Dessa forma, nossos alunos leitores e intérpretes são conduzidos por formações ideológicas que os direcionam a discursivizar seu mundo, por meio de temas e figuras, mas de tal forma peculiar, que determinam seu modo próprio de presença no mundo. Ainda, na esteira de Parret (1988, p. 227), podemos considerar a paráfrase como um discurso "reconstrutivo que implica subjetivação ao pressupor uma estrutura existente sobre a qual o sujeito se projeta".

Nesse sentido, as recorrências de estruturas parafraseadas presentes nos textos dos alunos nos direcionam para efeitos de sentido que fazem com que a paráfrase interpretativa seja uma atividade de constituição discursiva. Há, portanto, pelo enunciador escolar uma produção do texto em paráfrases interpretativas segundo o seu nível de leitura e sua implicação no processo de leitura reconstrutiva. $\mathrm{O}$ parafraseamento apresentado nas redações escolares constitui um julgamento de identificação em que o sujeito se esforça em um ato de reconhecimento. Tal ato é uma performance

39 As escolhas efetuadas pelo sujeito no momento da reformulação do conteúdo estão evidentemente em função do conjunto dos parâmetros constitutivos da atividade discursiva: elas dependem do objetivo buscado pelo sujeito que reformula (segundo o tipo de tarefa linguageira na qual ele está envolvido), de seus conhecimentos do mundo, coerções de ordem situacional (segundo a representação que ele tem da situação de enunciação do T-fonte e de sua própria situação de reformulação: imagem de seu interlocutor, imagem dele mesmo), como, em última instância, de suas preferências subjetivas (Tradução nossa). 
que aciona todos os parâmetros de competências do leitor, que passa a ser enunciador do texto que comenta: o conto-fonte. Dessa forma, esse julgamento é reconhecível no produto, pela reconstrução do ato produtor. (PARRET, 1988)

Esse modo de parafrasear textos literários, característico do texto interpretativo escolar, direciona nas produções escolares a predominância da figuratividade, isto é, a constituição de textos tipicamente figurativos pautados em termos concretos, em detrimento do caráter mais abstrato e temático exigido pela interpretação. A necessária vinculação do texto interpretativo ao literário imprime esse traço de coerção figurativa aos textos dos sujeitos alunos intérpretes. Por isso, para nós, o texto interpretativo escolar é gerado a partir do encaixamento das características provenientes do texto literário, o conto de O. Henry, em que a figuratividade impera, e das características do texto interpretativo padrão, uma vez que "um mesmo texto encontra-se geralmente na intersecção de múltiplos gêneros" (MAINGUENEAU, 1997, p. 37).

A presença dessa figuratividade nos textos escolares nos faz mais uma vez retornar ao sujeito-enunciador dessas produções escritas. Dessaforma, definir o estatuto desse enunciador escolar reporta a um leitor ingênuo, que reproduz o percurso figurativo do texto-fonte. Um enunciador-leitor que funda uma crença no texto literário para leitura, rendendo-se à figuratividade daquele. Um enunciador que, ao discursivizar sua análise, não traça um trajeto de interpretação, que parte da estrutura superficial, passando pela intermediáriae chegando à estrutura profunda dos textos em um movimento crescentede abstrações. Um enunciador que não sabe que todo texto requer dele uma capacidade de (re) engendrar, como leitores, os temas disseminados ao longo do texto-base e englobá-los dentro de um tema geral que sintetize de maneira ampla todo o conjunto do conto-matriz.

\subsection{O éthos do leitor escolar}

Os dados analisados encaminhama afirmação de que as recorrências do olhar receptivo dos leitores configuram um éthos do texto interpretativo escolar, éthos este depreendido pelas contingências da performance de leitura. O que é relevante, neste trabalho não éencontrar o estilo individual de um aluno-enunciador e, por conseguinte, um éthos individual, mas depreender uma imagem de enunciador da totalidade discursiva examinada, que se ancora em um gênero do discurso 
escolar. Tal imagem de sujeito se constrói pouco a pouco ao longo do discurso, ao apresentar uma identidade como resultado do conjunto de determinações semânticaspresentes nos textos interpretativos.

Tendo como objetivo depreender a imagem do leitor como intérprete de um texto literário, delinearemos o éthos do leitor escolar, tomado em relação de co-enunciação com o do conto de O. Henry. Temos um éthos erigido pela escolha feita em relação a de um gênero - texto interpretativo. A partir de um estilo parafraseador, tal sujeito se comprova nos textos analíticos como orientado pela ideologia do senso comum, fundamentada por um sistema ordenado de idéias ou representações, que supõe o acabamento e a transparência do sentido nas relações discursivas. Em relação ao discurso do senso comum, Discini (2005a, p. 284) afirma que:

O discurso do senso comum, modalizado por um crer poder ser, um crer dever ser, um crer querer ser segundo valores tidos como inquestionáveis, constitui bom exemplo para a cristalização de temas e figuras que fundamentam sistemas de preconceitos. Sustentado pelo princípio de que a realidade existe, tal qual é, uma realidade, portanto, sem contradições e mantida afastada da relação entre o ser e o parecer, o discurso do senso comum sedimenta, por meio da certeza, tematizações e figurativizações que, ao recortar o mundo, fazem parecer universal a verdade construída.

De acordo com Chauí (1984, p. 87) “a ideologia nasce para fazer com que os homens creiam que suas vidas são o que são em decorrência da ação de certas entidades que existem em si e por si e às quais é legítimo e legal que se submetam”. Os alunos representam a historicidade da realidade por meio de seus textos interpretativos, produzindo e reproduzindo seu modo de existência social.

Há, a partir do exame das interpretações escolares, um éthos incompatível com a falta patêmica (passional) explicitada no texto-fonte para interpretação. Emerge dos enunciados escolares a construção de mundo por meio da crença na possibilidade de completude do indivíduo. Nesse sentido, as redações escolares distorcem a axiologia do conto de O. Henry.

Comprova-se, dessa maneira, um aligeiramento da prática de leitura, uma autoimposição da facilitação, um modo reducionista de preenchimento das reticências que compõem todo e qualquer texto. Assim é configurado o contexto escolar no enunciado de leitura, visto segundo 
uma perspectiva que examina o sujeito posto no mundo: aluno como leitor em situação escolar. Temos, então, as formações ideológicas que ditam o que pensar para o estudante de 20. Grau: pensar em um mundo dado segundo a inevitável e obrigatória harmonização das trocas sociais. Os atores dos enunciados do conto remetem ao sujeito sempre em falta. Esse sujeito é renegado pela ideologia que repugna a falta, seja amorosa, seja de outros tipos, que é a ideologia das redações escolares.

O éthos do texto de leitura escolar apresenta-se segundo um testemunho de um tempo (século XXI) e de um espaço (instituição escolar) que viabiliza um aparato simbólico segundo o qual o homem não-quer, não-pode, não-sabe conviver com a falta e a dor provocada por ela. Dessa forma, por meio da emissão de um fazer-interpretativo que sanciona o fazer discursivo do enunciador do conto de O. Henry, esses leitores fazem um julgamento do fazer discursivo do escritor pelo final opinativo presente nos textos escolares. Um processo de interpretação que sanciona o fazer do texto-fonte para leitura quer pela investigação de sua estrutura interna, quer pela relação estabelecida com o macrotexto cultural.

Os comentários parafrásticos acabam por criar um universo paralelo e não colado ao do texto de O. Henry. Os alunos interpretam os valores inscritos no conto de origem de acordo com a própria visão ética, ou seja, de acordo com os valores de sua formação ideológica, condizente com as manifestações de paixões, valores, interesses e atitudes de nossa sociedade. Dessa forma, contrariamente ao conto que prega a possibilidade da existência de sujeitos disjuntos de objetos, da despossessão e da incompletude do sujeito, os leitores escolares instituem a conjunção com o objeto "amor" como forma de apresentar a eternização da completude do sujeito.

Os alunos negam, portanto, o final do conto de O. Henry, afirmando e reafirmando a única possibilidade do fazer do homem sob o mundo: um homem sempre em conjunção. Sob essa perspectiva, os leitores, sujeitos enunciadores do texto interpretativo escolar, deixam de parafrasear e passam a polemizar o texto-fonte. Há a discursivização de valores sociais assimilados por um leitor inscrito em um âmbito social que reproduz os ideais de um grupo social. Tais afirmações se comprovam pela voz presente nos finais opinativos. Nesse sentido, Discini (2005a, 33-34) diz que:

Assumir um ponto de vista é dar uma resposta ao outro, que é sempre polêmica, pois fundada em diferenças. Se não houver diferenças entre pontos de vista, não é possível definir nem um pronunciamento sobre o mundo, nem um lugar a ser ocupado no mundo. 
Assim como a autora, entendendo voz de um texto como ponto de vista, observamos nos fechos de leitura abaixo a dominação do consenso, revelando um ser que não é por si, mas que é pelos outros.

O uso do tempo presente para os verbos nos finais opinativos valida a idéia de "um tempo ilimitado, que ocorre em todos os tempos, demonstrando um mundo no lugar, estável, bem ao gosto do senso comum" (DISCINI, 2005a, p. 65). Reproduzimos a seguir alguns finais opinativos dos textos interpretativos escolares para comprovar nossas afirmações:

Foi então que Jim e Della envolvidos com o espírito Natalino que se aproximava descobriram que o que realmente importa é a intensão de agradar uns aos outros com amor e compreensão. (ANEXO B, texto 1, p. 172)

Porque o que realmente interessa para eles é o amor. (ANEXO B, texto 8, p. 175)

Mas o não importa o presente que se dá mais a sim a intençao que é dado. (ANEXO B, texto 23, p. 183)

Mas o que realmente importa, nem sempre é o presente si, mas sim a intensão, o amor, o carinho que leva a pessoa a dá-lo. (ANEXO B, texto 24, p. 184)

Isto mostra como o amor dos dois é tão grande eles abriram mão do que mais gostavam só para agradar um ao outro. (ANEXO B, texto25, p. 184)

Ainda, sobre o desfecho opinativo presente nos textos de leitura, observamos uma argumentação apoiada na consensualidade, sem o uso de demonstrações ou provas, pois os conteúdos apresentados são aceitos como válidos por consenso dentro de um espaço sócio-cultural (FIORIN, 1995).

O uso indiscriminado dos estereótipos desqualifica qualquer texto, pois dá mostras de que seu produtor preferiu reproduzir irrefletidamente opiniões prontas, 
tomadas de empréstimos, ao invés de esforçar-se por construir sua própria interpretação dos fatos que está considerando. Sujeitar-se a esquemas prontos é revelar uma percepção de mundo feita através dos olhos alheios e não dos próprios olhos (FIORIN, 1995, p. 360).

Ao invés de se pautarem pelo uso do olhar crítico de mundo sem o uso de lugares comuns, os alunos, regidos por uma determinada construção simbólica, isto é discursiva, do próprio mundo, lançam mão de fórmulas prontas em uma sujeição ao ponto de vista circulante no meio social. Se a esfera de sentido escolar, do discurso escolar, prevê um texto interpretativo que abarca o esclarecimento, a explanação ou a explicação, no caso do corpus analisado, essa esfera demonstrouse permeada de argumentos moralizantes, elaborações de expressões do senso comum e noções totalizadoras sem visão analítica (cf. FIORIN, 1995).

Chauí (1984, p. 87) diz que “a ideologia simplesmente cristaliza em 'verdades' a visão invertida do real. Seu papel também é o de fazer com que os homens creiam que tais idéias representem efetivamente a realidade". Dessa forma, o leitor escolar demonstra conformidade diante dos padrões da sociedade que ocultam a contradição. O éthos do leitor-receptor mostra-se mais contundente do que o de O. Henry, uma vez que as paixões da conformação e da não-contestação evidenciam valores consagrados. Há um éthos da estabilização, da ordem, do mundo no lugar. Os textos de interpretação dos alunos nos possibilitam, portanto, uma análise para a compreensão da performance de leitura desses sujeitos examinados do próprio texto, como lugar social dos enunciadores-leitores.

Há inscrito no conto $O$ presente dos magos, por outro lado, a imagem de um enunciatário cooperativo, com a competência para saber ler implícitos, um enunciatário (páthos) cético que incorpora o éthos cético do enunciador. $\mathrm{O}$ autor espera um sujeito que constrói de si e para si o simulacro de quem quer, deve, sabe e pode garimpar o sentido do texto e da vida para além do dado. O enunciador supõe, portanto, paixões da inquietude, desafios, frustrações e resignação, enfim, um co-enunciador que aceita a frustração.

Por fim, pensar na imagem depreendida do enunciador-leitor da totalidade de textos interpretativos escolares é ir em busca de elementos discursivos que tornam possível constatar um modo próprio de presença no mundo.Tal imagem construída discursivamente se constitui por meio de um corpo, de uma voz, de um tom de voz e de um caráter, um éthos, enfim. Questionamos agora, 
em que medida o éthos de um texto interpretativo se relaciona a um páthos inscrito no texto-matriz para leitura.

Se todo texto já comporta em si uma imagem de enunciatário prevista como construção discursiva, procuramos entender como o éthos criado pelo texto interpretativo que materializa uma leitura entretém relações com o leitor instituído pelo texto-fonte. Nessa perspectiva, após exame da totalidade discursiva, observamos que o aluno enunciador de uma produção escrita, que no nosso caso é o texto interpretativo que toma outro texto como matriz, imprimirá seu tom convicto de voz e caráter indefectível à produção textual realizada.

Dos textos enumerados de 1 a 25 depreendemos o éthos da totalidade investigada que, por sua vez, apresenta equivalências e disparidades em relação ao páthos previsto pelo texto-fonte. Nessa esteira, poderíamos distribuir os textos interpretativos escolares em duas categorias: aqueles que constroem um éthos que se assemelha às características de um páthos previsto pelo texto-fonte ou um éthos imprevisível que se distancia do páthos instituído pelo texto. Mas só encontramos a segunda categoria em nosso corpus. O leitor real cerceado pela situação escolar de produção da leitura comprova um páthos contraditório ao projetado. A imagem que O. Henry tem do leitor se distancia da imagem do leitor-enunciador dos textos interpretativos.

Nessa perspectiva, recuperando a única possibilidade entre os dois estilos de textos interpretativos observados por nós neste trabalho, ou seja, o estilo parafraseador, podemos enveredar nosso olhar para possíveis modos de relação entre éthos da totalidade escolar e o páthos previsto em um texto no ato de leitura. Por meio do estilo analista, por exemplo, todo éthos do texto interpretativo deve reconstruir o páthos previsto pelo texto-fonte em uma incorporação harmônica. Não é o caso das redações examinadas. Por outro lado, como é o caso das redações escolares, surge a possibilidade de rejeição do páthos previsto. É nessa incompatibilidade, nessa não harmonização, que queremos insistir.

\subsection{A interação entre éthos e páthos}

Após nossas reflexões a respeito do texto interpretativo escolar e de sua constituição, bem como a respeito de uma totalidade específica, que serviu de corpus para nossa análise, resta uma questão: em que medida o éthos do leitor escolar se apresenta como um éthos responsivo, que dialoga com a imagem do leitor (páthos) inscrito no texto literário? Cremos aqui estar nos limites de 
uma interação entre éthos e páthos e, mais particularmente, na confluência entre os simulacros construídos no texto com aqueles em construção no momento da leitura e interpretação.

O simulacro, ao se erigir como "imagem, construída e trocada entre enunciador e enunciatário, no processo de manipulação intersubjetiva, que fundamenta a comunicação" (DISCINI, 2003, p. 73), permite observar, pelo cotejo entre as duas totalidades textuais apresentadas neste trabalho, um espaço de apreensão de possíveis modos de construção do éthos da totalidade escolar. Devemos considerar, dessa forma, o éthos do leitor escolar como responsivo ao páthos inscrito no texto-fonte.

Para pensar em páthos, temos que retomar os estudos aristotélicos e encontrar noções preliminares fundadas nas três provas que envolvem um ato de comunicação: a primeira reside no caráter moral do orador; a segunda, nas disposições que se criam no ouvinte e a terceira, no próprio discurso, pelo que ele demonstra ou parece demonstrar. Nesse caso, fazemos refêrencia aos conceitos de éthos, páthos e lógos.

Em relação ao destinatário da comunicação, o orador, para articular seu discurso, precisa conhecer o auditório ao qual ele se dirige e, portanto, determinar o páthos ou o estado de espírito do auditório, isto é, a "disposição do sujeito para ser isto ou aquilo" (FIORIN, 2004a, p. 71). Falamos de uma imagem que o enunciador tem de seu enunciatário construída a partir daquilo que o público pensa, sente, espera, etc. Fiorin (2004a, p. 72) afirma que a imagem do enunciatário, “consubstanciada em um papel temático, tem uma dimensão cognitiva: de um lado ideológica, da ordem do saber (cogitent), de outro, da ordem do crer (opinentur); uma dimensão patêmica (sentiant) e uma dimensão perceptiva (expectent)".

A partir desses aspectos, o enunciador é capaz de dirigir seu discurso a um receptor ideal, uma vez que tais propriedades se apresentam como coerções para a construção discursiva. Dessa maneira, o enunciatário, ao encontrar características que lhe são próprias, identifica-se com elas e adere ao discurso. Se houver, então, adesão o discurso foi eficaz. Como afirma Fiorin (2004b, p. 134):

O enunciatário não adere ao discurso apenas porque ele é apresentado como um conjunto de idéias que expressam seus possíveis interesses. Ele adere, porque se identifica com um dado sujeito da enunciação, com um caráter, com um corpo, com um tom. Assim, o discurso não é apenas um conteúdo, mas também um modo de dizer, que constrói os sujeitos da enunciação. 
Até aqui, discorremos sobre a relação éthos/ páthos inscritos em um único conjunto de textos. No que concerne à nossa pesquisa, nós nos deparamos com duas totalidades discursivas, entre as quais temos a primeira (texto-base), que é necessariamente o motivo gerador da segunda (textos interpretativos). Chamamos a atenção para uma característica essencial e fundante: o éthos do enunciador do texto interpretativo entretém relações com o páthos, imagem do enunciatário incorporada à imagem do narratário do conto que lhe deuorigem.

Se páthos remete à construção modelar de um leitor, poderíamos pressupor então que um éthos de uma totalidade composta por textos interpretativos fosse compatível com a imagem de enunciatário inscrita no texto-fonte. $\mathrm{O}$ enunciador-leitor, no ato de organização de um texto interpretativo, por meio de uma enunciação particular, deveria saber e poder seguir os mesmos percursos de leitura propostos ao enunciatário. Dessa forma, o éthos construído para a totalidade interpretativa seria convergente com a imagem de leitor instituída pelo texto-fonte. Esquematicamente, podemos visualizar tal constatação pelo seguinte modelo:

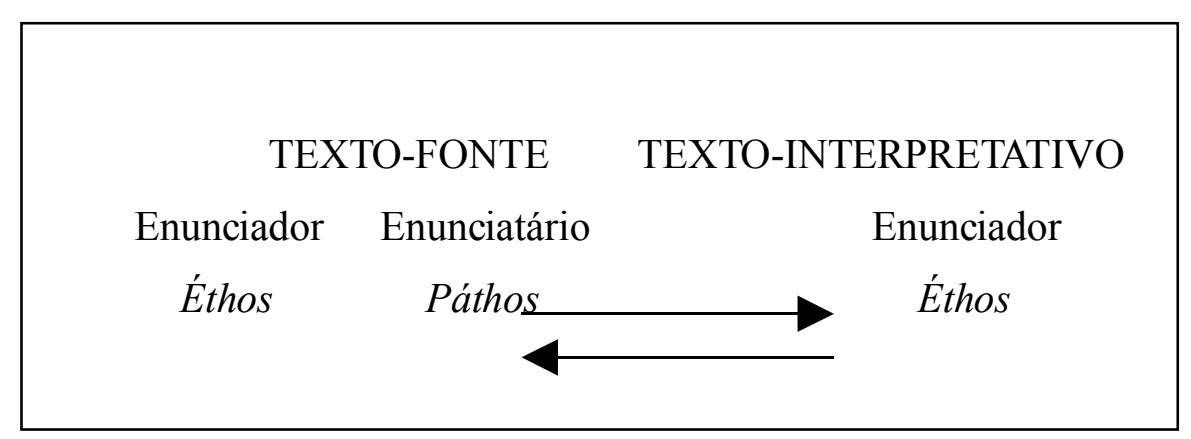

Podemos deduzir, assim, a relação éthos escolar - páthos literário, a partir da imagem do enunciador do conto (éthos); da imagem prevista do enunciatário no conto (páthos); da imagem do enunciador das redações escolares (éthos) - um éthos responsivo que responde ao páthos previsto pelo conto de O. Henry.

A partir de duas grandes vias de constituição, seria possível definir, então, uma imagem de sujeito da totalidade escolar que se funda conforme àquela projetada no interior do texto-fonte e outra não conforme àquela inscrita no interior do enunciado. Duas possibilidades de éthos surgem direcionadas a uma responsividade ao páthos em O. Henry. Podemos prever, inicialmente, essas duas maneiras possíveis de constituir o éthos do leitor e intérprete ao discursivizar sua análise tendo em vista sua relação com o páthos do texto-fonte: 
a) o éthos em conformidade com o páthos: é a imagem daquele que crê nas mesmas proposições previstas para o enunciatário e adere a elas. Um éthos de um leitor que adere ao páthos ao aceitar e compartilhar suas crenças;

b) o éthos em não conformidade com o páthos: imagem de um leitor que se distancia do feixe de expectativas previsto.

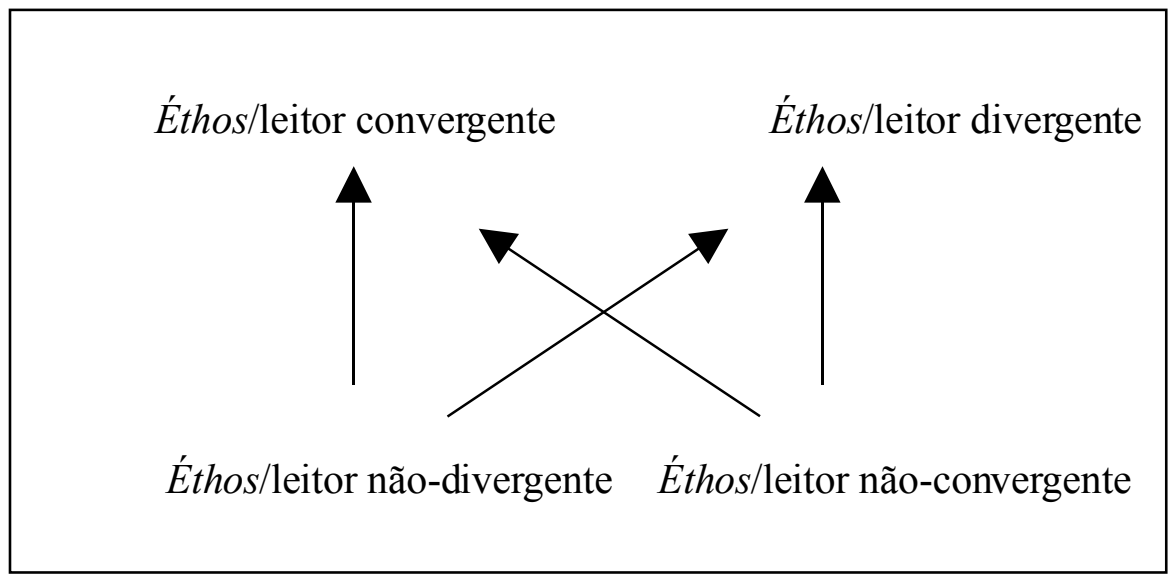

O quadrado proposto mostra, dessa maneira, possibilidades de observar a existência das relações entre éthos e páthos fundados em dois pólos: um de aceitação e outro de rejeição. O éthos responsivo de uma produção interpretativa resvala, dessa maneira, em um imaginário passional criado pelo enunciador do texto para leitura. O sujeito que lê, determinado por seus quereres, saberes, poderes e deveres, apresentará uma inclinação para aderir a certos valores inscritos no texto e, guiado por atrações e repulsões, incorporará ou não o modo de ser pretendido para o enunciatário. Fica compreensível, portanto, que a construção do éthos do leitor escolar entretenha relações com o simulacro de leitor fundado no texto para leitura: de menor ou maior conformidade ou, ainda, de não conformidade. A harmonização, éthos da totalidade escolar e páthos da totalidade literária, depende, assim, das seleções executadas que orientam a apreensão do sentido e dos valores.

A construção de um éthos interpretativo passa, assim, pelo crivo do crer, vinculado ao do saber e do poder, modalidades que compõem a competência do sujeito. $\mathrm{O}$ enunciador dos textos interpretativos, ao compartilhar as mesmas crenças que o enunciatário instituído pelo texto literário, erigiria de si uma imagem compatível com aquela do enunciatário previsto. Isso quer dizer que as mesmas axiologias culturais das quais dispõe o sujeito leitor e intérprete seriam aquelas disponibilizadas ao enunciatário, o que estabelecerianormas de leitura harmonizáveis. Teríamos uma leitura partilhada sob trocas harmônicas entre o enunciatário do texto-base e o enunciador dos textos interpretativos. Dessa forma, o olhar do enunciador das produções interpretativas seria conduzido para os mesmos sistemas de valores destinados ao enunciatário no discurso. 
Nessa esteira, notamos que os graus de saber influenciam a performance de leitura e, conseqüentemente, a construção do simulacro do enunciador do texto interpretativo. Se a competência discursiva do leitor, que se refere a um certo "saber enciclopédico", por exemplo, for paralela àquela prevista ao enunciatário do texto-matriz, a imagem que esse leitor construirá de si enquanto éthos se encaminhará para uma compatibilidade de simulacros. Por outro lado, se tal competência faltar ao leitor, a interação com o texto se tornará distorcida e as imagens tendem a se distanciar, por questões colocadas como problemas de interpretação.

Deparamo-nos assim com a "instabilidade do sentido", para resgatar uma expressão de Courtés $^{40}$. Haverá sempre um tipo de relação tensiva e flutuante entre o leitor instituído pelo texto e o leitor performático da leitura. Essa é a base de construção do éthos do produtor do texto interpretativo da totalidade escolar. Entram em questão as noções de similaridade e identidade, atreladas às de discordância e alteridade. Esse conjunto de termos que compõe um grupo de oposição mínima guia a interação entre os simulacros das duas totalidades estabelecidas nesta dissertaçao.

Não podemos esquecer que a constituição desse éthos dos textos interpretativos sofre ainda coerções do "ambiente pragmático" ao qual está vinculado. Como afirma Joseph Courtés (1998, p. 27):

Ceci dit, il y a, à ce niveau, un jeu entre l'émission et la compréhension, qui n'est pas fixé de manière stable, définitive: généralement, tout dépend en dernier lieu du contexte, de l'ambience, bref de ce que l'on applle en sémiotique l'énonciation ou, plus précisément, la "práxis énonciative $\mathrm{e}^{41}$ ".

Do cenário exposto, que envolve o ato enunciativo da leitura, a instabilidade do sentido que daí decorre faz emergir possíveis diferenciações de interpretação pela tensão estabelecida. O produtor do texto interpretativo no momento da leitura/interpretação deve poder e saber buscar uma adaptação modal, isto é, uma adaptação ao poder e ao saber propostos pelo textobase. Isso é necessário para que se possa ver aquilo que o enunciador previu para o enunciatário inscrito no texto. Dessa forma, um éthos de uma produção interpretativa compatível a um páthos do

${ }^{40}$ COURTÉS, Joseph (1998). L'énonciation comme acte sémiotique. In: Nouveaux actes sémiotiques. Vol. 58 -59. PULIM, Université de Limoges, p. 26.

${ }^{41}$ Isso dito, há, nesse nível, um jogo entre a emissão e a compreensão, que não é fixada de maneira estável, definitiva: geralmente, tudo depende em última instância do contexto, do ambiente, em suma daquilo que é chamada em semiótica de enunciação ou, mais precisamente, de "práxis enunciativa" (Tradução nossa). 
texto-fonte seria aquele que, dentre outras características, pudesse acionar as mesmas competências modais previstas ao enunciatário.

O éthos escolar, criado pelo ato de enunciar e que gera a produção interpretativa da totalidade, tangencia, dessa forma, a enunciação que constitui o páthos do texto-fonte. Temos uma enunciação segunda que possui necessariamente uma vinculação a uma enunciação primeira. Eis o processo de constituição da responsividade entre as imagens das duas totalidades. 


\section{Conclusão}

O trabalho empreendido teve como foco metodológico o cotejo entre duas totalidades textuais: a totalidade literária, composta pelos contos selecionados de O. Henry e a totalidade escolar, constituída pelos textos interpretativos erigidos a partir do conto $O$ presente dos magos. Esse caminho de pesquisa permitiu observar as relações estabelecidas entre um texto interpretativo e um texto-fonte para leitura.

Segundo os exames realizados no corpus em pauta, orientados pela teoria semiótica, a leitura e a interpretação são consideradas como feixe de mecanismos de construção de sentido fundado nos próprios textos em análise. A investigação dos procedimentos de organização das duas totalidades tornou possível, então, averiguar determinados princípios que regem processos interpretativos. $\mathrm{O}$ ato de leitura propiciou verificar como as estruturas dos textos escolares se constituíram em função das estruturas do conto literário. Essas duas interioridades, que estabelecem co-relações de identidade e alteridade, fundamentam a concepção de interpretação, vista como rearranjo do sentido.

Ao longo desta pesquisa, ao descrever e explicar o movimento perceptivo operado em função do conto literário, pudemos averiguar o fazer seletivo do leitor da totalidade escolar, como mecanismo de aceitação ou refutação de determinadas instâncias textuais e discursivas do textobase. Dessa forma, o sujeito leitor organiza seu texto-interpretativo por meio de uma (des) e (re) construção do texto-base para leitura,", por meio de elementos que aceita ou rejeita. Tal reorganização foi descrita a partir do exame dos mecanismos de construção do sentido dos textos interpretativos escolares, feitos em relação ao conto de O. Henry.

Nesse processo de reconstrução, importante foi examinar, por intermédio da observação do fazer receptivo do sujeito escolar, a fixação do olhar desse leitor em determinadas estruturas do texto-base para leitura. Dessa forma, pudemos descrever e explicar a leitura como uma posição do sentido: a posição da apreensão do sentido, analisável e passível de descrição nos próprios textos interpretativos escolares. 
$\mathrm{O}$ ato de redução das estruturas do texto de O. Henry, que proporcionou a construção do texto interpretativo, explicita o olhar do leitor que se circunscreveu à aparência textual, sem perceber, na imanência discursiva, mecanismos de construção de sentido. Os textos dos alunos não apresentam, assim, abstrações necessárias para percorrer os níveis de construção do texto. O modo de recuperação dos componentes de estruturação textual do conto O presente dos magos, legitima, então, o perfil do leitor da totalidade escolar: um leitor que, sendo detentor de uma competência própria para leitura, permanece no nível figurativo do texto-fonte, sem perceber, entretanto, as implicações ideológicas que cada figura e que o enlace das figuras supõe.

Dessa forma, o saber oferecido pela escola se materializa nos textos dos alunos por meio das marcas de estruturação textual, bem como por meio das marcas que expressam certo estar no mundo (do leitor escolar). Tais marcas ficam evidenciadas pelo modo próprio de o aluno jungir o conteúdo com a expressão, nos textos de sua autoria. A totalidade escolar posta sob exame proporciona, então, observar o "saber ler e interpretar" de um sujeito que, ao longo do percurso escolar, adquire competências específicas de uma escola que doa como objeto-valor um certo modo de interpretação construído em relação ao próprio mundo.

A leitura feita pelos alunos foi examinada na sua narratividade subjacente e descrita como a performance de um sujeito, cuja competência é construída tanto pelo poder/saber apresentados no texto-fonte, como pelo poder/saber pressupostos à situação de comunicação correspondente ao próprio ato de ler. No caso da totalidade escolar, foi possível depreender dos textos um leitor que faz a ponte entre discursos e gêneros diferentes: quanto ao texto-fonte, pertencente ao discurso literário, o leitor escolar trabalhou com o gênero conto; no contexto do ato de leitura, o leitor escolar teve sua competência e performance orientadas segundo a situação permeada pelo discurso didático.

O estudo dos textos interpretativos demonstrou as relações que as coerções próprias a um gênero escolar entretêm com a organização interna das produções textuais, componentes da totalidade escolar em questão. Nesse sentido, o gênero no qual nossos enunciadores escolares se ancoraram para a construção de suas interpretações, demonstra uma forma peculiar de constituição discursiva. As marcas do discurso dos alunos, disseminadas ao longo das produções interpretativas, proporcionam identificar o que os leitores escolares privilegiaram do texto literário. O sujeito do discurso da totalidade escolar selecionou, portanto, do conto $O$ presente dos magos, determinados temas para interpretar o mundo. Tanto os temas escolhidos pelo leitor escolar, como a valoração do valor depreendida dos textos escolares foram expressos de acordo com os valores ideológicos dos quais a cena enunciativa escolar se acha investida. 
Diante do exposto, podemos concluir que é possível, a partir do exame de uma recorrência no uso de estratégias discursivas da totalidade literária, depreender um éthos e um páthos. Chegamos à compreensão do ator da enunciação pressuposto ao texto-base oferecido para leitura, por meio da análise dos procedimentos de construção do próprio texto de leitura, visto em cotejo com outros contos de O. Henry. Salientamos que foi possível depreender o éthos e o páthos graças a uma análise discursiva orientada por um construto teórico, que permitiu depreender a relação enunciador/enunciatário do próprio texto; isso, por meio da observação de procedimentos de construção do sentido.

A imagem do enunciatário construída pelos textos de O. Henry apresenta um sujeito que aprecia ironias e que mantém um estado cético de espírito. O leitor deve ser capaz de reconhecer o distanciamento emocional e observar que a falta é constitutiva do homem. Essa falta que sempre reaparece nos contos de O. Henry, expõe, dessa maneira, a possibilidade de um estado existencial que faz parte da vida dos sujeitos.

Dos textos interpretativos escritos, desenvolvidos mediante proposta de interpretação do texto-fonte, pudemos depreender a imagem do enunciador da totalidade considerada dos textos escolares. Examinamos, portanto, o ator da enunciação, pressuposto à totalidade dos textos interpretativos, como um modo próprio de presença no mundo, ao reagir aos apelos do texto-fonte.

O conjunto de textos de leitura, ao apresentar comentários parafrásticos, acaba por instituir um leitor, cujo olhar cria um universo que tangencia o conto $O$ presente dos magos. A análise das duas totalidades e de suas relações proporciona observar que o leitor da totalidade escolar se dirige a concordâncias e discordâncias em relação às estruturas do texto-fonte.

O tema da falta, inscrito no conto, é rejeitado pelos leitores que perpetuam um crivo de leitura, em que não há a possibilidade da existência de sujeitos em disjunção. Funda-se um mundo, em que as desestabilizações nas relações humanas são apagadas. $\mathrm{O}$ sujeito erige de si e para si, então, uma imagem (éthos) da estabilização, permeada pelo senso comum que prega a constante necessidade de completude do ser. Pudemos observar uma conformidade de idéias, baseada no consenso cultural, na harmonia entre valores cristalizados em concordância entre os alunos leitores e intérpretes. Há uma compatibilidade de crenças, de conhecimentos, afetos e valores, explicitados na totalidade escolar. 
Foi possível averiguar, em última instância, as relações estabelecidas entre a construção do éthos do leitor escolar, inscrito na totalidade, com o éthos do enunciador e o páthos do enunciatário, erigidos a partir do narrador e narratário do conto-base. Temos, assim, uma imagem de leitor que dialoga com o páthos do texto-fonte, a partir de convergências e divergências das disposições oferecidas ao leitor do conto pelo enunciador.

Dessa maneira, um vínculo entre éthos e páthos da totalidade literária, incorporados nos papéis de narrador e naratário do conto $O$ presente dos magos, foi criado com o éthos do leitorintérprete. $\mathrm{O}$ simulacro de leitor escolar da totalidade foi erigido, então, em função das imagens projetadas no texto-fonte para leitura. Enfatizamos aqui a noção de éthos responsivo, fundada na relação entre a imagem do leitor escolar em relação com a imagem do leitor instituído por O. Henry.

A responsividade do éthos da totalidade escolar surge pela possibilidade usufruída pelo leitor de acolher ou rejeitar percursos de leitura propostos ao enunciatário do conto. Reforçamos, portanto, que a relação entre as imagens estabelecidas entre as duas totalidades, na configuração de um éthos responsivo, é dirigida pela conformidade ou não de características discursivas. $\mathrm{Na}$ performance de leitura, entram em cena componentes que guiam a interpretação e fazem com que o leitor construa uma imagem de si que se aproxima ou se distancia das características do enunciatário instituído no texto-fonte.

O leitor escolar, com competência que diverge daquela estabelecida pelo texto-fonte, não pôde nem soube compreender os implícitos do texto-fonte, tais como o emprego das ironias. Conclui-se que o leitor escolar é dado segundo o simulacro que se descola da imagem de enunciatário projetada por $\mathrm{O}$. Henry. O leitor, como feixe de expectativas, como o enunciatário do conto literário, diverge do sujeito dado em situação escolar de leitura. No cotejamento entre as duas totalidades, vimos que o leitor preencheu de maneira própria e inesperada as lacunas do conto $O$ presente dos magos, no ato interpretativo. Verificamos, assim, que o éthos do leitor escolar se apresenta como um reflexo e uma refração da imagem de leitor do texto-base para interpretação. 


\section{Referências Bibliográficas}

ALMEIDA FILHO, José Carlos Paes de (1993). Dimensões comunicativas no ensino de línguas. Campinas: Pontes.

ARISTÓTELES (2005). Arte retórica e arte poética. Trad. Antonio P. de Carvalho. Rio de Janeiro: Ediouro.

BAKHTIN, Mikhail (2003). Estética da criação verbal. Trad. Paulo Bezerra. 4a. ed., São Paulo: Martins Fontes.

BARROS, Diana Luz Pessoa de (2003). Estudos do discurso. In: FIORIN, José Luiz (org.). Introdução à lingüística. II. Princípios de análise. São Paulo, Contexto, p. 187-219.

(2001). Teoria do discurso: fundamentos semióticos. 2a . ed. São Paulo: Atual.

(1990). Paixões e apaixonados. Exame semiótico de alguns percursos. Cruzeiro semiótico. Porto: Associação Portuguesa de Semiótica, junho, 1989 - janeiro, p. 60-73.

(1985). A festa do discurso. Teoria do discurso e análise de redações de vestibulandos. Tese de livre docência. FFLCH/USP, Tomos I e II, texto xerografado.

BERTRAND, Denis (2003). Caminhos da semiótica literária. São Paulo: Edusc.

BÍBLIA SAGRADA(2002). Bíblia sagrada. Edição pastoral. São Paulo: Paulus.

BOURDIEU, Pierre (1979). La distinction. Critique sociale du jugement. Paris: Minuit.

BRASIL (1998). Secretaria de Educação do Ensino Médio. Parâmetros curriculares nacionais: ensino médio: língua portuguesa/secretaria de educação do ensino médio. Brasília: MEC/SEM.

BRITTO, Luiz P. L. (1997). Em terra de surdos-mudos (um estudo sobre as condições de produção dos textos escolares). In: GERALDI, João Wanderley (org.). O texto na sala de aula. São Paulo: Ática. 
BRONCKART, Jean-Paul (2003). Atividade de linguagem, textos e discursos: por um interacionismo sócio discursivo. Trad. Rachel Machado e Paulo Cunha. São Paulo: Educ.

CHAUÍ, Marilena (1984). O que é ideologia. 14a. Ed. São Paulo: Brasiliense.

CORACINI, Maria José R. F. (1995). Leitura: decodificação, processo discursivo...? In: $O$ jogo discursivo na aula de leitura. Língua materna e língua estrangeira. Campinas: Pontes, p. 13 -20 .

CORTINA, Arnaldo (2204). Semiótica e leitura: Os leitores de Harry Porter. In: CORTINA, Arnaldo e MARCHEZAN, Renata Coelho (orgs.). Razões e sensibilidades: A semiótica em foco. Araraquara: Laboratório Editorial/FCL/UNESP; São Paulo: Cultura Acadêmica Editora, p. 153-189.

(1994). Leitura como processo de compreensão e de interpretação. O príncipe e seus leitores. São Paulo: FFLCH/USP. Tese de doutorado.

(1988). O texto e o leitor. Um problema de interpretação. São Paulo: FFLCH/USP. Dissertação de mestrado.

COURTÉS, Joseph (1998). L'énonciation comme acte sémiotique. In: Nouveaux actes sémiotiques. Vol. 58-59. PULIM, Université de Limoges.

DISCINI, Norma (2005a). A comunicação nos textos: leitura, produção e exercícios. São Paulo: Contexto.

(2005b). HQ e charge. In: LOPES, Ivã Carlos e HERNANDES, Nilton. (orgs.). Semiótica. Objetos e práticas. São Paulo. Contexto, p. 261-283.

(2003). O estilo nos textos: histórias em quadrinhos, mídia e literatura. São Paulo: Contexto. (2002). Intertextualidade e conto maravilhoso. São Paulo: Humanitas/FFLCH/USP.

ECO, Umberto (2004). Lector in fabula: a cooperação interpretativa nos textos narrativos. $2^{\mathrm{a}}$ ed. Trad. Attílio Cancian. São Paulo: Perspectiva.

ECO, Umberto (1987). Notes sur la sémiotique de la réception. In: Actes sémiotiques - documents. IX, 81. Paris: Institut National de la Langue Française. 
EGGS, Ekkehard (2005). Ethos aristotélico, convicção e pragmática moderna. In: AMOSSY, Ruth. (org). Imagens de si no discurso. A construção do ethos. São Paulo: Contexto, p.29-56.

FERREIRA, Aurélio Buarque H. (1986). Novo dicionário da Língua Portuguesa. 2a. ed. Rio de Janeiro: Editora Nova Fronteira.

FIORIN, José Luiz (2005). Gêneros e tipos textuais. In: MARI, Hugo; Walty, Ivete; VERSIANI, Zélia (Orgs.). Ensaios sobre leitura. 1 ed. V. 1. Belo Horizonte: Editora PUCminas, p. 101-107. 69-78.

(2004a). O páthos do enunciatário. In: Alfa. Revista de lingüística. São Paulo, v. 48, nº 2, p.

(2004b). O éthos do enunciador. In: CORTINA, Arnaldo e MARCHEZAN, Renata Coelho (orgs.). Razões e sensibilidades: A semiótica em foco. Araraquara: Laboratório Editorial/FCL/UNESP. São Paulo: Cultura Acadêmica Editora, p. 117-138.

(2004c). Linguagem e ideologia. $8^{\mathrm{a}}$. ed. São Paulo: Ática.

(2003). Pragmática. In: FIORIN, José Luiz (org.). Introdução à lingüística. II. Princípios de análise. São Paulo: Contexto,p. 161-185.

(2002). Elementos de análise do discurso. 11ª. ed. São Paulo: Contexto- Edusp.

(1997). Teorias do discurso e ensino da leitura e da redação. In: GRAGOATÁ. O ensino de língua e da literatura. Revista do Instituto de Letras - Programa de Pós-Graduação. Niterói: EDUFF, $\mathrm{n}^{\circ} 2,1^{\circ}$ semestre, p. 7-27.

(1996). As astúcias da enunciação. São Paulo: Ática.

(1992). Algumas considerações sobre o medo e a vergonha. In: Cruzeiro semiótico. Porto: Associação Portuguesa de Semiótica. $\mathrm{n}^{\circ}$ 16. Porto/Portugal, p. 55-63.

FONTANILLE, Jacques (1987). Le savoir partagé. Amsterdam: Hadès-Benjamins.

FONTANILLE, Jacques e ZILBERBERG, Claude (2001). Tensão e significação. Trad. Ivã C. Lopes, Luiz Tatit, Waldir Beividas. São Paulo: Discurso Editorial: Humanitas/ FFLCH/USP.

FUCHS, Cathérine (1994). Paraphrase et énonciation. Paris: Editions OPHRYS. 
GARCIA, Enrico. C. (1996). O. Henry (William Sydney Porter). Trad. Sílvia de Salles Jatobá. Twayne Publishers, INC.

GERALDI, João Wanderley (1997a). Concepções de linguagem e ensino de português. In: (org.). O texto na sala de aula. São Paulo: Ática.

. (1997b). Prática da leitura na escola. In: GERALDI, João Wanderley (org.). O texto na sala de aula. São Paulo: Ática.

GREIMAS, Algirdas Julien (1993). Maupassant a semiótica do texto: exercícios práticos. Trad. Teresinha Oenning Michels e Carmen Lúcia Cruz Lima Gerlach. Florianópolis: Ed. Da UFSC.

(1983). Du sens II. Essais sémiotiques. Paris: Éditions du Seuil.

(1973). Semântica estrutural. São Paulo: Cultrix.

GREIMAS, Algirdas Julien e COURTÉS, Joseph ([1983]). Dicionário de semiótica. São Paulo: Cultrix.

(1986). Sémiotique. Dictionnaire raisonné de la théorie du langage. Vol. II. Paris: Hachette

HADDAD, Galit (2005).Ethos prévio e ethos discursivo: o exemplo de Romain Rolland. In: AMOSSY, Ruth. (org). Imagens de si no discurso. A construção do ethos. São Paulo: Contexto, p. 145-164.

HJELMSLEV, Louis (1975). Prolegômenos a uma teoria da linguagem. Trad. J. Teixeira Coelho Neto. São Paulo: Perspectiva.

ILARI, Rodolfo (1992). A lingüística e o ensino da língua portuguesa. $4{ }^{\text {a }}$ ed. São Paulo: Martins Fontes.

JOUVE, Vincent (2002). A leitura. Trad. Brigitte Hervot. São Paulo: Editora da UNESP.

KATO, Mary (1985). O aprendizado da leitura. $3^{\mathrm{a}}$. Ed. São Paulo: Martins Fontes.

KLEIMAN, Angela (2004a). Texto e leitor. Aspectos cognitivos da leitura. $9^{\mathrm{a}}$ Ed. Campinas: Pontes. 
KLEIMAN, Angela (2004b). Leitura: ensino e pesquisa. Campinas: Pontes.

KOCH, Ingedore G. V. (2003). Desvendando os segredos do texto. $2^{\mathrm{a}}$ ed. São Paulo: Cortez.

KOCH, Ingedore G. V. e ELIAS, Vanda. M. (2006). Ler e compreender: os sentidos do texto. São Paulo: Contexto.

LAJOLO, Marisa (1988). O texto não é pretexto. In: ZILBERMAN, Regina (org.). Leitura em crise na escola: as alternativas para o professor. Porto Alegre: MercadoAberto, p. 51- 62.

LAJOLO, Marisa e ZILBERMAN, Regina (1996). A formação da leitura no Brasil. São Paulo: Ática.

LANDOWSKI, Eric (1992). A sociedade refletida: ensaios de sociossemiótica. São Paulo: EDUC/Pontes.

LONG, Hudson (1960). O. Henry: the man and his work. New York: A. S. Barnes and Company, Inc.

LÜDKE, Menga e ANDRÉ, Marli. E. D. A. (1986). Pesquisa em educação: abordagens qualitativas. São Paulo: E. P. U.

MAINGUENEAU, Dominique (2005a). Gênese dos discursos. Trad. Sírio Possenti. Curitiba: Criar Edições.

(2005b). Ethos, cenografia e incorporação. In: AMOSSY, Ruth. (org). Imagens de si no discurso. A construção do ethos. São Paulo: Contexto, p. 69-92.

(2001a). O contexto da obra literária. São Paulo: Martins Fontes.

MAINGUENEAU, Dominique (2001b). Elementos de lingüística para o texto literário. São Paulo: Martins Fontes.

(2000). Termos-chave da Análise do Discurso. Trad. Márcio Barbosa e Maria Emília Amarante Lima Torres. Belo Horizonte: Editora UFMG.

(1996). Pragmática para o discurso literário. São Paulo: Martins Fontes. 
MARCHEZAN, Renata Coelho (2004). Semiotização do estético, estetização da semiótica. In: CORTINA, Arnaldo e MARCHEZAN, Renata Coelho (orgs.). Razões e sensibilidades: A semiótica em foco. Araraquara: Laboratório Editorial/FCL/UNESP; São Paulo: Cultura Acadêmica Editora, p. 139-152.

MARCUSCHI, Luiz. A. (1985). Leitura como processo inferencial num universo cultural-cognitivo. Leitura: teoria e prática. Porto Alegre: ALB/Mercado Aberto, 5, ano 4, junho.

NUNES, José Horta (1994). Formação do leitor brasileiro. Imaginário da leitura no Brasil colonial. Campinas: Editora da Unicamp.

O. HENRY (1988). Caminhos do destino e outros contos. Trad. Alzira Machado Kawall e José Paulo Paes. São Paulo: Ediouro.

(1995). 100 Selected stories. Great Britain: Wordsworth Editions Limited.

ORLANDI, Eni P. (2004). Interpretação: autoria, leitura e efeitos do trabalho simbólico. 4a. Ed. Campinas: pontes.

(1999). Análise do discurso. Princípios e procedimentos. Campinas: Pontes.

(1996a). Discurso e leitura. Campinas: Editora da Unicamp.

(1996b). A linguagem e seu funcionamento. As formas do discurso. $4^{\mathrm{a}}$ ed. Campinas: Pontes.

PARRET, Herman (1988). Enunciação e Pragmática. Trad. Eni P. Orlandi et. Al. Campinas: Unicamp.

POSSENTI, Sírio (2002). Os limites do Discurso. Curitiba: Criar Edições. (1993). Discurso, Estilo e Subjetividade. São Paulo: Martins Fontes.

PROPP, Vladmir (1983). Morfologia do conto. Lisboa: Veja.

RIFFATERRE, Michel (1973). Estilística estrutural. São Paulo: Cultrix. 
SANTANA JR. Silvio (2001). Reflexões sobre lingüística, comunicação e semiótica. In: AZEREDO, João Carlos. Letras e comunicação: Uma parceria no ensino de língua portuguesa. Rio de Janeiro; Vozes, p. 122-137.

SMITH, F. (1999). Leitura significativa. 3a. Ed. Porto Alegre: Artes Médicas.

TATIT, Luiz (2003). Abordagem do texto. In: FIORIN, José Luiz (org.). Introdução à lingüistica. II. Princípios de análise. São Paulo: Contexto, p. 187-209.

(2001). Análise semiótica através das letras. São Paulo: Atelier Editorial.

ZILBERMAN, Regina (1988). A leitura na escola. In: ZILBERMAN, Regina (org.). Leitura em crise na escola: as alternativas para o professor. Porto Alegre: MercadoAberto, p. 9-22. 


\section{Anexo A - Outros contos de O. Henry}

\section{Conto 1 - O quarto alugado}

A maior parte da população do distrito proletário do baixo West Side é inquieta, errante e fugaz como o próprio tempo. Sem possuir lar próprio, os habitantes dessa zona têm uma centena de lares. Pulam de quarto alugado para quarto alugado, permanentemente nômades: nômades de moradia, nômades de coração e pensamento. Cantam Lar, Doce Lar em tempo de ragtime; carregam lares e penates numa caixa de papelão; sua vinha se enrosca num chapéu de plumas; um vaso de fícus é a sua figueira.

Daí as casas desse bairro, tendo tido mil moradores, terem mil histórias a contar, na maioria tristes, por certo. Não seria mesmo de admirar andassem um ou dois fantasmas no rastro de tantos hóspedes fortuitos.

Certa tarde, depois de escurecer, um rapaz rondava por tais arruinadas mansões, tocando-lhes as campainhas. Na décima segunda, pousou a modesta maleta no degrau de entrada e limpou a poeira do chapéu e da testa. A campainha soou abafada e longíqua, em remotas e ermas profundezas.

À porta dessa décima segunda casa cuja campainha ele tocara, apareceu uma proprietária que o fez pensar num verme deletério e empanturrado, que houvesse roído todo o miolo de uma noz e agora procurasse encher a cavidade com inquilinos comestíveis.

Ele perguntou se havia quartos para alugar.

- Entre - disse a mulher. A voz vinha-lhe da garganta; e sua garganta parecia estar cheia de felpas. - O quarto dos fundos, no terceiroandar, vagou há uma semana. Quer vê-lo?

O jovem seguiu-a escada acima. Uma luz fraca, provinda de lugar determinado, atenuava a escuridão do corredor. Pisavam silenciosamente uma passadeira que o próprio tear em que fora tecida renegaria. Parecia ter-se tornado vegetal, ter-se degenerado, naquele ar malsão e sombrio, em líquen exuberante ou em musgo que se alastrara em manchas pelos degraus, e que era viscoso, ao pisar-se, como matéria orgânica. A cada volta da escada, viam-se nichos vazios na parede. Talvez, no passado, houvessem sido ornamentados com plantas que o ar fétido e corrupto matara. Ou com estátuas de santos, não sendo difícil imaginar que diabretes e demônios as houvessem arrastado pelas profundezas pagãsde algum fosso mobiliado lá embaixo.

- O quarto é esse - disse a mulher, com sua voz felpuda. - É um belo quarto. Raramente está vago. No verão passado, tive hóspedes muito finos; não deram o menor trabalho e pagaram adiantado. O banheiro fica no fundo do corredor. Sprowls e Mooney ocuparam este quarto durante três meses. Representavam num teatro de variedade. Miss B'retta Sprowls (já deve ter ouvido falar nela), oh! Esse é só o seu nome de teatro. Justamente ali, acima da cômoda, estava dependurada a certidão de casamento, num quadro. Aqui fica o gás, e, como vê, há bastante espaço para guardados. É um quarto de que todos gostam. Nunca fica muito tempo vago.

- Há muita gente de teatro que se hospeda aqui? - perguntou o rapaz.

- Uns vêm, outros vão. Boa parte dos meus inquilinos têm ligação com o palco, pois estamos num distrito teatral. E atores nunca demoram em parte alguma. Também sofro com isso. Sim, uns vêm, outros vão.

Ele ficou com o quarto, pagando uma semana antecipada. Estava cansado, disse, e tomaria posse do aposento imediatamente. Contou o dinheiro. O quarto já estava preparado, esclareceu a proprietária; tinha mesmo toalhas e água. Quando ela ia se retirando, ele formulou, pela milésima vez, a pergunta que trazia na ponta da língua:

- Uma mocinha, Miss Vashner, Miss Eloise Vashner... Lembra-se de ter tido alguém com esse nome como inquilina? Provavelmente cantava em algum número musical. Uma moça clara, 
magra, de estatura média, cabelos louro-avermelhados e com sinal escuro perto do supercílio esquerdo.

- Não, não me lembro desse nome. Essa gente de teatro troca de nome com a mesma freqüência com que troca de quartos. Uns vêm, outros vão. Não, não me recordo da que acaba de me descrever.

Não, sempre não. Cinco meses de interrogatórios incessantes e a inevitável negativa. Tanto tempo perdido durante o dia a questionar empresários, agentes, escolas e companhias; e durante a noite, a perscrutar a assistência dos teatros, desde os da primeira ordem até music-halls tão sórdidos que temia encontrar neles, aquela por quem tanto suspirava. Ele, que tanto a amara, tentava encontrá-la. Estava certo de que, desde o seu desaparecimento de casa, essa grande cidade rodeada de água e retinha em algum lugar; a cidade, porém, era como um monstruoso banco de areias movediças, a constantemente alternar suas partículas, sem nenhum alicerce, os grânulos superiores de hoje sepultados amanhã em vasa e lama.

O quarto alugado recebeu o novo hóspede com uma primeira e falsa fulguração de hospitalidade, uma acolhida febril, conturbada e superficial como o sorriso enganador de uma aventureira. O conforto ilusório se exibia nos vislumbres da mobília arruinada - o estofamento de brocado puído de um sofá e duas poltronas, o espelho alongando-se entre duas janelas, uma ou duas gravuras de moldura dourada, uma cama de metal a um canto.

O hóspede deixou-se cair, exausto, numa cadeira, enquanto o quarto, numa linguagem confusa como a de um aposento de Babel tentava falar-lhe de ocupantes anteriores.

Um tapete policrômico, como o retângulo florido de alguma ilha tropical, ali jazia circundado pelo mar encapelado de uma esteira suja. Na alegre parede encapelada, viam-se esses quadros que acompanham esse sempre lar de casa em casa: Os Amantes Hunguenotes, A Primeira Briga, O Almoço de Casamento, Psique e a Fonte. As linhas singelas e sóbrias da lareira estavam ingloriamente veladas poruma insolente cortina, impudicamente arrepanhada como as faixas do balé amazônico. Sobre o rebordo da lareira, jaziam alguns destroços solitários, rejeitados pelos náufragos do quarto, quando um vento propício os levara a maior porto: um dos dois reles vasos, retratos de artistas, um vidro de remédio, algumas cartas extraviadas de um baralho.

Assim como, um a um, os caracteres de um criptograma vão-se tornando compreensíveis, os poucos signos deixados pela procissão de hóspedes do quarto alugado iam adquirindo significado. $\mathrm{O}$ pedaço puído do tapete em frente da cômoda revelava que lindas mulheres ali se haviam demorado. As diminutas marcas de dedos na parede falavam de pequenos prisioneiros tateando uma saída para o sol e o ar livre. Uma mancha esparrinhada, como a sombra de uma bomba expulsa, marcava o lugar onde um frasco ou garrafa atirado com violência espalhara seu conteúdo sobre a parede. De viés, no espelho, fora garantujado com um diamante, em letras trêmulas, o nome Maria. Era como se sucessivos moradores do quarto se houvessem enfurecido - e dado largas às suas paixões. A mobília estava contundida e lascada; o sofá, de molas rebentadas, parecia um monstro disforme, abatido pelo ímpeto de alguma convulsão grotesca. Um cataclisma mais violento arrancara um pedaço do mármore da lareira. Cada tábua do assoalho possuía uma inclinação própria e um rangido peculiar, como se padecesse uma agonia individual e distinta. Parecia incrível que tantas malévolas injúrias houvessem sido inflingidas ao quarto por gente que durante certo tempo o considerara um lar; talvez fosse o instinto doméstico frustrado manifestando-se cegamente, a ira e o ressentimento contra falsos deuses domésticos, que lhe despertara a fúria. Só podemos varrer, enfeitar e querer bem a uma cabana que seja nossa.

O jovem locatário na poltrona deixava que tais pensamentos the desfilassem, de manso, pela mente, enquanto sons alugados e odores alugados invadiam o quarto. Ouviu, num aposento vizinho, um riso abafado, convulso e estridente; em outros, o monólogo de um ralho, o chacoalhar de dados, uma cantiga de ninar, ou um choro monótono; no andar de cima, alguém dedilhava um banjo animadamente. Portas batiam alhures; de quando em quando ouvia-se o estrépito dos trens elevados; um gato miava doridamente numa cerca de quintal. E o rapaz aspirava as emanações da 
casa: mais um sabor úmido do que um cheiro; um eflúvio frio e bolorento, como que provido de criptas subterrâneas, misturado com fétidas exalações de linóleo e madeira podre.

Então, de improviso, enquanto ele ali descansava, o quarto foi invadido por um odor forte e doce de resedá. Chegou como que numa única lufada de vento, com tal certeza, fragrância e intensidade, que quase parecia um visitante de carne e osso. Como se o houvessem chamado, o rapaz exclamou alto: - "Que é querida?" - e, erguendo-se, olhou em torno. O perfume capitoso apoderouse dele e o envolveu. O rapaz estendeu-lhe os braços, com todos os sentidos, nesse momento, confusos e mesclados. Como alguém podia ser peremptoriamente chamado por um perfume? Com certeza fora um ruído. Mas não tinha o ruído tocado e acariciado o seu ser?

- Ela esteve neste quarto - gritou ele, e dispôs-se a arrancar do cômodo uma prova dessa presença, pois estava certo de que reconheceria o mínimo objeto que houvesse pertencido a ela ou que ela houvesse tocado. De onde emanava a fragrância envolvente de resedá? O perfume que ela amara e fizera seu, de onde vinha?

$\mathrm{O}$ quarto fora arrumado descuidadamente. Na delgada aresta da cômoda estavam alojados meia dúzia de grampos - esses amigos e imperceptíveis da mulher, femininos no gênero, infinitos no modo e reservados no tempo. $\mathrm{O}$ moço os ignorou, cônscio da triunfante falta de identidade deles. Esquadrinhando as gavetas da cômoda, encontrou um lencinho esquecido, todo rasgado, que apertou contra a face. Rescendia insolentemente a heliotrópio. Atirou-o no chão. Em outra gaveta encontrou diversos botões, um programa de teatro, uma cautela de penhor, dois caramelos perdidos, um livro de interpretação de sonhos. Na última, havia uma fita de cetim preto para cabelos, que o deixou indeciso, entre quente e frio. Mas uma fita para cabelos é também um ornamento feminino impessoal e comum, que nada revela.

Ele percorreu então o aposento como um perdigueiro na pista, perscrutando as paredes, examinando de gatinhas os cantos do tapete saliente, remexendo lareira e mesas, as cortinas e os drapeados, o armário cambaio a um canto, em busca de um sinal visível, sem se aperceber de que ela estava ao lado, à volta, contra, dentro e acima dele, agarrando-se-lhe, cortejando-o, chamando-o tão pungentemente através dos seus sentidos mais refinados, que mesmo os mais grosseiros perceberam o chamado. De novo, ele respondeu em voz alta: - "Sim, querida!" - e voltou-se, de olhos esgazeados, para nada ver, pois não podia ainda discernir forma e cor e amor e braços acolhedores no perfume de resedá. Ó Deus, de onde vem esse perfume e desde quando os odores têm voz para chamar? Continuou a busca.

Explorou fendas e escaninhos, e encontrou rolhas e cigarros, que atirou longe, com desprezo passivo. Achando, porém, numa dobra de tapete, um charuto fumado até a metade, esmagou-o com o salto do sapato, praguejando ciumenta e energicamente. Peneirou o quarto de ponta a ponta. Encontrou vestígios ignóbeis e melancólicos ce muito inquilino peripatético; mas daquela a quem procurava, e que talvez ali se houvesse hospedado, e cujo espírito parecia ali pairar, nada encontrou.

Foi então que pensou naproprietária.

Fugiu do quarto assombrado e correu pela escada abaixo até uma porta sob a qual se infiltrava uma réstia de luz. Logo à sua primeira batida, a mulher apareceu. $\mathrm{O}$ moço dominou a excitação o melhor que pôde. aluguei?

- Poderia dizer-me senhora - implorou ele, - quem ocupou antes de mim o quarto que

- Sim, senhor.Vou dizer-lhe novamente. Foram os Sprowols e Mooney, como já contei. Miss B'retta Sprowls era seu nome de teatro, mas chamava-se Mrs. Mooney. Minha casa é bem conhecida pela sua respeitabilidade. A certidão de casamento estava emoldurada, pendente de um prego, por cima...

- Que espécie de senhora era Miss Sprowls; na aparência, quero dizer?

- Ora, tinha cabelos pretos, sir; era baixa e corpulenta, com um rosto engraçado. Saíram vai fazer uma semana na terça-feira. 
- E quem ocupou o quarto antes?

- Bem, houve um jovem solteiro, ligado a negócio de fretes. Saiu devendo-me uma semana. Antes dele, havia Mrs. Crowder com duas crianças, que ficou quatro meses, e, antes dela, o velho $M r$. Doyle, cujos filhos pagavam o aluguel. $M r$. Doyle ficou seis meses. Aí já tem um ano, sir e do resto não me lembro.

$\mathrm{O}$ rapaz agradeceu e voltou desanimado para o quarto. $\mathrm{O}$ aposento estava morto. Volatirizara-se a essência que lhe dera vida. Fora-se o perfume de resedá. Em seu lugar, havia agora o antigo cheiro rançoso de móveis mofados, de atmosfera confinada.

Fugira a esperança, e, com ela, a fé. Ele sentou-se e ficou a olhar o gás amarelo que sibilava. Logo se dirigiu para a cama e começou a rasgar em tiras os lençóis.Com a lâmina do canivete, introduziu-se, apertadamente, em todas as fendas à volta das janelas e da porta. Quando tudo estava bem calafetado, desligou o gás, escancarou-o novamente, e estendeu-se gratamente ao leito.

Era a noite de Mrs. McCool sair com o canecão a buscar cerveja. Ao trazê-la de volta, sentou-se com Mrs. Purdy num desses antros subterrâneos onde as senhorias costumam se reunir e onde os vermes raramente jejuam.

- Aluguei o quarto dos fundos, no terceiro, hoje à tarde - disse ela a Mrs. Purdy, atrás de um belo círculo de espuma. - Aluguei-o a um rapaz; ele já se deitou há duas horas.

- Não diga, Mrs. Purdy! - exclamou Mrs. McCool, com intensa admiração. - A senhora é um colosso para alugar quartos como esse. E contou-lhe tudo? - concluiu num murmúrio rouco, carregado de mistério.

- Quartos - disse Mrs. Purdy, com sua voz mais felpuda - são mobiliados para alugar. Não contei nada, Mrs. McCool.

- Tem toda a razão; é alugando cômodos que ganhamos a vida. Tem muito jeito para negócios, dona. Muita gente recusaria um quarto ao saber que alguém se suicidou na própria cama que ali está.

- Como diz, temos que ganhar a vida - observou Mrs. Purdy.

- É mesmo, é verdade. Faz uma semana hoje que ajudei a senhora a pôr em ordem o quarto dos fundos, no terceiro. Era uma moça tão bonita, bonita demais para se suicidar com gás! E que carinha linda tinha!

- Poderíamos dizer que era um tipo de beleza - assentiu Mrs. Purdy, com certo ar de crítica -, não fosse o sinal preto junto da sobrancelha esquerda. Mais um pouco de cerveja, Mrs. $\mathrm{McCool}$ ?

HENRY, O. Caminhos do destino e outros contos. Trad. Alzira Machado Kawall e José Paulo Paes. São Paulo: Ediouro, p. 86-91

\section{Conto 2 - The Brief Debut of Tildy}

If you do not know Bogle's Chop House and Family Restaurant it is your loss. For if you are one of the fortunate ones who dine expensively you should be interested to know how the other half consumes provisions. And if you belong to the half to whom waiters' checks are things of moment, you should know Bogle's, for there you get your money's worth--in quartity, at least.

Bogle's is situated in that highway of bourgeoisie, that boulevard of Brown Jones-andRobinson, Eighth Avenue. There are two rows of tables in the room,six in each row. On each table is a caster-stand, containing cruets of condiments and seasons. From the pepper cruet you may shake a cloud of something tasteless and melancholy, like volcanic dust. From the salt cruet you may expect nothing. Though a man should extract a sanguinary stream from the pallid turnip, yet will his prowess be balked when he comes to wrest salt from Bogle's cruets. Also upon each table stands the counterfeit of that benign sauce made "from the recipe of a nobleman in India." 
At the cashier's desk sits Bogle, cold, sordid, slow, smouldering, and takes your money. Behind a mountain of toothpicks he makes your change, files your check, and ejects at you, like a toad, a word about the weather. Beyond a corroboration of his meteorological statement you would better not venture. You are not Bogle's friend; you are a fed, transient customer, and you and he may not meet again until the blowing of Gabriel's dinner horn. So take your change and go--to the devil if you like. There you have Bogle's sentiments.

The needs of Bogle's customers were supplied by two waitresses and a Voice. One of the waitresses was named Aileen. She was tall, beautiful, lively, gracious and learned in persiflage. Her other name? There was no more necessity for another name at Bogle's than there was for fingerbowls.

The name of the other waitress was Tildy. Why do you suggest Matilda? Please listen this time--Tildy--Tildy. Tildy was dumpy, plain-faced, and too anxious to please to please. Repeat the last clause to yourself once or twice, and make the acquaintance of the duplicate infinite.

The Voice at Bogle's was invisible. It came from the kitchen, and did not shine in the way of originality. It was a heathen Voice, and contented itself with vain repetitions of exclamations emitted by the waitresses concerning food.

Will it tire you to be told again that Aileen was beautiful? Had she donned a few hundred dollars' worth of clothes and joined the Easter parade, and had you seen her, you would have hastened to say so yoursdf.

The customers at Bogle's were her slaves. Six tables full she could wait upon at once. They who were in a hurry restrained their impatience for the joy of merely gazing upon her swiftly moving, graceful figure. They who had finished eating ate more that they might continue in the light of her smiles. Every man there--and they were mostly men--tried to make his impression upon her.

Aileen could successfully exchange repartee against a dozen at once. And every smile that she sent forth lodged, like pellets from a scatter-gun, in as many hearts. And all this while she would be performing astounding feats with orders of pork and beans, pot roasts, ham-and, sausageand-the-wheats, and any quantity of things on the iron and in the pan and straight up and on the side. With all this feasting and flirting and merry exchange of wit Bogle's came mighty near being a salon, with Aileen for its Madame Recamier.

If the transients were entranced by the fascinating Aileen, the regulars were her adorers. There was much rivalry among many of the steady customers. Aileen could have had an engagement every evening. At least twice a week some one took her to a theatre or to a dance.

One stout gentleman whom she and Tildy had privately christened "The Hog" presented her with a turquoise ring. Another one known as "Fresby," who rode on the Traction Company's repair wagon, was going to give her a poodle as soon as his brother got the hauling contract in the Ninth. And the man who always ate spareribs and spinach and said he was a stock broker asked her to go to "Parsifal" with him.

"I don't know where this place is," said Aileen while talking it over with Tildy, "but the wedding-ring's got to be on before I put a stitch into a travelling dress--ain't that right? Well, I guess!"

\section{But, Tildy!}

In steaming, chattering, cabbage-scented Bogle's there was almost a heart tragedy. Tildy with the blunt nose, the hay-coloured hair, the freckled skin, the bag-o'-meal figure, had never had an admirer. Not a man followed her with his eyes when she went to and fro in the restaurant save now and then when they glared with the beast hunger for food. None of them bantered her gaily to coquettish interchanges of wit. None of them loudly "jollied" her of mornings as they did Aileen, accusing her, when the eggs were slow in coming, of late hours in the company of envied swains. No one had ever given her a turquoise ring or invited her upon a voyage to mysterious, distant "Parsifal." 
Tildy was a good waitress, and the men tolerated her. They who sat at her tables spoke to her briefly. with quotations from the bill of fare; and then raised their voices in honeyed and otherwise-flavoured accents, eloquently addressed to the fair Aileen. They writhed in their chairs to gaze around and over the impending form of Tildy, that Aileen's pulchritude might season and make ambrosia of their bacon and eggs.

And Tildy was content to be the unwooed drudge if Aileen could receive the flattery and the homage. The blunt nose was loyal to the short Grecian. She was Aileen's friend; and she was glad to see her rule hearts and wean the attention of men from smoking pot-pie and lemon meringue. But deep below our freckles and hay-coloured hair the unhandsomest of us dream of a prince or a princess, not vicarious, but coming to us alone.

There was a morning when Aileen tripped in to work with a slightly bruised eye; and Tildy's solicitude was almost enough to heal any optic.

"Fresh guy," explained Aileen, "last night as I was going home at Twenty-third and Sixth. Sashayed up, so he did, and made a break. I turned him down, cold, and he made a sneak; but followed me down to Eighteenth, and tried his hot air again. Gee! But I slapped him a good one, side of the face. Then he give me that eye. Does it look real awful, Til? I should hate that Mr. Nicholson should see it when hecomes in for his tea and toast at ten."

Tildy listened to the adventure with breathless admiration. No man had ever tried to follow her. She was safe abroad at any hour of the twenty-four. What bliss it must have been to have had a man follow one and black one's eye for love!

Among the customers at Bogle's was a young man named Seeders, who worked in a laundry office. Mr. Seeders was thin and had light hair, and appeared to have been recently roughdried and starched. He was too diffident to aspire to Aileen's notice; so he usually sat at one of Tildy's tables, where he devoted himself to silence and boiled weakfish.

One day when Mr. Seeders came in to dinner he had been drinking beer. There were only two or three customers in the restaurant. When Mr. Seeders had finished his weakfish he got up, put his arm around Tildy's waist, kissed her loudly and impudently, walked out upon the street, snapped his fingers in the direction of the laundry, and hied himself to play pennies in the slot machines at the Amusement Arcade.

For a few moments Tildy stood petrified. Then she was aware of Aileen shaking at her an arch forefinger, and saying:

"Why, Til, you naughty girl! Ain't you getting to be awful, Miss Slyboots! First thing I know you'll be stealing some of my fellows. I must keep an eye on you, my lady."

Another thing dawned upon Tildy's recovering wits. In a moment she had advanced from a hopeless, lowly admirer to be an Eve-sister of the potent Aileen. She herself was now a mancharmer, a mark for Cupid, a Sabine who must be coy when the Romans were at their banquet boards. Man had found her waist achievable and her lips desirable. The sudden and amatory Seeders had, as it were, performed for her a miraculous piece of one-day laundry work. He had taken the sackcloth of her uncomeliness, had washed, dried, starched and ironed it, and returned it to her sheer embroidered lawn--the robe of Venus herself.

The freckles on Tildy's cheeks merged into a rosy flush. Now both Circe and Psyche peeped from her brightened eyes. Not even Aileen herself had been publicly embraced and kissed in the restaurant.

Tildy could not keep the delightful secret. When trade was slack she went and stood at Bogle's desk. Her eyes were shining; she tried not to let her words sound proud and boastful.

"A gentleman insulted me to-day," she said. "He hugged me around the waist and kissed me."

"That so?" said Bogle, cracking open his business armour. "After this week you get a dollar a week more." 
At the next regular meal when Tildy set food before customers with whom she had acquaintance she said to each of them modestly, as one whose merit needed no bolstering:

"A gentleman insulted me to-day in the restaurant. He put his arm around my waist and kissed me."

The diners accepted the revelation in various ways - some incredulously, some with congratulations; others turned upon her the stream of badinage that had hitherto been directed at Aileen alone. And Tildy's heart swelled in her bosom, for she saw at last the towers of Romance rise above the horizon of the grey plain in which she had for so long travelled.

For two days Mr. Seeders came not again. During that time Tildy established herself firmly as a woman to be wooed. She bought ribbons, and arranged her hair like Aileen's, and tightened her waist two inches. She had a thrilling but delightful fear that Mr. Seeders would rush in suddenly and shoot her with a pistol. He must have loved her desperately; and impulsive lovers are always blindly jealous.

Even Aileen had not been shot at with a pistol. And then Tildy rather hoped that he would not shoot at her, for she was always loyal to Aileen; and she did not want to overshadow her friend.

At 4 o'clock on the afternoon of the third day Mr. Seeders came in. There were no customers at the tables. At the back end of the restaurant Tildy was refilling the mustard pots and Aileen was quartering pies. Mr. Seeders walked back to where they stood.

Tildy looked up and saw him, gasped, and pressed the mustard spoon against her heart. A red hair-bow was in her hair; she wore Venus's Eighth Avenue badge, the blue bead necklace with the swinging silver symbolic heart.

Mr. Seeders was flushed and embarrassed. He plunged one hand into his hip pocket and the other into a fresh pumpkin pie.

"Miss Tildy," said he, "I want to apologise for what I done the other evenin'. Tell you the truth, I was pretty well tanked up or I wouldn't of done it. I wouldn't do no lady that a-way when I was sober. So I hope, Miss Tildy, you'll accept my 'pology, and believe that I wouldn't of done it if I'd known what Iwas doin' and hadn't of been drunk." had been made.

With this handsome plea Mr. Seeders backed away, and departed, feeling that reparation

But behind the convenient screen Tildy had thrown herself flat upon a table among the butter chips and the coffee cups, and was sobbing her heart out--out and back again to the grey plain wherein travel they with blunt noses and hay-coloured hair. From her knot she had torn the red hairbow and cast it upon the floor. Seeders she despised utterly; she had but taken his kiss as that of a pioneer and prophetic prince who might have set the clocks going and the pages to running in fairyland. But the kiss had been maudlin and unmeant; the court had not stirred at the false alarm; she must forevermore remain the Sleeping Beauty.

Yet not all was lost. Aileen's arm was around her; and Tildy's red hand groped among the butter chips till it found the warm clasp of her friend's.

"Don't you fret, Til," said Aileen, who did not understand entirely. "That turnip faced little clothespin of a Seeders ain't worth it. He ain't anything of a gentleman or he wouldn't ever of apologised."

HENRY, O. 100 selected stories. Great Britain: Wordsworth Editions Limited, 1995, p. 80-85) 



\section{Conto 3 - A Service of Love}

When one loves onesArt no service seems too hard.

That is our premise. This story shall draw a conclusion from it, and show at the same time that the premise is incorrect. That will be a new thing in logic, and a feat in story-telling somewhat older than the Great Wall of China.

Joe Larrabee came out of the post-oak flats of the Middle West pulsing with a genius for pictorial art. At six he drew a picture of the town pump with a prominent citizen passing it hastily. This effort was framed and hung in the drug store window by the side of the ear of corn with an uneven number of rows. At twenty he left for New York with a flowing necktie and a capital tied up somewhat closer.

Delia Caruthers did things in six octaves so promisingly in a pine-tree village in the South that her relatives chipped in enough in her chip hat for her to go "North" and "finish." They could not see her $\mathrm{f}-$, but that is our story.

Joe and Delia met in an atelier where a number of art and music students had gathered to discuss chiaroscuro, Wagner, music, Rembrandt's works, pictures, Waldteufel, wall-paper, Chopin, and Oolong.

Joe and Delia became enamoured one of the other, or each of the other, as you please, and in a short time were married-for (see above), when one loves one's Art no service seem too hard.

Mr. and Mrs. Larrabee began housekeeping in a flat. It was a lonesome flat—something like the A sharp way down at the left-hand end of the keyboard. And they were happy; for they had their Art and they had each other. And my advice to the rich young man would be - sell all thou hast, and give it to the poor - janitor for the privilege of living in a flat with your Art and your Delia.

Flat-dwellers shall endorse my dictum that theirs is the only true happiness. If a home is happy it cannot fit too close-let the dresser collapse and become a billiard table; let the mantel turn to a rowing machine, the escritoire to a spare bedchamber, the washstand to an upright piano; let the four walls come together, if they will, so you and your Delia are between. But if home be the other kind, let it be wide and long - enter you at the Golden Gate, hang your hat on Hatteras, your cape on Cape Horn, and go out by Labrador.

Joe was painting in the class of the great Magister-;you know his fame. His fees are high; his lessons are light-his high-lights have brought him renown. Delia was studying under Rosenstock - you know his repute as a disturber of the piano keys.

They were mighty happy as long as their money lasted. So is every-but I will not be cynical. Their aims were very clear and defined. Joe was to become capable very soon of turning out pictures that old gentlemen with thin side-whiskers and thick pocket-books would sandbag one another in his studio for the privilege of buying. Delia was to become familiar and then contemptuous with Music, so that when she saw the orchestra seats and boxes unsold she could have sore throat and lobster in a private dining-room and refuse to go on the stage.

But the best, in my opinion, was the home life in the little flat - the ardent, voluble chats after the day's study; the cosy dinners and fresh, light breakfasts; the interchange of ambitionsambitions interwoven each with the other's or else inconsiderable - the mutual help and inspiration; and - overlook my artlessness - stuffed olives and cheese sandwiches at 11 p. m.

But after awhile Art flagged. It sometimes does, even if some switchman doesn't flag it. Everything going out and nothing coming in, as the vulgarians say. Money was lacking to pay Mr. Magister and Herr Rosenstock their prices. When one loves one's Art no service seems too hard. So, Delia said she must music lessons to keep the chafing dish bubbling.

For two or three days she went out canvassing for pupils. One evening she came home elated. 
"Joe, dear," she said gleefully, "I've a pupil. And, oh, the loveliest people! GeneralGeneral A. B. Pinkney's daughter-on Seventy-first Street. Such a splendid house, Joe-you ought to see the front door! Byzantine I think you would call it. And inside! Oh, Joe, I never saw anything like it before.

"My pupil is his daughter Clementina. I dearly love her already. She's a delicate thingdresses always in white; and the sweetest, simplest manners! Only eighteen years old. I'm to give three lessons a week; and, just think, Joe! \$5 a lesson. I don't mind it a bit; for when I get two or three more pupils I can resume my lessons with Herr Rosenstock. Now, smooth out that wrinkle between your brows, dear, and let's have a nice supper."

"That's all right for you, Dele," said Joe, attacking a can of peas with a carving knife and a hatchet, "but how about me? Do you think I'm going to let you hustle for wages while I philander in the regions of high art? Not by the bones of Benvenuto Cellini! I guess I can sell papers or lay cobblestones, and bring in a dollar or two."

Delia came and hung about his neck.

"Joe, dear, you are silly. You must keep on at your studies. It is not as if I had quit my music and gone to work at something else. While I teach I learn. I am always with my music. And we can live as happily as millionaires on \$15 a week. You mustn't think of leaving Mr. Magister."

"All right," said Joe, reaching for the blue scalloped vegetable dish. "But I hate for you to be giving lessons. It isn't Art. But you're a trump and a dear to do it."

"When one loves one's Art no service seems too hard," said Delia.

"Magister praised the sky in that sketch I made in the park," said Joe. "And Tinkle gave me permission to hang two of them in his window. I may sell one if the right kind of a moneyed idiot sees them."

"I'm sure you will," said Delia sweetly. "And now let's be thankful for General Pinkney and this veal roast."

During all of the next week the Larrabees had an early breakfast. Joe was enthusiastic about some morning-effect sketches he was doing in Central Park, and Delia packed him off breakfasted, coddled, praised, and kissed at seven o'clock. Art is an engaging mistress. It was most times seven o'clock when hereturned in the evening.

At the end of the week Delia, sweetly proud but languid, triumphantly tossed three fivedollar bills on the 8 by 10 (inches) centretable of the 8 by 10 (feet) flat parlour.

"Sometimes," she said, a little wearily, "Clementina tries me. I'm afrd she doesn't practise enough, and I have to tell her the same things so often. And then she always dresses entirely in white, and that does get monotonous. But General Pinkney is the dearest old man! I wish you could know him, Joe. He comes in sometimes when I am with Clementina at the piano-he is a widower, you know-and stands there pulling his white goatee. 'And how are the semiquavers and the demi-semiquavers progressing?' he always asks.

"I wish you could see the wainscoting in that drawing-room, Joe! And those Astrakhan rug portières. And Clementina has such a funny little cough. I hope she is stronger than she looks. Oh, I really am getting attached to her, she is so gentle and high bred. General Pinkney's brother was once Minister to Bolivia."

And then Joe, with the air of a Monte Cristo, drew forth a ten, a five, a two and a oneall legal tender notes - and laid them beside Delia's earnings.

"Sold that water-colour of the obelisk to a man from Peoria," he announced overwhelmingly.

"Don't joke with me," said Delia_- "not from Peoria!"

"All the way. I wish you could see him, Dele. Fat man with a woollen muffler and a quill toothpick. He saw the sketch in Tinkle's window and thought it was a windmill at first. He was game, though, and bought it anyhow. He ordered another-; an oil sketch of the Lackawanna freight depot — to take back with him. Music lessons! Oh, I guess Art is still in it." 
"I'm so glad you've kept on," said Delia heartily. "You're bound to win, dear. Thirtythree dollars! We never had so much to spend before. We'll have oysters to-night."

"And filet mignon with champignons," said Joe. "Where is the olive fork?"

On the next Saturday evening Joe reached home first. He spread his \$18 on the parlour table and washed what seemed to be a great deal of dark paint from his hands.

Half an hour later Delia arrived, her right hand tied up in a shapeless bundle of wraps and bandages.

"How is this?" asked Joe after the usual greetings.

Delia laughed, but not very joyously.

"Clementina," she explained, "insisted upon a Welsh rabbit after her lesson. She is such a queer girl. Welsh rabbits at five in the afternoon. The General was there. You should have seen him run for the chafing dish, Joe, just as if there wasn't a servant in the house. I know Clementina isn't in good health; she is so nervous. In serving the rabbit she spilled a great lot of it, boiling hot, over my hand and wrist. It hurt awfully, Joe. And the dear girl was so sorry! But General Pinkney!- -Joe, that old man nearly went distracted. He rushed downstairs and sent somebody - they said the furnace man or somebody in the basement - out to a drug store for some oil and things to bind it up with. It doesn't hurt so much now."

"What's this?" asked Joe, taking the hand tenderly and pulling at some white strands beneath the bandages.

"It's something soft," said Delia, "that had oil on it. Oh, Joe, did you sell another sketch?" She had seen the money on the table.

"Did I?" said Joe. "Just ask the man from Peoria. He got his depot to-day, and he isn't sure but he thinks he wants another parkscape and a view on the Hudson. What time this afternoon did you burn your hand, Dele?"

"Five o'clock, I think," said Dele plaintively. "The iron-I mean the rabbit came off the fire about that time. You ought to have seen General Pinkney, Joe, when-"

"Sit down here a moment, Dele," said Joe. He drew her to the couch, sat down beside her and put his arm across her shoulders.

"What have you been doing for the last two weeks, Dele?" he asked.

She braved it for a moment or two with an eye full of love and stubbornness, and murmured a phrase or two vaguely of General Pinkney; but at length down went her head and out came the truth and tears.

"I couldn't get any pupils," she confessed. "And I couldn't bear to have you give up your lessons; and I got a place ironing shirts in that big Twenty-fourth Street laundry. And I think I did very well to make up both General Pinkney and Clementina, don't you, Joe? And when a girl in the laundry set down a hot iron on my hand this afternoon I was all the way home making up that story about the Welsh rabbit. You're not angry, are you, Joe? And if I hadn't got the work you mightn't have sold your sketches to that man from Peoria."

"He wasn't from Peoria," said Joe slowly.

"Well, it doesn't matter where he was from. How clever you are, Joe-and-kiss me, Joe - and what made you ever suspect that I wasn't giving music lessons to Clementina?"

"I didn't," said Joe, "until to-night. And I wouldn't have then, only I sent up this cotton waste and oil from the engine-room this afternoon for a girl upstairs who had her hand burned with a smoothingiron. I've been firing the engine in that laundry for the last two weeks."

"And then you didn't - "

"My purchaser from Peoria," said Joe, "and General Pinkney are both creations of the same art—but you wouldn't call it either painting or music."

And then they both laughed, and Joe began:

"When one loves one's Art no service seems_-" 

loves."”

But Delia stopped him with her hand on his lips. "No," she said_- "just "When one HENRY, O. 100 selected stories. Great Britain: Wordsworth Editions Limited, 1995, p. 21-26) 


\section{Anexo B - Textos interpretativos produzidos por alunos da $3^{\text {a }}$ série do Ensino Médio a partir do conto Presentes dos magos de O. Henry.}

\section{Texto 1}

Era véspera de Natal, Della desapontada contava o único dinheiro que lhe restara, economizados uma um.

Humildes, Della e Jim, seu marido, moravam num pequeno apartamento e trabalhavam duro para se sustentar. Apesar das dificuldades, Della não se esquecera de seu marido, planejando assim the comprar algo que o fizesse feliz. Não tendo dinheiro o suficiente, Della resolve vender suas lindas "madeixas". Agora com dinheiro na mão será bem mais fácil escolher o presente. Vasculhando as lojas de ponta à ponta finalmente encontrou nada mais, nada menos que uma corrente de platina para relógio, pois eles possuíam duas grandes riquezas, uma era seus lindos cabelos, já desaparecidos e o outro era um belo relógio de ouro que Jim herdara de seus familiares.

Della foi para casa com muito receio de que seu marido passasse a não gostar mais dela por ter cortado os cabelos, mas para a sua surpresa ele não se importou e também lhe presenteou. Com suas mãos ligeiras o embrulho foi desfeito e um maravilhoso conjeunto de pentes apareceu, Della expressou grande contentamento e aproveitando o momento entregou a Jim seu presente, ao abrir Jim ficou sem ação, pois havia vendido seu relógio para comprar os pentes.

Foi então que Jim e Della envolvidos com o espírito Natalino que se aproximava descobriram que o que realmente importa é a intensão de agradar uns aos outros com amor e compreensão, dando-lhes presentes sábios, seguindo os exemplos dos sapientíssimos Reis Magos.

\section{Texto 2}

São duas pessoas que se gostam muitos e moram juntos e chegando numa data muito comemorativa, o "natal" e não querião passar o natal sem dar um presente para Jim, e Jim para Della, como eles eram pobres Della só tinha um dolar e oitenta centavos.

Della saiu nas ruas a procura de um presente para Jim mas tinha pouco dinheiro, ela encontrou uma mulher que compraria seus cabelos a coisa mais valiosa que ela tinha, ela queria muito dar um presente para Jim. Mandou cortar seus cabelos para ganhar Vinte dolar e procurará cidade em todas as lojas, então encontrou uma pulsera para o relógio de Jim.

Jim que também queria dar um presente para Della, e vendeu a pulsera que era de seu avó e comprou um par de pentes que Della queria tanto para pentear seus cabelos no final abrirão os seus presentes, Della não tinha cabelo para pentear mas Jim deixou de lado os presentes que Jim não queria ver o que ia ganhare falou:

- Asse á Costela Della vamos comemor

\section{Texto 3}

O escritor do texto relata a história de um casal muito apaixondo, onde a mulher se chama Della e o homem se chama Jim, e os dois era formavam um casal pobre. 
Era véspera de natal e Della queria muito comprar um presente para o seu marido, mas a única coisa que ela conseguiu, foi economizar um dóralar e oitenta e sete centavos mas o presente que ela procurava, era uma coisa diferente, onde ninguém pudesse ter igual, então ela resolveu vender seus lindos cabelos compridos e ondulados para conseguir um dinhera á mas, e ela conseguiu vinte dólares, e foi o preço do presente que ela comprou para Jim, era uma pulseira para seu relógio. E Jim para compra o presente de Della, teve que vender o seu lindo relógio, porque Jim também não tinha dinheiro para comprar o Presente de Della, o presente que Jim comprou foi um conjunto de pentes, que Della avia visto na vitrine de uma botique muito chique, e Della tinha comentado para Jim que tinha adorado o conjunto, então então Jim resolveu comprálo de presente para Della.

Conclusão, nem um dos dois tinha onde utiliza os seus presentes.

\section{Texto 4}

Um dólar e oitenta centavos. Era tudo. Della contou umas três vezes. Um dólara e oitenta e sete centavos. E no dia seguinte era Natal. Assim fez ela.

Não havia nada para fazer a não ser sentar-se na pequena poltrona remendada e chorar. bem pobre.

Della mora em um pequeno apartamento mobiliado por oito dólares semanais. Ela era

Della arrumou-se toda para comprar um presente para Jim, mas ela só tinha um dólar e oitenta e sete centavos. Tinha guardado centavo e centavo. Vinte dólares por semana não duram muito.

As despesas foram maiores que o previsto e sobraram apenas um dólar e oitenta e sete centavos para o presente de Jim.

Passou horas pensando em comprar algo bonito, digno de seu marido.

No momento, havia dois bens de que ela e Jim se orgulharam.

O relógio de ouro de Jim, que havia sido de seu pai e de seu avô. O outro era o belo cabelo de Della.

Ela vestiu-se e foi em direção à rua descendo as escadas.

$\mathrm{Na}$ rua havia uma tabuleta dizendo: "Madame Safranie. Cabelos de todos os tipos". arfando.

Ela chega e pergunta para a Madame: - Quer comprar meu cabelo ? Perguntou Della

- Tire o chapéu, disse a Madame.

- Vinte dólares, disse a Madame.

Della pegou rapidamente o dinheiro e foi atrás do presente de Jim. Ela procurou, procurou até que achou o presente ideal, uma bela corrente que era perfeita para o relógio de Jim.

Della chegou em casa e pensou: "Se Jim não me matar", dirá que parece uma mocinha.

Ela esperou Jim sentada à mesa com a corrente na mão. Jim chega e olha fixamente para Della. Ela foi aproximando-se e disse "cortei meu cabelo para poder comprar o seu presente, não se preocupe ele vai crescer novamente. "Eu tenho um belo presente para você." Ela abriu a mão e deu à ele o seu presente.

"Não se engane a meu respeito, nada fará com que eu deixe de te amar."

Jim tira um embrulho das costas edá a Della.

Della abre rapidamente o embrulho e vê que eram os pentes que Della sempre namava na vitrine da Brocdway.

Jim ainda não havia aberto o seu presente.

"Dê-me seu relógio", disse Della. "Quero ver como fica."

Jim sentou-se na poltrona e pôs as mãos àtras da cabeça e sorriu. 
"Vamos guardar nossos presentes. São belos demais para usar como meros presentes. "Vendi meu relógio para conseguir dinheiro para comprar os pentes. Que tal preparar as costeletas agora?

\section{Texto 5}

Era natal e Della não tinha dinheiro para compra um presente para Jim.

Saiu andando pela cidade procurando o que fazer e imaginou que a (?) solução era vender o seu cabelo para uma velha e perguntou se ela queria compra ela disse sim e deu vinte dólar pelo cabelo; Della saiu contente e foi compra um presente para Jim e Della chegando em casa feis o café e ficava perto da porta esperando seu marido, quando ele chegou ficou espantado mas seu amo não mudaria por ela te cortado o cabelo; ficaram ali e trocaram seus presentes e guadaram com muito carinho já que não irian ser utilizados, pois Della ganhou um par de pentes e não tinha mas cabelo, Jim uma coreitinha para o relógio mas também tinha disfeito do relógio.

Cada um abriu mão do que mas tinha de valor para presentear um au outro

\section{Texto 6}

A história revela um casal jovem e mora num apartamento humilde, a única coisa de valor que eles tinha era o amor, Tirando isso eles tinham um dólar e oitenta e sete centavos.

Eles dois juntos estavam economizando um a um, com isso Della contou o dinheiro três vezes o dólar e oitenta e sete centavos. Mas no dia seguinte era o natal.

Não havia nada a fazer a não ser cair na poltrona remendada e chorar.

Enquanto a dona da casa etá chorando, deu uma olhada na casa, que era um pequeno apartamento, mobiliado por oito dólares semanais. Lá na entrada, uma caixinha de correspondência não penetrava nenhumacarta e uma campainha que nenhum mortal poderia fazer soar.

Della perguntou a madame "Quer compra meu cabelo" disse a madame "eu compro cabelo" tire o chapeu que eu vou dar uma olhada nele.

Vinte dólares disse a madame; Dê-me logo disse Della.

Ela vasculhou em todas as lojas, teve uma que ela encontrou uma corrente de platina para relógio. Era digna do relógio.

Jim parou sobre a porta imóvel, seus olhos estavam fixados muito sério. Cortei meu cabelo e vendi-o.

"Della", disse vamos deixar os nosso presentes de lado e guardá-los por ora. Essa corrente de platina é para o relógio cade o relógio. Disse Jim, eu vendio o relógio para conseguir dinheiro para os pentes. Agora, que tal preparar as costeletas?

\section{Texto 7}

O texto conta a história de Della e Jim um casal pobre que morava em uma casa bem humilde que sobreviviam com apenas 8 dólares.

O Natal estava chegando e Della estava preocupada por não ter dinheiro para comprar o presente de Jim, e Jim também estava em tal situação.

$\mathrm{O}$ amor deles eram tão grande que ambos fizeram sacrificios para poder presentear um ao outro. 
Della tinha longos cabelos lindos, que cuidava deles com muito carinho mais pelo seu amado todo sacrifício valia e resolveu cortá-los e vende-los, Jim tinha um lindo relógio que era do seu avô muito valioso e também vendeu

No dia do natal Della estava preocupada com medo de Jim não gostar mais dela por ela ter cortado o cabelo mais não, ele ficou espantado sim e meio chateado pelo presente que ele havia comprado, mais mesmo assim ele entregou pra ela. Ela ficou muito feliz inicialmente mas logo bateu a tristeza, eram pentes lindos que a tempos ela paquerava na vitrine mais seu cabelo cresceria e poderia usa-los.

E para surpresa dele o presente que Della havia comprado estava relacionado co, seu relógio, era uma pulseira e ele logo teve que falar que havia vendido o relógio mais tomou conta da situação pediu para que deixassem os presentes de lado por ora e fossem curtir o Natal.

E essa é a história de duas pessoas que se sacrificaram um pelo outro pelo amor, eles são considerados como verdadeiros sabios por darem presentes no Natal mesmo com tantas dificuldades, e todos que dão presentes assim são considerados verdaddeiros sabios.

\section{$\underline{\text { Texto } 8}$} se chamava Jim.

Eu entendi que Della era uma menina muito sofrida casada com um grnade homem que

Que apesar de seus sofrimentos avia muita felicidades entre os dois.

Passavam varias necessidades era Natal Della queria por tudo comprar uma pequena lembrança ao seu amor.

Era linda igual a flor tinha cabelos longos maravilhos era tudo para seu marido.

Ela juntou dinheiro para comprar um presente a Jim más não foi o suficiente e então recebeu uma proposta de sua amiga para comprar seu cabelo não pensou duas vezes.

E aceitou, com o dinheiro ela comprou o presente a Jim.

Jim desfez de seu tesouro que eraseu relogio.

No final das contas Della deu a ele uma pulseira para seu relogio. E ele deu a ela pentes para ela pentear os cabelos.

Mas nem o cabelo nem o relogio não estava ali.

E os dois viram que os presentes não o importavam para eles.

Porque o que realmente interessa para eles é o amor.

Texto 9

A história relata um casal jovem e que mora num apartamento hulmide onde, fora o amor que eles o que eles mais tinham de valor Era um relógio de ouro de Jim que o pai de Della tinha dado a ela e o outro é o cabelo,

Então ela resolveu corta o cabelo para dar um presente ao seu marido, Então depois de corta e vender seu cabelo; ela saí as lojas para procurar um presente a altura do seu amor. Então depois de vasculhar tantas lojas ela acha um presente que lhe agrada muito era uma corrente de platina para relogio.

Então ao chegar em casa com o presente que tinha comprado com tanto carinho para seu amor. Então Jim chega em casa e vê Della com seu cabelo curto faz uma expressão facial na qual não estava prepara; mas depois das explicações de Della, ele a abraçou e a entrego o seu presente, e ela com aquela felicidade pois havia ganhado um jogo de pente que havia tanto tempo namorado, então foi sua vez de dar seu presente e ele, e olha que coisa fantastica é o destino quando ele que se tratava de uma corrente $\mathrm{p} /$ relogio ele deu risada pois havia vendido o seu relogio $\mathrm{p} /$ compra o 
presente de sua amada e ali os dois se olharam e riram pois eles intenderem que por mais que seja dificil a vida o amor deles compensava tudo

\section{Texto 10}

A história mostra, um sacrifício, que os dois fizeram um para o outro.

Della queria comprar um presente para seu marido Jim, como ela tinha apenas um dólar e oitenta e sete centavos.

Para poder comprar o presente de natal para o seu marido, Della vendeu os seus longos cabelos. E com o dinheiro que ela ganhou, comprou um presente que seu marido Jim gostará muito, era uma corrente de platina.

Jim queria também comprar um presente para Della, teve também sacrificar algo valioso para ele. O seu relógio que era so seu pai e também foi de seu avô. E gostaria de dar aqueles pentes que ela tanto sonhava.

Já na casa deles Della fica muito preocupada com a reação de Jim, por achar, que ela cortou seus cabelos, ele não achasse ela mais bonita.

E ele chega em casa, ela fica assustada pensando como ele reagiria, com os cabelos cortados.

Jim vê os cabelos cortados de Della, ela fala que vende seus cabelos.

E na hora na entrega dos presentes Della abre o presente que ganhara de Jim, e então vê os pentes que ela tanto sonhou em estar em suas mãos.

E então era vez de Jim abrir o presente e lá estava um corrente que combinasse com o seu relógio.

Mas ele não tinha mais o relógio para colocar aquela linda corrente.

Eles fizeram como os reis magos, pois eles deram presente ao menino na manjedoura. $\mathrm{E}$ isso eles ficaram sábios pois derão as coisas mais valiosas que eles tinha e a sacrificaram para dar de presente de Natal um para o outro.

\section{Texto 11}

Esse texto conta de um casal que economizava muito.

No dia de natal Della só tinha, um dólar e oitenta e sete centavos, ela perguntava para si mesmo o que vai fazer com um dólar e oitenta e sete centavos.

Della queria dar um presente para o marido mas não tinha dinheiro suficiente.

As despesas tinha sido maiores do que ela tinha calculado. Ela pensa, Jim passara muitas horas planejando comprar. algo bonito para comprar para mim. o cabelo de Della.

Havia dois bens de que ela e o marido se orgulhava muito, um era o relógio e o outro era

O cabelo de Della era muito longo, ondulado e brilhante, ele chegava de seus joelhos e quase cobria como um vestido longo.

Della com sua blusa velha, e seu chápeu marron, então Della desceu as escadas para a rua, e lá até "madame sofranie", ela tinha cabelo todos os tipos.

Subiu correndo, e chegou mervosa diante da senhora.

E perguntou?

Quer comprar meus cabelos? Perguntou Della

Eu compro cabelo; disse madame. Tirou o seu chápeu, que vou dar uma olhada nele."

Madame disse, compro por vinte dolares,

Dê-me logo, disse Della. 
Quando dela chegou em sua casa Della se agitava foi dando lugar à prudência.

Della com seu cabelo curto, parecia um escolar. Ela olhou para seu reflexos no espelho, cuidadosa e criticamente.

Ela pensava Jim vai me matar

Então Jim chegou, e Della perguntou gostou de meu cabelo, ele ficou quieto, Della falou, meu cabelo cresce rápido. Jim diga feliz natal.

Jim falou você cortou seu cabelo, cortei e vendi, disse Della, Você gosta de mim assim com o cabelo curto, não vai mudar nada. não é.

Jim acordou e abraçou sua mulher, tirou um presente e colocou sobre a mesa

Então Della abriu o presente, e olhou pára e começou a chorar, tendo o conforto do marido Della ficou feliz.

Quando Della olhou aqueles pentes, que ele gamava mas o marido, então ela deu pulos de alegria por ter ganhado um presente do seu marido.

Della ficou feliz da vida que viu que o seu marido, gosta dela com cabelos longos ou curtos. Jim ama muito sua Della porque ele não liga para seu cabelo, se esta longo ou curto.

\section{Texto 12}

Esse texto conta uma história de um casal humilde que não tinha muito o que se fazer, afinal viviam uma vida digna mas com algumas dificuldades.

Era um casal, o mulher se chama Della, e o marido Jim, dela queria compra um presente ao seu marido, mas não tinha o dinheiro, devidoas despesas, mas mesmo assim Della poupa cada centavo, economizando nos meses.

Della tinha apenas 1 dolar e oitenta e sete centavos para comprar o presente.

Della pensativa, com seus olhos lacrimados, pois se a pensar um tudo e lembrou que ela e seu marido, tinha dois bens em que o marido se orgulhava, um relógio de ouro. E o outro era o seu cabelo.

Seus cabelos era como uma cascata de águas castanhas ebrilhantes.

Então se arrumou e pos-se a andar pela escada e encontrou um cartaz, em que se dizia: compra se cabelo, então Della com o olhos pois-se a entrar e perguntou queria comprar seu cabelo.

Della vendeu seu cabelo por 20 dolares onde já tinha um total certo, para comprar o presente de seu marido.

Andou a cidade inteira embusca de um presente ideal, certamente era feito para Jim.

Era uma corrente de platina para o relógio.

Afinal era natal no outro dia, e Della não queria passar o natal sem dar um belo de um presente ao seu marido.

Então voltou para casa a esperar seu marido, ansiosa Della escuta os passos do marido ao subir as escadas, roda o trinco da porta, é Jim, ele fica imovel perto da porta, Della apavorada, vai logo se explicando, que cortou o cabelo, por que queria dar um presente a Jim, mas diz que o cabelo cresce rápido.

Jim ficou meio retardado naquele momento, afinal era um de seus bens, mas tirou um embrulho do bolso pôs sobre a mesa, e abraçou Della.

O seu presente era uns lindos pares de pentes que Della queria muito, que namorava nas vitrines.

Então Jim revela a Della que vendeu seu relógio para comprar o presente de Della,

E esse texto mostra que eles são um casal muito unido, acima de qualquer coisa, venceram juntos o que mais gostavam para fazer um ao outro feliz, naquela véspera de natal. 


\section{Texto 13}

Pelo que eu li e entendi Della era uma mulher pobre que amava seu marido Jim.

Era dia de Natal ela estava planejando muito antes em comprar um Presente p/ Jim ela queria comprar um presente fino e caro ela que dava cada sentavo que podia durante meses, mas ela tinha muitas despesas Tinha ficado maiores as contas do que ela imaginava e o que sobrou a ela foram somente um dolar e oitenta e sete centavos e com esse dinheiro não dava $\mathrm{p} /$ comprar o presente mais desejado.

Ela e o marido Tinha dois bens do qual se orgulhavam um era o relógio de Ouro de Jim que Tinha sido de seu pai e de seu avô e o outro era o cabelo de Della o cabelo dela era muito belo.

Então para conseguir comprar um presente p/ seu marido resolveu vender seu cabelo, então vendeu á uma cabeleleira por 20 dólares, então correu a cidade a procura do presente de Jim quando então entrou em uma loja e encontrou o que havia feito para Jim era uma corrente de platina p/ relógio que custava 21 dólares então á comprou, então foi para a casa ás sete horas o café estava pronto e a frigideira preparada $\mathrm{p} /$ fritar as costelas.

Então ela ficou com medo da reação de Jim achava que não iria mais gostar dela pelo seu cabelo e Jim ao chegar ficou olhando fixamente $\mathrm{p} /$ ela, então disse $\mathrm{p} /$ ele que havia cortado o cabelo porque não tinha dinheiro p/ comprar seu presente. Jim então abraçou Della e disse que não iria gostar menos dela por causa de seu cabelo então deu o presente $\mathrm{p} /$ Della que era o presente que Della não imaginava ganhar era um jogo de pentes do qual sempre que passava via na vitrine ficava namorando os pentes.

Esta história é uma lição p/ todos quer dizer que não podemos julgar, ou gostar de uma pessoa só porque ela não tem aquilo Temos que aprender que nem tudo que Temos hoje podemos Ter amanhã.

\section{Texto 14}

Era véspera de Natal, Della se sentia angustiada e chorava tinha apenas um dólar e oitenta e sete centavos, era pobre sem muito conforto, vivia em um apartamento mobiliado por oito dólares semanais no dia seguinte era Natal.

Della tinha poupado casa centavo durante meses e tinha conseguido apenas um dólar e oitenta e sete centavos, tinha planejado comprar algo valioso mas com o dinheiro que possuia seria impossível, de repente olhou no espelho e teve uma idéia dar um dos seus bens mais valioso o cabelo, rapidamente pos sua velha blusa marrom e o seu velho chapeu e descendo as escadas para rua.

Parou e olhou na tabuleta de um salão de beleza, entrou no estabelecimento perguntando se a dona do salão queria comprar seu cabelo.

A Madame aceitou, começando logo o serviço.

Duas horas se passaram, Della já vasculhava as lojas a procura de presente, encontrou por fim um presente digno de Jim, uma corrente de platina para o relógio pelo preço de de Vinte e um dólares levando em seguida os oitenta e sete centavos de troco.

Chegou em casa e tentava arrumar seu cabelo na frente do espelho.

Era sete horas, Della esperava o café, sentou na cadeira e ouviu os passos de Jim.

Quando Jim abriu a porta abatido levou um tremendo susto mudando sua expressão, depois de muito tempo Della mostrou seu lindo presente natalino a Jim, uma corrente para o relógio 
depois disso foi a vez de Jim surpreender Della dando-lhe um conjunto de pentes que ela queria a muito tempo.

Della sem se importar que estava sem seus lindos cabelos pulava alegre com grande satisfação e Jim sem o seu relógio se sentia satisfeito com o presente que ganhara, afinal era Natal época de seguir o costume dos Magos dos Orientes que presentearam Jesus sem dar conta do grande valor que estavam dando a Jesus.

Foi assim que Della e Jim fizeram venderam os bens mais valiosos da família para ver a felicidade um do outro, mesmos estando sem os seus grandes tesouros no caso o relogio e o cabelo, receberam os presentes que não teria utilidade nenhuma, com grande satisfação e harmonia valorizando o espírito natalino este é o presente de Magos do Oriente onde não se leva em conta o valor do presente nem a sua utilidade, mas sim a boa vontade de se dar o presente e de se comemorar o que é o nosso maior tesouro o Nascimento deJesus.

\section{$\underline{\text { Texto } 15}$}

O que entendi da história, é que um casal apaixonado quer na época do Natal presentear um ao outro mas as condições não estava muito boa para poderem trocar presentes.

Mas, Della ficaria muito triste se não podesse presentear seu marido, naquela época em que todos faziam festa, ela tinha consigo uma coisa que Jim amava.

Era o seu lindo cabelo, mas ela vendeu para comprar algo ao seu esposo.

E ele vendeu seu relógio que era de seu avó, para presentear Della.

$\mathrm{Na}$ historia percebemos a união de duas pessoas que se amam, que apesar de todo sofrimento e lutas, estão sempre unidos um ao outro, pois quando vão trocar os presentes, ela havia comprado uma corrente para seu relógio e ele comprado o par de pentes que ela tanto sonhava em ter, mas fazer o que se ela havia vendido o cabelo e ele o tal relógio.

Eles se uniram, mais ainda e passaram o seu natal mais feliz do que esperavam.

Isso nos mostra uma licão, por que se fosse em outros casos ele poderia ter brigado pois haviam vendido o que de mais precioso havia emseu lar.

\section{Texto 16}

A contou aconteceu nos Estados unidos com um casal muito pobre e humilde, que não tinham nenhuma econômia para presentear um ao outro na época do Natal.

Faltava um dia p/ o natal e Della só tinha um dollar e oitenta e sete centavos e para agradar seu marido decidiu então vender um lindo relógio de ouro $\mathrm{p} /$ compra um lindo presente. As horas voavam e Della vasculhava as lojas a procura do presente de Jim. Até que decidiu então comprar uma bela corrente de platina. Quando Jim chegou em casa teve uma grande surpresa. Della também tinha cortado o cabelo para vender. "Por favor, Deus, faça com que ele ainda me ache bonita."

Jim ficou muito surpreso, "cortei e vendi" você gosta de mim assim, mesmo, não é ? disse Della, Jim logo a perdoou. Jim também a presenteou-a com um par de pentes lindos que ela queria muito. E então o grito de alegria, lágrimas e soluços e o conforto do marido.

O nome do conto foi dado porque os três reis magos que inventaram a arte de dar presentes no natal. "Todos os que dão presentes, assim estão entre os mais sábios.

\section{Texto 17}


Conto de uma senhora que tinha um dolar e oitenta e sete centavos economizado um a um, por três vezes e era vespera de natal

Ela começou a chorar porque ela nao tinha o dinheiro suficiente para comprar o presente para o Jim. Ela foi ajuntando o dinheiro a meses e chegou a vinte dólares por semana e não duraram muito, e as despesas era maiores que ela imaginavam. Ela pensou que com algo fixo e caro e de prata maciça - algo que fosse digno de honra de pertencer a Jim. ela resolver vender a coisa que ele mais gostava o cabelo dela e ela ganhou "vinte dólares".

Ela revirou loja por loja para ver se achava alguma coisa que Jim gostara e depois de procurar por todas as lojas achou uma corrente de platina para o relogio, era bem simples. Ela ficou um pouco com remorso por ter cortado o cabelo que era a coisa que ele mais gostava. Jim chegou e a viu de cabelo cortado e ficou surpreso, com o que viu e depois deu um abraço com muito amor. Ele comprou um pente para ela mas ela tinha cortado o cabelo e eram pentes caros e ele vendeu o conjunto de pente para ela.

\section{Texto 18}

Eu pude notar nesse texto um relato de um casal jovên que na vespêra do Natal se deparam com a dura realidade de estarem sem dinheiro, para comprarem presentes um para o outro.

Della a muller tinha apenas alguns trocados e para presentear seu marido acabou vendendo seu maior tesouro, os longos cabelos castanhos.

Com o dinheiro da venda do cabelo e mais os "trocados" que tinha comprou uma linda pulseira, para o relógio de Jim. Relógio este que era herança dos antepassados de Jim.

Mas o marido também sem dinheiro acabou vendendo o relógio para comprar o presente de sua muller, comprou bélissimos pentes para Della.

$\mathrm{Na}$ troca dos presentes se viram na seguinte situação, o presente de Della para Jim a pulseira de relógio, relógio este que ele havia vendido para comprar o presente dela e ele deu a ela os pentes, mas ela já não tinha mais os cabelos.

Deixaram os presentes de lado e se abrasarãm e viram que o maior presente que pudessem dar um ao outro era o amor e o amor dos dois já compartilhavam.

\section{Texto 19}

Era véspera de natal e Della tinha apenas um dólar e oitenta e sete centavos. Queria muito dar um presente para seu marido Jim, porém o único dinheiro que tinha era aquela mesquinhez, resultado de suas economias.

Pensou muito e achou uma saída: vender um de seus maiores tesouros, o seu belo e longo cabelo. "Pago vinte doláres" dissera a compradora. presentear Jim.

Pronto, agora já tinha dinheiro para comprar algo que satisfazesse seu desejo de

Depois de muito procurar, encontrou o presente perfeito para seu esposo. Era uma corrente de platina para relógio, simples e sóbria.

Só quando chegou em casa percebeu o que falta de prudência e bom senso tinha-a feito fazer. Os unicos tesouros que possuíam eram seu cabelo e o relógio de Jim que fora herdado de seu pai e de seu avô.

"Jim irá me matar" pensou.

As sete horas o café estava pronto. Jim era pontual e logo chegaria.

Della dobrou a corrente em sua mão e se sentou no canto da mesa, perto da porta por onde ele sempre entrava. 
Jim chegou. Parecia abatido e muito sério.

Parou à porta, imóvel e olhou para ela fixamente.

Della foi até ele e disse 'Querido não me olhe desse jeito, pois os cabelos que cortei crescerão logo. Você não vai deixar de gostar de mim por causa disso não é?"

Jim mudou de expressão, abraçou sua esposa e disse "Não se engane ao meu respeito querida, nada faria eu gostar menos de você."

Dizendo isso tirou um embrulho do capote e entregou a ela.

Inacreditável, era os pentes que Della namorara por muito tempo, sempre os quisera.

"Obrigado Jim" disse ela. Então entregou a ele a pulseirinha de platina para o relógio.

"Querido, vamos deixar nossos presentes de natal e apenas guardá-los. São muito belos para serem usados como simples objetos. Vendi o relógio para comprar os pentes. Agora que tal tomarmos o café ?" finalizou ele.

Texto 20

O texto Presentes de Reis Magos mostra um casal de jovens humildes.

Della era uma dona de casa que tinha um dolar e oitenta e sete centavos para compra um presente para seu marido, pois era natal no dia seguinte.

Della estava desesperada, pois ela queria comprar um presente inesquecivel para seu marido. Ela morava num pequeno apartamento muito humilde e lá ia acontecer sua pequena ceia de natal.

Muito triste Della teve uma ideia, queria cortar seus longos e belos cabelos para compra uma bela corrente para o relogio de seu marido

Chegou a hora da ceia de natal, seu marido chegou, houve a troca de presentes, ela ganhou um kit de escovas para o cabelo e Jin seu marido a corrente viu o sacrificio que Della fez para comprar a corrente e ele vendeu seu precioso relogio para comprar o presente de Della.

Algumas pessoas sacrificam seus bem mais preciosos para agradar a quem amamos.

\section{Texto 21}

Um dolar e oitenta e sete centavos. Era tudo que Della tinha para comprar um presente. Para Jim. Seu amado Jim.

Della sentou-se na surrada poltrona de sua sala e pos-se a chorar, e pensar como iria comprar um presente para Jim, pois era natal.

Recontou seu dinheiro e comessou a pensar o que comprar, parou em frente ao espelho e soltou seus longos cabelos que iam até seus joelhos, pegou o dinheiro e saiu passando em frente a um salão de beleza e teve a ideia de vender seus cabelos. Vinte dolares foi tudo que seu amado cabelo renderar. Depois disso Della revirou a cidade enteira atraz do presente perfeit para Jim.

Chegando à uma loja e viu uma pulseira de relojo de platina perfeita para Jim, para ele colocar em seu relojo de ouro que tinha herdado de seu pai, Della comprou a pulseira e volteou para casa.

Chegando em casa Della arrumou seu cabelo e esperou Jim chegar. Quando Jim entrou pela porta ficou olhando fixamente para Della, que assustada perguntou a Jim o que ele achara de seu novo visual, Jim olhou para ela e disse que a ama do jeito que ela é. 
Della abriu um sorriso e pediu para Jim abrir seu presente. Jim deu seu presente para Della e ela o abriu, era um conjunto de pentes que ela namorava a muito tempo, quando Jim abriu seu presente e viu a pulseira falou para Della que tinha vendido o relojo para pagar os pentes.

Jim olhou para Della e disse: prepare costeletas para o jantar, eu guardarei seu presente e vou usa-lo mais tarde. E dela abraçou os pentes e disse: - meus cabelos crescem rapidamente.

Os reis magos eram homens sabios que deram presentes para o menino na manjedoura e deram os presentes que lhes eram importantes.

E aqui esta a historia de duas crianças tolas que sacrificaram o que lhes eram mais importantes para eles.

Todos que dão e recebem presentes como eles são sabios.

Eles são os reis magos.

\section{Texto 22}

O texto Presente de reis magos, demonstra a história de uma família pobre que Della fasia parte.

Della vinham a economizar um dinheiro, dinheiro este que não daria para comprar um presente para Jim.

Della e Jim moravam numa casa humilde um pequeno apartamento mobiliado por oito dolares.

Della e Jim tinham dois bens muito precisos Della tinha um cabelo muito bonito e Jim que tinha um relogio de ouro quefoi do seu avo e de seu pai.

Della vestiu sua blusa marrom, e seu velho chapéu marrom e se dirigiu a rua. passou por um lugar de nome Madame Safranie, lugar este que ela iria a vender seu bem tão precioso. seus cabelos. A madame com a mão sobre o cabelo da um lance de 20 dolares. Dellla sem exito algum, se desfez de seus cabelos. Após cortar o cabelo foi rapidamente comprar o presente de Jim.

Ao chegar em casa Della se preocupa com a reação de Jim.

Jim chega e ali fica imovel. com tal atitude.

Della grita com Jim achando que ele não iria gostar de sua atitude. Mas Jim se espanta

Jim também veio a se disfazer do relogio que era do seu avo, para poder comprar o jogo de pentes que Della estava namonndo há muito tempo.

Della também da um presente que Jim tambem estava a desejar uma pulseira de relogio que já não iria mais precisar já que veio a vendir.

Mas Della também não iria usar os pentes tão sedo já que vendeu o cabelo para comprar o presente de Jim.

Após esta serie de acontecimentos Jim se acha que teria que guarda os presentes por serem belas demais e prepararem logo as costelas. para seia humilde como a familia.

\section{Texto 23}

Bom, o texto começo falando em dinheiro que foi economizado um a um. Della se sentou em sua poltrona e se derramou em lágrima.

Della era muito pobre, ela tinha um pequeno apartamento, mobiliado por oito dólares semanais, e que na caixa de correspondência no penetrava nenhuma carta.

Della quando terminou de chorar passou um pó-de-arroz em seu rosto. Mas mesmo tentando se animar ela só pensava no dia seguinte que era natal que ela precisava compra um presente para Jim. 
Della teve a idéia de sacrificar seu cabelo para comprar o presente para seu marido Jim. Então, ela foi em busca do presente de Jim e acabou comprando uma corrente de platina para Relógio.

E chegou o grande dia de Natal Jim colocou seu presente: Mas o não importa o presente que se dá mais a sim a intençao que é dado.

\section{Texto 24} seu marido.

Della era uma mulher bem pobre e queria comprar um presente de natal para Jim que é

Como ela não tinha dinheiro resolveu abrir mão de uma das coisas que ela mais gostava, vendeu seu cabelo para presentear o seu querido marido.

Por outro Jim estava na mesma situação, para dar um presente para Della também teve que desfazer de uma das coisas que mais gostava, vendeu o seu relógio para comprar um belo presente par Della.

Isto mostra como o amor dos dois é tão grande eles abriram mão do que mais gostavam só para agradar um ao outro.

\section{Texto 25}

Presentes de Reis Magos é um texto que nos mostra a dificuldade de dois jovens, que fazem de tudo para agradar um ao outro.

Moram em um pequeno apartamento, mobiliado por apenas oito dólares semanais, bem pobre.

A história que ocorre na véspera de Natal, nos passa a mensagem de companheirismo, o sacrifício que as vezes passamos para agradar as pessoas que gostamos muito.

Mas, infelizmente, o sacrifício que Della fez por Jim - o de cortar o seu lindo cabelo não vale a pena; já que a corrente de platina que serviria como suporte para o belo relógio de Jim, de nada serviria; infelizmente ele havia vendido seu relógio para também agradar sua esposa.

Della ganha o presente que tanto queria, os pentes que tanto namorara na vitrine da loja; enquanto seu marido acabou com um presente que parecia ser bonito, mas de nada serviria.

Mas o que realmente importa, nem sempre é o presente si, mas sim a intensão, o amor, o carinho que leva a pessoa a dá-lo. 